\author{
UNIVERSIDADE DE SÃO PAULO \\ FACULDADE DE CIÊNCIAS FARMACÊUTICAS \\ PROGRAMA DE PÓS-GRADUAÇÃO EM FÁRMACO E MEDICAMENTOS \\ ÁREA DE PRODUÇÃO E CONTROLE FARMACÊUTICOS
}

\title{
CARACTERIZAÇÃO E ANÁLISES DO ASCORBATO DE MONOMETILSILANOTRIOL EM FORMULAÇÕES COSMÉTICAS
}

\author{
Joyce Santos Quenca Guillen
}

\author{
Dissertação \\ para obtenção de Grau de Mestre
}

Orientadora

Profa. Titular Érika Rosa Maria Kedor-Hackmann

São Paulo

2007 


\author{
UNIVERSIDADE DE SÃO PAULO \\ FACULDADE DE CIÊNCIAS FARMACÊUTICAS \\ PROGRAMA DE PÓS-GRADUAÇÃO EM FÁRMACO E MEDICAMENTOS \\ ÁREA DE PRODUÇÃO E CONTROLE FARMACÊUTICOS
}

\title{
CARACTERIZAÇÃO E ANÁLISES DO ASCORBATO DE MONOMETILSILANOTRIOL EM FORMULAÇÕES COSMÉTICAS
}

\author{
Joyce Santos Quenca Guillen
}

Dissertação para obtenção de Grau de Mestre

Orientadora

Profa. Titular Érika Rosa Maria Kedor-Hackmann

São Paulo

2007 


\section{Joyce Santos Quenca Guillen}

Caracterização e análises do ascorbato de monometilsilanotriol em formulações cosméticas

Comissão julgadora

da

Dissertação apresentada no Exame de Qualificação para obtenção do Grau de Mestre

Profa. Titular Érika Rosa Maria Kedor Hackmann

Orientador/Presidente

Profa. Dra. Telma Mary Kaneko

Profa. Dra. Lucildes Mercuri Pitta

São Paulo, 07 de dezembro de 2007. 


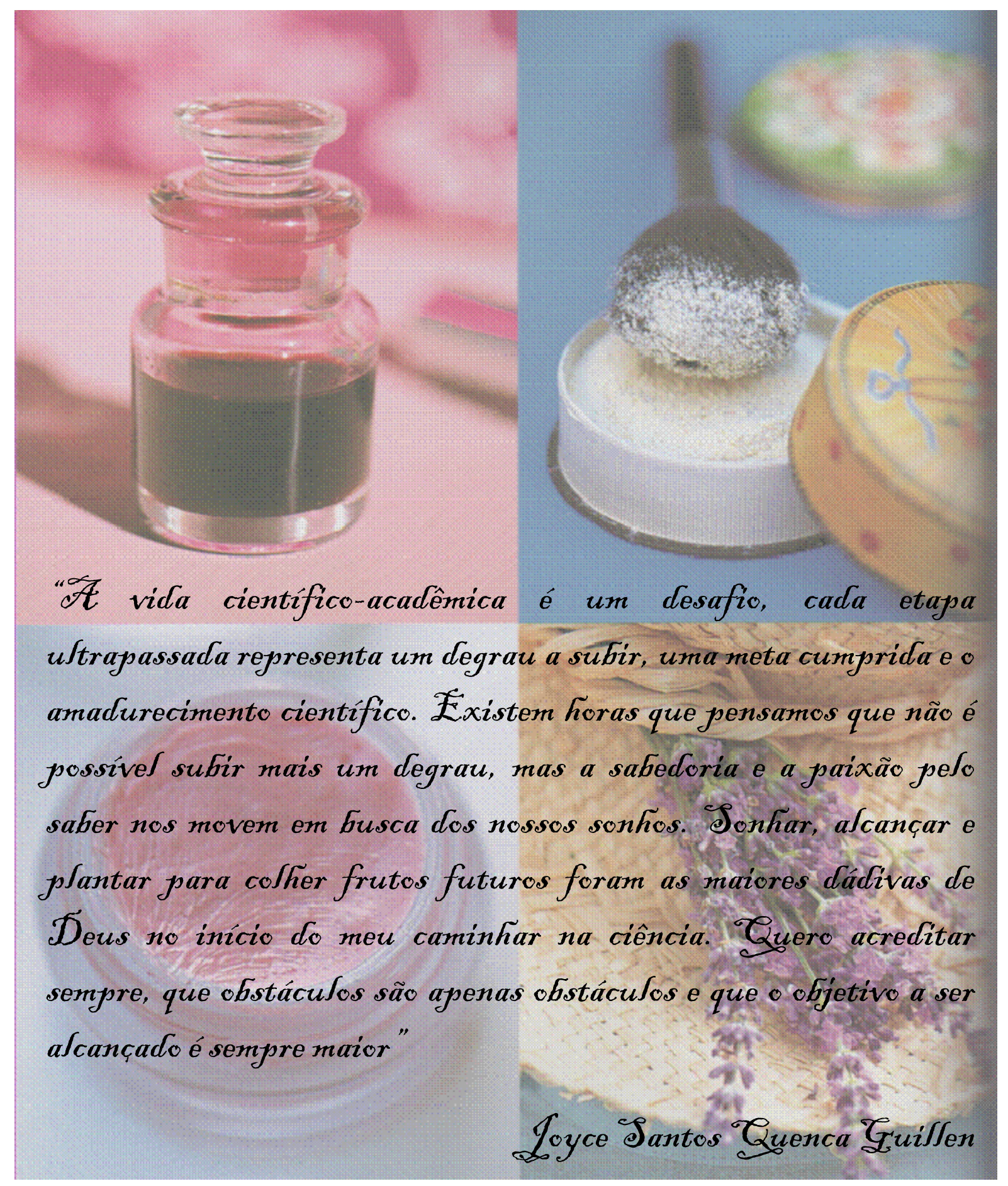




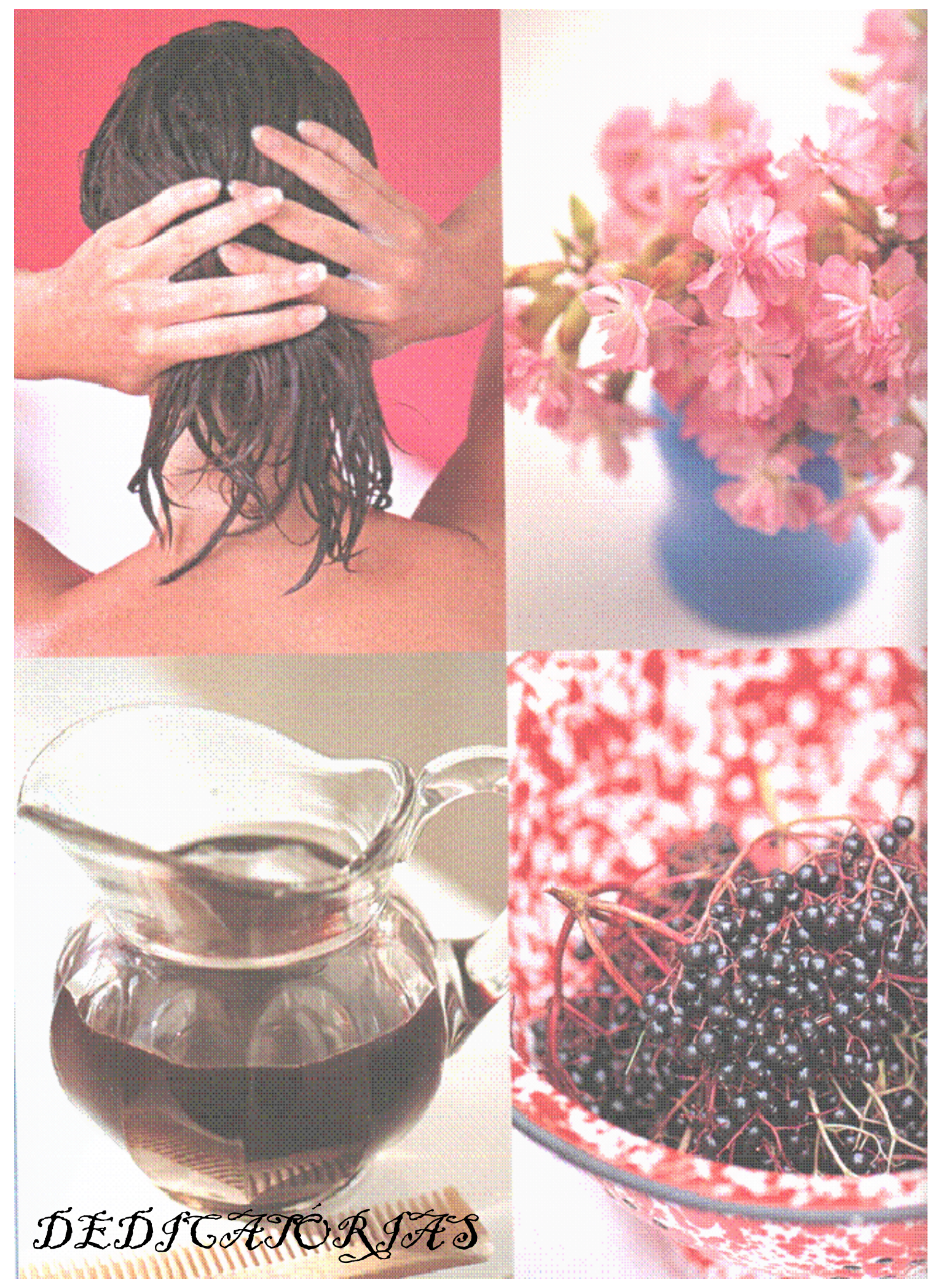




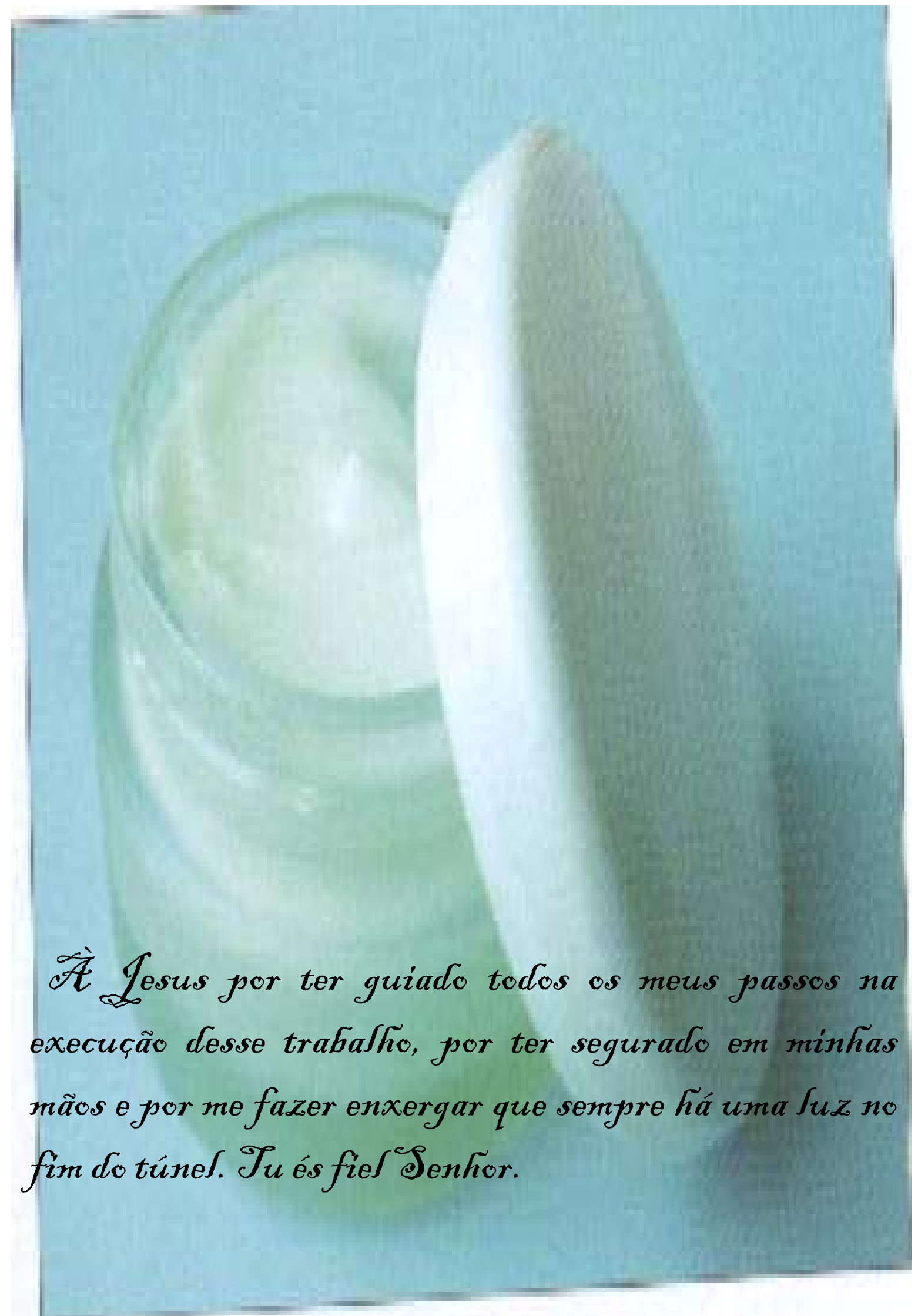




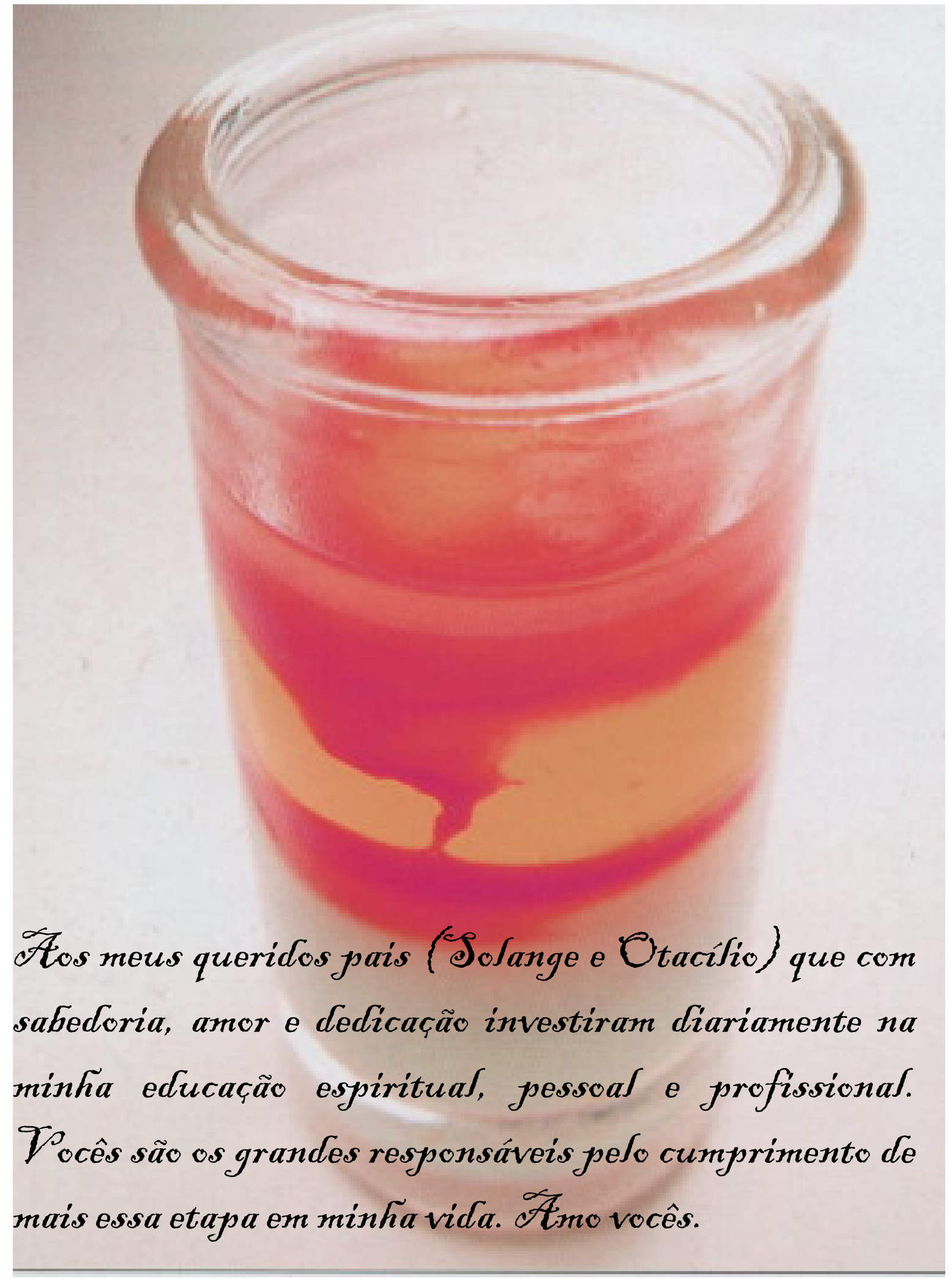




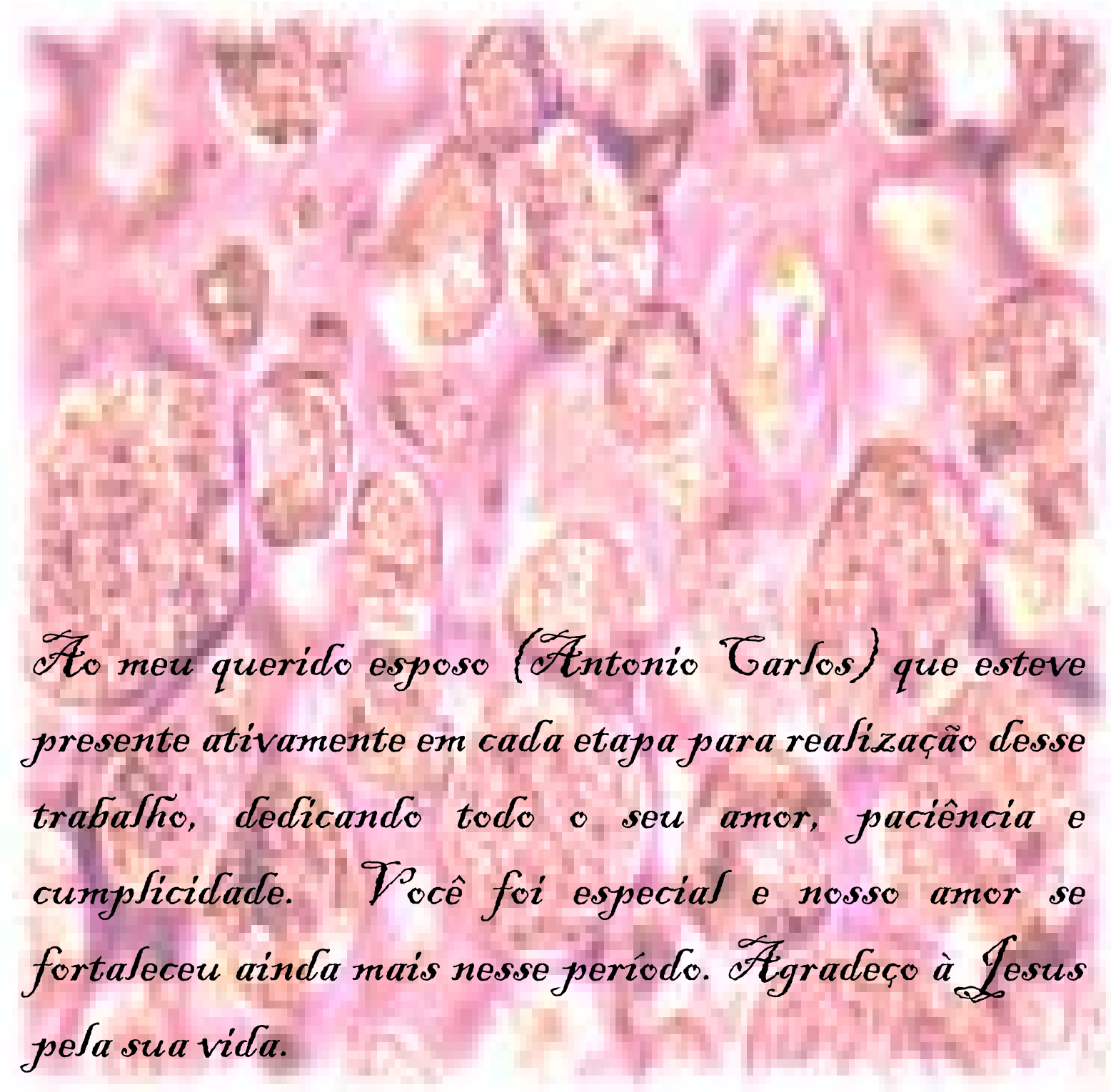




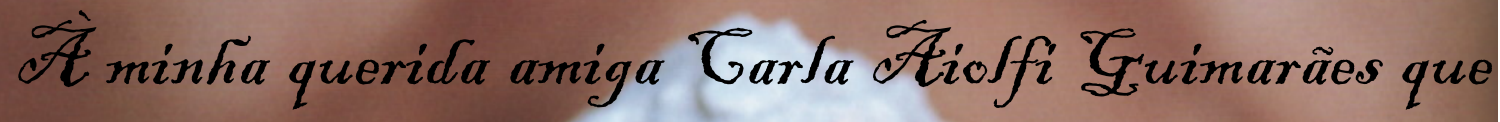
uftrapassou e venceu todos os obstáculos ao meu Sado. Amiga, sua amizade foi imprescindível para a concfusão desse trabahtho, crescemos e amadurecemos juntas. Foram tantâs as aventuras das quais você fez parte, desde black out na CGSP, madrugadas no LotJgg, viagens para Lifeirão Preto e para os congressos. Fiajamos o Drasif e o mundo pelos nossos objetivos. Fi muito especial te conhecer e que o sentior Lesus abencoesempre a nossa amizade 

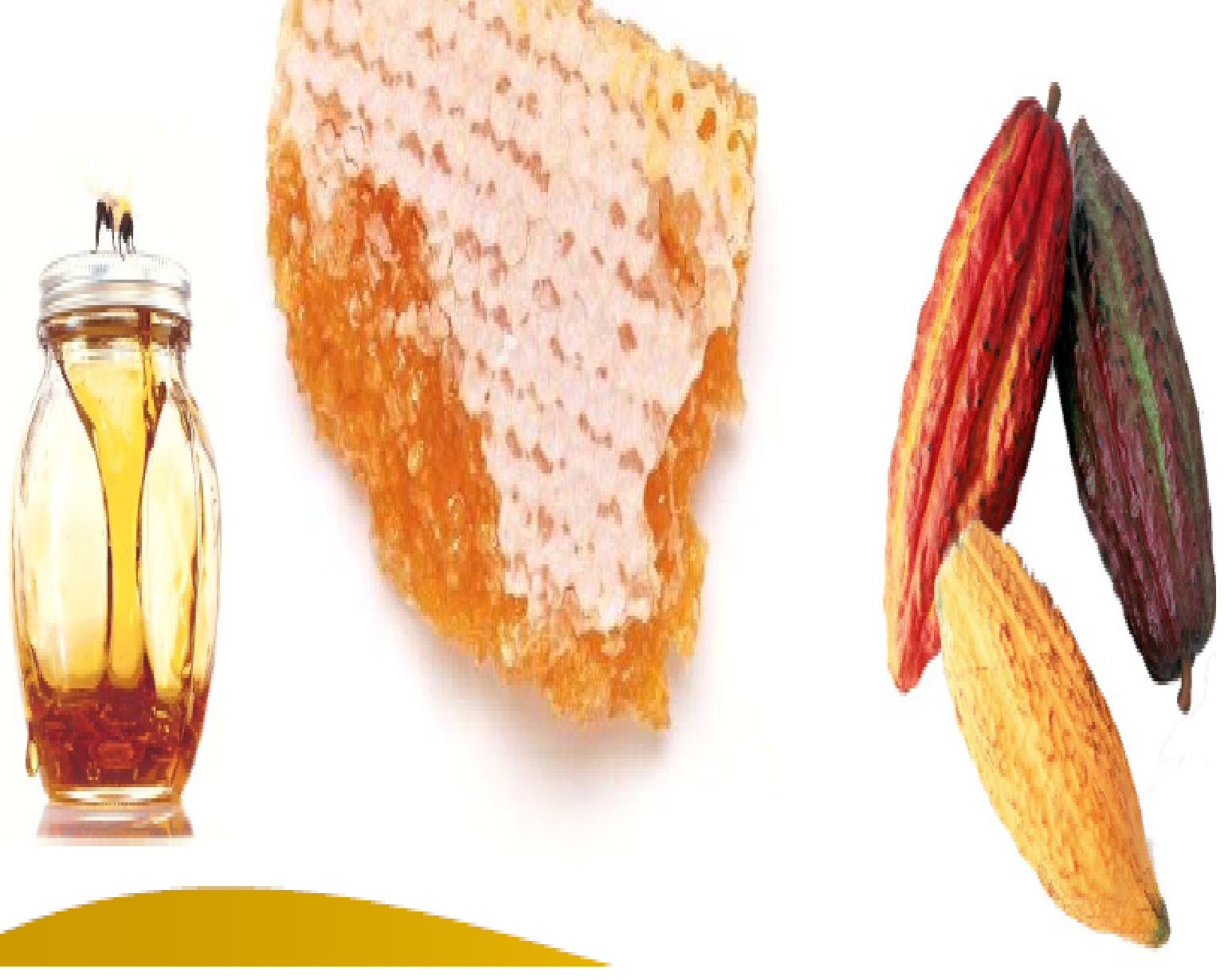

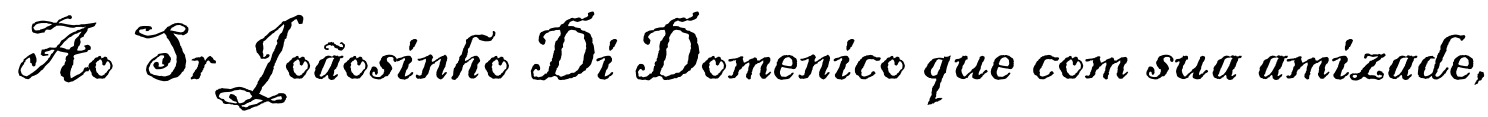
sabedoria e profundo confiecimento da área cosmética contribuiu vafiosamente para o engrandecimento cientifico desse trabalio. 


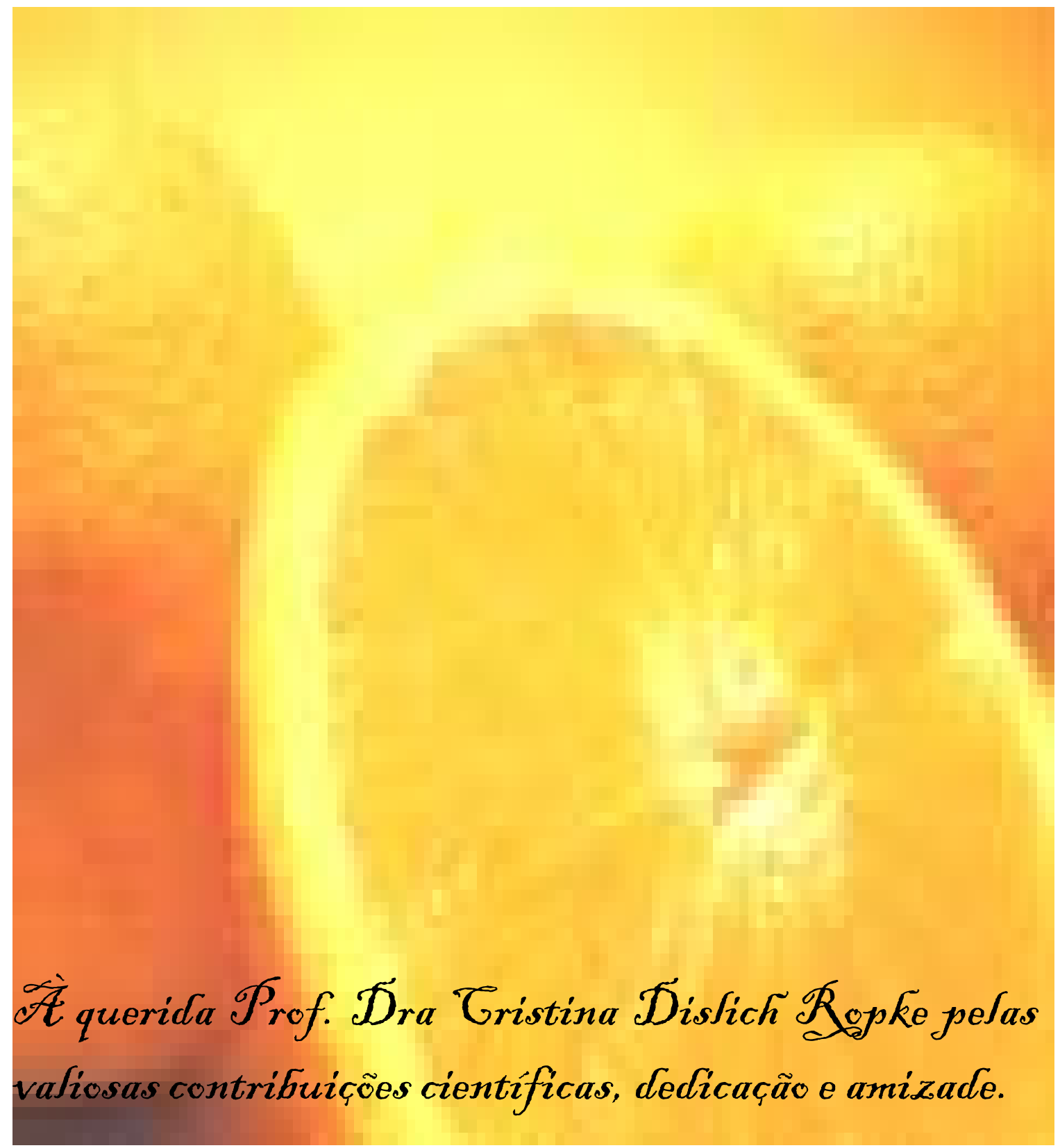



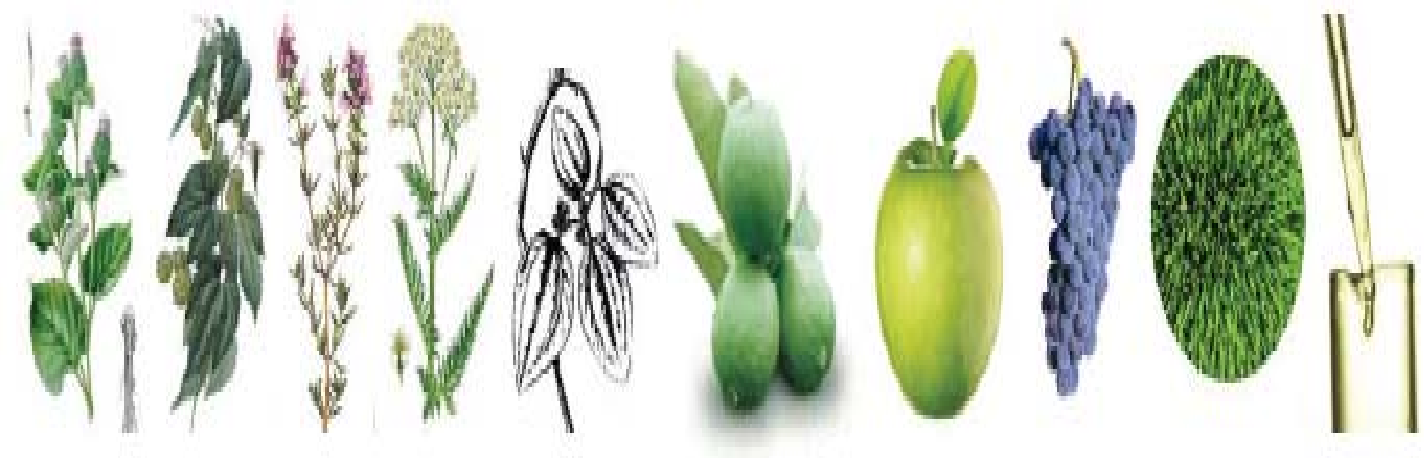

Tos professores colaboradores Livaldo do Rosário Matos e Lucildes Mercuri Pita pela doação. dedicação e por sempre me estimularem a dar o mefhor e jela confiança depositada, valorizando cada momento, me apoiando em todas as deciscoes e resolvendo as inúmeras dúvidas. Obrigada por me acolherem em seus Saboratórios e por todo apoio. 


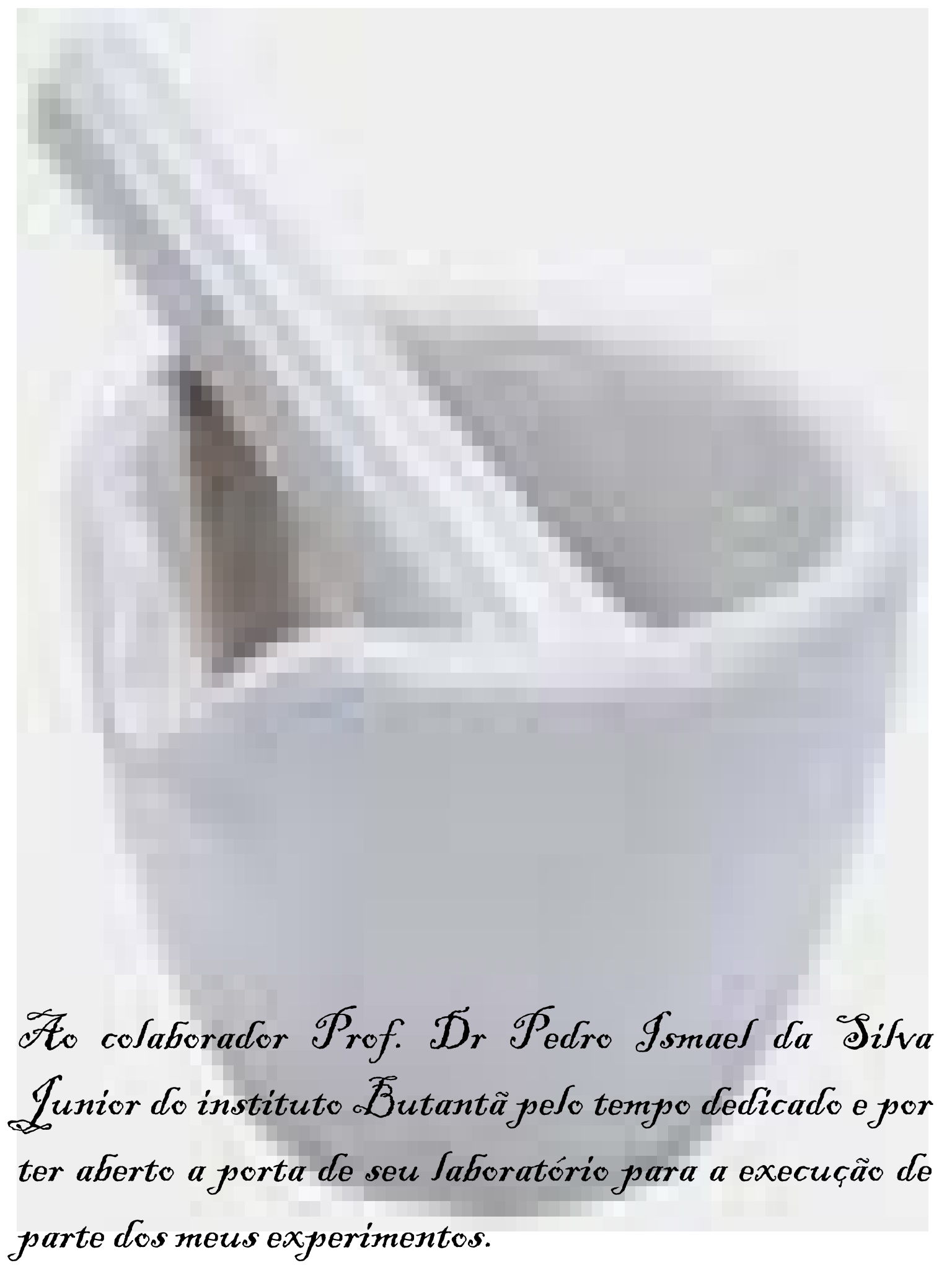




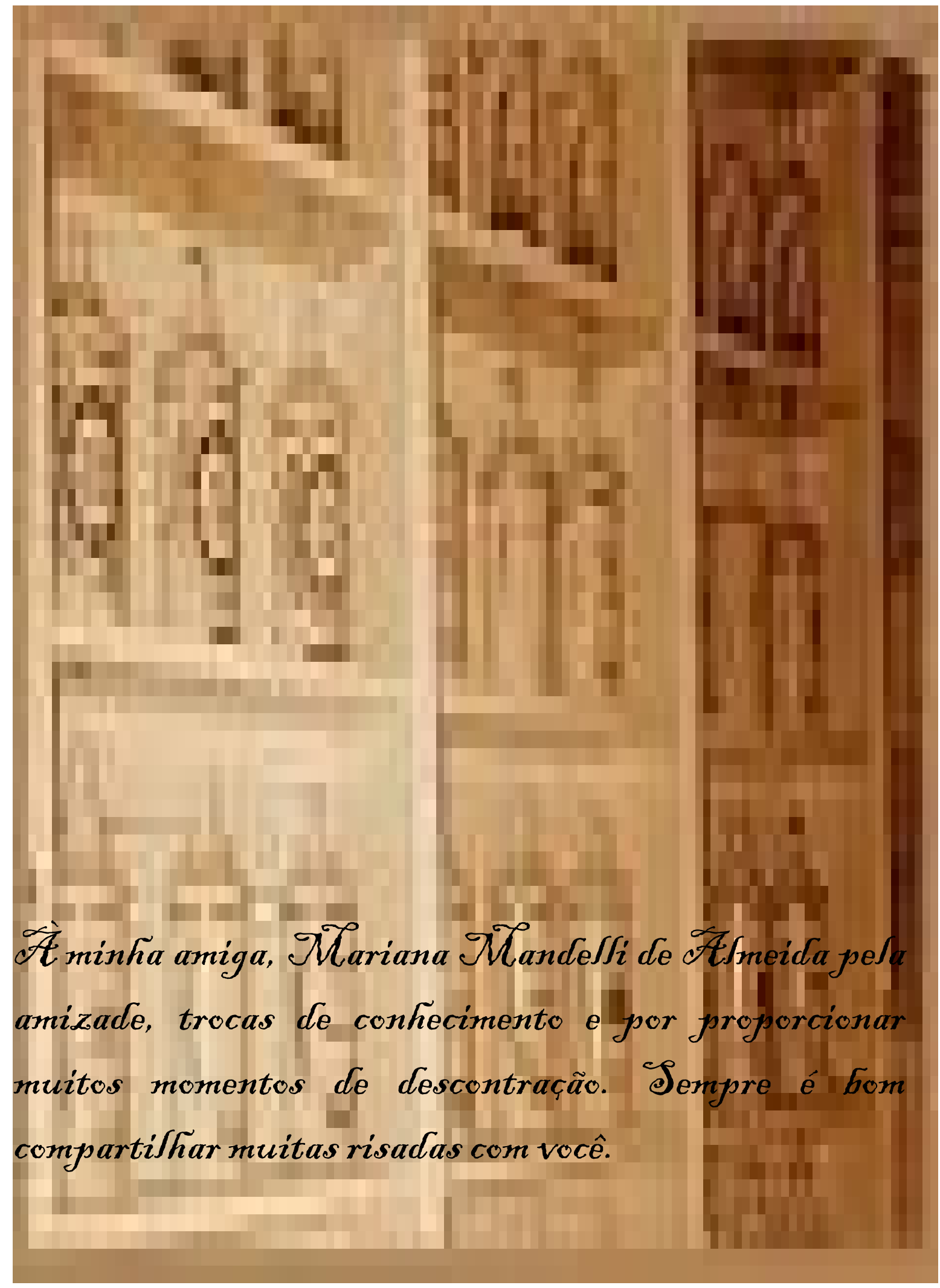




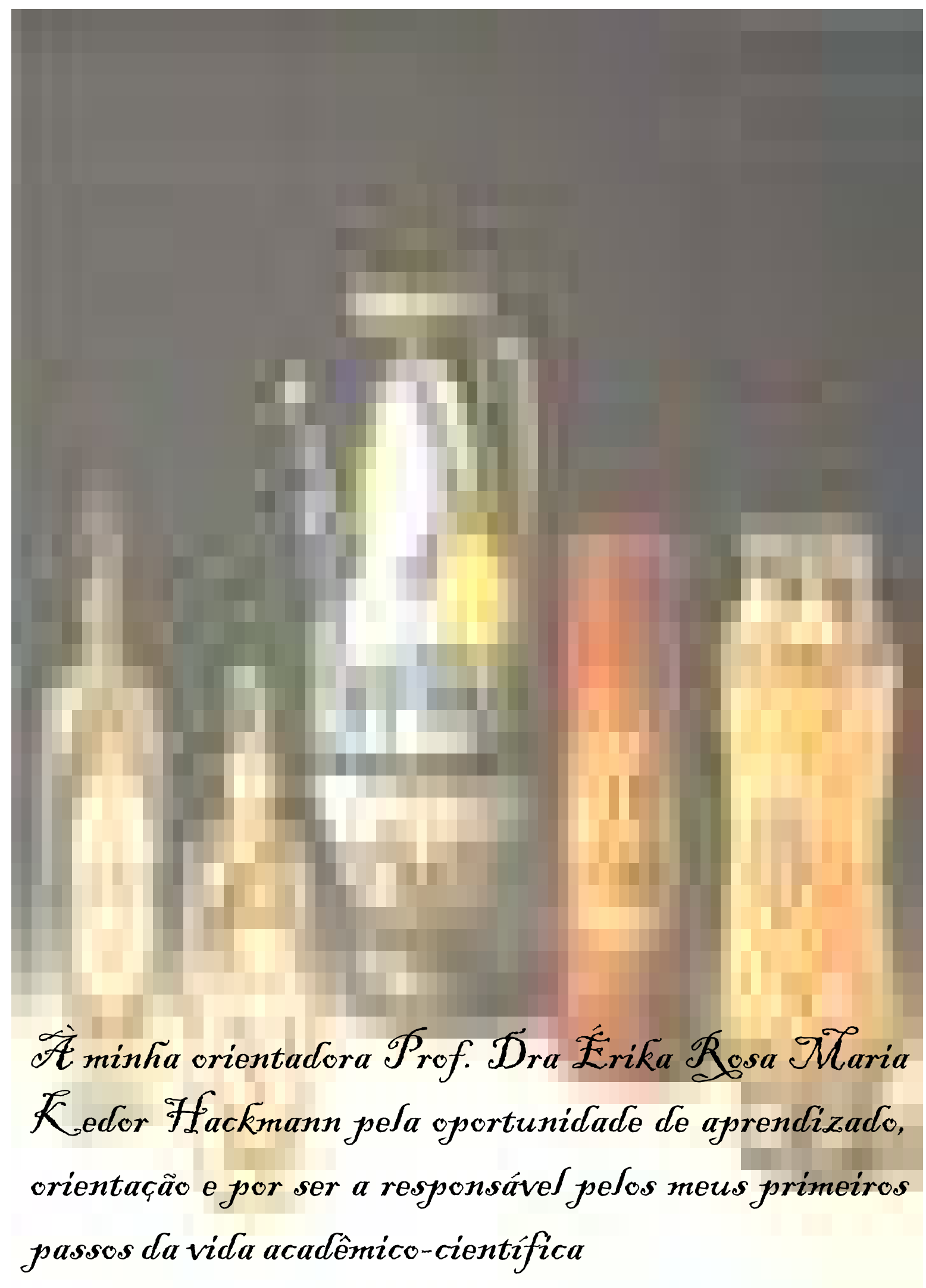




\section{Tyradecimentos}

À minha querida amiga Ingrid, da FCF-USP do laboratório de controle de qualidade físico-quimico de medicamentos e cosméticos pela amizade, apoio, idealismo e por me incentivar sempre. Obrigada pelos seus conselhos e amizade.

À Polytechno Indústrias Químicas Ltda por todo incentivo, apoio na forma de envio de amostras, patrocínio em congressos e por tornar viável a realização desse trabalho.

Ao pesquisador Diogo Pineda Rivelli pela realização e discussão dos resultados dos testes ORAC e DPPH, servindo como exemplo para outros pesquisadores de Pós Graduação.

Á Prof. Dra Silvia Berlanga de Morais Barros por ter aberto a porta do seu laboratório para a execução dos testes de ORAC e DPPH.

Aos pesquisadores do Instituto Butantã: Fernanda Portaro e Pedro Ismael da Silvia Junior por tornarem possível a execução do desenvolvimento da metodologia analítica por HPLC, abrindo a porta do seu laboratório para realização das análises e auxiliando nas discussões dos resultados obtidos.

Ao LATIG (Laboratório de Análise Térmica Ivo Giolito) por permitir o emprego das técnicas de análise térmica nesse projeto. 
À central analítica e ao departamento de Psicobiologia da UNIFESP através da Prof. Dra Lucildes Mercuri Pita e da Farmacêutica Responsável Paula Ferreira pelo empréstimo do HPLC.

À pesquisadora Fábia Rossetti da FCFRP-USP pela valiosa contribuição científica nas análises de microscopia de luz polarizada e análise de tamanho de partícula com base na execução e discussão das análises. Você é um exemplo de disciplina, agradeço pela simpatia com a qual me recebeu.

Á Prof.Dra Maria Vitória Lopes Badra Bentley da FCFRP-USP por ter aberto as portas do seu laboratório para execução das análises de tamanho de partícula e microscopia de luz polarizada .

Á FAPESP pelos projetos multiusuários números 00/09663-2 e 04/09465-7 por viabilizar a realização das análises de tamanho de partícula e microscopia e luz polarizada.

Ao farmacêutico do departamento de ciências farmacêuticas José Orestes Del Ciampo pelo manuseio dos equipamentos Beckmann Coulter $^{\circledR}$ LS 13320 Laser Diffracttion e Zetasizer Nano system ZS, Malvern ${ }^{\circledR}$ e pela atenção dada durante as análises.

À queridíssima Íria Raimunda da Silva, técnica do laboratório de controle de qualidade físico-químico de medicamentos e cosméticos, obrigada por tudo, pelos conselhos,risadas, apoio e pela amizade. 
À tia Vilma Aolfi por ter em acolhido em São Paulo, pelo apoio e incentivo. Que Jesus te abençoe grandemente.

À diretora técnica da Vital especialidades Maria Alice Marques pelo incentivo, apoio e colaboração científica, seu empenho em me ajudar foi essencial para a realização desse trabalho. Você é muito especial.

À diretora comercial da Vital especialidades Valéria Franco pelo apoio e incentivo ao trabalho

À amiga Kimie Iria pela amizade, apoio inestimável e incentivo. Você foi uma das grandes responsáveis pela concretização desse trabalho.

À Exsymol e ao Sr Georges Langrand pelo apoio, incentivo e envio de materiais técnico-científicos que propiciaram 0 enriquecimento desse trabalho.

À Prof.Dra Veni Maria Andress Felli da FCF-USP pelo auxílio na interpretação na técnica de espectrofotometria no infravermelho com transformada de Fourier.

À Regina, técnica do laboratório de controle de qualidade físico-químico de medicamentos e cosméticos, obrigada pela colaboração.

À CAPES, pelo apoio financeiro. 
Aos funcionários da biblioteca do conjunto das químicas da USP pela atenção sempre prestada.

À ABC (Associação Brasileira de Cosmetologia) por disseminar o conhecimento dentro da área cosmética propiciando através de cursos e congressos meu crescimento profissional na área de cosmetologia.

Ao meu querido irmão Renan Quenca pelos momentos de descontração, pelo apoio e pelo amor.

As minhas avós Alina Teixeira Quenca (in memorian) e Julia Soares dos Santos por acreditarem em mim, pelo incentivo e apoio.

À secretária de Pós Graduação da FCF-USP Elizabete Paiva pelo incentivo, apoio, paciência, convívio e atenção.

À coordenadora de Pós-Graduação da FCF-USP Prof.Dra Elizabeth Igne Ferreira pela oportunidade de ter me acolhido como aluna, permitindo a aquisição de conhecimentos muito importantes para minha vida profissional e pessoal.

Ao secretário de Pós-Graduação da FCF-USP Jorge de Lima obrigada pela colaboração e atenção.

Aos colegas do laboratório de controle de qualidade físicoquímico de medicamentos e cosméticos. 
À todos que direta, ou indiretamente, contribuíram ou torceram para a realização desse trabalho.

Muito obrigada. 


\section{SUMÁRIO}

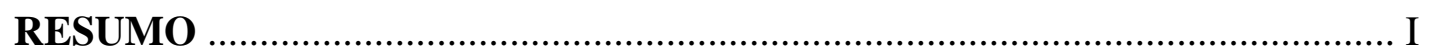

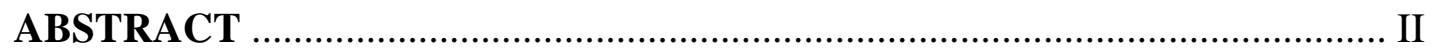

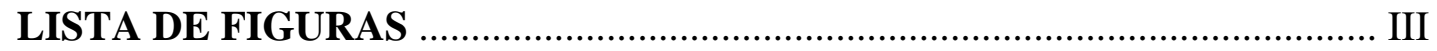

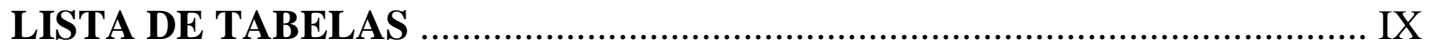

LISTA DE ABREVIATURAS ….................................................................

1. INTRODUÇÃ

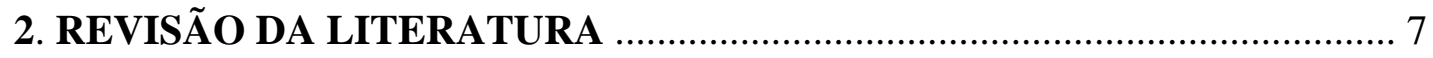

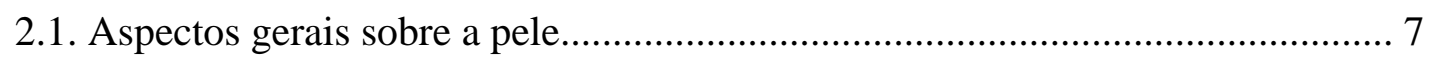

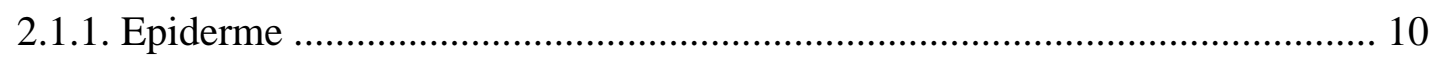

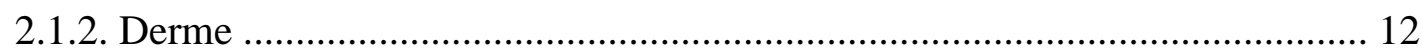

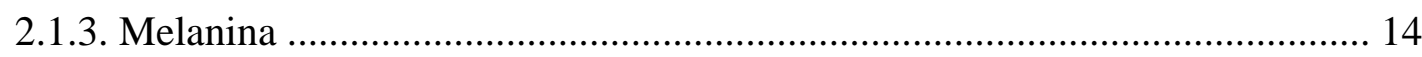

2.1.3.1. Classificação ....................................................................................... 15

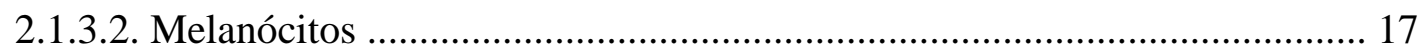

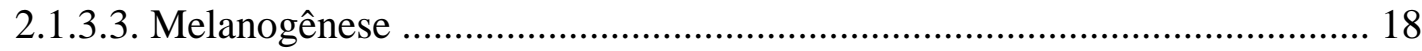

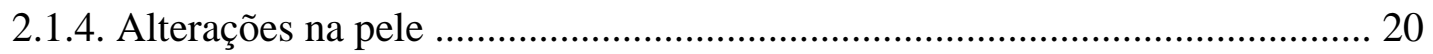

2.1.4.1. Fatores que afetam a pigmentação............................................................. 20

2.1.4.2. Envelhecimento cutâneo ....................................................................... 21

2.1.4.2.1. Radiação solar e fotoenvelhecimento .................................................. 23

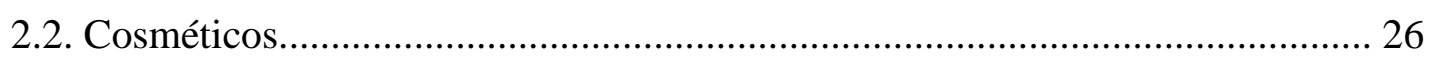


2.3.1. Características de um bom antioxidante 33

2.4. Ácido ascórbico 34

2.4.1. Derivados do ácido ascórbico 42

2.4.2. Ascorbato de monometilsilanotriol 45

2.4.3. Métodos de análise e quantificação do AA e derivados 47

2.5. Técnicas empregadas na caracterização do AMS 50

2.5.1. Espectrofotometria no ultravioleta (UV) 50

2.5.2. Espectrofotometria de absorção na região do infravermelho com transformada de Fourier (FTIR) 52

2.5.3. Cromatografia em camada delgada ...................................................... 52

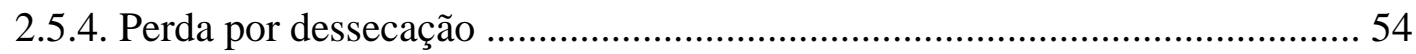

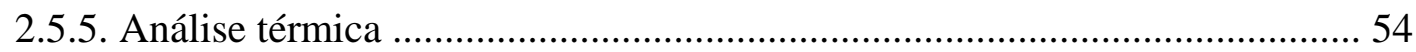

2.5.5.1. Análise térmica aplicada à cosmetologia .............................................. 57

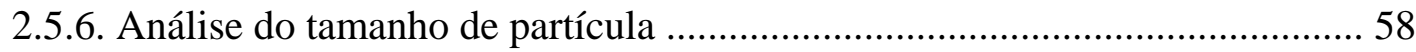

2.5.6.1. Análise da distribuição de tamanho de partícula por difração a laser......... 60 
2.6.1. Determinação da atividade antioxidante pela reação com DPPH (2,2'́-difenil1-picrilhidrazil) 64

2.6.2. Determinação do potencial antioxidante por fluorescência - ORAC (Oxigen Radical Absorbance Capacity Assay). 65

2.7. Estabilidade de formulações cosméticas ..... 65

2.8. Microscopia 67

2.9. Cromatografia Líquida de Alta Eficiência (CLAE) 68

2.10. Validação de métodos analíticos 69

3. OBJETIVOS 72

3.1. Objetivo geral 72

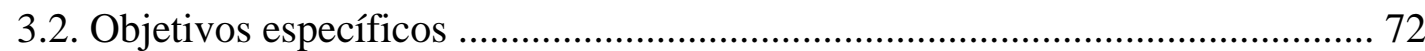

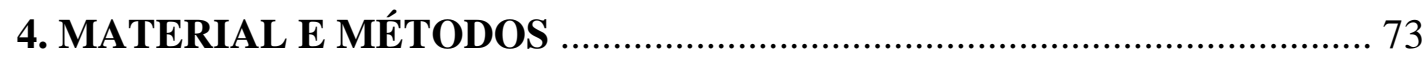

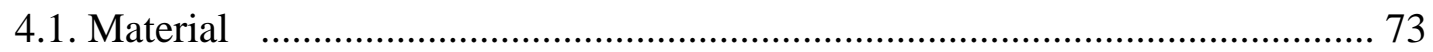

4.1.1. Matérias-primas empregadas no desenvolvimento das formulações ............ 73

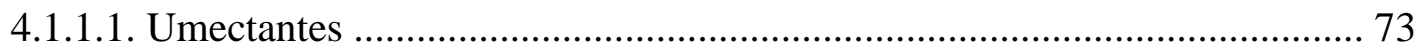

4.1.1.2. Surfactantes poliméricos e espessantes orgânicos solúveis em água (não iônicos) 74

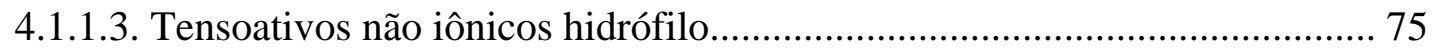

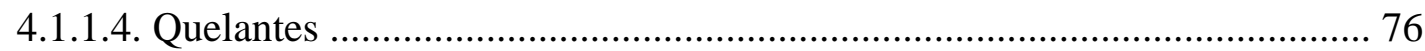

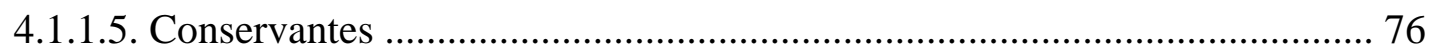

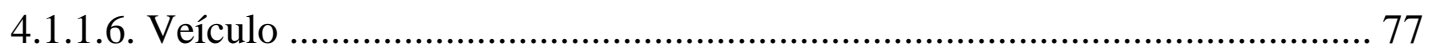




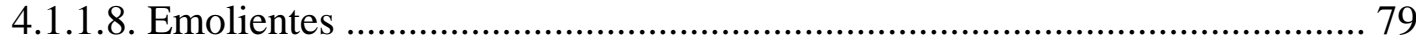

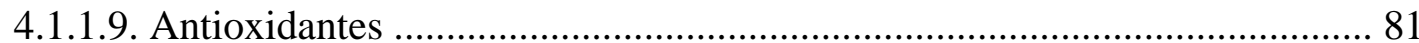

4.1.1.10. Espessantes orgânicos de fase oleosa e co-emulsionantes ..................... 81

4.1.1.11. Tensoativos não iônicos para componentes oleosos ................................. 83

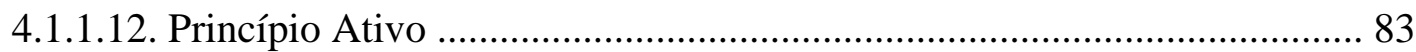

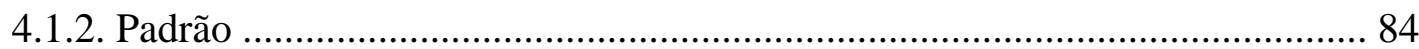

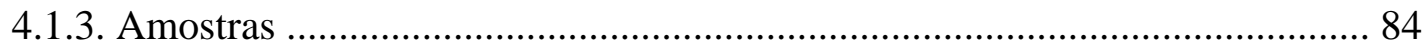

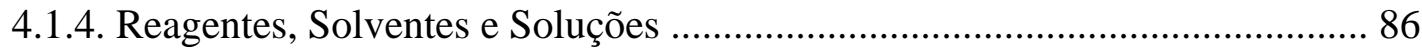

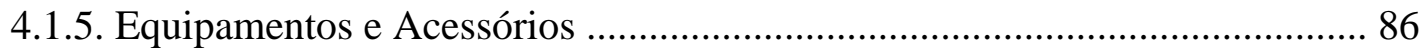

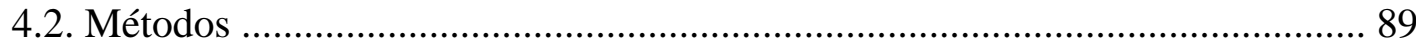

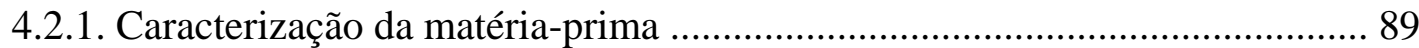

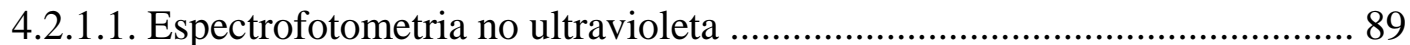

4.2.1.2. Espectrofotometria na região do infravermelho com transformada de Fourier (FTIR) 89

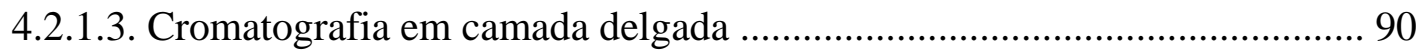

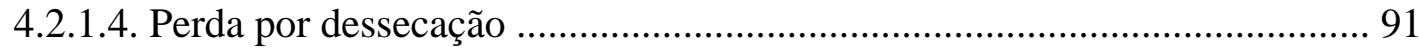

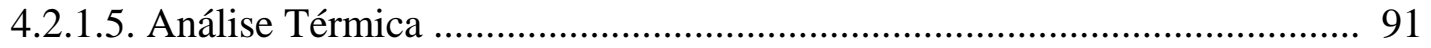

4.2.1.5.1. Caracterização via termogravimetria (TG)/termogravimetria derivada

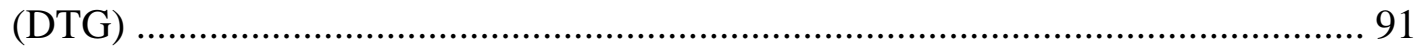

4.2.1.5.2.Caracterização via Calorimetria Exploratória Diferencial (DSC) ............ 92 
4.2.1.5.2.3. Caracterização do AMS por DSC empregando a água destilada como padrão 92

4.2.1.6. Análise do Tamanho de Partícula 93

4.2.1.6.1. Análise da distribuição de tamanho de partícula por difração a laser ..... 93 4.2.1.6.2. Análise da distribuição de tamanho de partícula por espalhamento dinâmico de luz 93

4.2.2.1. Determinação da atividade antioxidante pela reação com

DPPH. 94

4.2.2.2. Determinação do potencial antioxidante por fluorescência - ORAC 95

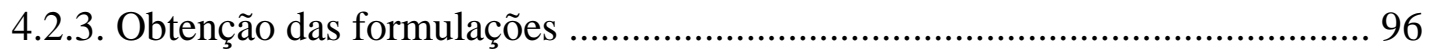

4.2.3.2. Teste de estabilidade preliminar .............................................................. 97

4.2.3.3. Determinação do tipo de emulsão ........................................................... 98

4.2.3.4. Condições de armazenamento para o teste de estabilidade acelerada ........ 98

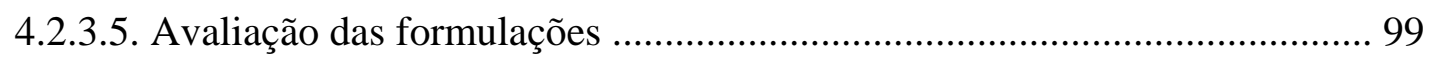

4.2.4.1. Análise de tamanho de partícula por difração a l aser (ATP-DL) ........... 99

4.2.4.2. Análise microscópica das formulações ................................................... 100

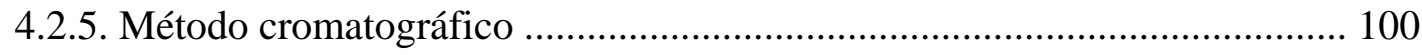

4.2.5.1. Parâmetros estabelecidos ...................................................................... 101 
4.2.5.2.1. Preparo da fase móvel

4.2.5.2.4. Quantificação do teor de AMS nas formulações cosméticas obtidas .....103

4.2.5.2.5. Exatidão (Recuperação) 103

4.2.5.2.6. Determinação dos limites de detecção e quantificação 105

4.2.5.2.7. Estabilidade das soluções padrão 106

5. RESULTADOS 107

5.1. Caracterização da matéria-prima 108

5.1.1. Espectro no ultravioleta 108

5.1.2. Espectro no infravermelho 109

5.1.3. Cromatografia em camada delgada 110

5.1.4. Perda por dessecação 110

5.1.5. Análise Térmica

5.1.5.1. Termogravimetria (TG)/termogravimetria derivada (DTG) 110

5.1.5.2. Caracterização via calorimetria exploratória diferencial (DSC) 111

5.1.6. Análise da distribuição de tamanho de partícula por difração a laser 116

5.1.7. Análise da distribuição de tamanho de partícula por espalhamento dinâmico de luz 117

5.2. Avaliação do potencial antioxidante in vitro do AMS. 
5.2.1. Determinação da atividade antioxidante pela reação com DPPH

5.2.2. Determinação do potencial antioxidante por fluorescência - ORAC 120

5.3. Avaliação das formulações cosméticas obtidas

5.3.1. Teste de estabilidade preliminar 122

5.3.2. Determinação do tipo de emulsão 123

5.3.3. Teste de estabilidade acelerada 124

5.3.3.1. Visualização das cores das formulações submetidas ao teste de estabilidade acelerada 131

5.3.4. Análise do tamanho de partícula por difração a laser 135

5.3.5. Análise microscópica das formulações 139

5.4. Método Cromatográfico 142

5.4.1. Construção da curva de calibração do método cromatográfico e tratamento estatístico 142

5.4.2. Pesquisa de interferentes 143

5.4.3. Quantificação do teor de AMS nas formulações cosméticas obtidas 143

5.4.4. Exatidão 144

5.4.5. Limite de detecção e quantificação 145

5.4.6. Estabilidade da solução padrão 145

6. DISCUSSÃO 150

7. CONCLUSÕES 160

8. BIBLIOGRAFIA 162 


\title{
CARACTERIZAÇÃO E ANÁLISES DO ASCORBATO DE MONOMETILSILANOTRIOL EM FORMULAÇÕES COSMÉTICAS
}

\begin{abstract}
RESUMO
O ascorbato de monometilsilanotriol (AMS) apresenta as propriedades cosméticas do ácido ascórbico. Além de ser um antioxidante e despigmentante, o AMS apresenta silício em sua estrutura, assim sua presença em formulações tópicas tem como objetivo repor o silício endógeno, proporcionando a regeneração do tecido. O presente trabalho tem por objetivo, caracterizar e analisar o AMS formulações cosméticas. Para caracterização do princípio ativo, foram empregadas as seguintes técnicas: espectrofotometria no ultravioleta, espectrofotometria na região do infravermelho com transformada de Fourier (FTIR), cromatografia em camada delgada, perda por dessecação, calorimetria exploratória diferencial (DSC), termogravimetria (TG), termogravimetria derivada (DTG) e análise do tamanho de partícula. Avaliou-se o potencial antioxidante in vitro do AMS pelos métodos de DPPH (2,2'-difenil-1picrilhidrazil) e ORAC(Oxigen Radical Absorbance Capacity Assay) . Para avaliar o comportamento do princípio ativo em formulações cosméticas foi realizado um estudo de estabilidade acelerada, no qual as mesmas foram armazenadas nas seguintes condições: $40^{\circ} \mathrm{C} \pm 2$, câmera de fotoestabilidade $25^{\circ} \mathrm{C}$, armário fechado à temperatura de $25^{\circ} \mathrm{C} \pm 2$ e geladeira a $5^{\circ} \mathrm{C} \pm 2$. Foram avaliados os caracteres organolépticos, o $\mathrm{pH}$ e viscosidade aparente, também foram efetuadas análises por DSC, tamanho de partícula e microscopia de luz polarizada. Para determinação do AMS foi desenvolvido e validado um método por cromatografia líquida da alta eficiência (CLAE) em fase reversa por pareamento iônico. De acordo com os resultados obtidos por TG/DTG/DSC pode-se associar o comportamento térmico do ativo isolado com aquele da espécie incorporada em formulações. Segundo o método de tamanho de partícula, pode-se avaliar que o AMS, apresentou tamanho de aproximadamente $1 \mu \mathrm{m}(919 \mathrm{~nm})$ e índice de polidispersidade de 0,111. Durante os experimentos para determinação da atividade antioxidante por DPPH, o AMS demonstrou ter propriedade antioxidante tão efetiva quanto o ácido ascórbico. O valor de ORAC obtido para o AMS $(0,74)$ é próximo ao valor de ORAC para o ácido ascórbico $(0,95)$. As formulações estudadas mantiveram suas características organolépticas, estabilidade física e viscosidade aparente, assim como, não sofreram alterações relevantes em termos de $\mathrm{pH}$ durante o período de 90 dias. A metodologia desenvolvida para determinação do AMS apresentou boa linearidade, precisão, limites de detecção e quantificação, podendo ser usada na análise de formulações cosméticas. Esse princípio ativo, mostrou ser uma excelente alternativa, como derivado do ácido ascórbico, por apresentar atividade antioxidante in vitro tão eficiente quanto à desse, assim como, uma estabilidade superior em formulações cosméticas.
\end{abstract}

Palavras - chave: ascorbato de monometilsilanotriol, ácido ascórbico, formulações cosméticas, validação de métodos analíticos. 


\title{
CHARACTERIZATION AND ANALYSIS OF MONOMETHYLSILANETRIOL ASCORBATE IN COSMETIC FORMULATIONS
}

\begin{abstract}
The monomethylsilanetriol ascorbate( MSA) presents the same functional properties of vitamin C. Besides present's antioxidant and depigmentant activity, the monomethylsilanetriol ascorbate presents silanol in it chemical structure. The silanol is a privileged active ingredient for cosmetics because it essential for growth, development and regeneration of cutaneous connective tissue. The aim of this work was characterize and analyze the MSA in cosmetic formulations. To characterize and identified MSA was employed: ultraviolet/visible (UV/VIS) spectrophotometry, fourier transform infrared spectrophotometry (FTIR), thin layer chromatography (TLC), thermogravimetry/derivative thermogravimetry (TG/DTG), differential scanning calorimetry (DSC) and particle size determination. For MSA in vitro antioxidant activity evaluation the DPPH (2,2-diphenyl-1-picrylhydrazyl) and ORAC (Oxigen Radical Absorbance Capacity Assay) method were used. To evaluate the behavior of MSA in cosmetic formulations the samples of emulsions were submitted to the accelerated stability study, for 90 days, were stored at $40 \pm 2{ }^{\circ} \mathrm{C}$ and light $25 \pm 2{ }^{\circ} \mathrm{C}$. All samples were also stored at room temperature protected from light. Appearance, $\mathrm{pH}$ and apparent viscosity were evaluated. The DSC, particle size analyze and microscopy also were employed for analyze the cosmetic formulations. To determine MSA in formulations it was employed and validated a reversed phase HPLC method with ion pairing. According to the results obtained by TG/DTG/DSC the thermal behavior of isolated MSA can be associated with thermal behavior of MSA in formulations. Particle size distributions results showed that the average size was approximately $1 \mu \mathrm{m}$ for MSA (919 $\mathrm{nm}$ ) and polydispersity index of 0,111. During DPPH experiments, MSA presented antioxidant properties as good as vitamin $\mathrm{C}$. The value of ORAC obtained for MSA was $(0,74)$. The value of ORAC for ascorbic acid is 0,95 . All samples remained stable throughout stability studies period. The developed methodology for determination of MSA presented good linearity, precision, limit of quantification and limit of detection and can be employed for analyze cosmetic formulations containing MSA. In conclusion, MSA might have interesting applications in cosmetic products and can be a good alternative for ascorbic acid derivative because it for demonstrated strong in vitro antioxidant properties as efficient as and more stable than vitamin $\mathrm{C}$.
\end{abstract}

Keywords: monomethylsilanetriol ascorbate, ascorbic acid, cosmetic formulations, validation of analytical methods. 


\section{LISTA DE FIGURAS}

Figura 1. Estrutura esquemática da pele 8

Figura 2. Corte histológico da epiderme 11

Figura 3. Esquema ilustrativo da derme .13

Figura 4. Superfície da derme papilar em SEM .13

Figura 5. Ilustração da derme reticular 14

Figura 6. Esquema do melanócito na epiderme 15

Figura 7. Micrografia do melanócito em contato com o queraticnócito e melanossomas transferidos 17

Figura 8. Fotomicrografias dos melanócitos de pele clara e escura respectivamente....18

Figura 9. Etapas químicas da melanogênese 20

Figura 10. Diferenciação histológica de pele jovem e envelhecida intrinsecamente. Espécimes de pele dos grupos jovem (A) e idoso (B) corados pelo tricrômio de Van Gieson-elastina, em que as fibras elásticas são observadas em preto 22

Figura 11. Efeitos da radiação UV na pele 25

Figura 12. Penetração da radiação solar na pele 26

Figura 13. Óleo mineral em emulsão aquosa 28 
Figura 14. Esquema demonstrativo de regulação fisiológica modulada pelo estado redox intracelular

Figura 15. Estrutura química do ácido ascórbico na formas plana e tridimensional .... 35

Figura 16. Esquema da síntese do AA a partir da D-Glucose 35

Figura 17. Estrutura química do ácido $L$-deidroascórbico ........................................ 36

Figura 18. Oxidação do ácido ascórbico a $L$-deidroascórbico .................................. 36

Figura 19. Ácido $L$-deidroascórbico na forma da espécie bicíclica hidratada ..............37

Figura 20. Reação de decomposição do ácido deidroascórbico ................................... 37

Figura 21. Cristais do ácido ascórbico vistos com luz polarizada ............................... 38

Figura 22. Estrutura química do tocoferol e tocotrienol ............................................ 40

Figura 23. Etapas da lipoperoxidação e ação antioxidante do $\alpha$-tocoferol ................... 41

Figura 24. Estrutura química do fosfato ascorbil magnésio ..................................... 42

Figura 25. Estrutura química do tetraisopalmitato de ascorbila ............................... 43

Figura 26. Estrutura química do palmitato de ascorbila ............................................ 43

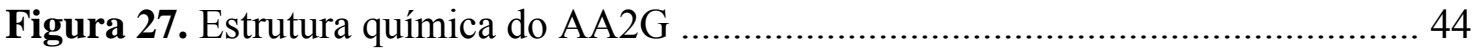

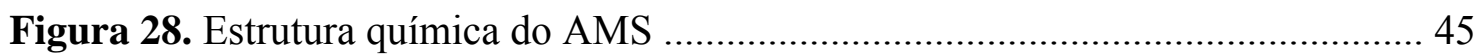

Figura 29. Exemplificação da análise do Rf por CCD ............................................... 54

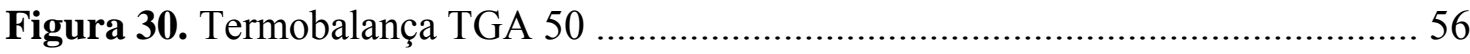

Figura 31. Célula DSC 50 e vista do interior da célula ............................................. 57

Figura 32. Diferentes diâmetros de esferas equivalentes geradas a partir de uma

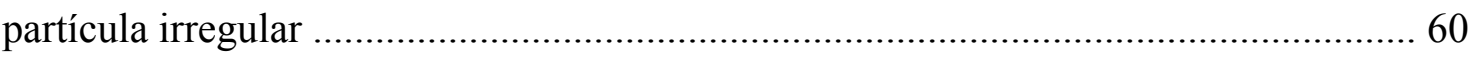

Figura 33. Esquema de um equipamento de análise de tamanho de partícula por

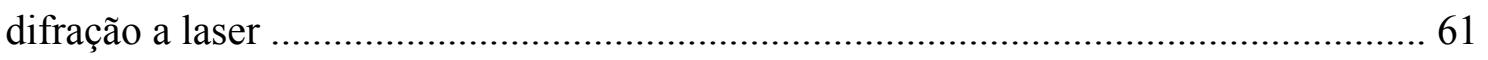

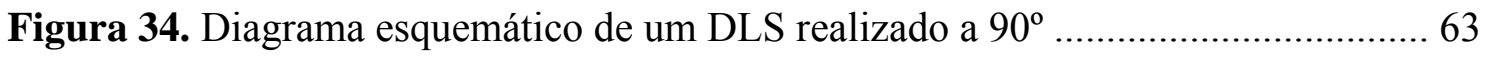


Figura 35. Diagrama esquemático mostrando a posição de medição para: (a) amostras pequenas e que espalham pouco a luz; (b) amostras concentradas e opacas, que espalham bastante a luz 64

Figura 36. Espectro de absorção no ultravioleta da solução de AMS $(16 \mu \mathrm{g} / \mathrm{mL})$ em $\mathrm{H}_{2} \mathrm{SO}_{4} 0,1 \mathrm{~N}$, pico máximo em $247 \mathrm{~nm}$ 107

Figura 37. Espectro de absorção na região do infravermelho do AMS em filme sobre placa de $\mathrm{KBr}$ 108

Figura 38. Placa cromatográfica de identificação do AMS. Fase móvel: etanol 10\% e ácido acético $90 \%$, fase estacionária sílica gel $60 \mathrm{Merck}^{\circledR}$, utilizando ninidrina como revelador, $\operatorname{Rf} 0,58$ 109

Figura 39. Curvas TG/DTG do AMS obtidas nas seguintes condições: razão de aquecimento $5{ }^{\circ} \mathrm{C} / \mathrm{min}, 25$ à $150{ }^{\circ} \mathrm{C}$, massa da amostra de $5,0 \mathrm{mg}$ sob atmosfera dinâmica de $\mathrm{N}_{2}(50 \mathrm{~mL} / \mathrm{min})$ 110

Figura 40. Curva DSC do AMS obtida nas seguintes condições: razão de aquecimento $5^{\circ} \mathrm{C} / \mathrm{min}, 25$ à $150^{\circ} \mathrm{C}$, massa da amostra de $2,0 \mathrm{mg}$ sob atmosfera dinâmica de $\mathrm{N}_{2}(100$ $\mathrm{mL} / \mathrm{min})$ 111

Figura 41. Curvas DSC das formulações F1 e F1A obtidas nas seguintes condições: razão de aquecimento $5{ }^{\circ} \mathrm{C} / \mathrm{min}, 25$ à $150{ }^{\circ} \mathrm{C}$, massa das amostras de $2,0 \mathrm{mg}$ sob atmosfera dinâmica de $\mathrm{N}_{2}(100 \mathrm{~mL} / \mathrm{min})$ 112

Figura 42. Curvas DSC das formulações F2 e F2A obtidas nas seguintes condições: razão de aquecimento $5{ }^{\circ} \mathrm{C} / \mathrm{min}, 25$ à $100{ }^{\circ} \mathrm{C}$, massa das amostras de $2,0 \mathrm{mg} \mathrm{sob}$ atmosfera dinâmica de $\mathrm{N}_{2}(100 \mathrm{~mL} / \mathrm{min})$ 113 
Figura 43. Curvas DSC das formulações F3 e F3A obtidas nas seguintes condições: razão de aquecimento $5^{\circ} \mathrm{C} / \mathrm{min}, 25$ à $100{ }^{\circ} \mathrm{C}$, massa das amostras de $2,0 \mathrm{mg}$ sob atmosfera dinâmica de $\mathrm{N}_{2}(100 \mathrm{~mL} / \mathrm{min})$ 114

Figura 44. Curvas DSC da água destilada e do AMS obtidas nas seguintes condições: razão de aquecimento $5{ }^{\circ} \mathrm{C} / \mathrm{min}$, ciclos de resfriamento-aquecimento entre 25 e $-60{ }^{\circ} \mathrm{C}$, massa das amostras de 10,0 mg sob atmosfera dinâmica de $\mathrm{N}_{2}(100 \mathrm{~mL} / \mathrm{min})$ 115

Figura 45. Gráfico da distribuição do tamanho de partícula do AMS (solução aquosa à $1 \%)$ por difração a laser 116

Figura 46. Gráfico da distribuição do tamanho de partícula do AMS (solução aquosa à 1\%) por espalhamento dinâmico de luz

Figura 47. Avaliação estatística da atividade antioxidante do ácido ascórbico pela reação com DPPH 118

Figura 48. Avaliação estatística da atividade antioxidante do ácido ascórbico pela reação com DPPH

Figura 49. Avaliação estatística da determinação do potencial antioxidante do AMS obtido pelo ORAC 120

Figura 50. Efeito da concentração de Trolox sob a curva de decaimento de fluorescência, apresentando potencial antioxidante de 0,597 $\pm 0,043$ eq Trolox sendo que, a molaridade está baseada na concentração de ácido ascórbico presente na solução de ascorbato de monometilsilanotriol

Figura 51. Fotografias das formulações, no (T1). 131

Figura 52. Fotografias das formulações no (T30) 132

Figura 53. Fotografias das formulações no (T60) 133

Figura 54. Fotografias das formulações no (T30) 134 
Figura 55. Gráfico da distribuição do tamanho de partícula das formulações F1 e F1A

Figura 56. Gráfico da distribuição do tamanho de partícula das formulações F2 e

F2A

Figura 57. Gráfico da distribuição do tamanho de partícula das formulações F3 e

F3A

Figura 58. Fotomicrografias sob luz polarizada das formulações $A(F 1)$ e B(F1A) ... 139

Figura 59. Fotomicrografias sob luz polarizada das formulações A(F2) e B(F2A) ... 140

Figura 60. Fotomicrografias sob luz polarizada das formulações A(F3) e B(F3A) ... 141

Figura 61. Curva de calibração obtida pelo método cromatográfico 142

Figura 62. Gráfico da avaliação da estabilidade da solução padrão de AMS após sofrer descongelamento 145

Figura 63. Perfil cromatográfico do ascorbato de monometilsilanotriol $(2,5 \mu \mathrm{g} / \mathrm{mL})$.

Condições cromatográficas: coluna Synergi-Hydro ${ }^{\circledR}$ RP Phenomenex ${ }^{\circledR} 150$ X 4,6 mm, partícula de $4 \mu, 80 \AA$ de poro, C18, fase móvel: metanol:água $(30: 70 \mathrm{v} / \mathrm{v})+\mathrm{TBA} 30 \mathrm{mM}$ $(\mathrm{pH}=5,94)$, vazão $1 \mathrm{~mL} / \mathrm{min}$, detecção a $254 \mathrm{~nm}$; temperatura ambiente 146

Figura 64. Perfil cromatográfico da formulação (F1A) $(45 \mu \mathrm{g} / \mathrm{mL})$. Condições cromatográficas: coluna Synergi-Hydro ${ }^{\circledR}$ RP Phenomenex ${ }^{\circledR} 150$ X 4,6 mm, partícula de $4 \mu, 80 \AA \AA$ de poro, C18, fase móvel: metanol:água $(30: 70 \mathrm{v} / \mathrm{v})+\mathrm{TBA} 30 \mathrm{mM}(\mathrm{pH}=5,94)$, vazão $1 \mathrm{~mL} / \mathrm{min}$, detecção a $254 \mathrm{~nm}$; temperatura ambiente 147

Figura 65. Perfil cromatográfico da formulação (F2A) $(4,5 \mu \mathrm{g} / \mathrm{mL})$. Condições cromatográficas: coluna Synergi-Hydro ${ }^{\circledR} \mathrm{RP}$ Phenomenex ${ }^{\circledR} 150 \mathrm{X}$ 4,6 mm, partícula de $4 \mu, 80 \AA$ de poro, $\mathrm{C} 18$, fase móvel: metanol:água $(30: 70 \mathrm{v} / \mathrm{v})+\mathrm{TBA} 30 \mathrm{mM}(\mathrm{pH}=5,94)$, vazão $1 \mathrm{~mL} / \mathrm{min}$, detecção a $254 \mathrm{~nm}$; temperatura ambiente 148 
Figura 66. Perfil cromatográfico da formulação (F3A) $(4,5 \mu \mathrm{g} / \mathrm{mL})$. Condições cromatográficas: coluna Synergi-Hydro ${ }^{\circledR} \mathrm{RP}$ Phenomenex ${ }^{\circledR} 150 \mathrm{X}$ 4,6 mm, partícula de $4 \mu, 80 \AA \AA$ de poro, $\mathrm{C} 18$, fase móvel: metanol:água $(30: 70 \mathrm{v} / \mathrm{v})+\mathrm{TBA} 30 \mathrm{mM}(\mathrm{pH}=5,94)$, vazão $1 \mathrm{~mL} / \mathrm{min}$, detecção a $254 \mathrm{~nm}$; temperatura ambiente 149 


\section{LISTA DE TABELAS}

Tabela 1. Variação do pH da pele em partes do corpo humano 10

Tabela 2. Tabela de variações na pigmentação entre as três raças maiores

Tabela 3. Comprimento de onda aproximado das cores 51

Tabela 4. Descrição farmacotécnica das emulsões cosméticas obtidas e avaliadas durante o estudo 85

Tabela 5. Esquema das alíquotas das soluções padrão e amostra obtidas para o ensaio da exatidão 104

Tabela 6. Bandas de absorção obtidas na determinação do espectro no infravermelho do AMS em filme sob placa de $\mathrm{KBr}$ 108

Tabela 7 . Distribuição do tamanho de partícula $(\mu \mathrm{m})$ do AMS por difração a laser.. 116

Tabela 8. Resultados obtidos nos testes preliminares de estabilidade 122

Tabela 9. Resultados obtidos nos testes de determinação do tipo de emulsão 123

Tabela 10. Características das formulações cosméticas no T0 (logo após a obtenção das formulações) 124

Tabela 11. Características das formulações cosméticas no T1 125

Tabela 12. Características das formulações cosméticas no T7 126

Tabela 13. Características das formulações cosméticas no T15

Tabela 14. Características das formulações cosméticas no T30 128

Tabela 15. Características das formulações cosméticas no T60

Tabela 16. Características das formulações cosméticas no T90 130 
Tabela 17. Distribuição do tamanho de partícula $(\mu \mathrm{m})$ das formulações cosméticas por difração a laser 135

Tabela 18. Análise estatística dos resultados obtidos na determinação da curva analítica do ascorbato de monometilsilanotriol (AMS) pelo método cromatográfico 143

Tabela 19. Resultados das análises nas amostras F1A, F2A e F3A aplicando o método cromatográfico e o tratamento estatístico dos dados obtidos 144

Tabela 20. Resultados obtidos na recuperação de solução padrão de AMS (solução aquosa à 1\%) adicionada as formulações cosméticas empregando o método cromatográfico 144 


\section{LISTA DE ABREVIATURAS E SÍMBOLOS}

ANVISA - Agência Nacional de Vigilância Sanitária

FDA - Food and Drug Administration

IBGE - Instituto Brasileiro de Geografia e Estatística

INCI - International Cosmetics Ingredients

UV - Ultravioleta

OTC - Over the Counter

MSH - Melanocyte Stimulating Hormone

DHI - 5,6-dihidroxiindol

DHICA - 5,6-dihidroxiindol-2-ácido carboxílico

AA - Ácido Ascórbico

AAG2 - Ácido Ascórbico 2-glicosado

AMS - Ascorbato de Monometilsilanotriol

ATP - Análise do Tamanho de Partícula

ATP-DL - Análise do Tamanho de Partícula por Difração a Laser

CAS - Chemical Abstracts Service

CCD - Cromatografia em Camada Delgada

CLAE - Cromatografia Líquida de Alta Eficiência

DSC - Calorimetria Exploratória Diferencial

TG - Termogravimetria

DTG- Termogravimetria Derivada

DLS - Espalhamento Dinâmico de Luz

DPPH - 2,2'-difenil-1-picrilhidrazil

FTIR - Espectrofotometria na região do infravermelho com transformada de Fourier 
LD - Limite de detecção

LQ - Limite de quantificação

NADPH - Nicotinamida adenina dinucleótido fosfato

NADH - Nicotinamida adenina dinucleotídeo

ORAC - Oxigen Radical Absorbance Capacity Assay

ROS/RNS - Espécies reativas de oxigênio e de nitrogênio 


\section{INTRODUÇÃO}

O conceito de beleza procurado pela grande maioria das mulheres é o de uma pele jovem, sem manchas ou rugas. Mas, inexoravelmente com o avanço da idade e mudanças hormonais, a pele começa a sofrer alterações que modificam gradativamente seu aspecto, aparecendo, então, as marcas do envelhecimento cutâneo. Segundo FONSECA, cerca de $80 \%$ dos sinais visíveis de envelhecimento são causados pelos raios UV. Esse tipo de envelhecimento das células se faz visível em forma de rugas, aspereza ou falta de pigmentação. Os principais causadores dessas mudanças na pele são os radicais livres, sendo que seu envolvimento nos danos causados pela radiação UV já está bem estabelecido. Com base nessas informações, o mercado de cosméticos global vem crescendo de forma ampla e tem buscado o desenvolvimento de princípios ativos que combatam simultaneamente as manchas e o envelhecimento cutâneo (FONSECA, 2003).

Os cuidados em relação à radiação ultravioleta tornaram-se vitais, uma vez que a exposição desprotegida ao sol causa diversos efeitos prejudiciais à saúde, provocando danos oculares, ao sistema imunológico e à pele. No entanto, o culto ao bronzeamento atingiu limites de exagero resultando no crescente aumento das dermatoses de origem actínica, com particular destaque para os carcinomas cutâneos. Os efeitos bioquímicos da radiação além de catalisar a síntese de vitamina $\mathrm{D}$, a pigmentação da pele, hiperplasia epidérmica, perspiração, e envelhecimento, podem ocasionar reações fotossensibilizantes, fototóxicas, fotoalérgicas, eritema, queimadura solar, fotoenvelhecimento e câncer. Um dos processos mais importantes de defesa natural que o organismo dispõe para se proteger da agressão solar é o aumento da pigmentação 
levando a formação de manchas. Esses dados intensificam a necessidade de estudos de princípios ativos despigmentantes que sejam eficazes no tratamento desses distúrbios cutâneos provocados pelo sol (SCOTTI \& VELASCO, 2003).

A aplicação tópica do ácido ascórbico e seus derivados têm despertado grande interesse pela comunidade científica, uma vez que seus efeitos na hidratação cutânea, atenuação de manchas e ação antioxidante, têm sido cada vez mais observados por profissionais da área cosmética e dermatológica e pelos próprios usuários (SPICLIN et al, 2001).

A vitamina $\mathrm{C}$ atua como um inibidor da biossíntese melânica, pois reduz a formação de dopaquinona, atuando na melanina formada transformando-a em leucomelanina. Trabalhos realizados em humanos mostraram que o tratamento tópico com vitamina $\mathrm{C}$ reduz realmente o eritema induzido pela radiação UVB. A concentração de uso da vitamina C varia de 1 a 20\% (GONÇALVES, 2001; MAIA - CAMPOS \& SILVA, 2000).

Dentre as principais ações do ácido ascórbico estão a neutralização de ânions superóxido $\left(\mathrm{O}_{2}\right)$ e oxigênios reativos. Funciona também como um antioxidante de quebra de cadeia, pois após a transferência de um único elétron, o radical livre ascorbato tem potencial pró-oxidante relativamente baixo. O ácido ascórbico destaca-se por ser reafirmante participando como co-fator na hidroxilação da hidroxiprolina, importante aminoácido do tecido conjuntivo e das fibras colágenas, contribuindo, assim de forma significativa para a formação de novas fibras colágenas, melhorando a elasticidade e firmeza cutânea considerada maior alvo do envelhecimento (MAIA- CAMPOS et al, 2006). Além de eliminar diretamente espécies reativas de oxigênio e de nitrogênio 
(ROS/RNS), o ácido ascórbico regenera o $\alpha$-tocoferol e, portanto, participa do mecanismo protetor contra lipoperoxidação (HALLIWELL \& GUTTERIDGE, 1999).

Sendo o uso do ácido ascórbico em formulações cosméticas é inviável devido sua baixa estabilidade em solução aquosa, pois esse sofre oxidação em formulações como: géis, emulsões $\mathrm{O} / \mathrm{A}$, cientistas têm buscado desenvolver derivados do ácido ascórbico com ação similar, mas que apresentem estabilidade química superior e com permeação percutânea equivalente ( MAIA- CAMPOS \& SILVA, 2000).

Dentre os derivados do ácido ascórbico, se destaca o AMS. De acordo com dados da literatura, o AMS apresenta às propriedades cosméticas do ácido ascórbico. Além de ser um antioxidante e despigmentante, o AMS apresenta silício em sua estrutura, assim sua presença em formulações tópicas tem como objetivo repor o silício endógeno, proporcionando a regeneração do tecido (EXSYMOL, 1998). Não há na literatura, até o presente momento, relato que caracterize e analise o AMS.

Sendo assim, faz-se necessário avaliar o AMS empregando-se diferentes técnicas de caracterização. Dentre as técnicas, a análise térmica pode ser aplicada a uma gama extensa de materiais, como polímeros, substâncias sintéticas e naturais, alimentos, fármacos e produtos cosméticos em geral. No desenvolvimento de diversos estudos, podem-se associar várias técnicas termoanalíticas, como por exemplo, a calorimetria exploratória diferencial (DSC) com a termogravimetria (TG), a fim de fornecer resultados complementares, e dependendo de cada caso, pode-se verificar interligações entre essas técnicas termoanalíticas usadas mais amplamente (VELASQUEZ ARMIJO et al, 2004). 
Com base na caracterização das partículas, há a possibilidade do modelamento teórico de materiais. Com o atual avanço nos computadores modernos, cada vez mais é possível a previsão teórica do comportamento e das propriedades dos novos materiais o que diminui e facilita os procedimentos experimentais para o seu desenvolvimento. Para tanto, porém, os dados e as informações que alimentam os modelos propostos devem ter a maior exatidão possível (PAPINI, 2002).

Atualmente, existe um aumento no uso e na mensuração da atividade antioxidante em alimentos, medicamentos e cosméticos. De acordo com BUENGER e colaboradores, os métodos usualmente empregados são o método por DPPH (2,2'difenil-1-picrilhidrazil) e o ORAC (Oxigen Radical Absorbance Capacity Assay). O método de determinação da atividade antioxidante in vitro de compostos, pela reação com DPPH foi inicialmente descrito por Brand-Williams e colaboradores, apresentando como fundamento a redução do radical 2,2' -difenil-1-picrilhidrazil, o qual apresenta um máximo de absorção em 517 nm (BUENGER et al, 2006; BRAND-WILLIAMS et al, 1995). O método da determinação por fluorescência do potencial antioxidante por ORAC baseia-se na análise de solução de fluoresceína, adicionado por uma solução de AAPH (2,2'azobis (2-amidinopropane) dihydrochloride), gerador de radical livre que reage com a fluoresceína, provocando seu consumo (OU, WOODILL HAMPSCH \& PRIOR, 2001)

A nova tendência em formulações cosméticas é a associação de um extrato botânico a vitaminas para aperfeiçoar o seu efeito na pele por efeitos sinérgicos (MAIA - CAMPOS et al, 2006). No presente trabalho, todas as emulsões cosméticas desenvolvidas foram obtidas com base na associação de um extrato botânico ao AMS. 
Sendo que, as emulsões são sistemas termodinamicamente instáveis. As fontes da instabilidade das emulsões são comuns para todos os sistemas dispersos e os agravantes da instabilidade são cremeação, floculação e coalêscencia das gotículas oleosas. Assim, a estabilidade representa um importante fator que pode ser percebido pelo consumidor, sendo que a desestabilização do sistema pode acarretar a perda das propriedades das emulsões (MOSTEFA et al, 2006).

Os métodos cromatográficos são utilizados para identificação e quantificação de substâncias ativas. A avaliação de um componente de uma formulação, em vários intervalos de tempo, revela seu perfil de estabilidade nas condições especificadas (BRASIL, 2004). Na cromatografia de pareamento iônico o pH da fase móvel é ajustado de modo a "encorajar" a ionização da amostra. A retenção é alcançada pela introdução de um reagente de pareamento iônico no eluente, uma molécula orgânica dotada de carga positiva (separação de ácidos) ou de carga negativa (separação de bases). A amostra interage com o contra-íon do pareador e o par iônico formado terá maior afinidade pela coluna de fase reversa em função da hidrofobicidade da cadeia carbônica do reagente pareador (SNYDER, KIRKLAND \& GLAJCH, 1997).

A presente investigação tem as seguintes metas: (a)Caracterizar o AMS empregando diferentes técnicas como: espectrofotometria no ultravioleta, espectrofotometria no infravermelho, cromatografia em camada delgada (CCD), calorimetria exploratória diferencial (DSC), termogravimetria (TG) e análise do tamanho de partícula; (b) Avaliar a atividade antioxidante in vitro do ascorbato de monometilsilanotriol por diferentes técnicas; (c) desenvolver emulsões cosméticas para incorporação do AMS; (d) verificar a estabilidade física dessas formulações e (e) 
desenvolvimento de método analítico para separação e quantificação do AMS, nas formulações cosméticas desenvolvidas. 


\section{REVISÃO DA LITERATURA}

\subsection{Aspectos Gerais sobre a pele}

A pele humana (Figura 1) é o maior órgão do corpo humano, ocupando uma área de mais de $1 \mathrm{~m}^{2}$ de superfície, e corresponde a $20 \%$ do peso corporal. Apresenta-se como um manto de revestimento que isola os componentes orgânicos do meio exterior. É um órgão complexo (MARTINS, 2003). Os aproximadamente 1,80 metros quadrados de pele que revestem a superfície externa do corpo de um adulto médio, sem qualquer ruptura nas várias aberturas do corpo, formam uma barreira protetora dos tecidos mais profundos contra a ação de agentes físicos, químicos e bacterianos (MARTINS, 2003). Uma polegada quadrada de pele contém milhões de células, bem como muitas terminações nervosas cuja finalidade específica é transmitir as sensações de calor, frio e dor. Além disso, cada polegada quadrada contém inúmeras glândulas sebáceas, folículos pilosos e glândulas sudoríparas. Há também uma intrincada rede de vasos sangüíneos que nutrem essa complexa estrutura. (OBAGI, 2004). 


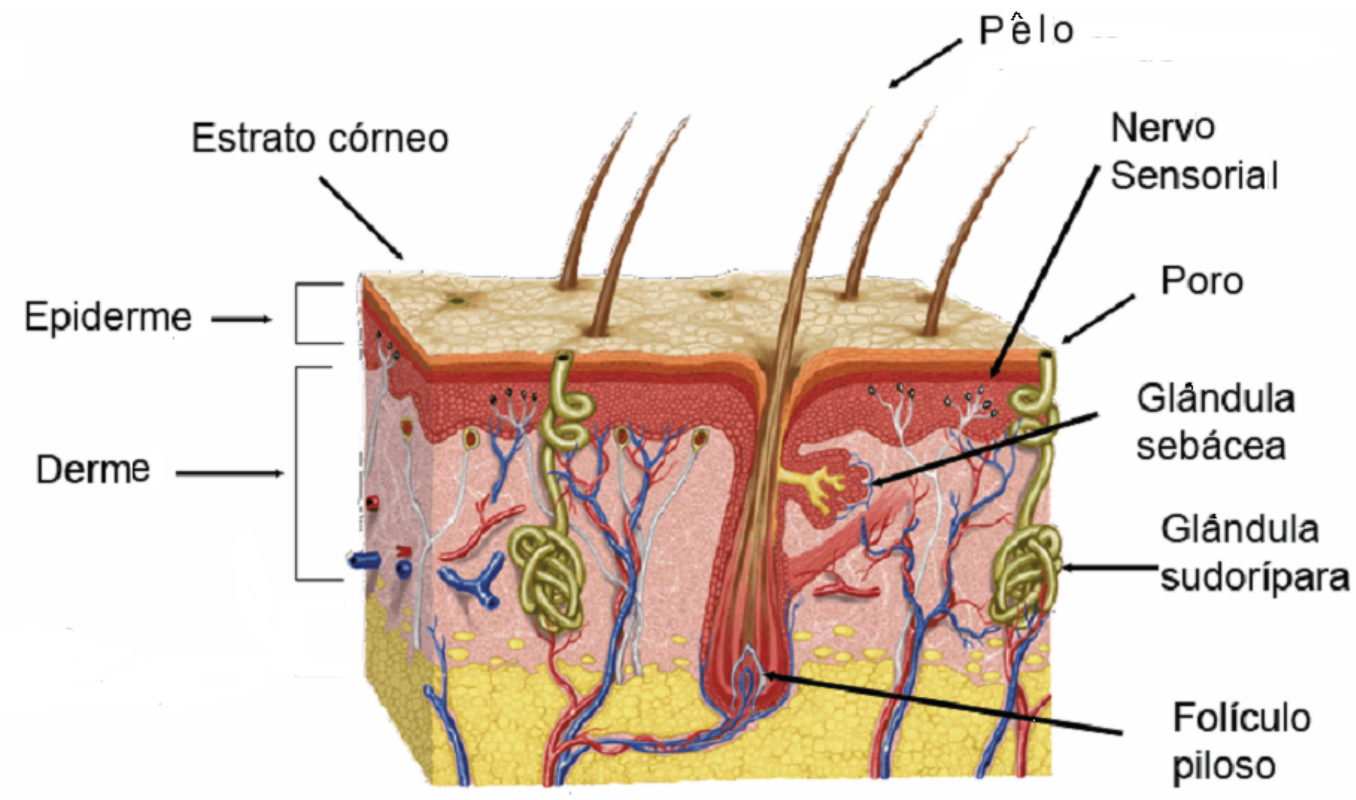

Figura 1. Estrutura esquemática da pele (OBAGI, 2004).

A pele também atua como regulador da temperatura do corpo. Quando o corpo está frio, os vasos sangüíneos se contraem diminuindo o fluxo de sangue através da pele, reduzindo, assim, a perda de calor e mantendo a temperatura normal do corpo. Quando a temperatura do corpo aumenta, esta é diminuída com a dilatação vascular e o aumento do fluxo sangüíneo na superfície da pele. As glândulas sudoríparas, controladas por um centro de controle de calor no cérebro, também participam desse processo. Quando o corpo está quente, suamos e a evaporação do suor na pele esfria a superfície do corpo e ajuda a manter a temperatura normal do corpo. Nesse aspecto, a pele funciona como um órgão excretor, eliminando resíduos inúteis do corpo como, por exemplo, uréia, embora essa excreção seja mínima se comparada com os rins, que realizam a excreção via urina. (KEDE \& SABATOVICH, 2004).

Segundo um estudo realizado por BERADESCA e MAIBACH,uma característica fundamental da raça humana é a cor da pele e o estrato córneo é 
igualmente espesso em negros e brancos, no entanto em negros o estrato córneo contém maior número de camadas de células. Dados do estudo comprovam que a resistência elétrica média de um adulto com pele negra é duas vezes a de um adulto com pele branca, sugerindo um aumento na coesão ou espessamento do estrato córneo. $\mathrm{Na}$ avaliação, foi encontrado o aumento da descamação espontânea em negros. De acordo com o estudo, as diferenças podem estar relacionadas à diferente composição do cimento intercelular do estrato córneo. Foram encontradas também, diferenças significativas na quantidade de ceramidas no estrato córneo, com os níveis mais baixos em negros seguidos por brancos e asiáticos. Os níveis de ceramidas correlacionam-se inversamente com a perda de água transpepidérmica e diretamente com o conteúdo de água (BERADESCA e MAIBACH, 1996).

$\mathrm{O}$ pH da pele (Tabela 1) possui importância fundamental, pois quando se utiliza produtos com $\mathrm{pH}$ parecido ou igual ao da pele, reações alérgicas, irritantes e sensibilizantes são evitadas, diminuindo-se a perda de atividade do produto, obtendo-se melhores resultados (MARTINS, 2003). 
Tabela 1.Variação do pH da pele em partes do corpo humano (MARTINS, 2003).

\begin{tabular}{ll}
\hline Local & pH cutâneo aproximado \\
\hline Axilas & 6,5 \\
Costas & 4,8 \\
Couro-Cabeludo & 4,1 \\
Coxas & 6,1 \\
Intra-vaginal & 6,2 \\
Mãos & 4,5 \\
Nádegas & 6,4 \\
Pés & 7,2 \\
Face & 4,9 \\
Seios & 6,2 \\
Tornozelos & 5,9 \\
Vagina & 4,5 \\
\hline
\end{tabular}

A pele é constituída anatomicamente por três camadas: epiderme, derme e hipoderme; anexos cutâneos; sistema circulatório e músculo (OBAGI, 2004).

\subsubsection{Epiderme}

A epiderme (Figura 2) é um epitélio estratificado pavimentoso, que compreende os queratinócitos, melanócitos, células de Langerhans e células de Merkel. A epiderme subdivide-se em estrato basal, estrato espinhoso, estrato granuloso, estrato lúcido e estrato córneo da derme para a superfície. Sendo o estrato córneo a camada mais importante para a cosmetologia, pois as vias de penetração de cosméticos estão associadas a proteínas e lipídeos do estrato córneo. Localizada na superfície da epiderme, há uma película que recobre a superfície cutânea constituída de uma emulsão de óleos provenientes da secreção sebácea e da queratinização epidérmica e suor, chamada emulsão epicutânea ou manto hidrolipídico que é importante por sua complexidade bioquímica e presença de esqualeno (OBAGI, 2004; MARTINS, 2003). 


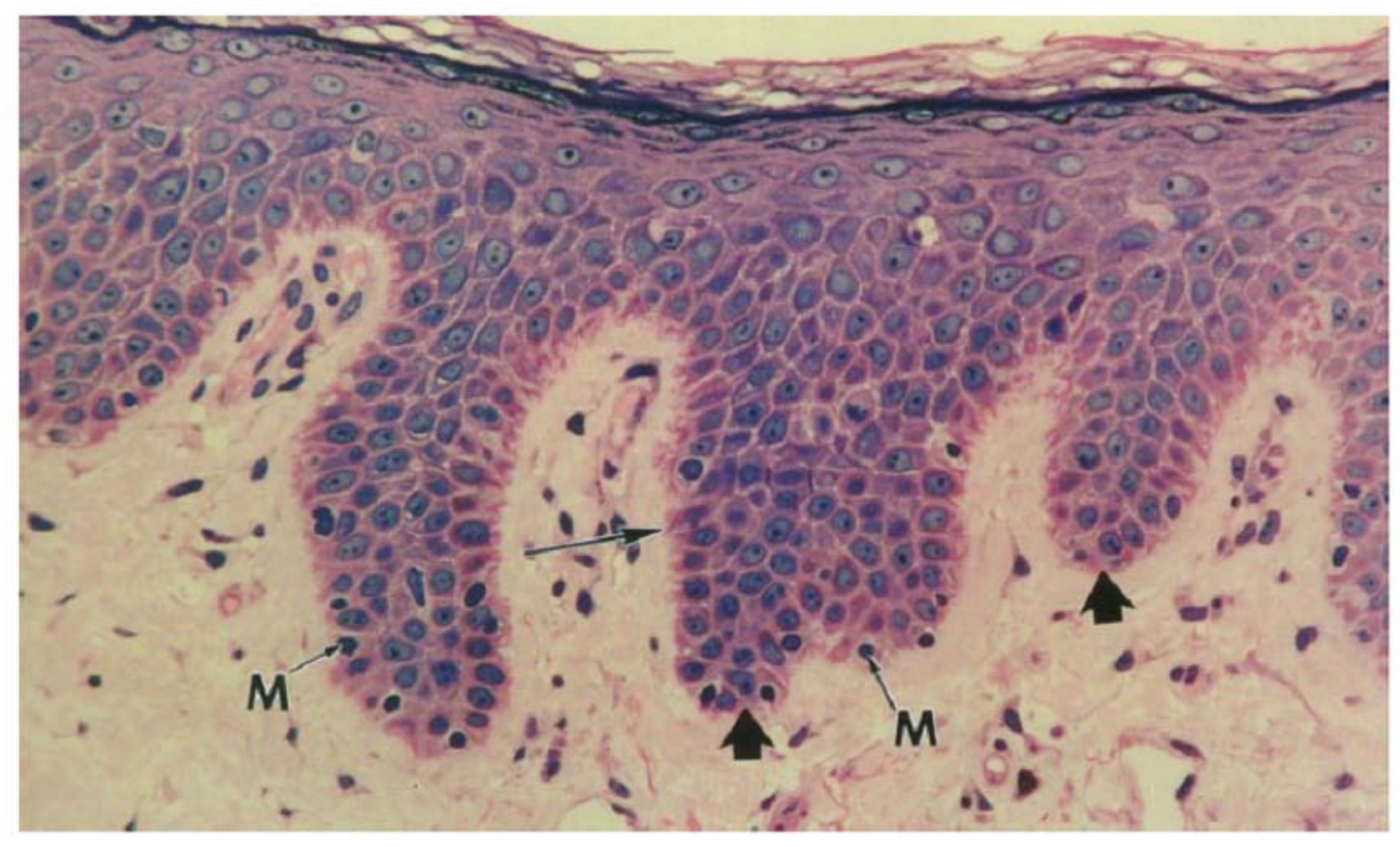

Figura 2. Corte histológico da epiderme (MONTAGNA et al, 1992).

A camada córnea é queratinizada e formada por células poligonais mortas e planas, os corneócitos, com cerca de $1 \mu \mathrm{m}$ de espessura e $40 \mu \mathrm{m}$ de largura, variando o diâmetro e área superficial dependendo da região do corpo, sexo e idade. Essas células são unidas entre si lateralmente por sobreposição de suas imagens com 5 ou 6 corneócitos vizinhos. A camada córnea é o resultado final do processo de diferenciação celular pelo qual passa a epiderme, e que começa na camada germinativa ou na basal, onde muitos filamentos de queratina ou citoqueratina (tonofilamentos) intracelulares são sintetizados e ancorados a superfície das células e tendem a convergir sobre os desmossomas (RIBEIRO, 2002).

Entre a camada córnea e a camada espinhosa da epiderme está à camada granulosa, com espessura de uma ou duas camadas de células. Além dos corpos lamelares, nas células desta região, encontram-se grânulos de querato-hialina, que são pequenos corpúsculos arredondados ou ovais com tamanhos variados, compostos de material protéico rico em aminoácidos com enxofre como a cisteína. (RIBEIRO, 2002) 
A camada espinhosa é formada por várias fileiras de células que se encontram unidas por desmossomas, que são junções celulares de adesão. Os queratinócitos espinhosos também abrigam as tonofibrilas. Entre as células espinhosas encontram-se as células de Langerhans, que apresentam em sua superfície receptores para IgE (imunoglobulina E) que captam antígenos exteriores (OBAGI, 2004).

Abaixo da camada espinhosa está à camada basal que dá suporte a epiderme e estabelece a união com a derme. Estruturas conhecidas como hemidesmossomas, complexos juncionais especializados, fornecem fixação estável dos queratinócitos basais à membrana basal. É nesta região que se observa maior proporção de células em divisão, todavia cima da mesma é possível verificar células em mitose (MARTINS, 2003).

\subsubsection{Derme}

A derme (Figura 3) é a camada intermediária formada de tecido conjuntivo de apoio da epiderme, é composta por colágeno e elastina juntamente com uma substância denominada substância fundamental e é subdividida em: derme superficial ou papilar (Figura 4) e derme profunda ou reticular (Figura 5) (OBAGI, 2004; MARTINS, 2003). 


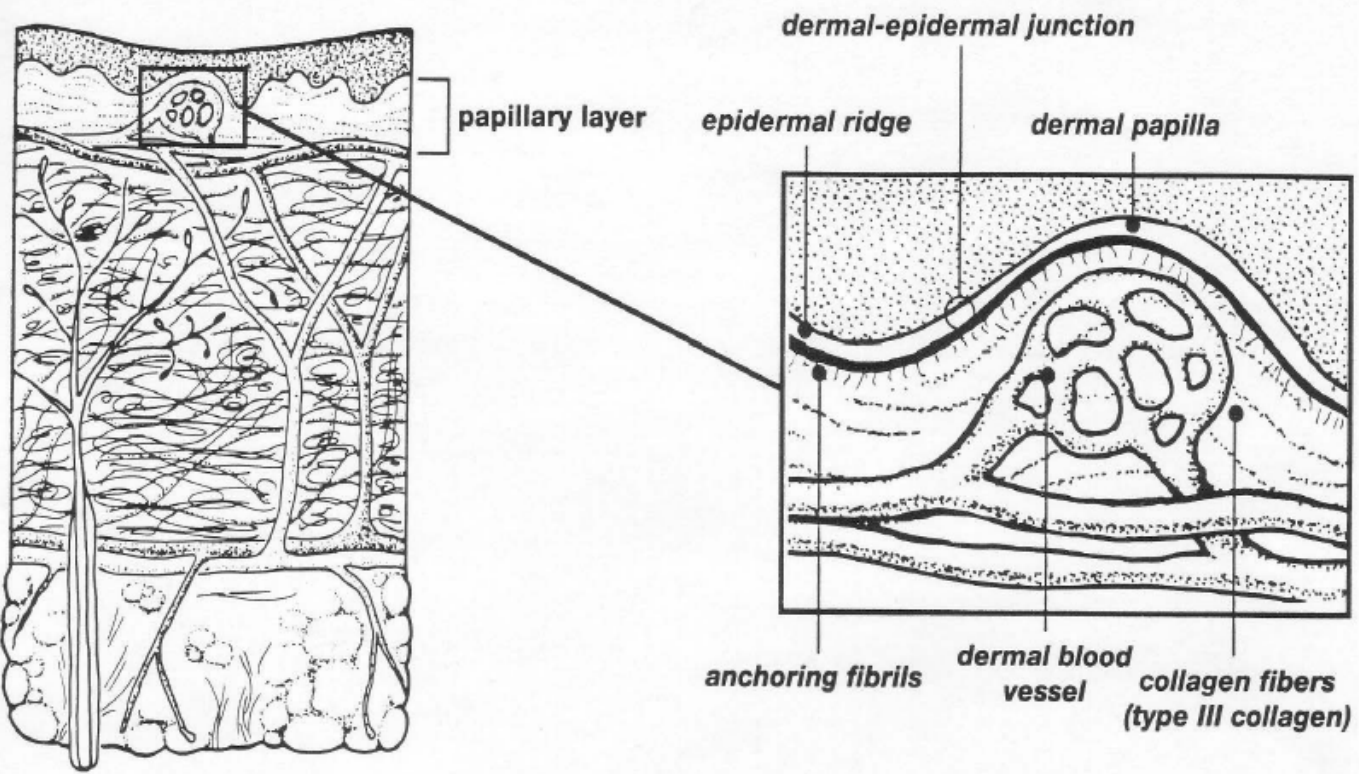

Figura 3. Esquema ilustrativo da derme ( MONTAGNA et al, 1992).

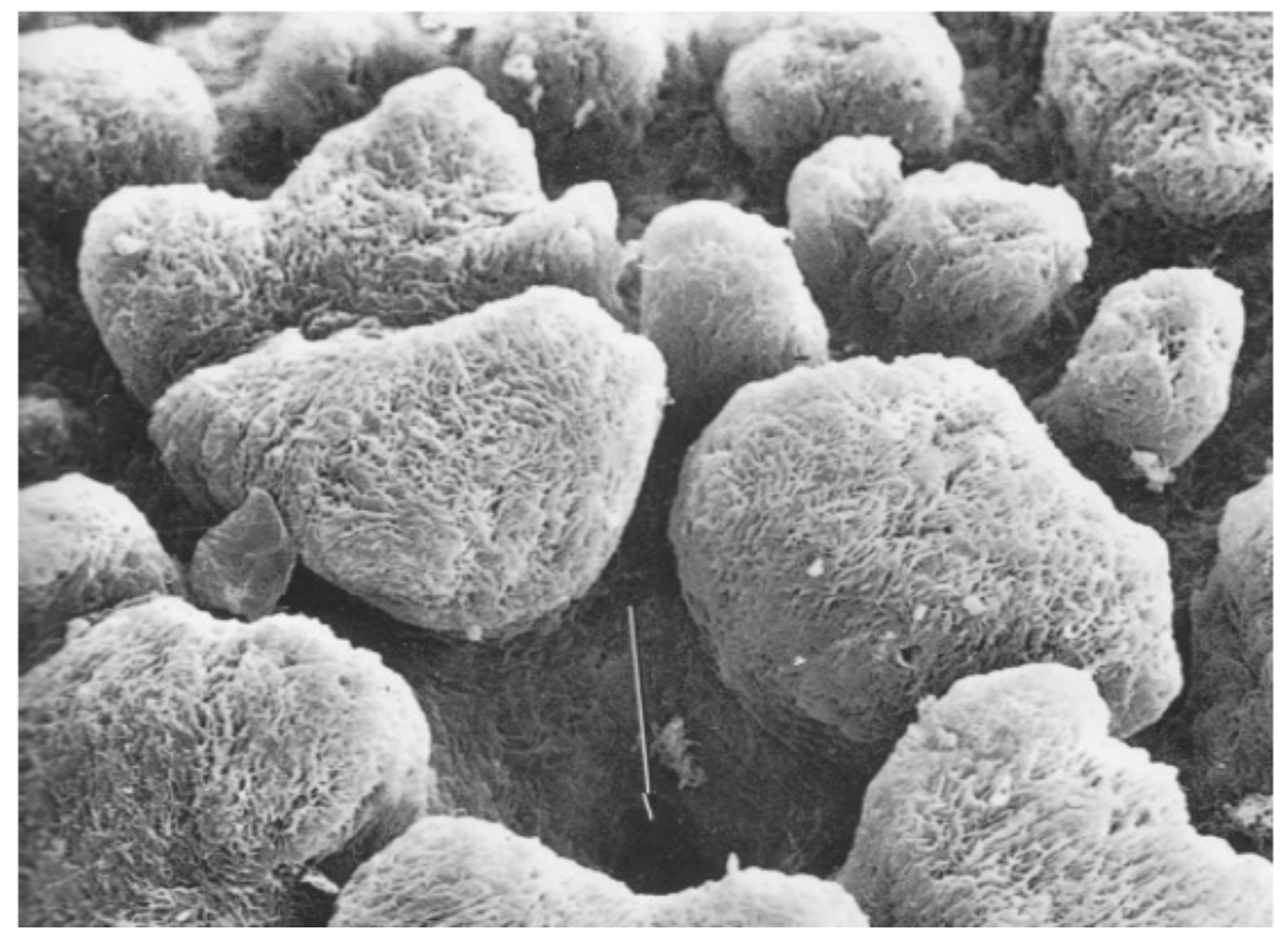

Figura 4. Superfície da derme papilar (MONTAGNA et al, 1992). 


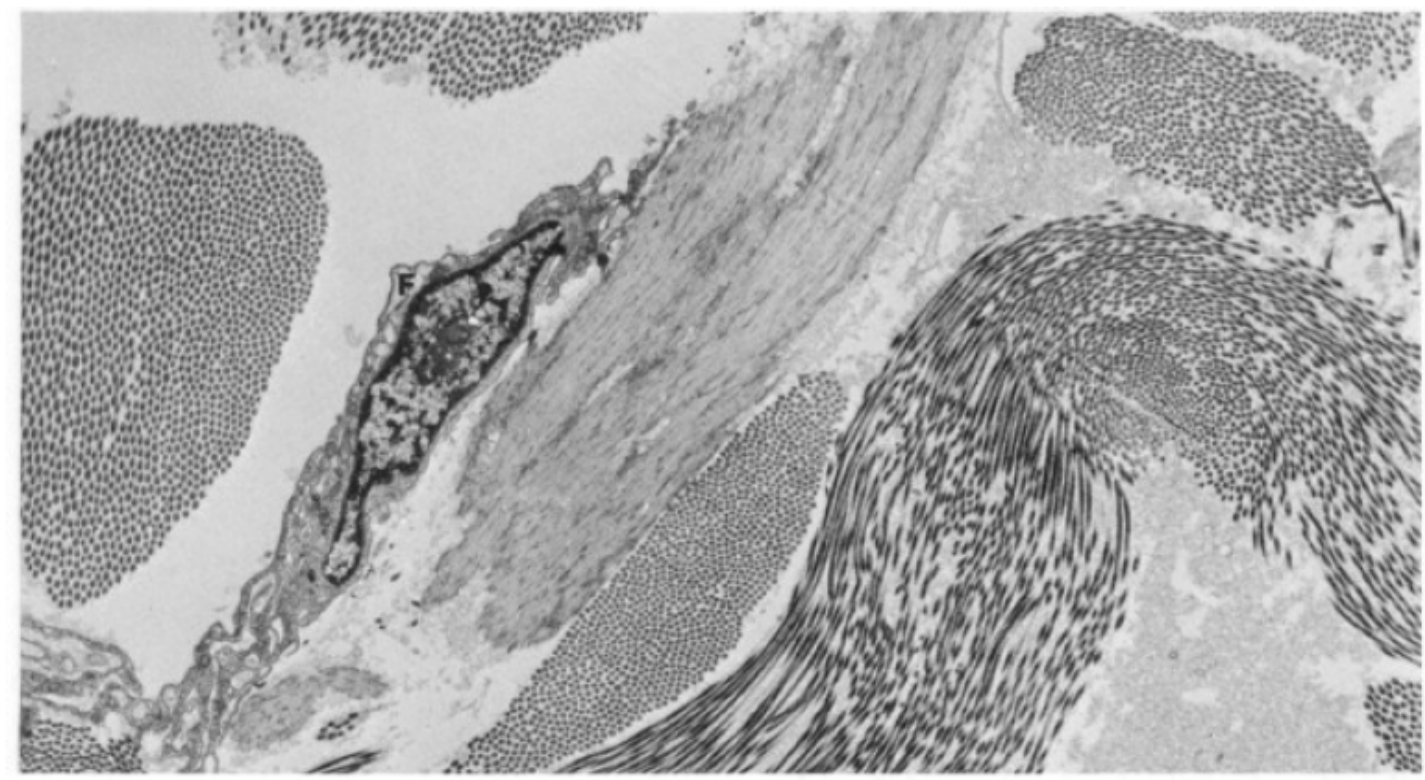

Figura 5. Ilustração da derme reticular (MONTAGNA et al, 1992).

\subsubsection{Melanina}

A melanina é um termo genérico empregado para descrever um grupo diversificado de biopolímeros heterogêneos, pigmentados, polifenólicos de alto peso molecular. Apesar de possuírem precursores semelhantes e de uma fenoxidase nos estágios iniciais de síntese, as melaninas possuem origem, composição química e propriedades físicas diversas. Ocorrem nos tecidos vivos na forma insolúvel e são encontradas praticamente em todos os organismos vivos (SILVA, 1998).

Nos seres humanos a melanina é produzida pelas células dendríticas especializadas, os melanócitos (Figura 6), responsáveis pela coloração da pele, cabelo e olhos. Os melanócitos absorvem a luz visível e a ultravioleta (UV), protegendo a pele contra danos provocados pelas radiações, especificamente as radiações ultravioleta A e B (UVA-UVB) (SCOTTI \& VELASCO, 2003; THIBODEANS, 2004). 


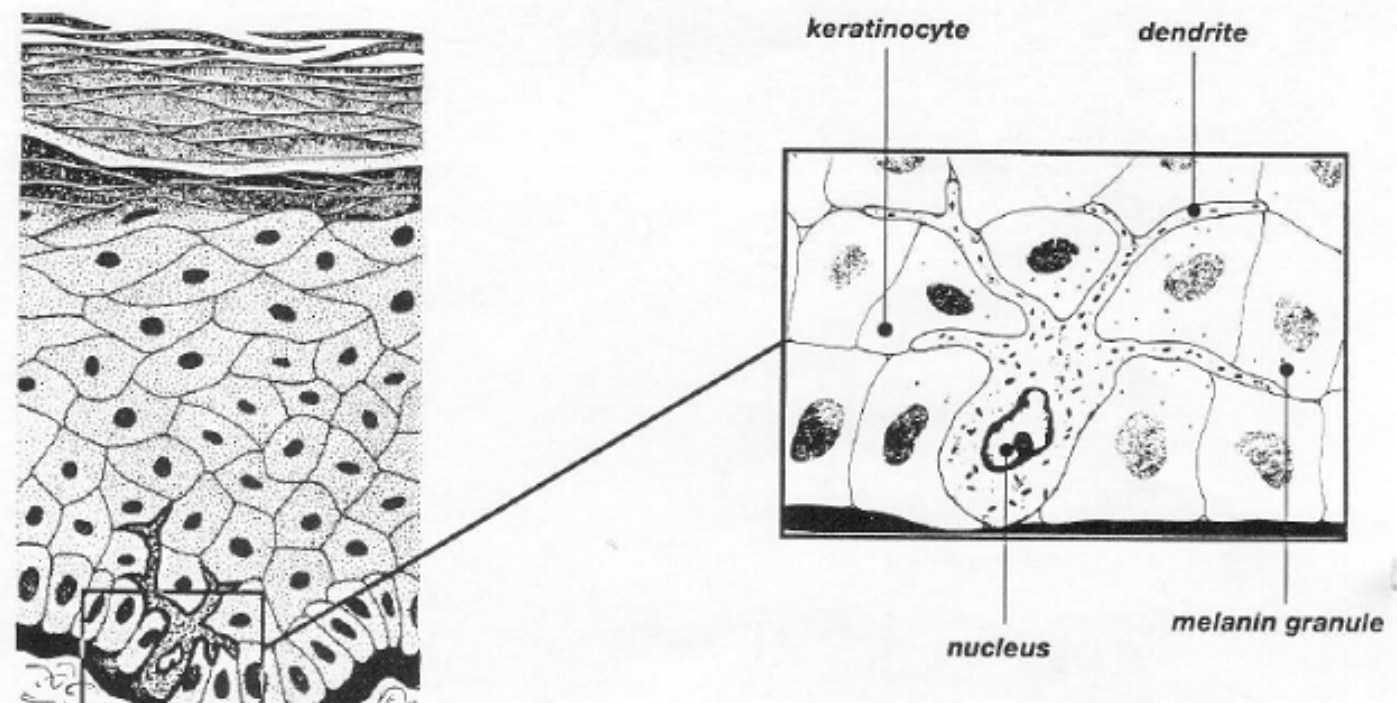

Figura 6. Esquema do melanócito na epiderme (MONTAGNA et al, 1992).

\subsubsection{Classificação:}

A melanina é classificada em:

\section{A. Eumelanina}

Pigmento insolúvel, de coloração variável de marrom a preto, contendo pequena quantidade de enxofre. É um biopolímero com estrutura indol, produzido pela co-polimerização da dopa-oxidase e de seus produtos de ciclização, particularmente 5,6dihidroxiindol (DHI) e 5,6-dihidroxiindol-2-ácido carboxílico (DHICA). É uma substância resultante da polimerização oxidativa de compostos indólicos derivados da dihidroxifenilalanina (NOGUEIRA, 2002; THIBODEANS, 2004; WILKSON \& MOORE , 1990; OLIVEIRA \& ALMEIDA, 2003).

\section{B. Feomelanina}

Pigmento heterogêneo, de coloração variável de amarelo a marrom avermelhado e sintetizado a partir de tirosina e cisteína. É solúvel em álcalis e resulta da 
polimerização da cisteinildopa e produtos de ciclização, particularmente 1,4benzotiazina. Degradada facilmente pela radiação ultravioleta, é menos fotoestável do que a eumelanina (NOGUEIRA, 2002; THIBODEANS, 2004; WILKSON et al, 1990; OLIVEIRA \& ALMEIDA, 2003).

Raramente a feomelanina e a eumelanina são encontradas na forma isolada, pois durante a melanogênese formam-se melaninas em diferentes proporções, o que explica as diferentes tonalidades de cores que ocorrem na natureza (HERNANDEZ \& FRESNEL, 1999).

Além desses tipos de melaninas (Tabela 2), existem outros tipos como as alomelaninas, presentes em plantas, fungos e bactérias e ainda a neuromelanina, presente em neurônios de núcleos cerebrais como, por exemplo, a substância nigra (HERNANDEZ \& FRESNEL, 1999).

Tabela 2. Tabela de variações na pigmentação entre as três raças maiores (HERNANDEZ \& FRESNEL, 1999).

\begin{tabular}{|c|c|c|}
\hline RAÇA & MELANINA & INFORMAÇÕES \\
\hline CAUCASIANA & Eumelanina & Os melanossomos são \\
\hline & & $\begin{array}{l}\text { identificados na camada } \\
\text { granulosa pelo tipo monglóide } \\
\text { e são destruídos antes pelo tipo } \\
\text { caucasiano. }\end{array}$ \\
\hline NEGRÓIDE & Eumelanina & $\begin{array}{l}\text { Os melanossomos são } \\
\text { de grandes tamanhos e muito } \\
\text { numerosos nos melanócitos. } \\
\text { Chegam intactos à camada } \\
\text { córnea. }\end{array}$ \\
\hline CÉLTICA & Feomelanina & $\begin{array}{l}\text { Os melanossomos } \\
\text { estão ainda presentes no nível } \\
\text { da camada filamentosa de } \\
\text { Malpighi. }\end{array}$ \\
\hline
\end{tabular}




\subsubsection{Melanócitos}

Na pele normal os melanócitos são encontrados apenas na camada basal. Eles estão dispersos entre os queratinócitos dessa camada. Por meio de prolongamentos de seu citoplasma, chamados processos dendríticos, cada melanócito está em contato com 30 a 40 queratinócitos (Figura 7). Os melanócitos não possuem tonifibrilas, nem junções desmossômicas com as células adjacentes (NOGUEIRA, 2002; THIBODEANS, 2004; WILKSON \& MOORE, 1990; OLIVEIRA \& ALMEIDA, 2003).

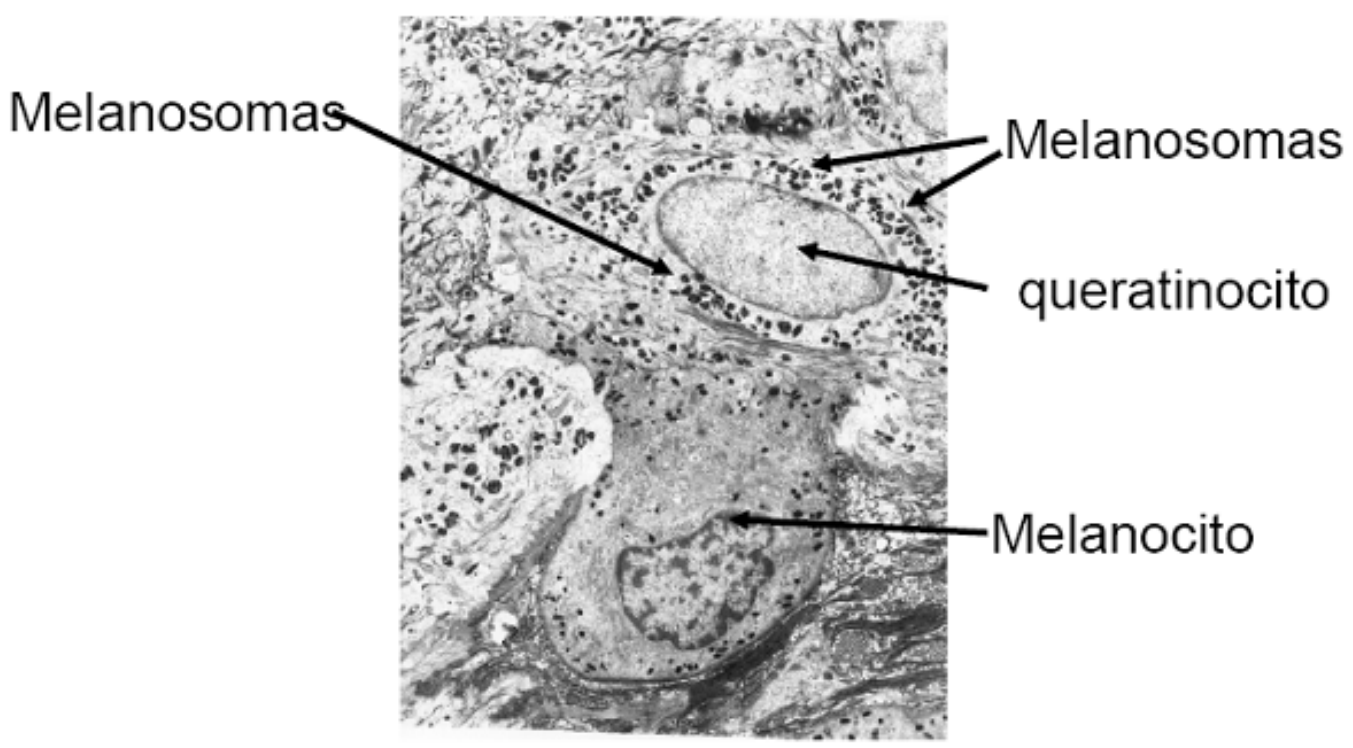

Figura 7. Micrografia do melanócito em contato com o queraticnócito e melanossomas transferidos (MONTAGNA et al, 1992). 
Os melanócitos localizados na camada basal da epiderme e folículo pilo-sebáceo produzem e secretam, continuamente, a melanina para os queratinócitos, sendo essa atividade diminuída gradativamente com o envelhecimento do indivíduo (NOGUEIRA, 2002; THIBODEANS, 2004; WILKSON \& MOORE, 1990; OLIVEIRA \& ALMEIDA, 2003). Na Figura 8, pode-se observar a diferença dos melanócitos da pele escura dos melanócitos da pele clara.
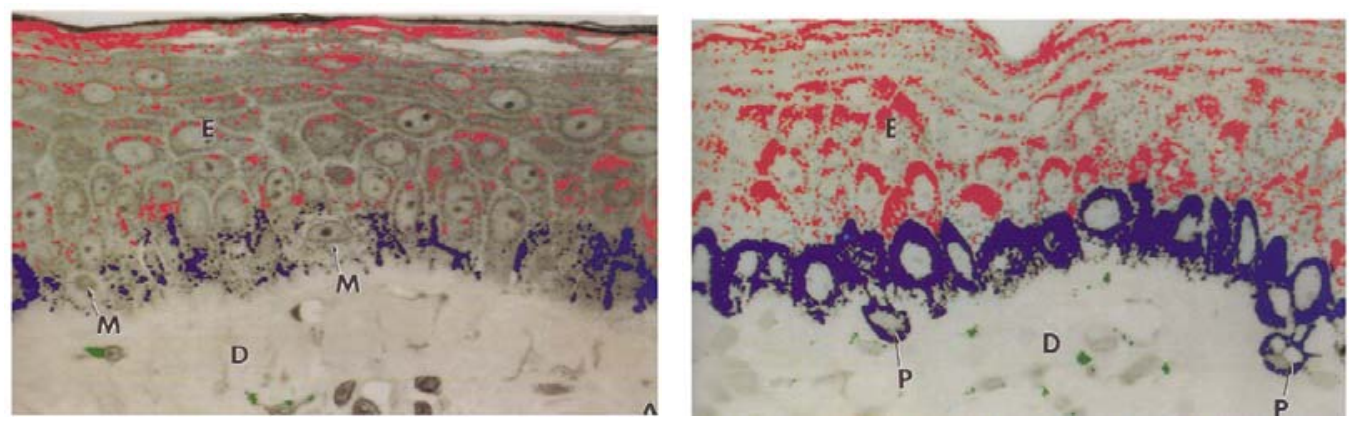

Figura 8. Fotomicrografias dos melanócitos de pele clara e escura respectivamente.

Na camada basal da epiderme, o número de melanócitos varia de 2000 a 2500 por $\mathrm{mm}^{2}$, nas regiões expostas à luz e genitais e no resto do corpo de 1000 a 1500 por $\mathrm{mm}^{2}$ (WILKSON \& MOORE, 1990).

\subsubsection{Melanogênese}

A melanina é sintetizada em organelas celulares denominadas melanossomos a partir de um precursor comum, a tirosina. A síntese melânica é estimulada principalmente pela radiação UV (NOGUEIRA, 2002).

A síntese da melanina (Figura 9) começa com a oxidação enzimática de Ltirosina à L-dopa a dopaquinona e ocorre em aerobiose. Com a transformação 
espontânea da dopaquinona em leucodopacromo e dopacromo inicia-se uma cascata bioquímica, a qual termina com a formação de pigmento da eumelanina. A conjugação de dopaquinona com cisteína ou glutationa resulta em cisteinildopa e glutationildopa. Ambos passam por uma série de transformações, gerando a feomelanina. Além destas enzimas, fatores não enzimáticos interferem na síntese do pigmento, tais como $\mathrm{pH}$, concentrações de tiois e íons metálicos ou oligoelementos como o $\mathrm{Ca}^{++}$(NOGUEIRA, 2002; THIBODEANS ，2004; WILKSON \& MOORE, 1990; OLIVEIRA \& ALMEIDA, 2003).

A tirosinase é uma cuproteína que contém uma fração glicídica (ácido neurâmico e galactose) que controla o processo melanogênico. É sintetizada na superfície do retículo endoplasmático rugoso e depois transferida para o complexo de Golgi associada com o lisossomo, no qual é ativada pela adição de uma cadeia de açúcar, antes de ser secretada em vesículas. Um pré-melanossomo liberado do complexo de Golgi funde-se com a vesícula para formar o melanossomo. (NOGUEIRA, 2002; THIBODEANS, 2004; WILKSON \& MOORE, 1990; OLIVEIRA \& ALMEIDA, 2003). 


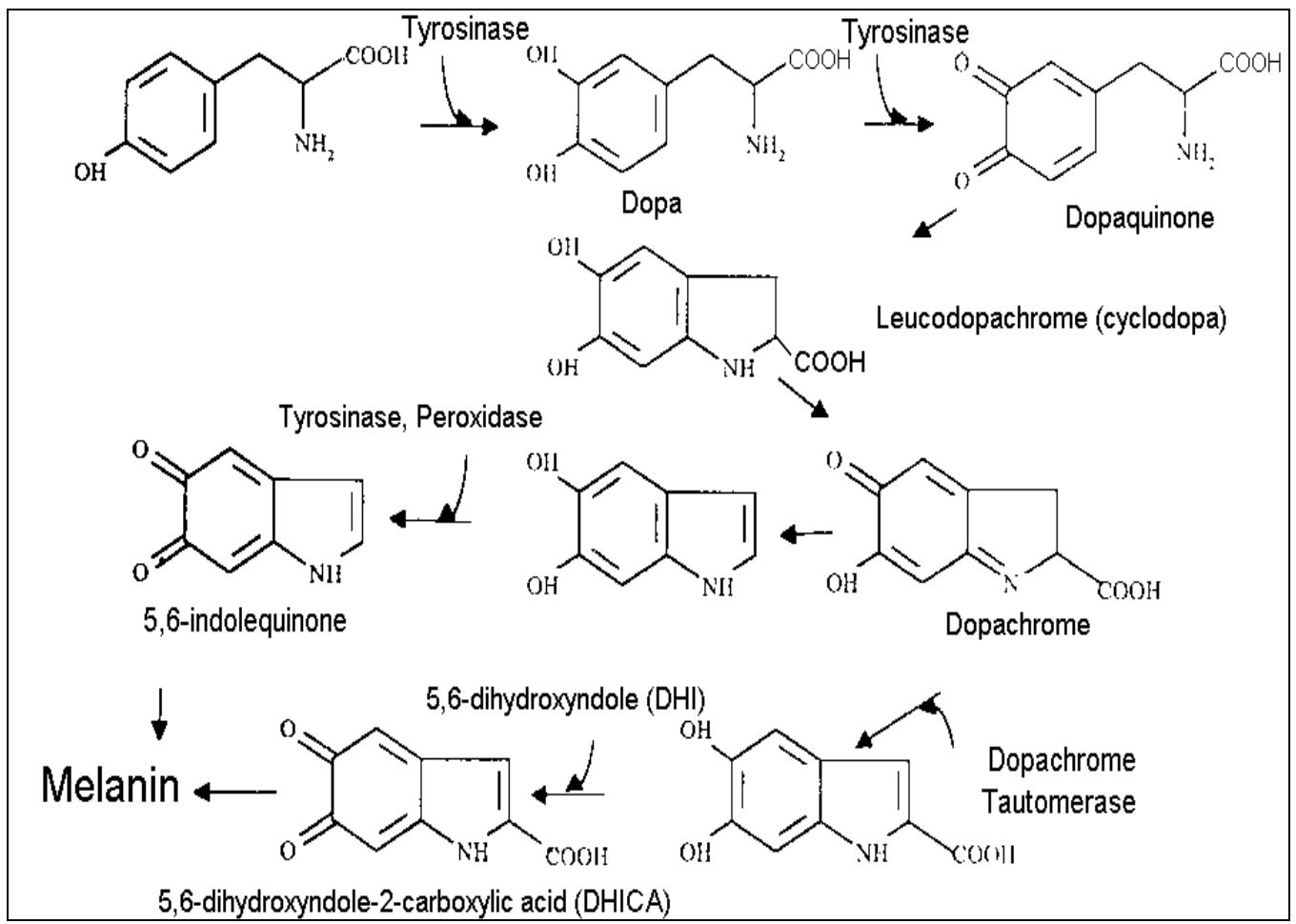

Figura 9. Etapas químicas da melanogênese (WILKSON \& MOORE, 1990).

\subsubsection{Alterações na pele}

\subsubsection{Fatores que afetam a pigmentação}

Os fatores que afetam a pigmentação da pele são os fatores genéticos, hormonais e ação dos raios UV. Sendo que, todos os estágios da melanogênese estão sob controle genético. As características dos melanossomas são codificadas pelos genes de pigmentação. A gravidez e a ingestão de anticoncepcionais vão produzir uma mudança na coloração da epiderme. O hormônio hipofisário MSH (melanocyte stimulating hormone), estimula a melanogênese. Os estrógenos e a progesterona provocam a hiperpigmentação do rosto e da epiderme genital. E em relação à ação dos raios UV é válido salientar que a ação dos raios UVB, multiplica os melanócitos ativos e estimula a tirosinase. A produção aumentada de melanina é uma reação defensiva da pele, promovendo a formação do eritema actínico (NOGUEIRA, 2002; THIBODEANS, 2004; WILKSON \& MOORE, 1990; OLIVEIRA \& ALMEIDA, 2003). 


\subsubsection{Envelhecimento Cutâneo}

O envelhecimento pode ser definido como sendo um conjunto de alterações morfológicas, fisiológicas e bioquímicas inevitáveis que ocorrem progressivamente no organismo ao longo da vida. Essas alterações levam à perda gradativa das funções dos vários órgãos que formam o organismo humano, entre ele a pele, aumentando a vulnerabilidade ao meio ambiente e diminuindo a sua capacidade de homeostasia (RIBEIRO, 2006).

Mudanças nas características da pele humana durante o envelhecimento são freqüentemente determinadas por forças ambientais ou extrínsecas, tais como radiação ultravioleta, assim como por fatores intrínsecos, alguns deles relacionados com alterações no tecido conjuntivo da derme. Alterações no tecido conjuntivo, que atua como alicerce estrutural para epiderme, delineiam essas mudanças na aparência externa, que são refletidas no estrato córneo. As modificações do aparelho colágeno-elástico ao longo da vida estabelecem uma base morfológica substancial para compreender as adaptações bioquímicas e biomecânicas da pele com a idade. A espessura da pele e suas propriedades viscoelásticas não dependem apenas da quantidade de material presente na derme, mas também de sua organização estrutural (ORIÁ et al, 2003).

Durante sua vida o indivíduo sofre diversas agressões por agentes físicos, químicos ou biológicos, que podem levar ao aparecimento de patologias ou alterar o processo de envelhecimento. Os tecidos gradualmente passam por mudanças de acordo com a idade, sendo que, na pele, essas alterações são mais facilmente reconhecidas. Atrofia, enrugamento e lassidão representam os sinais mais aparentes de uma pele senil (ORIÁ et al, 2003). O envelhecimento intrínseco da pele é observado na epiderme como um reflexo das modificações que ocorrem também no tecido conjuntivo da derme, que 
atua como um alicerce natural para a epiderme. Na epiderme, nota-se a diminuição das células de Langherans e monócitos, diminuição da síntese de melanossomas e menor pigmentação. Na derme, observa-se a diminuição do colágeno, fibras elásticas, macrófagos e dilatação dos canais linfáticos. As mudanças fisiológicas observadas são a diminuição do número de queratinócitos e fibroblastos e redução da vascularização, principalmente próximo aos folículos pilosos e glândulas (OBAGI, 2004; ORIÁ et al, 2003). A Figura 10 mostra a diferenciação histológica de pele jovem e envelhecida intrinsecamente. Sendo assim, observa-se a clara fragmentação das fibras elásticas ao longo da derme com o envelhecimento. Na derme superficial, o aparelho elástico perdeu quase completamente sua disposição vertical na pele senil.

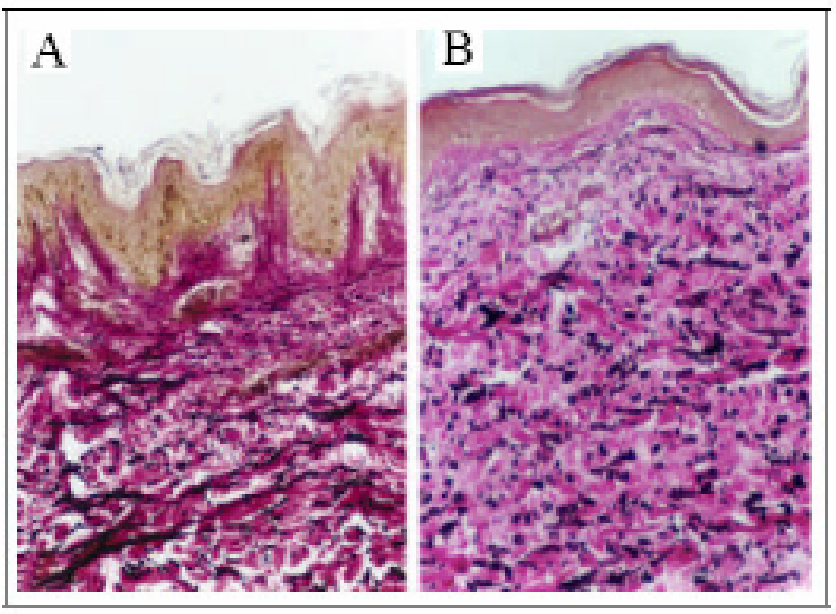

Figura 10. Diferenciação histológica de pele jovem e envelhecida intrinsecamente. Espécimes de pele dos grupos jovem (A) e idoso (B) corados pelo tricrômio de Van Gieson-elastina, em que as fibras elásticas são observadas em preto (ORIÁ et al, 2003).

Com o passar dos anos e principalmente após os 30 anos de idade, surgem rugas, manchas de hiperpigmentação, redução na espessura da pele e dificuldade de cicatrização. O envelhecimento cutâneo devido a fatores externos e principalmente 
influenciado pela radiação solar é conhecido como envelhecimento extrínseco ou actínico.

\subsection{Radiação solar e fotoenvelhecimento}

Os principais raios emitidos pelo sol na região ultravioleta são: UVC ( 200 290nm), UVB (290-320 nm) e UVA ( 320 - $400 \mathrm{~nm})$ (OLIVEIRA \& ALMEIDA, 2003; SILVA, 1998).

A radiação ultravioleta pode apresentar tanto efeitos danosos quanto benéficos para a pele humana. Os efeitos benéficos compreendem a indução da síntese da vitamina $\mathrm{D}$ por tratar certas doenças de pele assim como a psoríase vulgaris (MATSUMURA \& ANANTHASWAMY, 2002; MORGANTI \& FABRIZI, 2002). Os efeitos danosos da radiação ultravioleta são muitos, tais como: imunossupressão, fotoenvelhecimento e carcinogênese. A fotocarcinogênese envolve o acúmulo de mudanças genéticas bem como a modulação do sistema imune e conduz ao desenvolvimento do câncer de pele.

A exposição solar excessiva pode causar diversos danos ao organismo, dentre eles, imunossupressão local e sistêmica, fotoenvelhecimento precoce e, como principal fonte de preocupação, o aparecimento de fotocarcinogênese (DECCACHE, 2006; OBAGI, 2004). O fotoenvelhecimento da pele é um processo complexo que se caracteriza pela perda do tônus cutâneo, aumento da desidratação e ressecamento, elastose actínica, pigmentação irregular e aparecimento de rugas mais profundas. Esse fenótipo é causado por alterações nas funções celulares e deterioração da matriz extracelular dos tecidos conectivos, levando a uma desorganização das proteínas estruturais primárias como elastina e colágeno (SCOTTI \& VELASCO, 2003; OBAGI, 2004; DECCACHE, 2006). Bioquimicamente a pele fotodanificada apresenta 
modificações quantitativas e qualitativas nas proteínas da matriz dérmica extracelular, entre elas colágeno, glicosaminoglicanos e elastina (ORIÁ et al., 2003). As metaloproteinases de matriz (MMPs) são uma família de enzimas capazes de degradar a maior parte dos componentes conectivos e proteínas da matriz dérmica. Estudos demonstraram uma relação dose-dependente entre as MMPs e a radiação UVA e UVB (DECCACHE, 2006).

As alterações histológicas que a irradiação ultravioleta pode provocar são: espessamento do estrato córneo, epiderme e derme. Sendo que, a hiperplasia resulta no aumento da epiderme e da atividade mitótica. Todas as mudanças histológicas mencionadas são temporárias e após evitar a exposição aguda ao UV a célula retorna ao normal dentro de 1-2 semanas (MATSUMURA \& ANANTHASWAMY, 2002; MORGANTI \& FABRIZI, 2002). Na Figura 11, pode-se observar os efeitos causados pela radiação UV. 


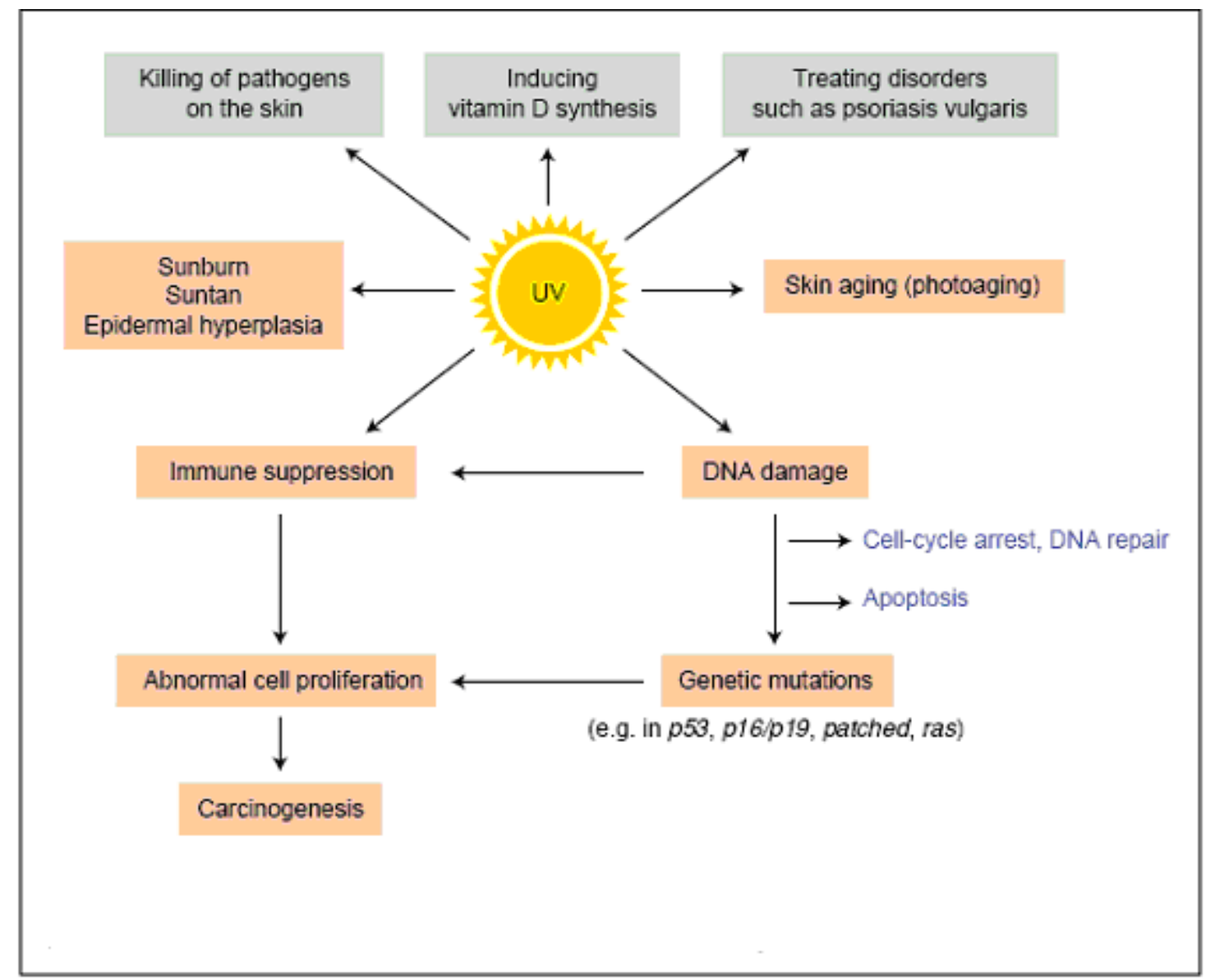

Figura 11. Efeitos da radiação UV na pele (MATSUMURA \& ANANTHASWAMY, 2002).

De acordo com SCOTTI \& VELASCO, 2003 os danos provocados nas fibras de colágeno pela radiação UVA, quando comparados aos do UVB são maiores, entretanto, após irradiação, ambas influenciam na atividade prostaglandina e interleucina, além de provocar diminuição de células de Langerhans. A radiação UVB causa uma resposta inflamatória maior, ativando macrófagos e neutrófilos que secretam enzimas proteolíticas capazes de hidrolisar o colágeno.

A radiação UV (Figura 12) é responsável por 90\% dos danos causados a pele. A radiação UVB é suficientemente energética para penetrar no estrato córneo e epiderme causando queimaduras severas ou eritemas. A radiação UVA alcança a derme 
estimulando a formação de melanina a qual protege a pele de queimaduras imediatas. No entanto, embora os raios UVA possuam menor energia que os raios UVB, os raios UVA penetram na derme causando também elastose, isto é, a perda das estruturas de suporte natural e elasticidade da pele (DECCACHE, 2006; OLIVEIRA \& ALMEIDA, 2003).

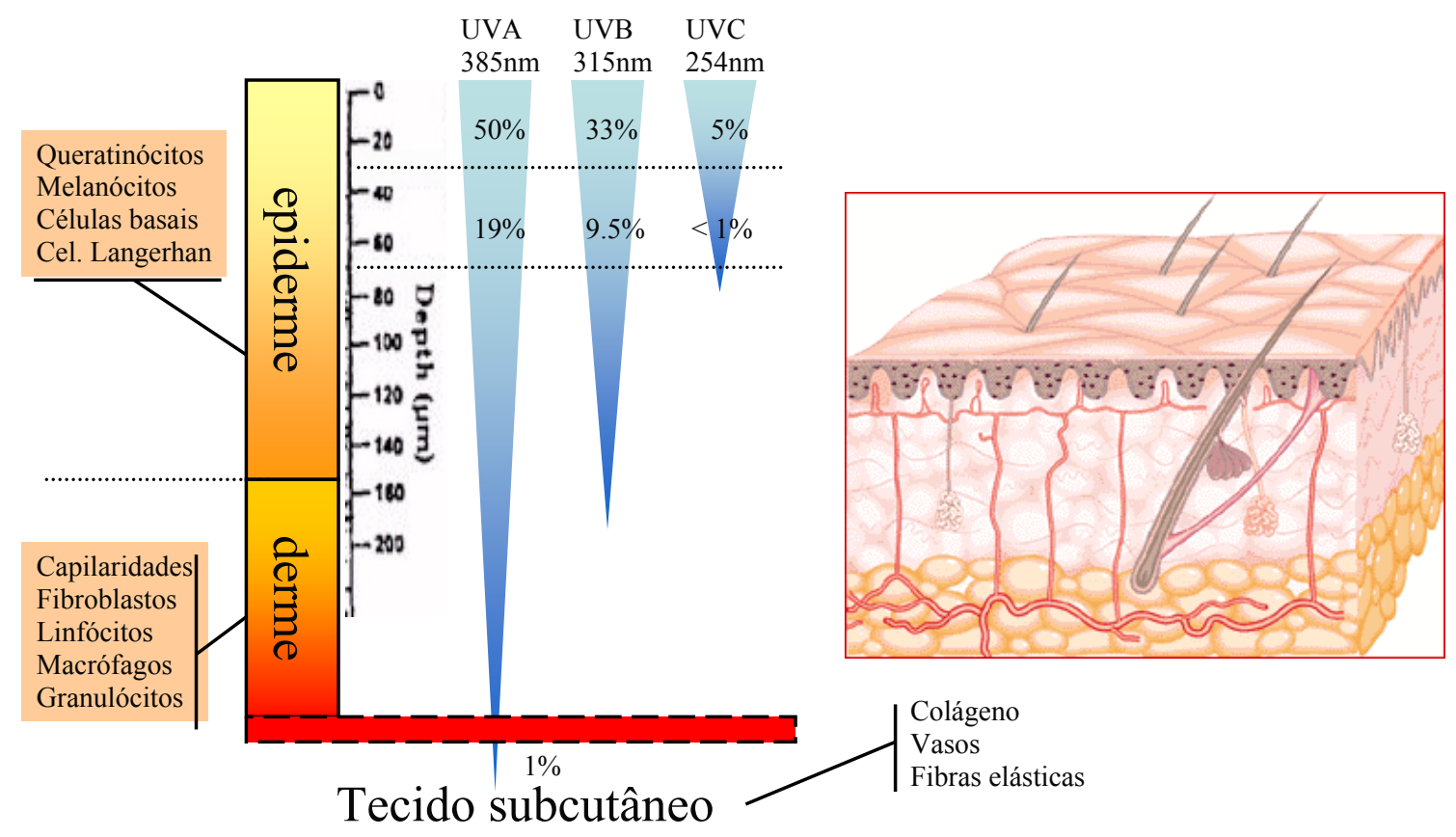

Figura 12. Penetração da radiação solar na pele (Adaptado: OLIVEIRA et al, 2003).

\subsection{Cosméticos}

\subsubsection{Definições de cosméticos}

De acordo com a Resolução RDC n ${ }^{0}$ 211, de 14 de julho de 2005 da Agência Nacional de Vigilância Sanitária (ANVISA); cosméticos, produtos de higiene pessoal e perfumes são preparações constituídas por substâncias naturais ou sintéticas, de uso externo nas diversas partes do corpo humano, pele, sistema capilar, unhas, lábios, 
órgãos genitais externos, dentes e membranas mucosas da cavidade oral, com o objetivo exclusivo ou principal de limpá-los, perfumá-los, alterar sua aparência e ou corrigir odores corporais e ou protegê-los ou mantê-los em bom estado (BRASIL, 2005).

Para o Food and Drug Administration (FDA) cosméticos são produtos que, quando aplicados no corpo humano, limpam, embelezam, promovem atratividade ou modificam a aparência da pele e cabelos ou do corpo, sem afetar a sua estrutura ou função. Produtos identificados como cosméticos, mas que tratam ou previnem doenças ou, ainda, que afetam a estrutura ou função da pele humana são considerados, pelo FDA, como fármacos, e devem seguir o estatuto de medicamentos. Esses produtos, conhecidos como Over the Counter (OTC) que significa "sobre o balcão", integram alguns produtos considerados cosméticos na Europa e Brasil e se referem a produtos considerados medicamentosos que podem ser comercializados sem a necessidade de prescrição médica (RIBEIRO, 2006).

Os componentes de um produto cosmético devem estar descritos nos compêndios técnicos da International Cosmetics Ingredients (INCI) garantindo, assim, uma maior segurança. Não devem apresentar nenhum risco à saúde humana nas condições de uso preconizadas ou razoavelmente previsíveis (RIBEIRO, 2006).

\subsubsection{Emulsões}

Dentre inúmeros veículos utilizados para formulações com ativos cosmetológicos, a emulsão (Figura 13) faz parte de um grupo de veículos que apresentam boa aceitação por parte dos consumidores. É resultante da dispersão de uma fase interna formada por gotículas ou glóbulos de um líquido distribuídos em um veículo no qual é imiscível, a fase externa, empregando um sistema tensoativo. Trata-se de uma mistura termodinamicamente instável, exigindo criterioso estudo de sua 
estabilidade física, química e físico-química que dará indicações sobre o seu comportamento e desempenho no decorrer de determinado intervalo de tempo (prazo de validade). As informações obtidas no estudo de estabilidade são particularmente importantes para os veículos emulsionados, pois quando estocados podem gerar sinais de desestabilização como: cremeação, sedimentação, floculação, coalescência e, por fim, separação de fases (RANGEL, BOSCHETTI \& UEMA, 2004; BABY et al, 2004; ANSEL, POPOVICH \& ALLEN, 2000; HAMEYER \& JENNI, 1996).

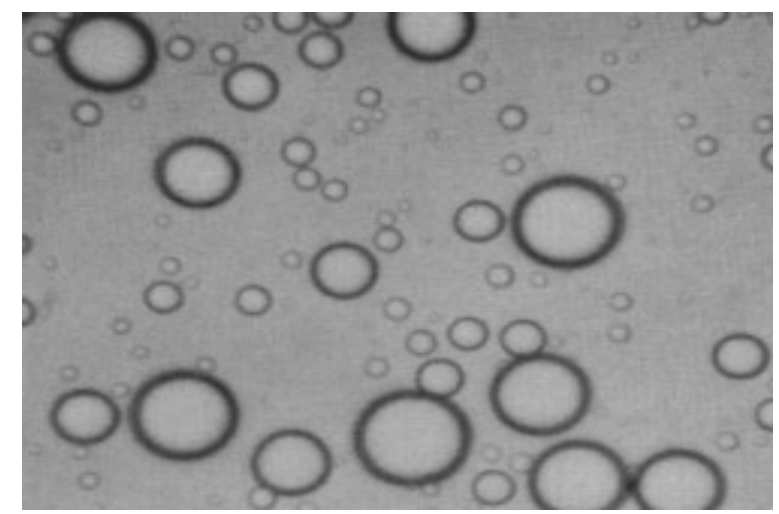

Figura 13. Óleo mineral em emulsão aquosa (ANSEL, POPOVICH \& ALLEN, 2000).

Considerando as fases contínuas e descontínuas de uma emulsão simples, classificamos como tipo óleo-em-água (O/A), aquela em que o óleo constitui a fase dispersa, interna ou descontínua e a água, a fase dispersante, externa ou contínua; caso ocorra a água como fase dispersa, serão obtidas emulsões do tipo (A/O). As emulsões do tipo $\mathrm{O} / \mathrm{A}$ são quantitativamente mais utilizadas devido ao seu aspecto menos oleoso e mais agradável para aplicação tópica (SILVA \& SOARES, 1996).

A subdivisão das fases em gotículas e a formação da emulsão trazem como principais vantagens a maior facilidade de espalhamento, a possível potenciação da penetração, absorção e conseqüente atividade dos componentes em função da ação emoliente de seus constituintes, a possibilidade de separação de compostos 
incompatíveis, de mistura de elementos não miscíveis e proteção a compostos quimicamente instáveis (SILVA \& SOARES, 1996).

\subsubsection{Matérias-primas empregadas no desenvolvimento das emulsões}

De modo geral, as matérias-primas das emulsões devem apresentar segurança toxicológica, ausência de compostos alergênicos, sensibilizantes e irritantes. Os excipientes utilizados na preparação das emulsões cosméticas são: emolientes, emulsionantes (tensoativos), umectantes, espessantes, conservantes, antioxidantes e sequestrantes (ANSEL, POPOVICH \& ALLEN, 2000).

a) Umectantes: são substâncias higroscópicas com propriedade de absorção de vapor de água do ambiente, caracterizadas pela ação de hidratação. São utilizadas em emulsões $\mathrm{O} / \mathrm{A}$, a fim de proteger a formulação da perda de água e de seu endurecimento (MARTINS, 2003).

b) Tensoativos não iônicos hidrófilos: São compatíveis com tensoativos aniônicos e por serem hidrófilos são solúveis em água (MARTINS, 2003).

c) Quelantes: são substâncias que complexam íons metálicos inativando-os e impedindo sua ação danosa sobre os componentes da formulação. Eles podem estabilizar polímeros doadores de viscosidade e mantêm a transparência de sistemas que podem turvar com a presença de metais (MARTINS, 2003).

d) Conservantes: são substâncias que evitam a proliferação microbiana em produtos e conferem: estabilidade ao produto; segurança ao consumidor, são efetivos contra formas vegetativas de bactérias e agem na estrutura da célula (MARTINS, 2003).

e) Emolientes: são substâncias oleaginosas, insolúveis em água que são aplicadas sobre a pele para promover maciez e suavidade. Atuam como uma barreira física, protegendo a pele dos irritantes hidrossolúveis, bactérias presentes em partículas de poeira e efeitos 
danosos do ar. Os emolientes de origem vegetal são os que apresentam menor comedogenicidade (MARTINS, 2003).

f. Antioxidantes: barram ou retardam a oxidação dos componentes das formulações tais como: fragrâncias, corantes, ativos, ceras e óleos vegetais. São divididos em clássicos e não clássicos. Os clássicos sofrem redução para evitar a oxidação do componente orgânico. Os não clássicos captam os radicais livres provenientes da oxidação (MARTINS, 2003).

g. Espessantes Orgânicos de Fase Oleosa e Co-emulsionantes: conferem maior opacidade ao creme e aumentam a viscosidade da formulação (MARTINS, 2003).

h. Tensoativos não iônicos para componentes oleosos: não apresentam carga, não são ionizados em água. São compatíveis com tensoativos aniônicos e emulsionam componentes oleosos (MARTINS, 2003).

\subsubsection{Aplicação Cosmética de Emulsões com Cristais Líquidos}

Os cristais líquidos são caracterizados por possuírem a ordem estrutural das moléculas fortemente reduzida, mas mantendo a presença de algum grau de ordem orientacional, possuindo capacidade de movimentação rotacional e translacional, característicos de líquidos e mantendo orientação e interação entre as moléculas, características de sólidos cristalinos. As moléculas das substâncias que se organizam no estado líquido-cristalinos são, geralmente, levemente alongadas e seus eixos são paralelos uns aos outros (SANTOS, 2006).

Em emulsões cosméticas, o tipo mais comum de cristal líquido encontrado é o liotrópico, com arranjo estrutural designado como lamelar. Essas fases lamelares são 
responsáveis pela estabilização das emulsões devido ao aumento da viscosidade como, por exemplo, quando álcoois graxos são adicionados (SANTOS, 2006).

Os cristais líquidos possuem quatro aplicações principais em produtos cosméticos. A primeira deve-se ao fato de que cristais líquidos estabilizam a emulsão contra a coalescência, mas não contra a floculação, sendo assim utilizados como promotores de estabilidade; a segunda envolve a solubilização de substâncias pouco solúveis em alguns solventes; a terceira está relacionada com a emulsificação espontânea e, finalmente, a quarta aplicação, é um sistema de liberação controlada de ativos, atuando como barreira contra a difusão do ativo por meio do sistema (SANTOS, 2006).

\subsection{Antioxidantes}

Antioxidantes são definidos como substâncias que, quando presentes em baixas concentrações comparadas com as de um susbtrato oxidável, diminuem ou previnem significativamente a oxidação desse susbtrato (HALLIWELL \& GUTTERIDGE ,1999).

Os antioxidantes interrompem a cadeia de radicais livres. Existem duas propriedades que são eficientes em um antioxidante. A primeira é que o antioxidante deve reagir rapidamente com o radical livre, gerando um novo radical. A segunda propriedade é a que as novas espécies de radicais devem ser tão não-reativas que não vão atrair outras moléculas ao redor (THOMAS, 2000).

As espécies oxidantes (ROS/RNS) geralmente se relacionam à estimulação da expressão de proteínas envolvidas no controle de importantes processos fisiológicos (ciclo celular, resposta imune e neuroregulação). As espécies antioxidantes modulariam negativamente tais funções. $\mathrm{O}$ desequilíbrio entre as modulações positiva e negativa levaria ao aparecimento de doenças. Os antioxidantes (ANTIOX) endógenos incluem enzimas: superóxido dismutase (SOD), catalase (CAT), glutationa peroxidase 
(GSHPX), peroxirredoxinas (PRX) e tiorredoxinas (Trx); compostos de baixo peso molecular: ácido úrico (AU); ácido lipóico $(\mathrm{AL})$; coenzima $\mathrm{Q}(\mathrm{CoQ})$ e glutationa (GSH); tiol proteínas, como albumina, peroxirredoxinas e tiorredoxinas, e proteínas armazenadoras/ transportadoras de íons de metais de transição. As defesas antioxidantes exógenas referem-se aos antioxidantes obtidos por meio da alimentação, sendo os mais estudados o ácido ascórbico (Asc), $\alpha$-tocoferol $(\alpha-\mathrm{TH})$, carotenóides (CAR) e polifenóis (CERQUEIRA, MEDEIROS \& AUGUSTO, 2007). A Figura 14 aborda um esquema demonstrativo de regulação fisiológica modulada pelo estado redox intracelular.

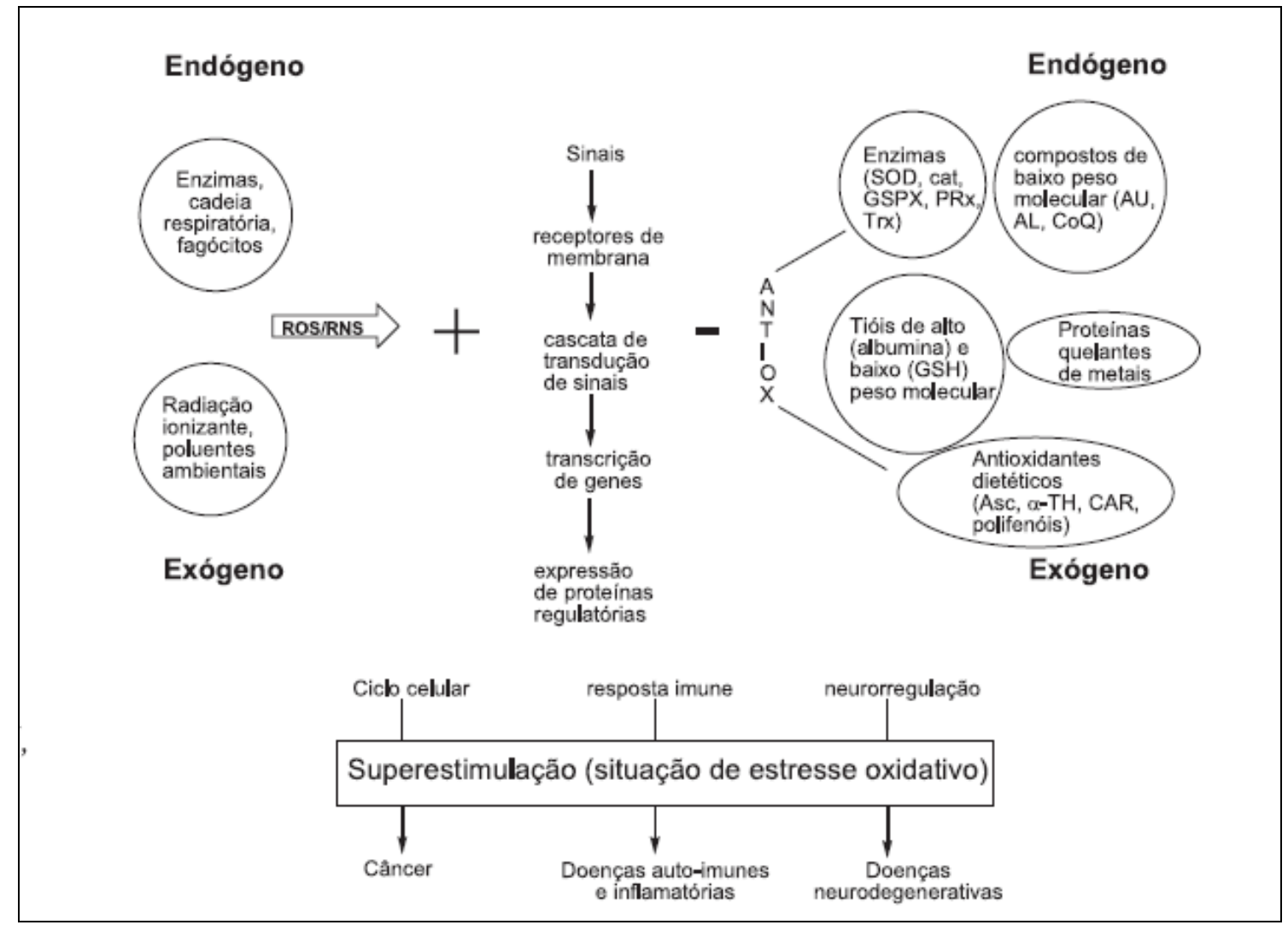

Figura 14. Esquema demonstrativo de regulação fisiológica modulada pelo estado redox intracelular (CERQUEIRA, MEDEIROS \& AUGUSTO, 2007). 
Os principais mecanismos de ação de compostos antioxidantes incluem captadores de radicais e supressores de estados excitados; sistemas catalíticos que neutralizam ou eliminam ROS/RNS e a ligação de íons metálicos a proteínas, o que os torna indisponíveis para a produção de espécies oxidantes. Entre os principais antioxidantes encontrados no plasma humano estão proteínas/peptídeos com grupamento tiol $(\mathrm{SH})(800-1000 \mu \mathrm{mol} / \mathrm{L})$, sendo a albumina a principal representante; ácido úrico $(150-400 \mu \mathrm{mol} / \mathrm{L})$; ácido ascórbico $(30-150 \mu \mathrm{mol} / \mathrm{L})$; tocoferol $(20-50$ $\mu \mathrm{mol} / \mathrm{L})$ e carotenóides $(0,08-3 \mu \mathrm{mol} / \mathrm{L})$ (CERQUEIRA, MEDEIROS \& AUGUSTO, 2007).

\subsubsection{Características de um bom antioxidante}

Um antioxidante lipossolúvel efetivo deve apresentar taxa constante para combater radicais livres muito maior que a vitamina E; o radical livre intermediário deve ser rapidamente reduzido ou como a vitamina E, deve pausar a oxidação e por último, uma concentração efetiva do antioxidante deverá apresentar o estresse do radical local. No plasma, antioxidantes hidrossolúveis devem combater radicais como superóxido pelo menos tão rápido como ascorbato ou apresentar uma concentração no plasma igual ou maior que o ascorbato (THOMAS, 2000).

Durante o estresse oxidativo causado pela exposição prolongada a radiação UV, os antioxidantes naturais da pele são severamente reduzidos, resultando em uma proteção insuficiente e danos celulares. Os danos oxidativos podem desencadear fotoenvelhecimento e câncer de pele (ROPKE et al, 2003).

Existem pelo menos três caminhos que afetam a concentração antioxidante pela radiação UV, entre eles destacam-se: absorbância da luz; reação com oxigênio reativo 
gerada pela interação entre fotossensibilizador e luz UV e mecanismo de reciclagem de antioxidante, no qual um antioxidante pode poupar a expansão do outro (ROPKE et al, 2003).

Os antioxidantes de baixo peso molecular, não sintetizados pelo corpo humano, são o ácido ascórbico (vitamina C) e o tocoferol (vitamina E), considerado o antioxidante lipofílico de maior importância. Além desses, estão presentes compostos antioxidantes sintetizados pelo organismo, como a ubiquinona, glutationa, tioredoxina e

o ácido lipóico. As principais enzimas antioxidantes identificadas na pele são o superóxido dismutase (SOD), a catalase, a glutationa redutase e a glutationa peroxidase. Também estão presentes na pele enzimas auxiliares, responsáveis pelo suprimento de coenzimas como NADPH/NADH (nicotinamida adenina dinucleótido fosfato/ nicotinamida adenina dinucleotídeo), NADPH ubiquinona redutase e o sistema tioredoxina/ tioredoxina redutase, que exerce importante função antioxidante (ROPKE, 2003).

\section{4. Ácido Ascórbico}

A estrutura química do ácido ascórbico (AA) (Figura 15) foi primeiramente identificada em 1933 por Svirbely e Szent-Gyort, que demonstraram que a pimenta continha grande quantidade de vitamina $\mathrm{C}$, facilmente isolável o que permitiu o estudo da sua estrutura por numerosos químicos europeus. Simultaneamente, Haworth \& Hirst sintetizaram a vitamina C e estabeleceram sua fórmula estrutural. Em 1953, Isherwood et al realizaram síntese do AA (Figura 16) a partir de plantas e animais (SVIRBELY \& SZENT GYORGYI, 1933; ISHERWOOD, CHEN \& MAPSON, 1954; GONÇALVES, 2001). 

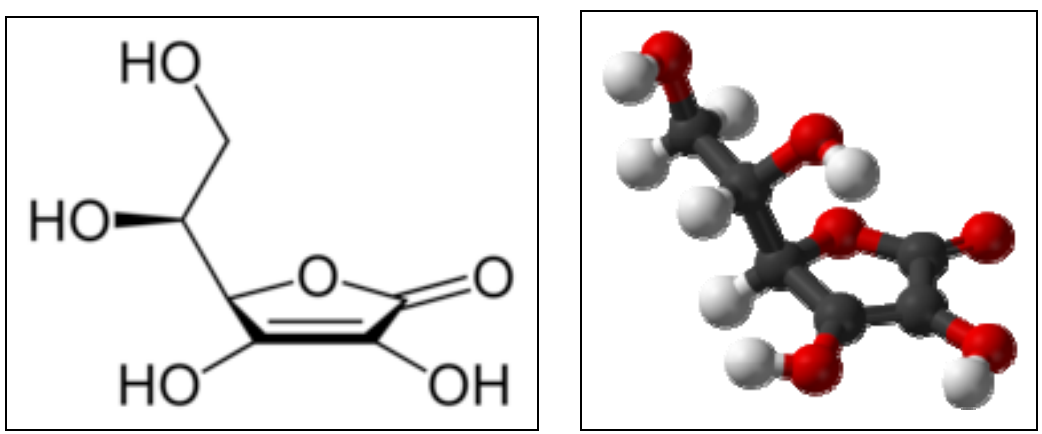

Figura 15. Estrutura química do ácido ascórbico na formas plana e tridimensional (ISHERWOOD, CHEN \& MAPSON, 1954).

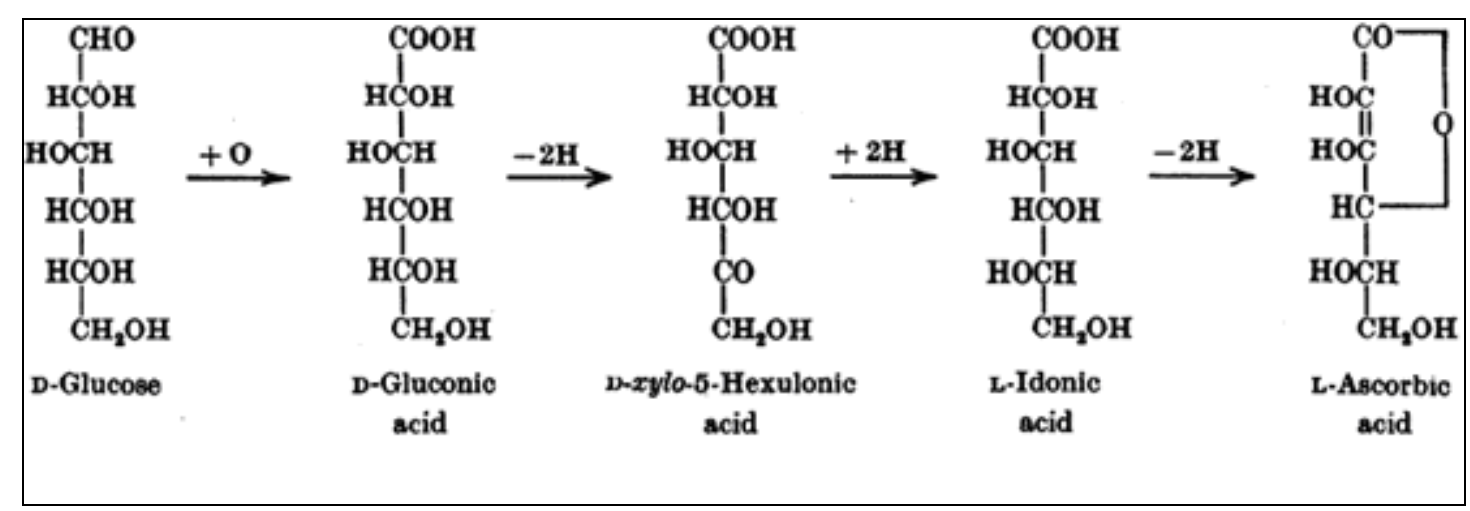

Figura 16. Esquema da síntese do AA a partir da D-Glucose (ISHERWOOD, CHEN \& MAPSON, 1954).

$\mathrm{O}$ ácido $L$-ascórbico $\left(\mathrm{H}_{2} \mathrm{~A}\right)$ possui a estrutura de um diol que é oxidado formando o ácido $L$-deidroascórbico (Figura 17). Nos equilíbrios ácidos, os ânions (HA ${ }^{-}$ e $\mathrm{A}^{2-}$ ) são estabilizados pela distribuição da carga por meio do sistema enona $\mathrm{O} 1=\mathrm{C} 1$ $\mathrm{C} 2=\mathrm{C} 3-\mathrm{O} 3$, sendo o hidrogênio mais ácido o do grupo hidroxil ligado ao $\mathrm{C} 3^{1-3}$ (Figura 18) (FORNARO \& COICHEV, 1997). 


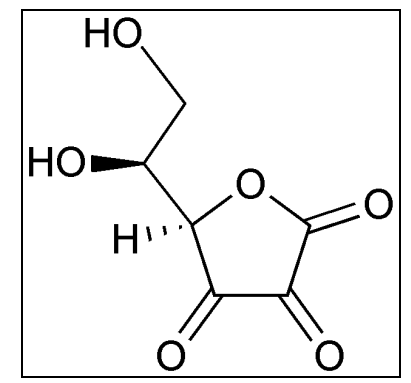

Figura 17. Estrutura química do ácido L-deidroascórbico (FORNARO \& COICHEV, 1997).

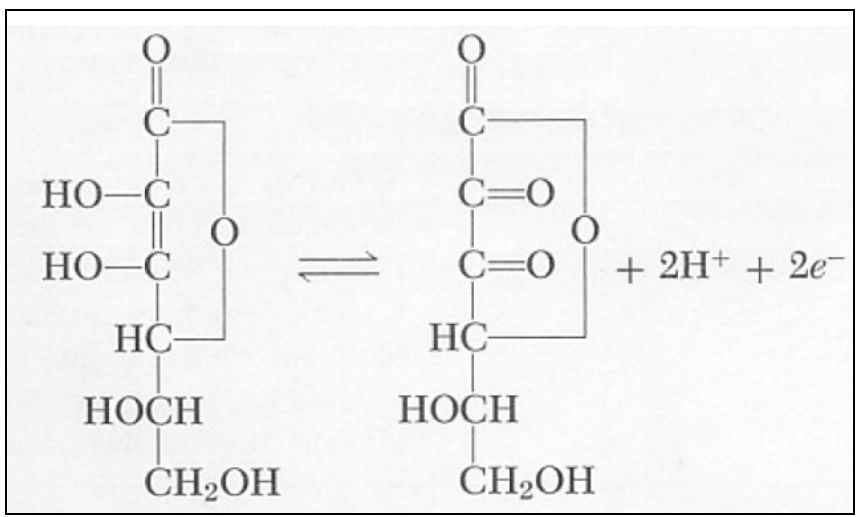

Figura 18. Oxidação do ácido ascórbico a $L$-deidroascórbico (FORNARO \& COICHEV, 1997).

Para a oxidação do AA, no total dois prótons e dois elétrons são perdidos. Em meio aquoso é importante considerar que o ácido $L$-deidroascórbico predomina (99\%) na forma da espécie bicíclica hidratada (bc) $\mathrm{A}_{\mathrm{ox}}$ (Figura 19). A reação de decomposição (Figura 20) do ácido deidroascórbico ocorre com base na abertura do anel por hidrólise com a formação do ácido 2,3-diceto- $L$-gulônico, que é considerada irreversível. Sendo assim, a vitamina $\mathrm{C}$ na forma de AA é instável, oxidando-se muito facilmente (GONÇALVES, 2001; FORNARO \& COICHEV, 1998). É válido relatar que, a presença de água e outros fatores como luz, elevadas temperaturas, alto $\mathrm{pH}$ e oxigênio 
dissolvido no meio aceleram a degradação do ácido ascórbico em formulações cosméticas aquosas (RIBEIRO, 2006).

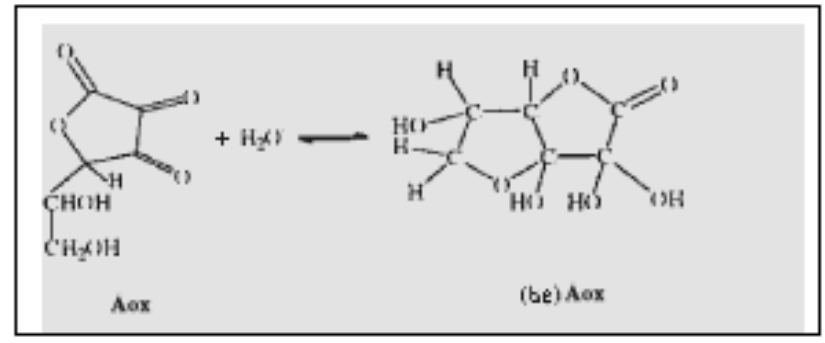

Figura 19. Ácido $L$-deidroascórbico na forma da espécie bicíclica hidratada (FORNARO \& COICHEV, 1997).

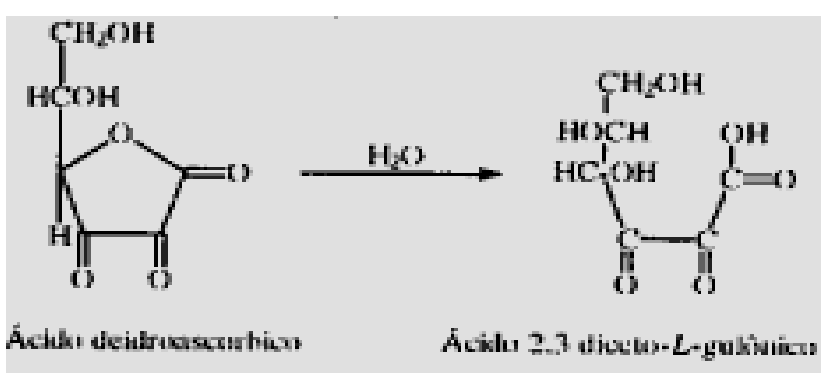

Figura 20. Reação de decomposição do ácido deidroascórbico (FORNARO \& COICHEV, 1997).

Em relação às propriedades físico-químicas do AA, ele apresenta-se como uma substância branca, sólida cristalina (Figura 21), inodora, de fórmula empírica $\mathrm{C}_{6} \mathrm{H}_{8} \mathrm{O}_{6}$, peso molecular $176,13 \mathrm{~g} / \mathrm{mol}$; densidade $1,65 \mathrm{~g} / \mathrm{cm}^{3}$; ponto de fusão $190-192$ ${ }^{\circ} \mathrm{C}$; e pKa de ionização 4,2. Em relação à solubilidade, é muito solúvel em água, pouco solúvel em álcool e insolúvel em solventes orgânicos (FORNARO \& COICHEV, 1997; GONÇALVES, 2001). 


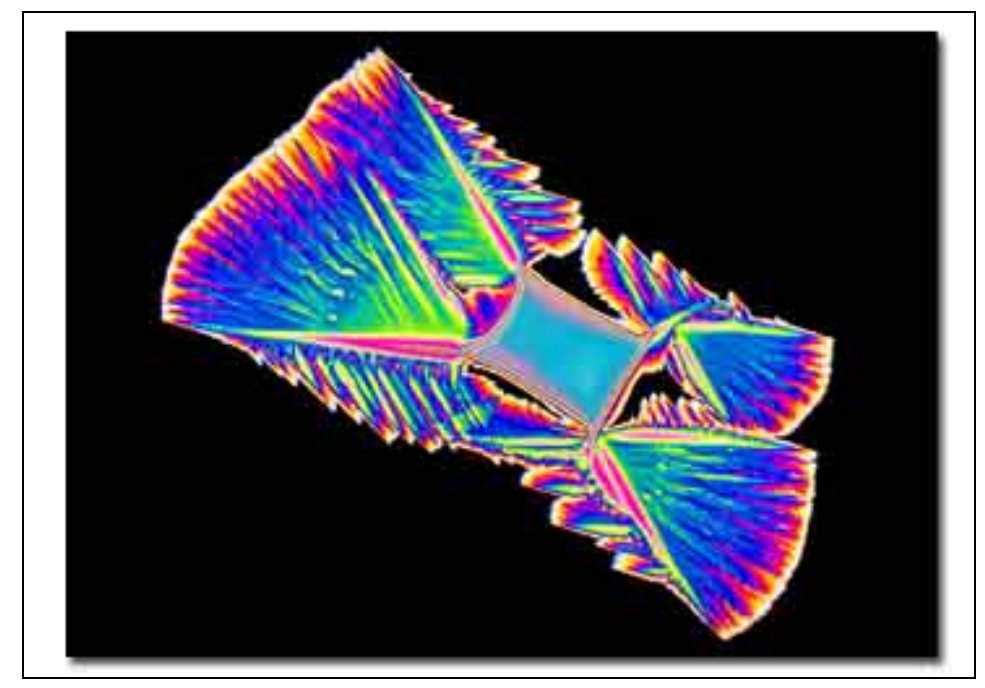

Figura 21. Cristais do ácido ascórbico vistos com luz polarizada (FORNARO \& COICHEV, 1997).

O AA, apesar de ser hidrofílico, é capaz de permear a pele após a aplicação. Para que apresente bom desempenho em formulações cosméticas, deve ser usada a forma levógira não ionizada, que é capaz de atravessar a camada córnea mais facilmente (RIBEIRO, 2006).

SILVA e colaboradores abordaram a importância do processo de desenvolvimento de um veículo para a performance final de um produto contendo ácido ascórbico e avaliaram a influência do $\mathrm{pH}$ da formulação na absorção cutânea desse ativo. Os autores salientam a importância de se definir o veículo, viscosidade e a absorção percutânea requerida. No experimento realizado eles utilizaram um gel não iônico com pH 2,8; 4,5 ou 5,3 contendo 2\% de ácido ascórbico. Os resultado obtidos demonstraram que as formulações com $\mathrm{pH}$ 4,5 e 2,8 mostraram maiores níveis de absorção que a formulação com pH 5,3. No entanto, eles recomendam o pH de 4,5 para produtos de cuidado com a pele contendo ácido ascórbico como ativo principal, pois é compatível com a pele e favorável ao seu metabolismo normal ( SILVA \& MAIA CAMPOS, 2000). 
O AA desempenha importantes efeitos fisiológicos na pele, tais como proteger os tecidos e as células contra danos oxidativos provocados por radicais livres e espécies reativas (CHANG \& CHANG, 2005; GALLARATE, CARLOTTI \& TROTTA, 1999; SPICLIN, GASPERLIN \& KMETEC, 2001).

Dentre as principais ações do AA estão: neutralizar ânions superóxido $\left(\mathrm{O}_{2}\right)$ e oxigênios reativos. Funciona também como um antioxidante de quebra de cadeia, pois após a transferência de um único elétron, o radical livre ascorbato tem potencial próoxidante relativamente baixo. O AA destaca-se por participar como co-fator na hidroxilação da hidroxiprolina, importante aminoácido do tecido conjuntivo e das fibras colágenas, assim, ele contribuí de forma significativa para a formação de novas fibras colágenas, melhorando a elasticidade e firmeza cutânea (MAIA CAMPOS et al, 2000; GALLARATE et al, 1999).

O AA reduz ROS/RNS em leucócitos ativados, pulmão e mucosa gástrica. No trato respiratório pode reagir rapidamente com poluentes do ar, como $\mathrm{O}_{3}$, fumaça de cigarro e $\mathrm{NO}_{2}$. Além de eliminar diretamente ROS/RNS, o AA regenera o $\alpha$-tocoferol (Figura 22) e, portanto, participa do mecanismo protetor contra lipoperoxidação (HALLIWELL \& GUTTERIDGE, 1999). As etapas da lipoperoxidação do $\alpha$-tocoferol são (Figura 23), (A) Iniciação: o grupo metileno de ácidos graxos poliinsaturados é atacado por radicais livres, havendo o rearranjo das duplas ligações na forma de dieno conjugado. Simultaneamente há formação de um radical alquila $(\mathrm{R} \bullet)$ no carbono central. $\mathrm{O}$ radical alquila reage com $\mathrm{O}_{2}$ formando alquilperoxila (ROO•). Propagação: $\mathrm{ROO} \bullet$ ataca outras moléculas de lipídios (não mostrado). Terminação: as reações em cadeia são interrompidas por interação entre os próprios radicais (não mostrado), ou (B) entre radicais e $\alpha$-tocoferol, originando produtos não-radicalares e o radical tocoferila. $\mathrm{O}$ 
radical $\alpha$-tocoferila é reduzido por ação do ácido ascórbico. Uma vez que a vitamina $\mathrm{C}$ é depletada, outros compostos antioxidantes (ácido úrico e proteínas contendo tiol) podem reduzir o radical $\alpha$-tocoferila, mas de forma menos eficiente (CERQUEIRA, MEDEIROS \& AUGUSTO, 2007). Estudos realizados por LOPEZ-TORRES, THIELE, SHINDO, 1998 comprovaram que a aplicação tópica de $\alpha$-tocoferol $(5 \%)$ associado à ascorbato (5\%) na pele de camundongos sem pêlo, antes da irradiação crônica com radiação UVB e UVA, foi eficaz na prevenção do fotoenvelhecimento. A aplicação tópica de palmitato de ascorbila e de acetato de $\alpha$-tocoferol (pró fármacos mais estáveis do ponto de vista farmacotécnico) foi menos eficiente na prevenção do fotoenvelhecimento que as formas livres (ROPKE, 2003).

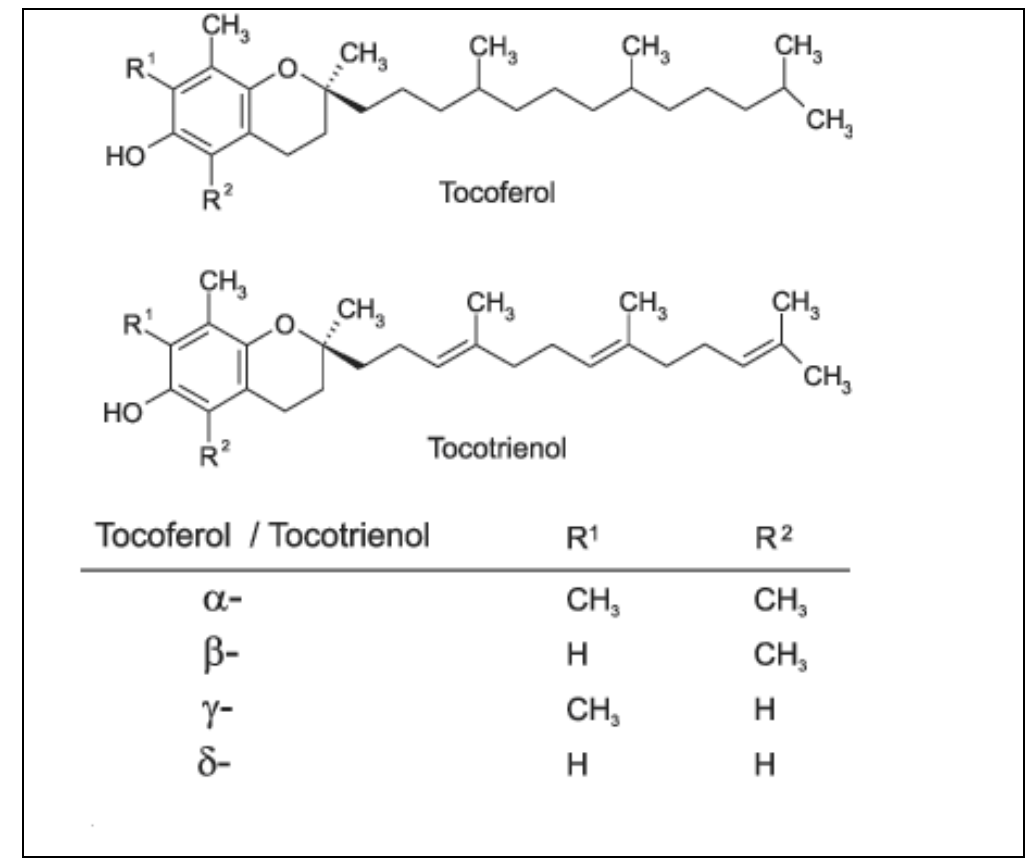

Figura 22. Estrutura química do tocoferol e tocotrienol. 


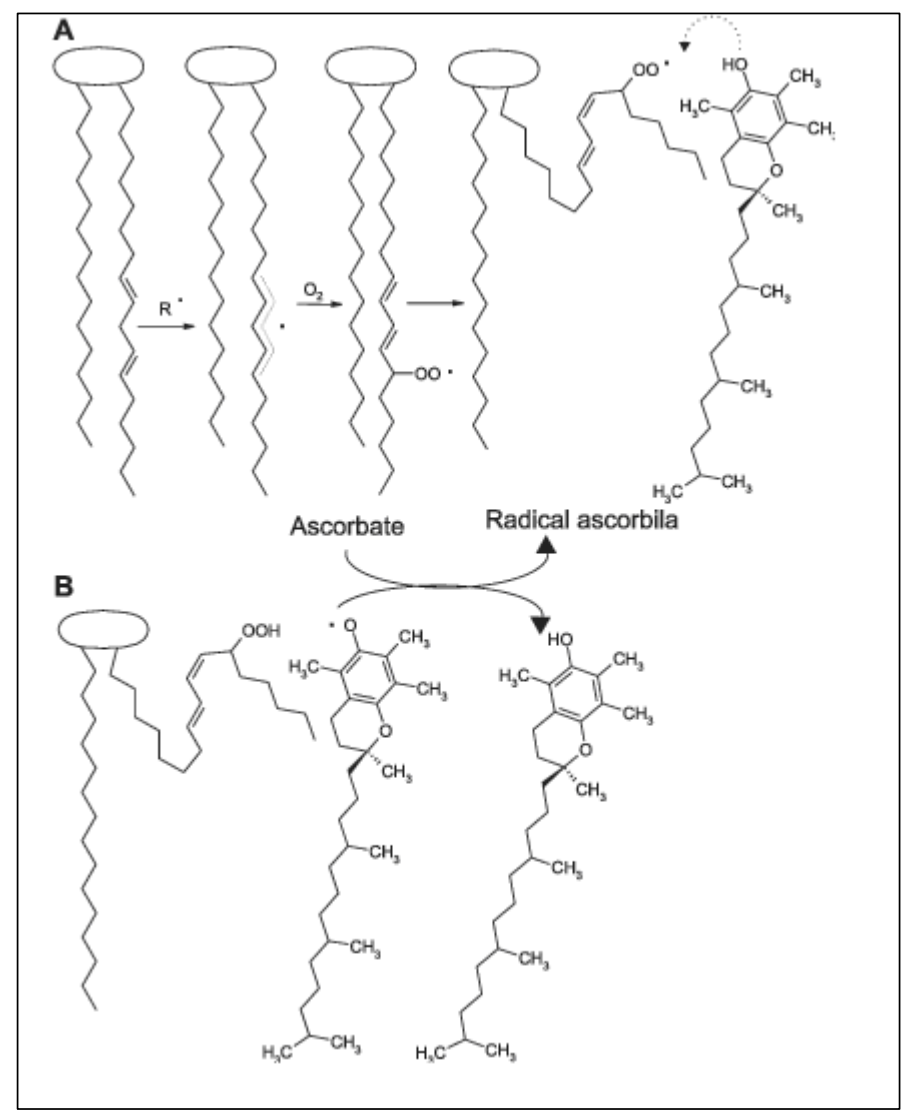

Figura 23. Etapas da lipoperoxidação e ação antioxidante do $\alpha$-tocoferol.

Para formular cosméticos de forma segura com AA é importante um controle rígido de $\mathrm{pH}$, o uso adequado de agentes conservantes para prevenir e controlar a degradação do AA. O oxigênio deve ser estritamente proibido nesse tipo de formulação. Essas formulações devem será condicionadas em embalagens livre da exposição do oxigênio e da luz (THORMAHLEN, 2000).

Pelo fato do AA apresentar-se como um princípio ativo instável, foram sintetizados derivados desse princípio ativo. Esses derivados buscam manter a bioatividade do AA, no entanto apresentam maior estabilidade (SILVA \& MAIA CAMPOS, 2000). 


\subsubsection{Derivados do ácido ascórbico}

Devido a baixa estabilidade do AA em formulações cosméticas foram desenvolvidos os derivados do AA. Dentre os derivados do AA disponíveis no mercado, destacam-se: fosfato ascorbil magnésio $\left(\mathrm{VC}-\mathrm{PMG}^{\circledR}\right)$; tetraisopalmitato de ascorbila $\left(\mathrm{VC}^{-} \mathrm{P}^{\circledR}\right)$; palmitato de ascorbila; talasferas com vitamina C; nanosferas de vitamina C; ácido ascórbico 2-glicosado(AA2G) e o AMS (Ascorbosilane $C^{\circledR}$ ) (RIBEIRO, 2006).

O fosfato ascorbil magnésio (Figura 24) é um complexo da vitamina C hidrossolúvel, com alta estabilidade a oxidação. Quando o fosfato ascorbil magnésio que é um bioativo, entra em contato com a pele, a enzima fosfatase que está presente nos tecidos é ativada e a vitamina $\mathrm{C}$ intacta é liberada. Em relação à molécula a introdução do grupo fosfórico na segunda posição protege a molécula de uma ruptura ou separação do sistema enediol, conferindo ao fosfato ascorbil magnésio uma maior estabilidade (SEMENZATO et al,1995; TAGAWA \& TABATA, 1988).

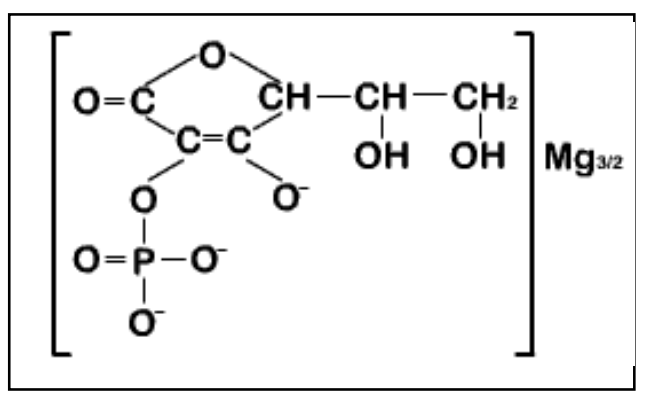

Figura 24. Estrutura química do fosfato ascorbil magnésio (TAGAWA et al, 1988).

O tetraisopalmitato de ascorbila (Figura 25) é um derivado lipossolúvel do AA e ao ser absorvido pela pele vai sofrer ação enzimática sendo clivado e originando o ácido ascórbico livre, que pode então agir como co-fator no sistema enzimático responsável pela síntese do colágeno. Em relação à estabilidade, o tetraisopalmitato de ascorbila é 
considerado um ativo extremamente estável e o $\mathrm{pH}$ deve estar entre 4 e 6 . Por ser estável, o fabricante extingue a necessidade do uso de sistema antioxidante, no entanto quando da necessidade de se aperfeiçoar sua estabilidade o acréscimo de 0,1\% de vitamina E como antioxidante e de $0,2 \%$ de agente quelante são suficientes (NIKKOL, 2002).

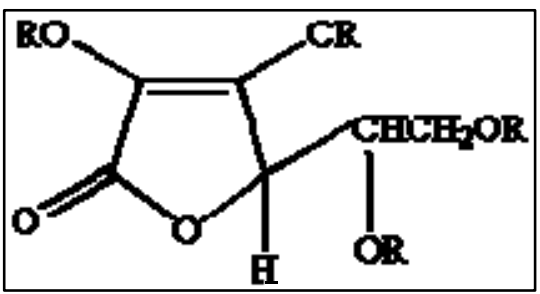

Figura 25. Estrutura química do tetraisopalmitato de ascorbila (NIKKOL, 2002).

O palmitato de ascorbila (Figura 26) é um éster lipofílico com pH neutro, que não irrita a pele e apresenta boa eficácia em formulações tópicas ( LEONARDI, 2004).

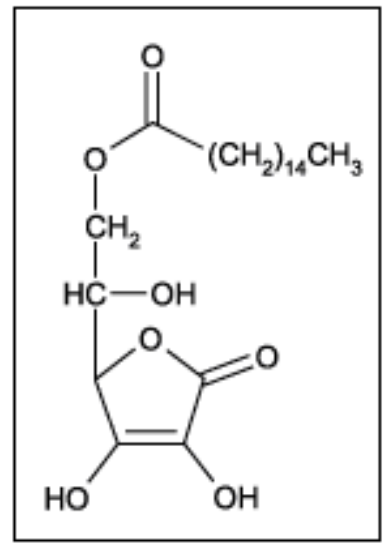

Figura 26. Estrutura química do palmitato de ascorbila (AXOORA PLATFORM, 2007).

As talasferas com vitamina $\mathrm{C}$, ou com seus derivados, têm dimensões microscópicas, que se rompem na derme, de forma gradual, para promover um efeito prolongado, ou seja, promovem a liberação prolongada da vitamina na pele. Uma vez 
que as talasferas veiculam a substância ativa é importante conhecer a relação da concentração de ativo, no caso de vitamina $\mathrm{C}$ (ou um de seus derivados), nas talasferas (LEONARDI, 2004).

As nanosferas de vitamina $\mathrm{C}$ são cápsulas estáveis, sendo liberadas de acordo com uma cronologia definida. Esta liberação ocorre em nível cutâneo, assegurando uma melhor biodisponibilidade, evitando sobrecargas desnecessárias. A dispersão da vitamina $\mathrm{C}$ na pele se torna homogênea e harmoniosa, conferindo maior eficácia, estabilidade e segurança aos produtos cosméticos (EXSYMOL, 2005; LEONARDI, 2004).

O derivado ácido ascórbico (Figura 27) 2-glicosado (AAG2), pode ser trabalhado em formulações com pHs levemente ácido a neutro e, na pele, sofre ação da glucosidase, que libera o ácido ascórbico gradativamente. O AA2G (ácido ascórbico 2glucosado) é a primeira vitamina C pura estabilizada com glucose (HAYASHIBARA et $a l)$.

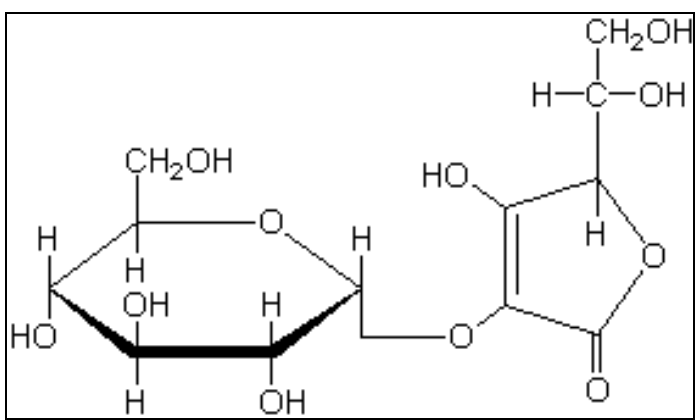

Figura 27. Estrutura química do AA2G (WAKO-CHEM, 2004). 


\subsubsection{Ascorbato de monometilsilanotriol}

O AMS é um derivado do ácido ascórbico formado por uma mistura de sílicio orgânico e ácido ascórbico (LEONARDI, 2004).

O AMS apresenta um radical $\mathrm{R}$ nas extremidades da molécula, esse $\mathrm{R}$ é lábil, pois o R é variável e pode ser tanto uma molécula de pectina ou ácido ascórbico, pois a função do R na molécula é estabilizar a molécula para impedir que haja continuidade da reação com o tri-hidróximetil silício. Essa molécula de tri-hidróximetil silício, reage entre si e essa reação pode desencadear a formação de um polímero que não apresenta bioatividade e assim a molécula não poderia ser absorvida na pele. Sendo assim, o AMS (Figura 28) apresenta peso molecular instável (EXSYMOL, 1998).

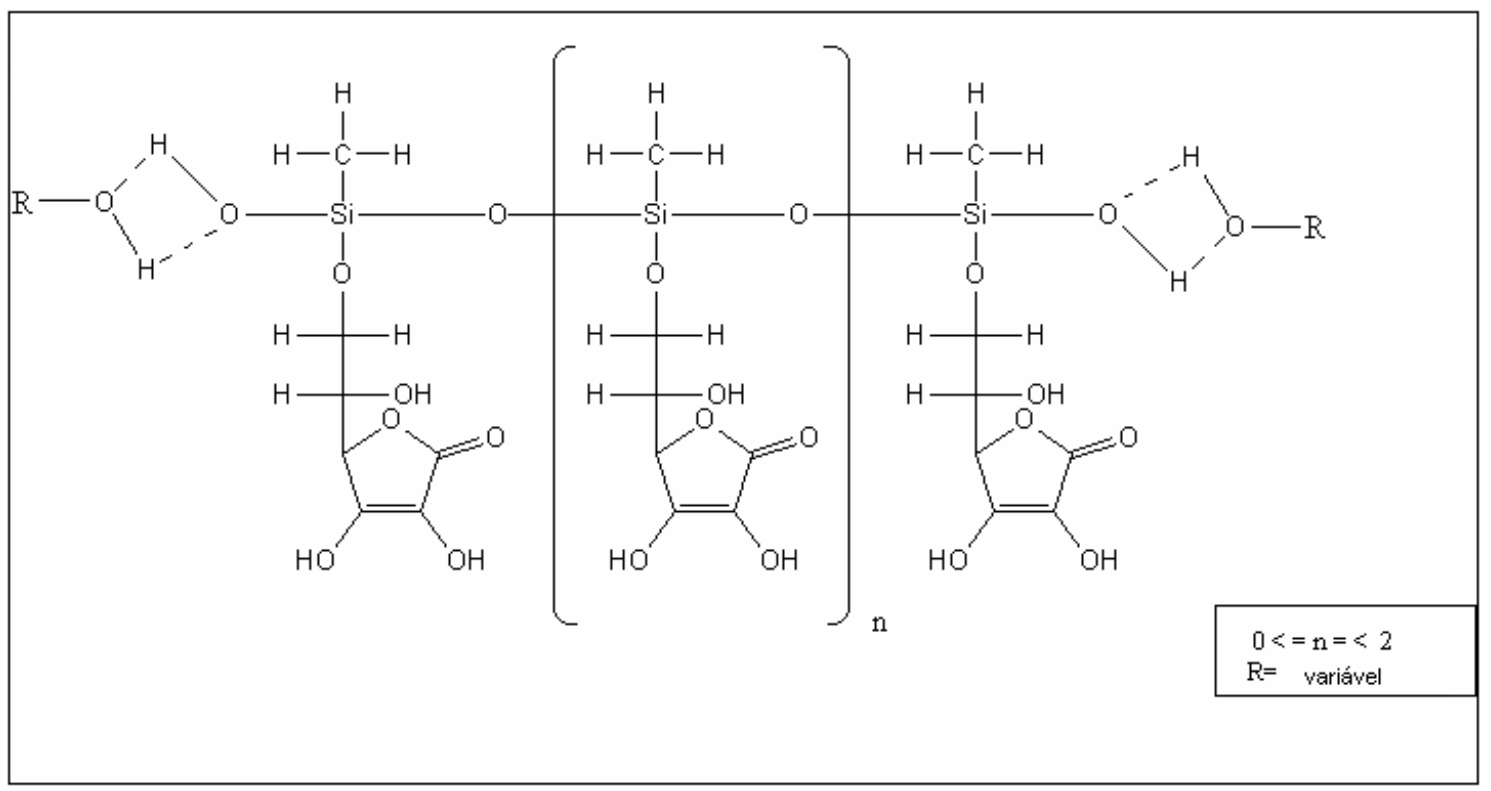

Figura 28. Estrutura química do AMS (EXSYMOL, 1998).

O AMS apresenta INCI name: Ascorbyl Methylsilanol Pectinate e CAS (Chemical Abstracts Service) number: [135800-41-8 ] (EXSYMOL, 1998). Em relação ao aspecto, o AMS, cujo nome comercial é Ascorbosilane $\mathrm{C}^{\circledR}$ é comercializado na forma de solução aquosa contendo $1 \%$ de AMS. Essa solução apresenta coloração 
levemente amarelada, $\mathrm{pH}$ entre $5-7$ e densidade entre $0,90-1,01 \mathrm{~g} / \mathrm{cm}^{3}(\mathrm{EXSYMOL}$, 1998).

Em relação às atividades cosméticas exercidas; o AMS agrega as propriedades cosméticas do AA à dos silanóis. A aplicação tópica do AMS aumenta a proteção proporcionada pelos mecanismos de defesa da pele, além de participar da biossíntese da hidroxiprolina (precursor do colágeno), proteoglicanas e carnitina. Por ser uma molécula estável e por apresentar tolerância cutânea e possuir atividade biológica acentuada, esse ativo é recomendado para a incorporação em produtos cosméticos, tais como, cremes, emulsões, leites e géis. Além de ser compatível com uma vasta gama de matérias primas e princípios ativos (POLYTECHNO, 2005).

A estrutura química dos silanóis e sua habilidade de espontaneamente unir as ligações de hidrogênio com as hidroxilas das moléculas circundantes, favorece um alto teor de água. Os silanóis são, conseqüentemente, hidratantes "biológicos" que atuam sobre: a normalização do metabolismo celular; o aumento do número de aminoácidos polares na elastina; os quais são indiretamente responsáveis pela hidratação de proteínas e a pectina mantém certa hidratação a nível cutâneo, através da retenção de água (POLYTECHNO, 2005).

Os silanóis possuem uma grande afinidade com a membrana celular, o que irá potencializar o efeito redutor do ácido ascórbico. Eles irão combater a formação de radicais livres, que possuem efeitos citotóxicos sobre as proteínas, proteoglicanas celulares e DNA. O papel do AA sobre a pele envelhecida está relacionado com o controle dos radicais livres por meio do radical ascorbato (POLYTECHNO, 2005). 
Segundo o fornecedor o uso do AMS é recomendado como um agente rehidratante em emulsões ou géis. Não é recomendada a incorporação em loções hidroalcoólicas (POLYTECHNO, 2005).

\subsubsection{Métodos de análise e quantificação do AA e derivados}

MAIA e colaboradores, desenvolveram e validaram um método de HPLC indicativo de estabilidade para determinação de AA em formulações farmacêuticas semi-sólidas e cosméticas na forma de emulsões óleo/água e gel aquoso, contendo glutationa e metabissulfito de sódio como antioxidantes. $\mathrm{O}$ estudo foi validado por linearidade, precisão e exatidão, bem como apresentou baixos limites de detecção e quantificação, apresentando a sensibilidade dessa ferramenta analítica. A fase móvel utilizada foi ácido metafosfórico $0,2 \%$, metanol e acetonitrila $(90: 8: 2, \mathrm{v} / \mathrm{v} / \mathrm{v})$. Devido à alta especificidade do método, esse permitiu determinar AA na presença de vários excipientes e no caso de possíveis produtos de degradação como o ácido oxálico (MAIA et al, 2006).

WANG e WU determinaram o ácido ascórbico e derivados, simultaneamente empregando o método de Cromatografia Eletrocinética Micelar (MECK). O autor cita inúmeras vantagens da técnica incluindo velocidade; resolução e baixo consumo de reagentes (WANG \& WU, 2005).

KAMEYAMA e colaboradores, avaliaram o efeito do fosfato ascorbil magnésio na melanogênese in vitro e in vivo e como resultado observaram que a aplicação tópica do fosfato ascorbil magnésio foi efetiva no clareamento da pele de várias pacientes com distúrbios de pigmentação. Os resultados sugeriram que a inibição da melanogênese foi forte quando a atividade das enzimas melanogênicas foi relativamente alta. $\mathrm{O}$ fosfato 
ascorbil magnésio a concentração de $10 \%$ foi veiculado a um creme para pele e como conclusão do estudo, os autores verificaram que o fosfato ascorbil magnésio direta ou indiretamente é capaz de suprimir a formação da melanina que é catalisada pela tirosinase e embora o fosfato ascorbil magnésio tenha demonstrado menor atividade quando comprado ao AA, apresentou maior estabilidade (KAMEYAMA et al, 2006).

MAIA-CAMPOS \& SILVA e colaboradores, observaram a penetração na pele do AA, fosfato ascorbil magnésio e ascorbato de magnésio PCA em formulações cosméticas e como resultado avaliaram que o ascorbato de magnésio PCA foi mais absorvido que o ácido ascórbico e o fosfato ascorbil magnésio. Verificaram ainda, que o melhor veículo para penetração na pele foi a formulação em gel, seguida da emulsão para AA e gel creme para fosfato ascorbil magnésio. O gel creme apresentou ter ação na hidratação na epiderme de porcos após 15 dias de tratamento cutâneo. Foi comprovado pelo estudo que a adição de AA e seus derivados para essa formulação intensificaram a hidratação intra e extracelular (MAIA-CAMPOS \& SILVA, 2000).

AUSTRIA, SEMENZATO E BETTERO avaliaram a estabilidade do fosfato ascorbil magnésio e do palmitato de ascorbila em formulações tópicas e quantificaram esses ativos por cromatografia líquida de alta eficiência(CLAE) empregando fase reversa, com duas fases móveis para diminuir o tempo de análise para cada molécula. $\mathrm{O}$ eluente empregado para o fosfato ascorbil magnésio foi acetonitrila-tampão fosfato $(0,3$ $\mathrm{M}, \mathrm{pH}$ 4) (40:60, v/v) e para palmitato de ascorbila foi metanol-tampão fosfato $(0,02 \mathrm{M}$, $\mathrm{pH}$ 3,5). Como resultado das análises verificou-se que a diferença definitiva no comportamento entre os dois derivados foi evidente e os autores observaram que a introdução do grupo fosfato na posição 2 protege o sistema enediol da hidrólise da molécula comportando-se melhor que o palmitato de ascorbila que apresenta 
esterificação na posição 6, com cadeia lipofilíca longa. De acordo com os autores, o ascorbato de monometilsilanotriol demonstrou ser mais estável que o palmitato de ascorbila (AUSTRIA, SEMENZATO \& BETTERO, 1996).

SHIH e KUANG realizaram a determinação simultânea do fosfato ascorbil magnésio e ácido kójico em loções e cremes contendo concentrações de 1\% e 1,2\% de ácido kójico e 0,5 e 0,6\% de fosfato ascorbil magnésio. $\mathrm{O}$ estudo foi realizado usando uma coluna de microboro e utilizando o método de cromatografia líquida de alta eficiência por pareamento iônico, empregando eluição isocrática com $0,05 \mathrm{mM}$ (TBA) tetrabutilamônio e $0,05 \mathrm{M}$ de tampão fosfato a $\mathrm{pH} 5 \mathrm{com}$ ácido fosfórico contendo 5\%(v/v) de metanol. A taxa de injeção foi $70 \mu \mathrm{L} / \mathrm{min}$. A sensibilidade, precisão e especificidade do método foram satisfatórias para determinação do fosfato ascorbil magnésio e ácido kójico ( SHIH \& KUANG, 2001).

MAIA-CAMPOS e colaboradores, realizaram um estudo para avaliar a atividade antioxidante resultante da associação entre bioflavonóides e as vitaminas palmitato de retinol; acetato de tocoferol e tetraisopalmitato de ascorbila. Os autores verificaram que a associação de vitaminas e bioflavonóides adicionada a formulações dermocosméticas demonstraram uma atividade biológica relevante em termos de fotoproteção devido à associação de bioflavonóides e a ação das vitaminas por diferentes mecanismos, assim como a antioxidação e absorção da radiação UV que sugere que essa associação seja empregada em formulações cosméticas antiaging e de fotoproteção (MAIA-CAMPOS et al, 2006).

FRUCTUS, MONTET e LAZAR, desenvolveram uma formulação contendo derivados do AA, silício orgânico e um extrato vegetal de proteína de trigo hidrolisada . Segundo os autores, a associação dos ativos estimula a síntese de colágeno na pele e 
auxilia no combate ao envelhecimento cutâneo (FRUCTUS, MONTET \& LAZAR, 2002).

\subsection{Técnicas empregadas na caracterização do AMS}

\subsubsection{Espectrofotometria no ultravioleta (UV)}

A espectrofotometria na região do ultravioleta e visível (UV-VIS) compreende o espectro eletromagnético que vai de 160 a $780 \mathrm{~nm}$. A absorção molecular espectroscópica está baseada na medida da transmitância $T$ ou da absorbância $A$ de uma solução, contida em uma célula transparente, tendo um caminho óptico de b centímetros. A concentração de um analito absorvente c é linearmente relacionada à absorbância, como dado pela equação que representa matematicamente a lei de Beer (IGNÁCIO, 2005):

$A=a \cdot b \cdot c$

Sendo:

$a=$ absortividade

$b=$ caminho óptico

$c=$ concentração

Com a finalidade de obter informação útil do espectro de um composto no ultravioleta, deve-se medir cuidadosamente o comprimento de onda de absorção máxima ( $\lambda$ máx) e a intensidade de absorção. O composto deve ser dissolvido em um solvente apropriado que não absorva luz na região estudada (DAYER, 1969).

Embora tenha grande aplicação na química analítica, por se tratar de um método instrumental de relativa simplicidade e baixo custo, a maior parte dos métodos 
espectrofotométricos UV-VIS refere-se à determinação de amostras contendo um único componente. A análise de sistemas multicomponentes é uma limitação da técnica, que tem sido contornada pelo uso de métodos de separação, em especial os cromatográficos, os quais consomem mais tempo e são mais dispendiosos (IGNACIO, 2005).

Na Tabela 3, estão as faixas de comprimento de onda aproximados que correspondem às diferentes cores. A percepção visual das cores é provocada pela absorção seletiva, por um objeto corado, de certos comprimentos de onda (UFPA, 2007).

Tabela 3. Comprimento de onda aproximado das cores (UFPA, 2005).

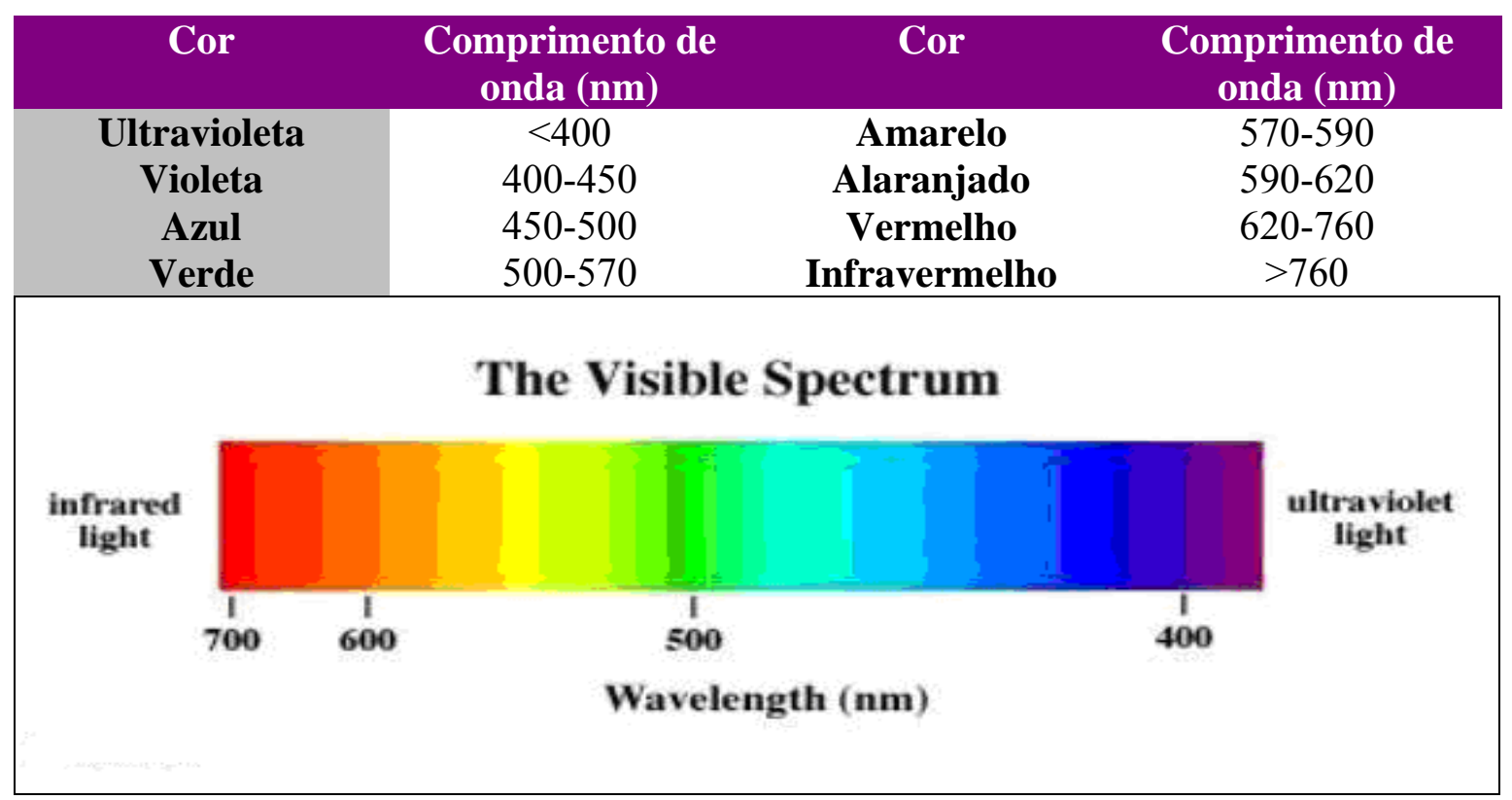




\subsubsection{Espectrofotometria de absorção na região do infravermelho com transformada de Fourier (FTIR).}

A região normal do infravermelho se estende de 2,5 a $15 \mu \mathrm{m}\left(4000\right.$ a $\left.667 \mathrm{~cm}^{-1}\right)$; a região de 0,8 a $2,5 \mu \mathrm{m}\left(12,500\right.$ a $\left.4,000 \mathrm{~cm}^{-1}\right)$; é chamada infravermelho próximo e a região de 15 a $200 \mu \mathrm{m}\left(-667\right.$ a $50 \mathrm{~cm}^{-1}$ )é chamada infravermelho afastado (DAYER, 1969 ).

A condição para que ocorra absorção da radiação infravermelha é que haja variação do momento dipolo elétrico da molécula como conseqüência de seu movimento vibracional ou rotacional (o momento dipolo é determinado pela magnitude da diferença de carga e a distância entre dois centros de carga). Somente nessas circunstâncias, o campo elétrico alternante da radiação incidente interage com a molécula originando espectros. Pode-se dizer que o espectro de absorção no infravermelho tem origem quando a radiação eletromagnética incidente apresenta um componente com freqüência correspondente a uma transição entre dois níveis vibracionais (BARTHUS, 1999).

\subsubsection{Cromatografia em Camada Delgada}

A cromatografia em camada delgada (CCD) convencional é uma técnica simples, flexível de baixo custo utilizada na separação de componentes no controle de medicamentos, e extratos de plantas conforme citado em várias monografias oficiais (UNITED STATES PHARMACOPEIA, 2007).

Na cromatografia em camada delgada (CCD), a fase estacionária é uma camada fina formada por um sólido granulado (sílica, alumina, poliamida, etc.) depositado sobre uma placa de vidro, alumínio ou outro suporte inerte. Pequenas gotas de solução das 
amostras a serem analisadas são aplicadas em um ponto próximo ao extremo inferior da placa. Deixa-se a placa secar e, então se coloca a mesma em um recipiente contendo a fase móvel (solvente ou mistura de solventes). A polaridade do solvente deverá ser de acordo com a substância que se deseja separar. Como somente a base da placa fica submersa, o solvente começa a molhar a fase estacionária e sobe por capilaridade. Deixa-se secar a placa após o deslocamento da fase móvel sobre ela. (PERES, 2002) A cromatografia em camada delgada (CCD) pode ser usada como um método alternativo, de baixo custo na detecção, separação e análise semi-quantitativa (SIMÊNCIO \& YARIWAKE, 2006).

Em relação à avaliação das análises por $\mathrm{CCD}$, sob condições bem estabelecidas, um dado composto percorre sempre uma distância fixa em relação à distância percorrida pelo solvente (ABREU, 2007). Essa relação é chamada valor do Rf e é expressa como

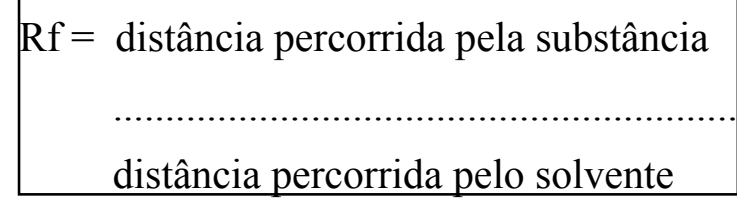

Quando os parâmetros experimentais são especificados, o valor do Rf é uma constante, para um dado composto. E ele pode ser usado para auxiliar a identificação de uma substância. Na Figura 29, pode-se observar a avaliação de uma análise por CCD, sendo "a "distância percorrida pela substância e "b" à distância percorrida pelo solvente (MICRONAL, 2004). 


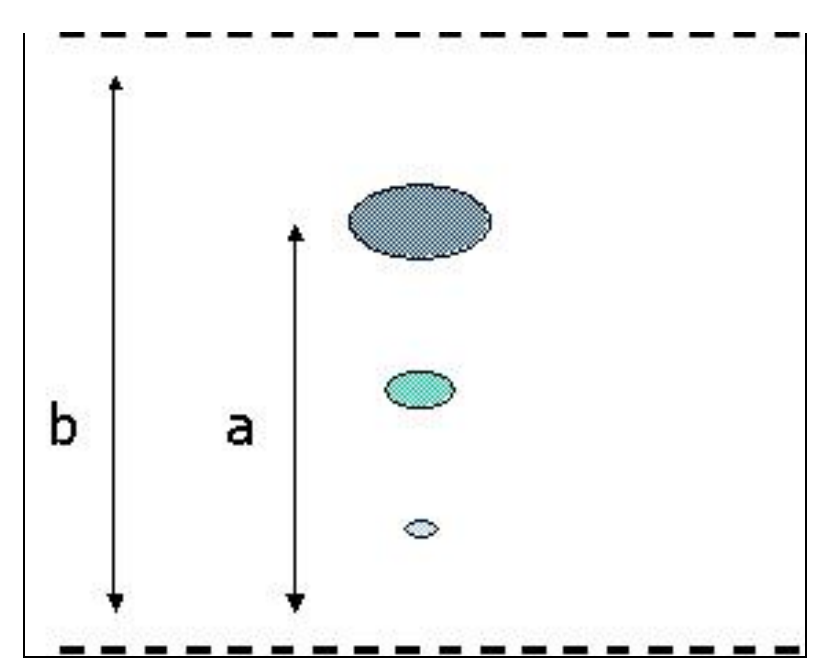

Figura 29. Exemplificação da análise do Rf por CCD (MICRONAL, 2004).

\subsubsection{Perda por Dessecação}

A perda por dessecação é um método gravimétrico que, visa a determinar a quantidade de água e de materiais voláteis através da diferença de peso da amostra após aquecimento até peso constante (UNITED STATES PHARMACOPEIA, 2007).

\subsubsection{Análise Térmica}

O conhecimento das propriedades físico-químicas das matérias-primas é fator indispensável durante o desenvolvimento de medicamentos e cosméticos. O planejamento racional de uma formulação deve ser iniciado com a caracterização do princípio ativo em questão, de modo a otimizar parâmetros de qualidade da forma farmacêutica final (CARDOSO et al, 2005).

A análise térmica é definida como "grupo de técnicas por meio das quais uma propriedade física de uma substância e/ou de seus produtos de reação é medida em função da temperatura, enquanto essa substância é submetida a um programa controlado de 
temperatura (e sob uma atmosfera especifica). Para que uma técnica térmica seja considerada termoanalítica é necessário, segundo a definição, envolver a medição de uma propriedade física, expressa direta ou indiretamente em função da temperatura, e executada sob um programa controlado desta variável (SILVA et al, 2007).

A calorimetria exploratória diferencial (DSC) e a termogravimetria (TG) são as técnicas termoanalíticas mais difundidas e empregadas no desenvolvimento de diferentes estudos sendo aplicadas a uma grande variedade de materiais farmacêuticos (SILVA et al, 2007).

A TG fornece informações com relação às variações de massa em função do tempo e/ou temperatura sob determinadas condições atmosféricas. As análises são executadas por meio de uma termobalança (Figura 30) de elevada sensibilidade, reprodutividade e resposta rápida às variações de massa. Os parâmetros experimentais incluem: razão de aquecimento, atmosfera $\left(\mathrm{N}_{2}\right.$, ar ou outros), vazão de gás, quantidade de amostra, forma cristalina, composição do cadinho e calor de reação envolvido. As curvas obtidas fornecem informações relativas à composição e estabilidade térmica da amostra, dos produtos intermediários e do resíduo formado. A DTG é a derivada primeira da curva TG. Nessa curva os "degraus" correspondentes às variações de massa da curva TG são substituídos por picos que determinam áreas proporcionais às variações de massa, tornando as informações, visualmente, mais accessíveis e com melhor resolução (RODRIGUES et al, 2005; VELASQUEZ et al, 2004). 


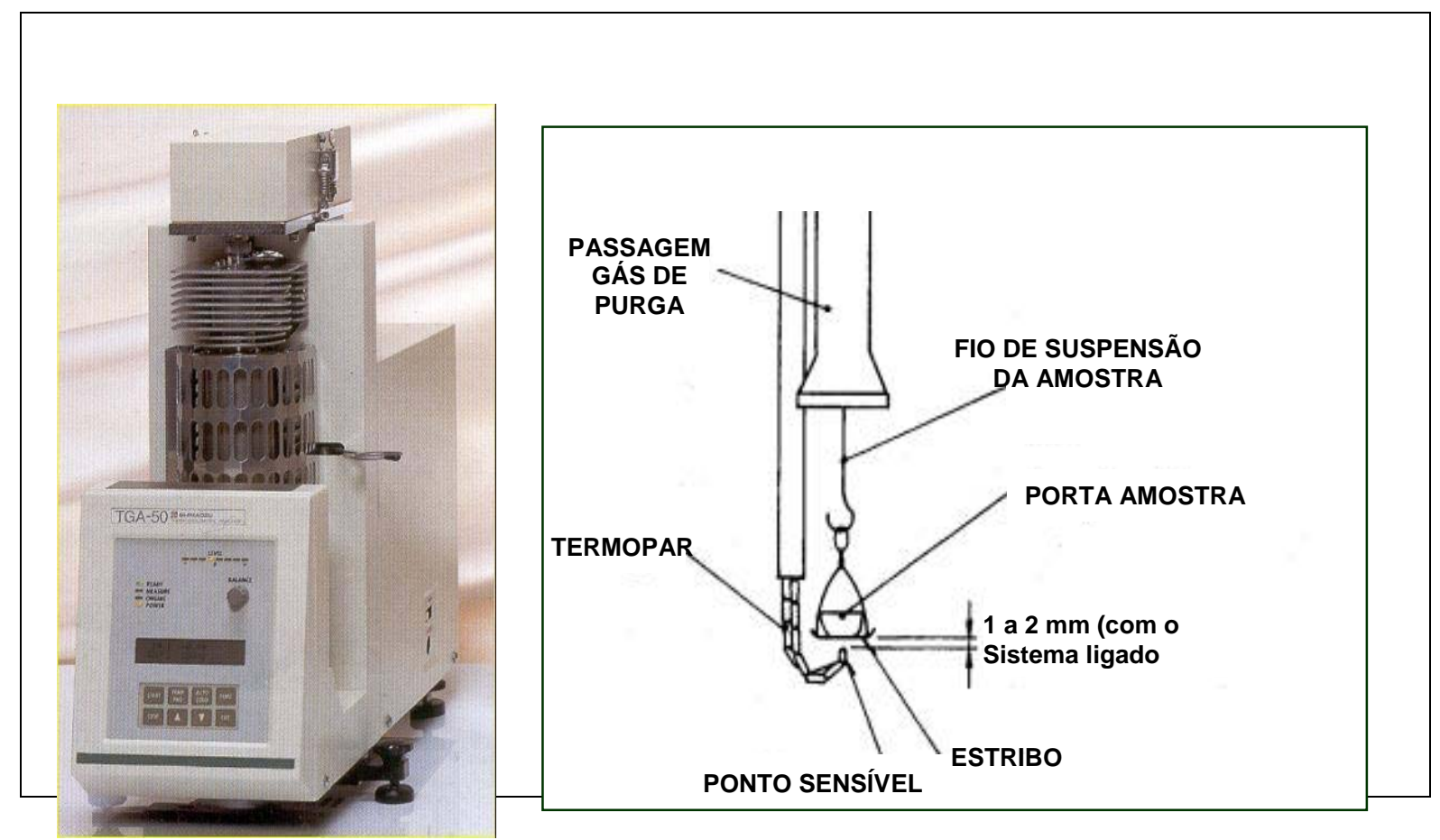

Figura 30. Termobalança TGA 50 (SHIMADZU, 2004).

A DSC é a técnica de análise térmica, na qual se mede a diferença de energia fornecida à substância e a um material de referência, termicamente inerte, em função da temperatura, enquanto a substância e o material de referência são submetidos a uma programação de aquecimento controlado. Existem duas configurações possíveis para aparelhos de DSC, ou seja, DSC com compensação de potência e DSC com fluxo de calor (MATOS \& MACHADO, 2004).

Na primeira configuração a amostra e o material de referência são aquecidos em compartimentos separados em condições isotérmicas submetidos à igual variação de potência de entrada no forno. Neste caso, os eventos são apresentados na forma de picos, os ascendentes correspondem a processos endotérmicos e os descendentes, os exotérmicos (MATOS \& MACHADO, 2004).

No caso da DSC com fluxo de calor (Figura 31), a amostra e o material de referencia são colocados em cápsulas idênticas, localizadas sobre o disco termoelétrico, 
liga metálica de cobre e níquel, aquecidas por uma única fonte de calor. As curvas obtidas nesse sistema mostram picos ascendentes que caracterizam eventos exotérmicos, enquanto os descendentes para eventos endotérmicos (MATOS \& MACHADO, 2004).

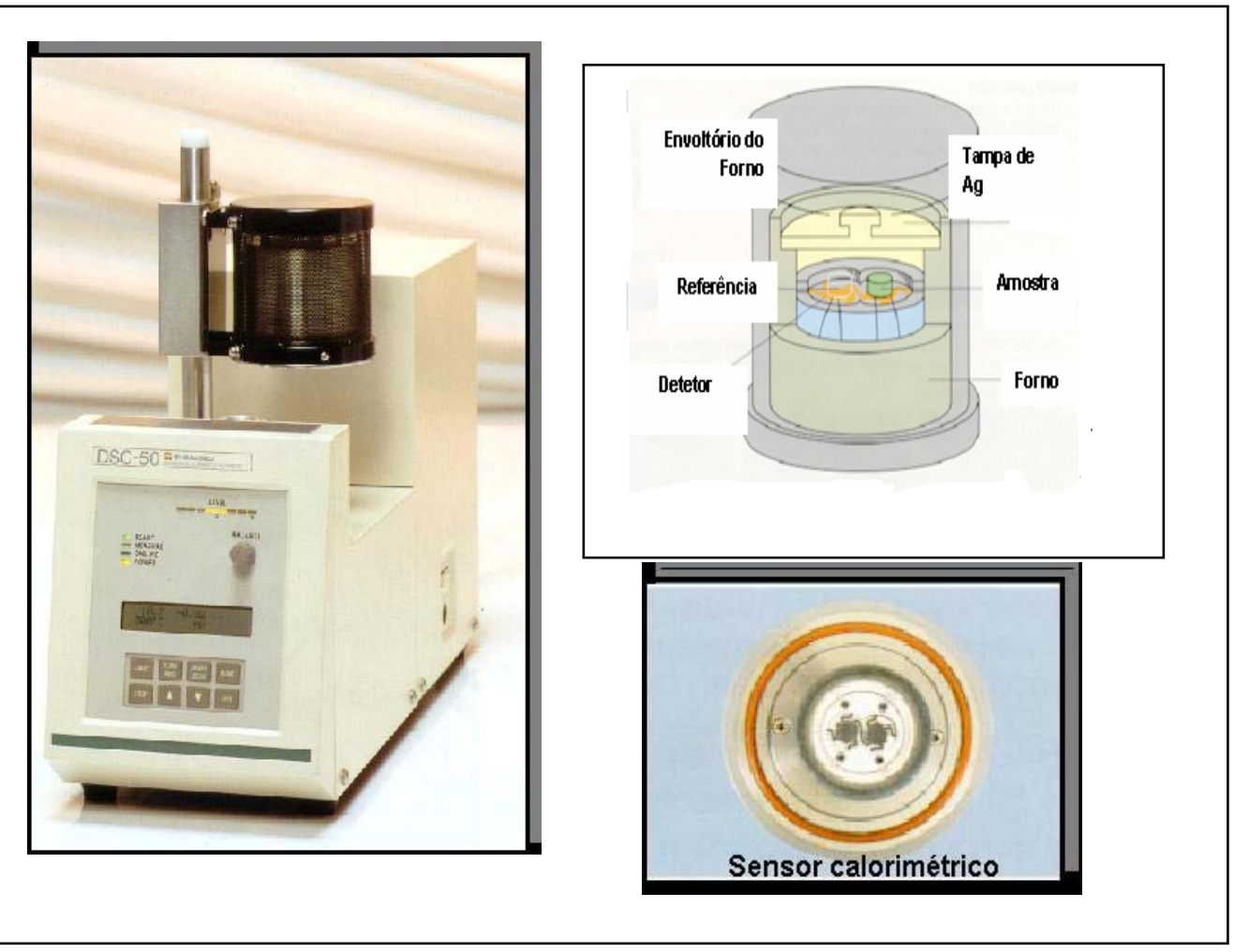

Figura 31. Célula DSC 50 e vista do interior da célula (SHIMADZU, 2004).

\subsubsection{Análise Térmica aplicada à cosmetologia}

MOTHÉ e colaboradores, realizaram o estudo termoanalítico (TG/DTG) de um creme anticelulite à base de Gingko biloba, Centella asiática e Fucus vesiculosus. A técnica auxiliou no estudo da estabilidade térmica e da composição do produto (MOTHÉ et al, 2006).

GUILLEN, BATISTA e MATOS, avaliaram o comportamento térmico das substâncias DMAE e ácido ascórbico isoladamente e incorporados em emulsões ou géis. Os autores utilizaram a DSC, a TG e DTG, e os resultados foram importantes para 
confirmar o grau de pureza destas substâncias, além de contribuir para os estudos de préformulação. Segundo os autores, a previsão da estabilidade térmica dos componentes pode auxiliar no controle dos parâmetros dos processos industriais. Isoladamente, o ácido ascórbico foi a substância que apresentou a maior estabilidade (GUILLEN, BATISTA e MATOS et al, 2006).

SILVA, avaliou por meio da análise térmica o comportamento térmico de emulsões O/A diferenciando as águas livre e interlamelar. As curvas de DSC caracterizam a libertação de água nos sistemas, mostrando-se compatíveis com as perdas de massa das curvas TG (SILVA, 1995).

\subsubsection{Análise do tamanho de partícula}

Com base na análise da caracterização das partículas, há a possibilidade do modelamento teórico de materiais. Com o atual avanço nos computadores modernos, cada vez mais é possível a previsão teórica do comportamento e das propriedades dos novos materiais o que diminui e facilita os procedimentos experimentais para o seu desenvolvimento. Para tanto, porém, os dados e as informações que alimentam os modelos propostos devem ter a maior exatidão possível (PAPINI, 2003).

A determinação de valores exatos de tamanho de partícula é extremamente difícil e encontra obstáculos diferentes para cada uma das técnicas. Por essa razão, para medidas de controle de processo a reprodutibilidade passa a ser mais importante, porém no desenvolvimento de novos produtos, a exatidão da análise pode ser fundamental (PAPINI, 2003). 
Como cada técnica de análise é baseada em princípios físicos diferentes, os resultados obtidos por essas análises podem ser diferentes. Além disso, os fabricantes de equipamentos de análise usam projetos de construção distintos, o que também pode acarretar resultados diferentes mesmo entre equipamentos que utilizam o mesmo princípio básico (PAPINI, 2003).

Outro fator de grande importância a ser considerado na determinação da distribuição de tamanho de partícula é qual dimensão da partícula está sendo medida. Uma esfera pode ter seu tamanho definido por um único valor: o diâmetro. Porém, partículas com formatos irregulares necessitam de mais de uma medida para a quantificação do seu tamanho. Para expressar esse valor em um único número, normalmente adota-se o valor de esfera equivalente. Dependendo do que é medido (maior ou menor comprimento, volume, massa, área projetada, velocidade de sedimentação, etc), o diâmetro dessa esfera equivalente apresenta valores diferentes. A Figura 32 ilustra alguns dos diâmetros médios equivalentes que podem ser gerados a partir de um grão de areia com forma irregular (RAWLE, 2003). 


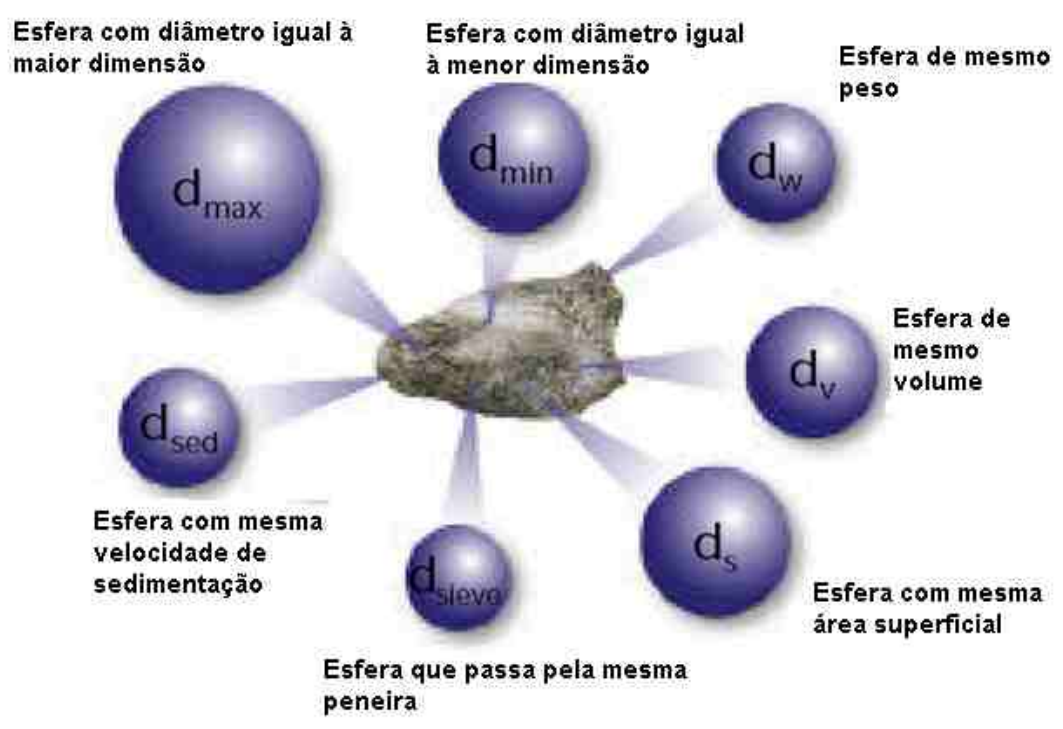

Figura 32. Diferentes diâmetros de esferas equivalentes geradas a partir de uma partícula irregular (RAWLE, 2003).

A medida do tamanho de partícula em materiais farmacêuticos é importante por que influencia propriedades físicas, e determina a habilidade do pó em fluir, misturar, granular e dissolver (NARAYAN \& HANCOCK, 2005).

\subsubsection{Análise da distribuição de tamanho de partícula por difração a laser}

Por sua facilidade de operação, rapidez de análise e ampla faixa de tamanhos. Atualmente, essa é a técnica mais popular para caracterizar distribuições de tamanho de partículas, dispersas em meio líquido ou em forma de pó seco (VASCONCELLOS, 2004).

A difração a laser baseia-se no princípio (difração Fraunhöffer) de que, quanto menor o tamanho da partícula, maior o ângulo de difração de um feixe luminoso que atravessa uma população de partículas. Essa técnica não mede partículas individuais. Com base nas transformações matemáticas complexas (transformada de Fourier 
inversa), calcula-se uma estatística de distribuição de tamanho dessa população de partículas (VASCONCELLOS, 2004; PAPINI, 2002).

Para partículas maiores do que 1mm, o ângulo de difração é extremamente pequeno, sendo crítico o alinhamento e resolução da óptica ( VASCONCELLOS, 2007; PAPINI, 2003).

Em sua faixa ideal de utilização $(5 \mu \mathrm{m}$ a $1.000 \mu \mathrm{m})$, não é necessário conhecer as propriedades ópticas da amostra nem do meio. A equação de Fraunhöffer é uma simplificação da equação de Mie, válida para partículas bastante maiores do que o comprimento de onda da luz utilizada (600 a $800 \mathrm{~nm}$, na maioria dos equipamentos comerciais) (VASCONCELLOS, 2007; PAPINI, 2003). A Figura 33 mostra o esquema de um equipamento de análise de tamanho de partícula por difração a laser.

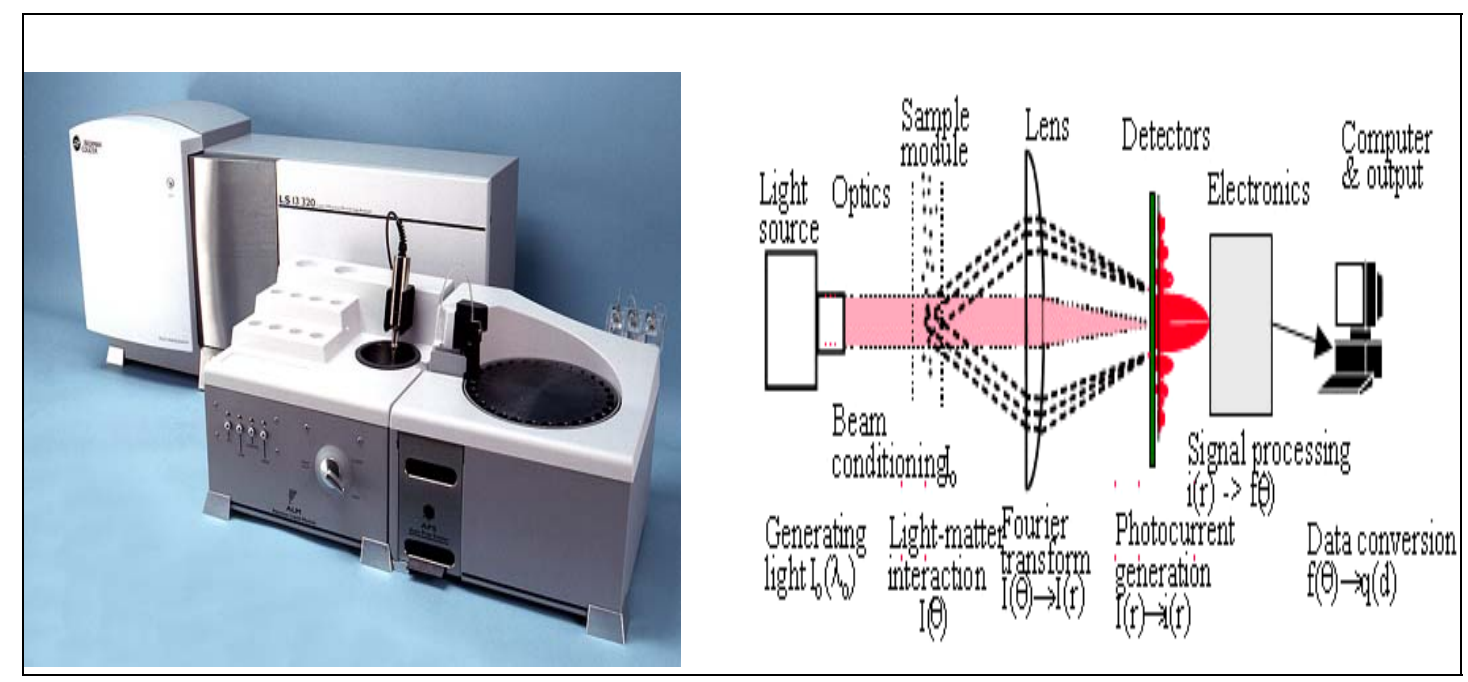

Figura 33. Esquema de um equipamento de análise de tamanho de partícula por difração a laser (BECKMANN COULTER, 2004). 
Abaixo de $5 \mu \mathrm{m}$, é necessário considerar o índice de refração e de extinção das partículas e usar-se a equação de Mie para se obter resultados quantitativos confiáveis para partículas esféricas (VASCONCELLOS, 2004; PAPINI, 2002).

\subsubsection{Espalhamento Dinâmico de Luz (DLS)}

O espalhamento dinâmico de luz (DLS) é uma técnica não invasiva para a medição do tamanho de partículas, tipicamente com tamanho menor de $1 \mu \mathrm{m}$. Partículas em suspensão apresentam um movimento denominado browniano. Se essas partículas são iluminadas por um feixe de luz laser, ocorre o espalhamento da luz. A intensidade da luz espalhada, detectada num ângulo determinado, varia numa taxa dependente da velocidade de difusão da partícula, a qual, por sua vez, é governada pelo seu tamanho. Dados do tamanho da partícula podem ser gerados a partir da análise da variação na intensidade da luz espalhada (PECORA, 1985).

Em equipamentos convencionais de DLS (Figura 34), a luz é espalhada pelas partículas em todos os ângulos, porém é detectada apenas em um, convencionalmente de $90^{\circ}$. As informações sobre o tamanho das partículas são geradas a partir desses dados (KASZUBA, CONNAH \& MATTISON, 2004). 


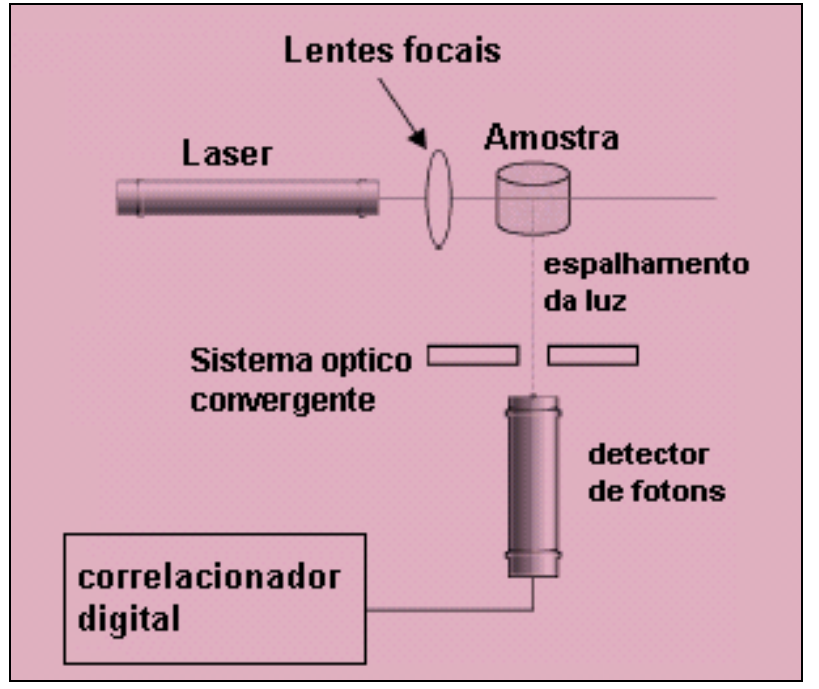

Figura 34. Diagrama esquemático de um DLS realizado a $90^{\circ}$ (KASZUBA, CONNAH \& MATTISON, 2004).

O sistema de medição não invasivo por "backscatter optics" (NIBS) permite que concentrações maiores da amostra sejam analisadas sem ocorrer o efeito de espalhamento múltiplo comumente ocorrido em medidas convencionais num ângulo de $90^{\circ}$, quando altas concentrações da amostra são submetidas à análise. No espalhamento múltiplo da luz, a luz espalhada por uma partícula é espalhada novamente por outra antes de chegar ao detector, ocasionando uma redução no tamanho aparente da amostra. Medindo-se num ângulo de $173^{\circ}$ ao invés de $90^{\circ}$, o feixe de luz incidente e o espalhamento de luz detectado não precisam atravessar totalmente a amostra. Primeiramente, isto reduz a chance de que os fótons incidentes e espalhados encontrem mais de uma partícula, reduzindo a chance de espalhamento múltiplo. Em segundo, como partículas grandes tendem a espalhar luz principalmente na direção frontal, e contaminantes na amostra são relativamente grandes, os efeitos desses, tais como poeira, são fortemente reduzidos (KASZUBA, CONNAH \& MATTISON, 2004).

As concentrações das amostras a serem analisadas podem ser satisfatoriamente aumentadas através da mudança na posição de medição na cubeta. Isso é alcançado 
movimentando-se as lentes focais, conforme apresentado na Figura 35. Para partículas pequenas ou amostras de baixa concentração, é necessário que se maximize a quantidade de luz espalhada pela amostra e, nesse sentido, a posição de medição mais eficaz é aquela realizada em direção ao centro da cubeta (Figura 35a). Para partículas grandes ou amostras de alta concentração, que espalham mais luz a posição de medição mais eficaz é aquela realizada próxima à parede da cubeta (Figura 35b), reduzindo assim a chance de espalhamento múltiplo de luz.

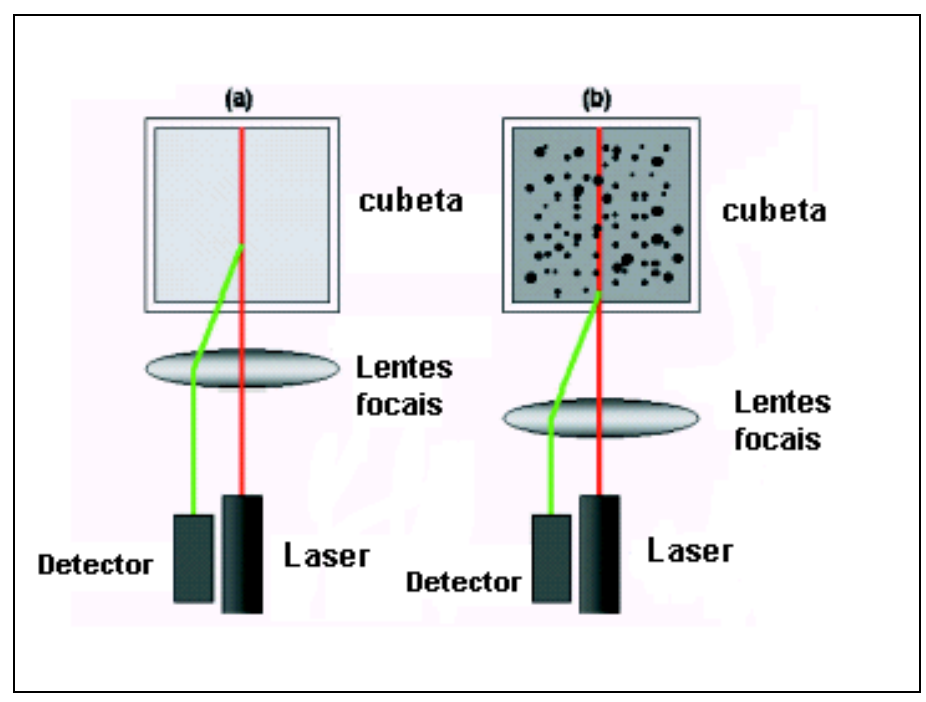

Figura 35. Diagrama esquemático mostrando a posição de medição para: (a) amostras pequenas e que espalham pouco a luz; (b) amostras concentradas e opacas, que espalham bastante a luz (KASZUBA, CONNAH \& MATTISON, 2004).

\subsection{Avaliação do potencial Antioxidante in vitro}

\subsubsection{Determinação da atividade antioxidante pela reação com DPPH (2,2' '-difenil-1- picrilhidrazil)}

Atualmente, existe um aumento no uso e na mensuração da atividade antioxidante em alimentos, medicamentos e cosméticos. O método de determinação da atividade antioxidante in vitro de compostos, pela reação com DPPH (2,2'-difenil-1-picrilhidrazil) 
foi inicialmente descrito por Brand-Williams et al e apresenta como fundamento a redução do radical 2,2'-difenil-1-picrilhidrazil, o qual apresenta um máximo de absorção em 517 nm. Com base no decaimento da absorbância, pode-se avaliar a presença de compostos capazes de doar H. ou seqüestrar o radical, que após o equilíbrio da reação permite calcular a quantidade de antioxidante gasta para reduzir 50\% do DPPH (BUENGER et al, 2006; BRAND-WILLIAMS et al, 1995).

BONINA et al, 1998 avaliaram a atividade antioxidante in vitro usando o método de DPPH e in vivo do "red orange extract" e a substância apresentou forte atividade antioxidante e uma excelente aplicação para cosméticos com finalidade antienvelhecimento e pós-sol .

\subsubsection{Determinação do potencial antioxidante por fluorescência - ORAC (Oxigen Radical Absorbance Capacity Assay).}

O método da determinação por fluorescência do potencial antioxidante - ORAC (Oxigen Radical Absorbance Capacity Assay) baseia-se na análise de solução de fluoresceína, adicionado por uma solução de AAPH (2,2'azobis (2-amidinopropane) dihydrochloride), gerador de radical livre que reage com a fluoresceína, consumindo-a. Com base na medida de intensidade de fluoresceína, obtêm-se a capacidade antioxidante da amostra, sendo que na presença de compostos antioxidantes o decaimento da fluorescência é inibido (OU \& WOODILL-HAMPSCH \& PRIOR, 2001).

\subsection{Estabilidade de formulações cosméticas}

Os testes de estabilidade devem ser conduzidos sob condições que permitam fornecer informações sobre a estabilidade do produto no menor tempo possível (BABY et al, 2004). 
Existe um número de fatores que afetam a estabilidade das emulsões, incluindo o método de preparação, a natureza das matérias-primas, os efeitos dos eletrólitos, volume das fases, concentração e tipo dos emulsificantes (ÖZER et al, 2000).

O critério que controla a qualidade das formulações cosméticas são as propriedades físicas e estabilidade. Mudanças nas propriedades reológicas representam um aviso importante para impedir a falha de um produto. As emulsões são sistemas termodinamicamente instáveis. As fontes da instabilidade das emulsões são comuns para todos os sistemas dispersos e os agravantes da instabilidade são cremeação, floculação e coalêscencia das gotículas oleosas. Assim, a estabilidade representa um importante fator que pode ser percebido pelo consumidor, sendo que a desestabilização do sistema pode acarretar a perda das propriedades das emulsões (MOSTEFA et al, 2006).

Ao se iniciar a avaliação de estabilidade, o formulador deve planejar e sistematizar o estudo, por exemplo, qual a quantidade (massa ou volume) do produto que é necessária para a realização de todos os ensaios que foram pré-determinados, como: determinação do valor de $\mathrm{pH}$; viscosidade aparente; características organolépticas e quantificação do teor de substância. Quanto ao material de acondicionamento, pode-se utilizar o vidro e/ou o final (BABY et al, 2004).

O estudo da estabilidade preliminar consiste na realização do teste na fase inicial do desenvolvimento do produto; utilizando-se diferentes formulações de laboratório e com duração reduzida. Empregam-se condições extremas de temperatura com objetivo de acelerar as possíveis reações entre seus componentes e o surgimento de sinais que devem ser observados e analisados conforme as características específicas de cada produto (BABY et al, 2004). 
A estabilidade acelerada, também conhecida como Estabilidade Normal ou Exploratória, tem como objetivo fornecer dados para prever a estabilidade do produto, tempo de vida útil e compatibilidade da formulação com o material de acondicionamento. Recomenda-se que as amostras para avaliação da estabilidade sejam acondicionadas em frasco de vidro neutro, transparente, com tampa que garanta uma boa vedação evitando perda de gases ou vapor para o meio. Se houver incompatibilidade conhecida entre os componentes das formulações e o vidro, o formulador deve selecionar outro material de acondicionamento. Deve-se evitar a incorporação de ar no produto, durante o envase no recipiente de teste. É importante não completar o volume total da embalagem permitindo um espaço vazio de aproximadamente $1 / 3$ da capacidade do frasco para possíveis trocas gasosas (BRASIL-ANVISA, 2004).

A duração do teste de estabilidade acelerada é de geralmente, 90 dias e as formulações em teste são submetidas a condições menos extremas que no teste de Estabilidade Preliminar. As amostras podem ser submetidas a aquecimento em estufas, resfriamento em refrigeradores, exposição à radiação luminosa e ao ambiente A periodicidade da avaliação das amostras pode variar conforme experiência técnica, especificações do produto, características especiais de algum componente da formulação ou sistema conservante utilizado, porém o mais usual nesse estudo acelerado é que sejam avaliadas inicialmente no tempo zero, 24 horas e aos $7^{\circ}, 15^{\circ}, 30^{\circ}, 60^{\circ}$ e $90^{\circ}$ dias (BRASILANVISA, 2004).

\subsection{Microscopia}

É uma técnica de medida direta, para a observação da partícula no microscópio, a amostra é depositada sobre uma lâmina, e observada em microscópio óptico (luz refletida 
ou transmitida ou eletrônica, varredura ou transmissão). A microscopia é usada na caracterização e observação da variação morfológica das partículas (NARAYAN \& HANCOCK, 2005).

\subsection{Cromatografia Liquida de Alta Eficiência (CLAE)}

A cromatografia pode ser conceituada como um método físico-químico de separação, no qual os constituintes da amostra a serem separados são particionados em duas fases, uma estacionária, geralmente de grande área, e a outra um fluído insolúvel na fase estacionária, que percorre a primeira. A fase estacionária, ou adsorvente, tem tomado várias formas no decorrer do tempo, incluindo papel, camada delgada de sólidos sobre placa de vidro, líquidos imobilizados, géis e partículas sólidas empacotadas em colunas. O componente que flui, ou fase móvel, é um líquido ou um gás (WESTON \& BROWN, 1997).

$\mathrm{Na}$ cromatografia de alta eficiência, surgida na década de 60 , a enorme variedade de fases estacionárias disponíveis (colunas) e a ampla faixa de temperatura utilizada permitem uma grande variação no tipo de interação específica, multiplicando as possibilidades de separação. O método permite o uso de vários tipos de detectores: UVVIS, PDA, eletroquímico, fluorescência, índice de refração, espectrometria de massas, etc (SNYDER, KIRKLAND \& GLAJCH, 1997).

$\mathrm{Na}$ cromatografia de pareamento iônico o pH da fase móvel é ajustado de modo a “encorajar” a ionização da amostra. A retenção é alcançada pela introdução de um reagente de pareamento iônico no eluente, uma molécula orgânica dotada de carga positiva (separação de ácidos) ou de carga negativa (separação de bases). A amostra interage com o 
contra-íon do pareador e o par iônico formado terá maior afinidade pela coluna de fase reversa em função da hidrofobicidade da cadeia carbônica do reagente pareador (SNYDER, KIRKLAND \& GLAJCH, 1997).

Alguns mecanismos são postulados na tentativa de explicar a forma como ocorre à interação entre pareador, analito e fase estacionária. Além de outros mais complexos (formação de micelas, complexação), os mecanismos fundamentais envolveriam a interação do pareador com o analito ionizado já na fase móvel e a posterior partição do par não carregado com a fase estacionária e/ou então a interação do pareador com a fase estacionária, expondo sua carga para a superfície e a posterior interação do analito de carga oposta que passa pela coluna, o que se assemelharia com o mecanismo da cromatografia de troca iônica (SNYDER, KIRKLAND \& GLAJCH , 1997).

Na cromatografia do pareamento iônico, a retenção e separação são influenciadas pelo $\mathrm{pH}$ e concentração do tampão, tamanho e concentração do reagente de pareamento, tipo e concentração do reagente de pareamento, tipo e concentração do solvente orgânico e fase estacionária utilizada (SNYDER, KIRKLAND \& GLAJCH , 1997).

\subsection{Validação de Métodos Analíticos}

Os parâmetros analíticos preconizados pela ICH (International Conference on Harmonization), instrumento Q2(R1) -Validation of analytical procedures: text and methodology (novembro, 2005) e da USP 30 ed, para validação de métodos analíticos são: exatidão; precisão; especificidade ou seletividade; linearidade; limites de detecção e quantificação; robustez e resistência. 


\section{a) Especificidade ou Seletividade:}

Um método é considerado específico quando mede com exatidão a substância analisada, na presença de outros componentes.

\section{b) Linearidade:}

A linearidade de um método analítico pode ser determinada através da análise de regressão linear a fim de determinar se há relação linear entre a resposta instrumental e a concentração conhecida da substância presente nas amostras, ou seja, demonstra a capacidade do método gerar resultados diretamente proporcionais à concentração da substância em exame dentro de uma variação conhecida.

\section{c) Precisão:}

O coeficiente de variação, expresso em porcentagem, ou desvio padrão médio relativo determina a variação limite da análise. Geralmente, é calculado mediante dez determinações para cada uma das concentrações estudadas.

\section{d) Exatidão:}

O percentual de recuperação expressa a concordância dos valores teóricos e os experimentais obtidos com o emprego do método que está sendo proposto; assim, ao serem adicionadas concentrações conhecidas da substância analisada, após análise dessa amostra é possível determinar quanto o método foi capaz de analisar .

\section{e) Limites de Detecção e Quantificação:}

O limite de detecção de um método analítico corresponde á mais baixa concentração da substância presente na amostra que pode ser detectada com certo limite de confiabilidade e o limite de quantificação de um método analítico corresponde a mais 
baixa concentração da substância em exame presente na amostra que pode ser exatamente e precisamente medida.

\section{f) Robustez:}

A robustez corresponde a capacidade que o método tem de não ser afetado por uma pequena e deliberada variação em seus parâmetros, por exemplo, $\mathrm{pH}$, temperatura, composição da fase móvel, velocidade de fluxo.

\section{g) Resistência:}

A resistência corresponde ao grau de reprodutibilidade dos resultados obtidos sob uma variedade de condições operacionais e ambientais do método analítico. 


\section{OBJETIVOS}

\subsection{Objetivo geral:}

Caracterizar e analisar o AMS em formulações cosméticas.

\subsection{Objetivos específicos:}

Caracterizar o ascorbato de monometilsilanotriol empregando as seguintes técnicas: espectrofotometria no ultravioleta, espectrofotometria de absorção na região do infravermelho com transformada de Fourier (FTIR), cromatografia em camada delgada (CCD), calorimetria exploratória diferencial (DSC), termogravimetria (TG)/termogravimetria Derivada (DTG) e análise do tamanho de partícula (ATP);

Avaliar a atividade antioxidante in vitro do AMS por diferentes técnicas;

Desenvolver emulsões cosméticas para incorporação do AMS;

Estudar o comportamento das emulsões base (sem a incorporação do AMS) e comparar com o comportamento das formulações com a incorporação do AMS utilizando as seguintes técnicas: calorimetria exploratória diferencial (DSC), análise de tamanho de partícula por difração a laser (ATP-DL) e microscopia de luz polarizada;

Avaliar a estabilidade física das emulsões baseada na avaliação dos seguintes parâmetros: caracteres organololépticos, $\mathrm{pH}$ e viscosidade.

Desenvolvimento de método analítico para separação e quantificação do AMS nas diferentes formulações cosméticas. 


\section{MATERIAL E MÉTODOS}

\subsection{MATERIAL}

\subsubsection{Matérias-primas empregadas no desenvolvimento das formulações}

\subsubsection{Umectantes}

I. Glicerina Bi-Destilada ${ }^{\circledR}$ : foi adquirida da empresa Polytechno, apresentando grau de pureza farmacêutico. As especificações físico-químicas da Glicerina Bi-Destilada ${ }^{\circledR}$ segundo certificado de análise fornecido pela Polytechno são as seguintes:
a) INCI name: Glycerin
b) Aspecto $\left(25^{\circ} \mathrm{C}\right)$ : líquido viscoso;
c) Cor: amarelo alaranjado
d) Odor: característico;
e) Densidade $\left(25^{\circ} \mathrm{C}\right): 1,26 \mathrm{~g} / \mathrm{cm}^{3}$.

II. Glucam E-20 ${ }^{\circledR}$ (derivado alcoxilado de glucose): foi adquirido da empresa Polytechno, possuindo grau de pureza farmacêutico. As especificações físico-químicas do Glucam E$20^{\circledR}$ segundo certificado de análise fornecido pela Polytechno são as seguintes:
a) INCI name: Methyl Gluceth - 20;
b) Aspecto $\left(25^{\circ} \mathrm{C}\right)$ : líquido;
c) Cor: amarelo palha;
d) Odor: característico;
e) Densidade $\left(25^{\circ} \mathrm{C}\right): 1,20 \mathrm{~g} / \mathrm{cm}^{3}$;
f) Índice de Acidez: 1,0 mg KOH/g amostra;
g) Índice de Iodo: 1,0 g/I/100 g amostra; 
h) Índice de Saponificação: 1,0 mg/KOH/g amostra.

III. Hidraction NMF: foi adquirido da empresa Bioextract ${ }^{\circledR}$ Farma Service, possuindo grau de pureza farmacêutico. As especificações físico-químicas do Hidraction NMF segundo certificado de análise fornecido pela Bioextract ${ }^{\circledR}$ Farma Service Polytechno são as seguintes:

a) INCI name: Hidraction NMF;

b) Aspecto $\left(25^{\circ} \mathrm{C}\right)$ : líquido de baixa viscosidade ligeiramente opalescente;

c) Cor: incolor;

d) Odor: característico suave;

e) $\mathrm{pH}\left(25^{\circ} \mathrm{C}\right): 5,0$;

f) Índice de Refração $\left(25^{\circ} \mathrm{C}\right): 1,378$;

g) Densidade $\left(25^{\circ} \mathrm{C}\right): 1,088 \mathrm{~g} / \mathrm{cm}^{3}$.

IV. Propilenoglicol: foi adquirido da empresa Polytechno, possuindo grau de pureza farmacêutico. As especificações físico-químicas do Propilenoglicol segundo certificado de análise fornecido pela Polytechno são as seguintes:

a) INCI name: Propyleneglicol;

b) Aspecto $\left(25^{\circ} \mathrm{C}\right)$ : líquido incolor;

c) $\mathrm{pH}\left(25^{\circ} \mathrm{C}\right): 6,0$;

d) Índice de Refração: 1,4310;

e) Densidade $\left(25^{\circ} \mathrm{C}\right): 1,036 \mathrm{~g} / \mathrm{cm}^{3}$.

4.1.1.2. Surfactantes poliméricos e Espessantes orgânicos solúveis em água (não iônicos)

I. Methocel ${ }^{\circledR}$ 40-101 (Hidroxipropilmetilcelulose): foi adquirido da empresa Dow Chemical apresentando grau de pureza farmacêutico. É um polímero, utilizado como 
espessante orgânico em formulações. Ele forma uma estrutura coloidal que impede a mobilidade e coalescência dos glóbulos da emulsão, e também adsorvem na superfície das partículas da fase dispersa, formando um filme interfacial que age por barreiras de repulsão elétrica e por impedimento estérico, evitando a aproximação dos glóbulos e a separação de fases. As especificações físico-químicas do Methocel $^{\circledR}$ 40-101 segundo certificado de análise fornecido pela Dow Chemical são as seguintes:

a) INCI name: Hydroxypropyl Methylcellulose;

b) Aspecto: pó;

c) Cor: branco;

d) Viscosidade aparente (solução à 2\%): 75.000 mPas.s.

Sepigel ${ }^{\circledR}$ 305: foi adquirido da empresa Seppic apresentando grau de pureza farmacêutico. É utilizado como polímero emulsionante, espessante e estabilizante para emulsões e géis creme. As especificações físico-químicas do Sepigel ${ }^{\circledR} 305$ segundo certificado de análise fornecido pela Seppic são as seguintes:

a) INCI name: Polyacrylamide and $\mathrm{C}_{13-14}$ Isoparaffin and Laureth-7;

b) Aspecto $\left(25^{\circ} \mathrm{C}\right)$ : emulsão fluída;

c) Cor: branca;

d) Viscosidade aparente (solução à 2\%): 60.000 - 90.000 mPas.s.;

e) $\mathrm{pH}: 6,0$.

\subsubsection{Tensoativos não iônicos hidrófilos}

I. Sorbiex ${ }^{\circledR} 60$ (Monoestearato de Sorbitan Etoxilado $(20 \mathrm{OE})$ ) : foi adquirido da empresa Polytechno apresentando grau de pureza farmacêutico. É um tensoativo não iônico derivado de pólios, sendo assim a presença da cadeia de polioxietileno faz com que o Sorbiex ${ }^{\circledR} 60$ seja solúvel em água, o que favorece a sua aplicação em emulsões O/A. As 
especificações físico-químicas do o Sorbiex ${ }^{\circledR} 60$ segundo certificado de análise fornecido pela Polytechno são as seguintes:

a) INCI name: Polysorbate 80;

b) Aspecto $\left(25^{\circ} \mathrm{C}\right)$ : líquido pastoso;

c) Cor: amarelada;

d) Odor: característico;

e) Índice de Hidroxila: $81 \mathrm{mg} \mathrm{KOH} / \mathrm{g}$ amostra;

f) Índice de Saponificação: $45 \mathrm{mg} \mathrm{KOH/g} \mathrm{amostra.}$

\subsubsection{Quelantes}

I. Versene ${ }^{\circledR} \mathbf{N a}_{2}$ : foi adquirido da empresa Dow apresentando grau de pureza farmacêutico. É um agente quelante e é extremamente eficaz em sistemas com pH ácidos. As especificações físico-químicas do $\operatorname{Versene}^{\circledR} \mathrm{Na}_{2}$ segundo certificado de análise fornecido pela Dow são as seguintes:

a) INCI name: Dissodium EDTA;

b) Aspecto $\left(25^{\circ} \mathrm{C}\right)$ : cristais;

c) Cor: branco;

d) $\mathrm{pH}\left(25^{\circ} \mathrm{C}\right)$ solução a 5\%: 4,4.

\subsubsection{Conservantes}

I. Phenoben $^{\circledR}$ : foi adquirido da empresa Bioextract ${ }^{\circledR}$ Farma Service apresentando grau de pureza farmacêutico. É um agente conservante de largo espectro de ação contra fungos, leveduras e bactérias. É uma solução de parabenos (metilparabeno, propilparabeno, etilparabeno, butilparabeno) em fenoxietanol. Ele é compatível com a maioria dos compostos químicos, não causando alterações de cor, viscosidade, $\mathrm{pH}$ e odor, sendo compatível com sistemas aniônicos e mantém sua ação em condições de pH ácido, neutro e 
alcalino. As especificações físico-químicas do Phenoben ${ }^{\circledR}$ segundo certificado de análise fornecido pela Bioextract ${ }^{\circledR}$ Farma Service são as seguintes:

a) INCI name: sendo o Phenoben uma solução contendo ésteres de parabenos em fenoxietanol. Os ésteres de parabenos presentes na solução apresentam os seguintes INCI names: Phenoexyethanol, Methylparaben; Ethylparaben; Propylparaben e Butylparaben; Aspecto $\left(25^{\circ} \mathrm{C}\right)$ : líquido de baixa viscosidade transparente;

b) Cor: incolor;

c) Odor: característico suave;

d) Densidade $\left(25^{\circ} \mathrm{C}\right): 1,115 \mathrm{~g} / \mathrm{cm}^{3}$;

e) Índice de Refração $\left(25^{\circ} \mathrm{C}\right): 1,500$;

f) Contagem microbiana: bactérias: máximo $100 \mathrm{col} / \mathrm{g}$;

g) Contagem microbiana: fungos: máximo $100 \mathrm{col} / \mathrm{g}$.

\subsubsection{Veículo}

I. Água destilada : o veículo empregado para as formulações desenvolvidas foi água destilada recém obtida.

\subsubsection{Extratos vegetais solúveis em água}

I. Protrigo ${ }^{\circledR}$ : foi adquirido da empresa Bioextract ${ }^{\circledR}$ Farma Service apresentando grau de pureza farmacêutico. É uma proteína hidrolisada de trigo que contém peptídeos vegetais originárias do trigo. O processo de hidrólise é conduzido de forma a assegurar homogeneidade de peso molecular dos peptídeos, para utilização em produtos de uso tópico. As especificações físico-químicas do Protrigo ${ }^{\circledR}$ segundo certificado de análise fornecido pela Bioextract ${ }^{\circledR}$ Farma Service são as seguintes:

a) INCI name: Hydrolyzed Wheat Protein;

b) Aspecto $\left(25^{\circ} \mathrm{C}\right)$ : líquido de baixa viscosidade; 
c) Cor: amarelo claro a ocre;

d) Odor: característico suave;

e) $\mathrm{pH}\left(25^{\circ} \mathrm{C}\right): 5,2$;

f) Densidade $\left(25^{\circ} \mathrm{C}\right): 1,028 \mathrm{~g} / \mathrm{cm}^{3}$;

g) Índice de Refração $\left(25^{\circ} \mathrm{C}\right): 1,352$.

II. Ginkgo Biloba extrato vegetal tipo hidroglicólico (HG): foi adquirido da empresa Bioextract ${ }^{\circledR}$ Farma Service apresentando grau de pureza farmacêutico. O Ginkgo biloba contém flavonóides (quercetina, campferol) e isoramnetina, glicosídeos (quercitrina, isoquercitrina, rutina, astragalina, dihidrocampferol-O-glucosídeo, isoramnetina-Orutinosídeo, luteolina). Bioflavonóides: amntoflavona, bilobetina, metoxibilobetina, ginkgetina, isoginkgetina e sciadopitisina. Ginkgolídeos A,B,C; bilobalide; ácidos (ginkgólico, hidroxiquinurênico, clorogênico, p-cumarínico, vanílico). Catequina, taninos e epigalocatequina. O Ginkgo biloba é sequestrante de radicais livres, restaurador das funções vitais dos tecidos. Inibe a destruição do colágeno e a despolimerização do ácido hialurônico. As especificações físico-químicas do Ginkgo Biloba Extrato Vegetal Tipo Hidroglicólico (HG) segundo certificado de análise fornecido pela Bioextract ${ }^{\circledR}$ Farma Service são as seguintes:

a) INCI name: Ginkgo Biloba Leaf Extract;

b) Aspecto $\left(25^{\circ} \mathrm{C}\right)$ : líquido de baixa viscosidade;

c) Cor: âmbar claro a ocre;

e) Densidade ( $\left.25^{\circ} \mathrm{C}\right): 1,010$;

f) Índice de Refração: 1,400 . 


\subsubsection{Emolientes}

I. Lipex ${ }^{\circledR}$ Shea WL : foi adquirido da empresa Polytechno apresentando grau de pureza farmacêutico. Ele é um produto derivado da manteiga de Karité com excelentes propriedades emolientes e hidratantes, proporcionando maciez e sensorial superior para a pele. As especificações físico-químicas do Lipex ${ }^{\circledR}$ Shea WL segundo certificado de análise fornecido pela Polytechno são as seguintes:

a) INCI name: Shea Butter Oleyl Esters;

b) Aspecto $\left(25^{\circ} \mathrm{C}\right)$ : líquido;

c) Cor: amarela;

d) Índice de Acidez: máximo 1,0 mg KOH/g amostra;

e) Índice de Saponificação: $98,10 \mathrm{mg} / \mathrm{KOH} / \mathrm{g}$ amostra.

II. Polygreen ${ }^{\circledR}$ Oliva OI : foi adquirido da empresa Polytechno apresentando grau de pureza farmacêutico e se enquadra nas especificações da monografia da Pharmacopeia Européia para o óleo de oliva refinado. O óleo de oliva é caracterizado por triglicerídeos com alto teor de ácido graxo oléico. Com base em um processo original de refino, apresenta ainda um teor de esqualeno e fitoesteróis. Tanto o esqualeno, quanto os tocoferóis naturais, principalmente o alpha-tocoferol (vitamina E), atuam como antioxidantes. O Polygreen ${ }^{\circledR}$ Oliva Ol apresenta propriedades emolientes e auxilia na restauração do manto hidro-lipídico, preservando a maciez e suavidade da pele, prevenindo e combatendo o ressecamento. As especificações físico-químicas do Polygreen ${ }^{\circledR}$ Oliva O1 segundo certificado de análise fornecido pela Polytechno são as seguintes:

a) INCI name: Olea europaea (olive) oil;

b) Aspecto $\left(25^{\circ} \mathrm{C}\right)$ : líquido límpido;

c) Cor: amarela à esverdeada; 
d) Densidade $\left(25^{\circ} \mathrm{C}\right)$ : 0,919;

e) Índice de Acidez: máximo 1,0 mg KOH/g amostra;

f) Índice de Iodo: $75 \mathrm{~g} / \mathrm{I} / 100 \mathrm{~g}$ amostra;

g) Índice de Saponificação: 190,0 mg/KOH/g amostra.

III. Óleo de Macadâmia : foi adquirido da empresa Bioextract ${ }^{\circledR}$ Farma Service apresentando grau de pureza farmacêutico. É um óleo natural lubrificante, emoliente, nutritivo e formador de filme protetor. As especificações físico-químicas do Óleo de Macadâmia segundo certificado de análise fornecido pela Bioextract ${ }^{\circledR}$ Farma Service são as seguintes:

a) INCI name: Macadamia Ternifolia Seed Oil;

b) Aspecto $\left(25^{\circ} \mathrm{C}\right)$ : líquido de baixa viscosidade;

c) Cor: amarelo claro;

d) Odor: suave, característico;

e) Densidade $\left(25^{\circ} \mathrm{C}\right)$ : 0,905;

f) Índice de Acidez: máximo 0,02 mg KOH/g amostra;

g) Índice de Iodo: $72 \mathrm{~g} / \mathrm{I} / 100 \mathrm{~g}$ amostra;

h) Índice de Saponificação: 190,0 mg/KOH/g amostra;

i) Índice de Refração: 1,440.

IV. Dow Corning ${ }^{\circledR}$ 245: foi adquirido da empresa Dow Corning apresentando grau de pureza farmacêutico. É um silicone volátil, de baixa viscosidade que possui propriedades lubrificantes e excelente espalhabilidade. Deve ser incorporado a frio na formulação. As especificações físico-químicas do Dow Corning ${ }^{\circledR} 245$ segundo certificado de análise fornecido pela Dow Corning são as seguintes: 
a) INCI name: Cyclopentasiloxane;

b) Aspecto $\left(25^{\circ} \mathrm{C}\right)$ : líquido;

c) Cor: incolor;

d) Odor: característico;

e) Índice de Refração $\left(25^{\circ} \mathrm{C}\right): 1,397$.

\subsubsection{Antioxidantes}

I. BHT Cristal : foi adquirido da empresa Polytechno apresentando grau de pureza farmacêutico. É um antioxidante não clássico que auxilia na estabilização da vitamina $\mathrm{A}$ e E, de óleos, gorduras, ceras e de carotenóides e é muito estável durante a estocagem por não reagir diretamente com o oxigênio gasoso. As especificações físico-químicas do BHT Cristal segundo certificado de análise fornecido pela Polytechno são as seguintes:

a) INCI name: BHT (Butyl Hydroxytoluene);

b) Aspecto: cristais;

c) Cor: branca;

d) Pureza: 99,20\%.

\subsubsection{Espessantes Orgânicos de Fase Oleosa e Co-emulsionantes}

I. Álcool C1618 S: foi adquirido da empresa Polytechno apresentando grau de pureza farmacêutico. É um agente espessante e sobreengordurante para cremes. As especificações físico-químicas do Álcool C1618 S segundo certificado de análise fornecido pela Polytechno são as seguintes:

a) INCI name: Cetearyl Alcohol;

b) Aspecto: escamas;

c) Cor: branca;

d) Odor: característico; 
e) Índice de Acidez: máximo 0,5 mg KOH/g amostra.

II. Lipex ${ }^{\circledR}$ Shea W: foi adquirido da empresa Polytechno apresentando grau de pureza farmacêutico. É derivado da manteiga de karité e apresenta propriedade de doador de viscosidade quando usado em cremes e possui propriedades de formação de filme emoliente, auxiliando na retenção de umidade na pele, reduzindo a perda transepidérmica de água. As especificações físico-químicas do Álcool C1618 S segundo certificado de análise fornecido pela Polytechno são as seguintes:

a) INCI name: Shea Butter Cetyl Esters;

b) Aspecto: sólido ceroso;

c) Cor: branca a lev.amarelada;

d) Odor: característico;

e) Índice de Acidez: máximo 1,00 mg KOH/g amostra;

f) Índice de Saponificação: $95,0 \mathrm{mg} / \mathrm{KOH} / \mathrm{g}$ amostra.

III. Lipex ${ }^{\circledR}$ Shea PEG 7: foi adquirido da empresa Polytechno apresentando grau de pureza farmacêutico. É um éster de poliol obtido a partir da manteiga de karité com excelentes propriedades emoliente, hidratante e co-emulsionante, além de apresentar excelente compatibilidade com a pele. Ajuda a reduzir a irritabilidade dos outros componentes presentes nas formulações. Por ser não iônico, é compatível com tensoativos não-iônicos e aniônicos. As especificações físico-químicas do Lipex ${ }^{\circledR}$ Shea PEG 7 segundo certificado de análise fornecido pela Polytechno são as seguintes:

a) INCI name: PEG-7 Sheabutterate;

b) Aspecto $\left(25^{\circ} \mathrm{C}\right)$ : líquido;

c) Cor: amarelo a âmbar;

d) Índice de Acidez: máximo 5,00 mg KOH/g amostra; 
e) Índice de Saponificação: 70,0 mg/KOH/g amostra.

\subsubsection{Tensoativos não iônicos para componentes oleosos}

I. Lipex ${ }^{\circledR}$ Emulshea: foi adquirido da empresa Polytechno apresentando grau de pureza farmacêutico. É um tensoativo não iônico derivado da manteiga de karité, o qual agrega as características sensoriais de manteiga de karité à capacidade de emulsionar componentes oleosos na elaboração de emulsões em geral. As especificações físico-químicas do Lipex ${ }^{\circledR}$ Emulshea segundo certificado de análise fornecido pela Polytechno são as seguintes:

a) INCI name: PEG-23 Shea butterate;

b) Aspecto $\left(25^{\circ} \mathrm{C}\right)$ : sólido ceroso;

c) Cor: amarela;

d) $\mathrm{pH}$ (solução a 1\%): 5,5;

e) Índice de Acidez: máximo 1,00 mg KOH/g amostra;

f) Índice de Saponificação: 40,0 mg/KOH/g amostra.

\subsubsection{Princípio Ativo}

I. Ascorbato de Monometilsilanotriol (Ascorbosilane $\mathbf{C}^{\circledR}$ ): foi adquirido da empresa Polytechno apresentando grau de pureza farmacêutico. Apresenta-se como solução aquosa contendo $1 \%$ de ascorbato de monometilsilanotriol. As especificações físico-químicas do Ascorbosilane $C^{\circledR}$ segundo certificado de análise fornecido pela Polytechno são:
a) INCI name: Ascorbyl Methylsilanol Pectinate;
b) Aspecto $\left(25^{\circ} \mathrm{C}\right)$ : líquido levemente opalescente;
c) Cor: incolor levemente amarelada;
d) $\mathrm{pH}$ (solução a 1\%): 5,0-7,0;
e) Porcentagem de Ácido Ascórbico: 0,60;
f) Porcentagem de Silício: 0,90. 


\subsubsection{Padrão}

Ácido ascórbico- substância padrão (pureza 99\%) Sigma Chemical Co (St Louis, MO, USA).

\subsubsection{Amostras}

Várias formulações cosméticas na forma de emulsão foram desenvolvidas e vários testes preliminares de estabilidade foram realizados para ajustar a concentração dos tensoativos. As emulsões selecionadas (Tabela 4) foram classificadas como: F1; F1A; F2; F2A; F3 e F3A. Sendo que as formulações F1A; F2A e F3A apresentam 10\% de AMS (solução aquosa a 1\%). Com base na revisão da literatura, foram obtidas formulações que contêm extratos e óleos vegetais que atuam sinergicamente com o AMS, potencializando sua bioatividade. 
Tabela 4. Descrição farmacotécnica das emulsões cosméticas obtidas e avaliadas durante o estudo.

\begin{tabular}{|c|c|c|c|}
\hline \multirow{2}{*}{$\begin{array}{c}\text { Componentes } \\
\text { (nome comercial) }\end{array}$} & \multirow{2}{*}{$\begin{array}{l}\text { Concentração (\%) } \\
\text { F1 } \quad \text { F1 A }\end{array}$} & \multirow{2}{*}{$\begin{array}{c}\text { Concentração (\%) } \\
\text { F2 F2A }\end{array}$} & \multirow{2}{*}{$\begin{array}{l}\text { Concentração (\%) } \\
\text { F3 F3A }\end{array}$} \\
\hline & & & \\
\hline Senige1 305 & 2,5 & - & - \\
\hline Propiletnoglicol & 2,0 & - & - \\
\hline Gluram E & 2,0 & 2,0 & 3,0 \\
\hline Versene $\mathrm{Na}_{2}$ & 0,1 & 0,1 & 0,1 \\
\hline Pró-trigo & 2,0 & 2,0 & 2,0 \\
\hline Hidraction NMF & - & 1,0 & 1,0 \\
\hline Glicerina & - & 2,0 & 2,0 \\
\hline Methocel 40-101 & - & 1,0 & 1,0 \\
\hline Sarbiex 60 & - & - & 3,5 \\
\hline Água destilada & 85,8 & 75,7 & 62,8 \\
\hline Á1coolC1618S & - & 2,5 & 4,0 \\
\hline Linex Shea PEG 7 & - & 1,0 & 2,0 \\
\hline Linex E.mulshea & - & 4,1 & $-\quad-$ \\
\hline Lipex Shea W & -1 & 2,0 & $3,0 \quad 3,0$ \\
\hline Linex Sthea WL & - & $2,0 \quad 2,0$ & - \\
\hline BHT & $0,1 \quad 0,1$ & $0,1 \quad 0,1$ & $0,1 \quad 0,1$ \\
\hline Óleo de maradâmia & $-\quad-$ & - & $2,0 \quad 2,0$ \\
\hline Polvgreen Oliva OL & -320 & - & $3,0 \quad 3,0$ \\
\hline Silicone DC 245 & $5,0 \quad 5,0$ & $2,0 \quad 2,0$ & $2,0 \quad 2,0$ \\
\hline Phenoben & $0,5 \quad 0,5$ & $0,5 \quad 0,5$ & +2 \\
\hline Ext de Ginkge biloba & $-\quad-$ & $2,0 \quad 2,0$ & $-\quad-$ \\
\hline Ascothosilate C (AMS) & $-\quad 10$ & $-\quad 10$ & - \\
\hline
\end{tabular}




\subsubsection{Reagentes, Solventes e Soluções}

AAPH (2,2`- azobis (2-amidinopropane) dihydrochloride (Wako Chemicals ${ }^{\circledR}$ );

Ácido Acético marca Merck ${ }^{\circledR}$;

Ácido Sulfúrico 96 - 98\% grau analítico marca Merck ${ }^{\circledR}$;

Água destilada;

Água MilliQ Plus ${ }^{\circledR}$;

Brometo de tetrabutilamônio 99\% grau analítico marca Sigma-Aldrich ${ }^{\circledR}$;

DPPH (2,2 - difenil-1-picrilhidrazil) 95\% marca Sigma-Aldrich ${ }^{\circledR}$;

Fluoresceína marca Sigma - Aldrich ${ }^{\circledR}$;

Metanol grau cromatográfico marca Merck ${ }^{\circledR}$;

Metanol grau analítico marca Merck ${ }^{\circledR}$;

N - Butanol marca Merck ${ }^{\circledR}$;

Óleo mineral grau de pureza farmacêutico marca Synth ${ }^{\circledR}$;

Reagente de Ninidrina marca Sigma ${ }^{\circledR}$;

Solução de ácido sulfúrico 0,1 N;

Solução de fluoresceína 40 Nm;

Solução tampão fosfato $75 \mathrm{mM}$;

Trolox ${ }^{\circledR}$ marca Sigma - Aldrich

\subsubsection{Equipamentos e Acessórios:}

Agitador mecânico de hélice marca Nova Ética ${ }^{\circledR}$;

Aparelho de ultrassom marca Unique ${ }^{\circledR}$, modelo USC 1450;

Balança analítica modelo AG 200, marca Gehaca ${ }^{\circledR}$; 
Balança Analítica marca Ohaus ${ }^{\circledR}$;

Beckmann Coulter ${ }^{\circledR}$ LS 13320 Laser Diffraction;

Célula DSC 50 marca Shimadzu ${ }^{\circledR}$, modelo DSC 50;

Centrífuga marca Excelsa ${ }^{\circledR}$, modelo 206 MP;

Centrífuga marca Eppendorf ${ }^{\circledR}$ modelo: 5804 R;

Coluna marca Synergi-Hydro ${ }^{\circledR}$ RP Phenomenex 150 X 4,6 mm, partícula de $4 \mu, 80 \AA$ de poro, $\mathrm{C} 18$;

Cromatógrafo Líquido marca Shimadzu ${ }^{\circledR}$, modelo LC-10 AD VC com detector UVVIS, sistema controlador SLC-10 AVP, injeção automática e sistema desgaseificador DGU-14, acoplado ao software Class VP ${ }^{\circledR}$;

Espectrofotômetro UV modelo 1601 - PC, duplo feixe, acoplado a computador e impressora, com cubeta de quartzo com $1 \mathrm{~cm}$ de caminho ótico - Shimadzu ${ }^{\circledR}$;

Espectrofotômetro UV modelo 1601-PC, marca Shimadzu ${ }^{\circledR}$;

Espectrofotômetro Infravermelho marca Bomem $^{\circledR}$ com transformada de Fourier, modelo MB 100;

Estufa com fotoperíodo modelo 131FC, marca Biolabor ${ }^{\circledR}$;

Estufa marca Nova Ética ${ }^{\circledR}$;

Estufa para dessecação, marca Fanem ${ }^{\circledR}$;

Leitor de Placas Multi Detection Microplate Reader, Synergy, marca Biotek ${ }^{\circledR}$;

Microscópio óptico modelo Axioplan-2, equipado com filtro polarizador e acoplado à câmera digital Axiocan HRc com sistema de vídeo e aquisição automática de imagem, marca Carl Zeiss ${ }^{\circledR}$;

Placas de 96 poços, volume $200 \mu \mathrm{L}$, marca Fisher Sicentific ${ }^{\circledR}$;

Placas para Cromatografia em Camada Delgada (CCD), espessura de camada de 0,2 mm, marca Merck $^{\circledR}$; 


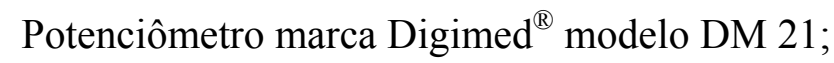

Sílica - gel cromatográfica, marca Merck ${ }^{\circledR}$;

Seringa de vidro $100 \mu \mathrm{m}$, marca Hamilton $^{\circledR}$;

Termobalança marca Shimadzu ${ }^{\circledR}$ modelo TGA-50

Unidade Filtrante HV em PE com membrana Durapore 0,45 $\mu \mathrm{m} 47 \mathrm{~mm}$, marca Millipore ${ }^{\circledR}$;

\# Vidraria volumétrica classe A;

* Viscosímetro marca Brookfield ${ }^{\circledR}$ modelo RVT;

Zetasizer Nano system ZS, marca Malvern ${ }^{\circledR}$. 


\subsection{MÉTODOS}

\subsubsection{Caracterização da matéria-prima}

\subsubsection{Espectrofotometria no Ultravioleta (UV)}

\subsection{Preparo da solução}

Transferiu-se 1,0 $\mathrm{mL}$ da amostra (ascorbato de monometilsilanotriol solução aquosa à 1\%) para um balão volumétrico de $25 \mathrm{~mL}$. O volume foi completado com solução de $\mathrm{H}_{2} \mathrm{SO}_{4}$ 0,1N. Dessa solução, transferiu-se uma alíquota de $1,0 \mathrm{~mL}$ para um balão volumétrico de $25 \mathrm{~mL}$, obtendo-se uma concentração final de $16 \mu \mathrm{g} / \mathrm{mL}$ de AMS.

\subsection{Condições empregadas no ensaio}

Velocidade de varredura: $350 \mathrm{~nm} / \mathrm{min}$;

Intervalo de varredura: $200-350 \mathrm{~nm}$;

Cubeta de Quartzo de $1 \mathrm{~cm}$;

Ordem do espectro: ordem zero;

Solvente testado: $\mathrm{H}_{2} \mathrm{SO}_{4} 0,1 \mathrm{~N}$.

\subsubsection{Espectrofotometria na região do infravermelho com transformada de Fourier (FTIR)}

As análises de espectroscopia na região do infravermelho (IV) foram realizadas em um espectrofotômetro Bomem com transformada de Fourier, modelo MB100, operando na região de 4000 a $400 \mathrm{~cm}^{-1}$ com resolução de $4 \mathrm{~cm}^{-1}$. As amostras foram analisadas utilizando-se celas para líquido, a técnica de pastilha de $\mathrm{KBr}$ e filmes depositados em cristais de $\mathrm{KBr}$, preparados por dispersão 


\subsubsection{Cromatografia em Camada Delgada (CCD)}

\subsection{Parâmetros estabelecidos para CCD}

Placas de vidro de sílica - gel cromatográfica;

Tamanho da placa: $20 \times 10 \mathrm{~cm}$;

Ativação da placa: $110^{\circ} \mathrm{C}$ por 10 minutos;

Saturação da cuba de vidro por 1 hora;

Revelador: solução de ninidrina.

\subsection{Preparo da solução padrão}

Para o ensaio de CCD foi preparada a seguinte solução padrão: $1 \mathrm{mg} / \mathrm{mL}$ de AMS (solução aquosa a 1\%) em solvente metanol.

\subsection{Sistema cromatográfico (fase móvel)}

A fase móvel selecionada para a análise por CCD é constituída de: $10 \%$ de etanol e $90 \%$ de ácido acético (v/v).

\subsection{Preparo de solução reveladora de ninidrina}

Pesou-se 0,3 g de ninidrina e dissolveu-se em $100 \mathrm{~mL}$ de n-butanol e $3 \mathrm{~mL}$ de ácido acético.

\subsection{Procedimento cromatográfico}

As análises foram realizadas em placas de sílica-gel cromatográfica $(10$ X $20 \mathrm{~cm})$. A solução padrão foi aplicada por meio de um capilar. Após a secagem das manchas, desenvolveu-se o cromatograma em um sistema solvente constituído de etanol $10 \%$ e ácido acético 90\%. Após secagem, com o auxílio da solução reveladora de ninidrina, os cromatogramas foram aquecidos até o aparecimento das manchas. Após o aparecimento das manchas o Rf foi determinado de acordo com a fórmula: 


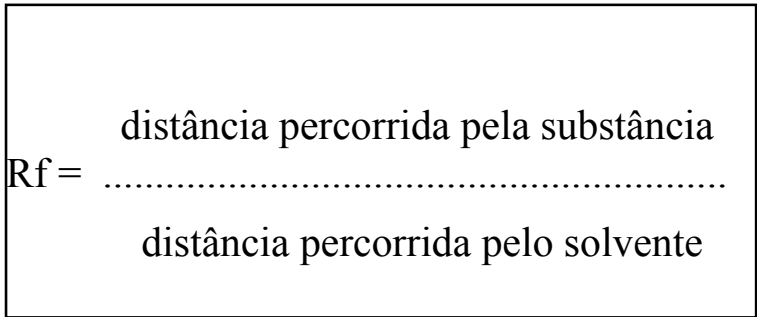

\subsubsection{Perda por dessecação}

Foi determinada com $1 \mathrm{~g}$ de AMS (solução aquosa a 1\%) analiticamente pesado. Tarou-se na balança uma cápsula de porcelana previamente dessecada por 30 minutos nas mesmas condições a serem empregadas na determinação. Introduziu-se a amostra na cápsula de porcelana, e pesou-se exatamente o seu conteúdo junto com a tampa. Por agitação lateral branda distribuiu-se a amostra o mais uniformemente possível. Colocou-se o recipiente de porcelana com a amostra na estufa removendo a tampa, mas deixando-a também na estufa, mantendo-se a amostra à $105^{\circ} \mathrm{C}$ por 4 horas. Ao abrir a estufa, fechouse a cápsula de porcelana imediatamente e deixou-se atingir a temperatura ambiente em dessecador antes da pesagem (USP, 2007).

\subsubsection{Análise Térmica}

\subsection{Caracterização via Termogravimetria (TG)/Termogravimetria Derivada (DTG)}

A caracterização termoanalítica com base nas técnicas de termogravimetria e termogravimetria derivada foi realizada em uma termobalança TGA-50 da marca Shimadzu ${ }^{\circledR}$. As medidas realizadas empregando cadinhos de platina com massa de amostra de $5,0 \mathrm{mg}$ sob atmosfera dinâmica de $\mathrm{N}_{2}(50 \mathrm{~mL} / \mathrm{min})$, com razão de aquecimento de 5 
${ }^{\circ} \mathrm{C} /$ min na faixa de temperatura de 25 à $200{ }^{\circ} \mathrm{C}$. Os resultados foram comparados com os obtidos pela análise de perda por dessecação.

\subsection{Caracterização via Calorimetria Exploratória Diferencial (DSC)}

\subsection{Ascorbato de monometilsilanotriol e as formulações F1 e F1A}

As curvas DSC do AMS e das formulações F1 e F1A foram obtidas em uma célula DSC-50 da marca Shimadzu utilizando cápsulas de alumínio parcialmente fechadas com aproximadamente $2 \mathrm{mg}$ de amostra sob atmosfera dinâmica de $\mathrm{N}_{2}(100 \mathrm{~mL} / \mathrm{min})$ e razão de aquecimento de $5{ }^{\circ} \mathrm{C} /$ min na faixa de temperatura de 25 à $150^{\circ} \mathrm{C}$.

\subsection{Formulações cosméticas F2, F2A, F3 e F3A}

As curvas DSC para as formulações F2, F2A, F3 e F3A foram obtidas em uma célula DSC-50 da marca Shimadzu utilizando cápsulas de alumínio parcialmente fechadas com aproximadamente $2 \mathrm{mg}$ de amostra sob atmosfera dinâmica de $\mathrm{N}_{2}(100 \mathrm{~mL} / \mathrm{min})$ e razão de aquecimento de $5{ }^{\circ} \mathrm{C} / \mathrm{min}$ na faixa de temperatura de 25 à $100^{\circ} \mathrm{C}$.

\subsection{Caracterização do AMS por DSC empregando a água destilada como} padrão

O AMS apresenta-se em solução aquosa a 1\%. Sendo assim, para avaliar o comportamento térmico desse princípio ativo por DSC, a água destilada foi empregada como padrão. Esses ensaios foram realizados em célula DSC-50 marca Shimadzu, empregando-se cápsulas de alumínio fechadas e nitrogênio líquido para resfriamento. Foram avaliados ciclos de resfriamento-aquecimento de: -5 à $-60{ }^{\circ} \mathrm{C} ; 10$ à $25{ }^{\circ} \mathrm{C} ;-5$ à -60 ${ }^{\circ} \mathrm{C}$ e 10 à $50{ }^{\circ} \mathrm{C}$. A quantidade de amostra foi de aproximadamente $10 \mathrm{mg}$ sob atmosfera dinâmica de atmosfera de $\mathrm{N}_{2}(100 \mathrm{~mL} / \mathrm{min})$ e razão de aquecimento de $5^{\circ} \mathrm{C} / \mathrm{min}$. 


\subsubsection{Análise do Tamanho de Partícula}

\subsection{Análise da distribuição de tamanho de partícula por difração a laser}

A análise da distribuição de tamanho de partícula por difração a laser foi realizada no equipamento Beckmann Coulter ${ }^{\circledR}$ modelo LS 13320 Laser Diffraction. A amostra de AMS (solução aquosa a 1\%) foi introduzida no aparelho por meio de uma pipeta automática para evitar a presença de bolha. As análises foram realizadas em triplicata. Medidas da média da distribuição do tamanho das partículas (D [4,3]), bem como mensurações do $\mathrm{D}[\mathrm{v}, 0.9], \mathrm{D}[\mathrm{v}, 0.5]$ e $\mathrm{D}[\mathrm{v}, 0.1]$, que representam respectivamente o diâmetro $(\mu \mathrm{m})$ no qual passam 90,50 e $10 \%$ das partículas.

\subsection{Análise da distribuição de tamanho de partícula por espalhamento dinâmico de luz}

A amostra de AMS (solução aquosa a 1\%) foi submetida sem diluições a medida de espalhamento dinâmico de luz utilizando-se o equipamento Zetasizer Nano system ZS, Malvern ${ }^{\circledR}$. A amostra foi introduzida em uma cela de quartzo de $1 \mathrm{~cm}$ de caminho óptico e as medições foram realizadas à temperatura ambiente de $25^{\circ} \mathrm{C}$. O equipamento possui um laser de He-Ne de $4 \mathrm{~mW}$ operando num comprimento de onda de $633 \mathrm{~nm}$ e realiza as medições não invasivas por "backscatter optics" (NIBS). As medições foram feitas num ângulo de detecção de $173^{\circ}$ e a posição da medição na cubeta foi automaticamente determinada pelo software do equipamento. O equipamento realiza em média 12 determinações para cada medida. Os diâmetros internos das partículas foram obtidos com base nas medidas, bem como a distribuição, representada pelo índice de polidispersividade (PDI). 


\subsubsection{Viscosidade}

A análise da viscosidade aparente das emulsões cosméticas foi realizada empregando-se um viscosímetro marca Brookfield ${ }^{\circledR}$ modelo RVT, a unidade utilizada para análise foi centiPoise (cP), comumente utilizada para medidas de viscsidade. As leituras foram realizadas periodicamente nos tempos T0, T1, 17, T15, T30, T60 e T90 dias após a obtenção das formulações.

\subsubsection{Avaliação do potencial Antioxidante in vitro do AMS}

\subsubsection{Determinação da atividade antioxidante pela reação com DPPH ( 2,2'́-difenil- 1-picrilhidrazil )}

A capacidade da atividade antioxidante do AMS, foi avaliada com base na sua reação com o radical DPPH ( 2,2' -difenil-1-picrilhidrazil ). Para avaliação, primeiramente foram preparadas 5 diferentes diluições de $\operatorname{AMS}(7,5 ; 15 ; 50 ; 90 ; 120$ e $150 \mu \mathrm{g} / \mathrm{mL})$ em $10 \mathrm{~mL}$ de metanol. Transferiu-se $1,0 \mathrm{~mL}$ de cada diluição para um tubo de ensaio e adicionou-se 3,0 mL de solução de $\mathrm{DPPH}$ em cada tubo. O tubo branco também foi preparado para comparação. O ácido ascórbico foi empregado como padrão. A reação ocorreu à temperatura ambiente de $25^{\circ} \mathrm{C}$ por 2 horas, em ausência de luz. Após a reação, procedeu-se a leitura em $517 \mathrm{~nm}$ utilizando um espectrofotômetro. Posteriormente foram realizados os cálculos para o valor da medida da capacidade antioxidante do AMS.

O valor da medida da capacidade antioxidante da substância em teste foi dado em função do ácido ascórbico, que é uma substância com propriedade antioxidante consagrada. $\mathrm{O}$ valor que designaria essa capacidade pode ser dado apenas pela proporção das absorbâncias medidas entre a amostra e o controle (BRAND-WILLIAMS et al, 1995):

$$
\text { \% redução DPPH= }[(\mathrm{ABS} \text { controle }-\mathrm{ABS} \text { amostra }) / \mathrm{ABS} \text { controle }] \times 100
$$




\subsubsection{Determinação do potencial antioxidante por fluorescência - ORAC (Oxigen Radical Absorbance Capacity Assay)}

\subsection{Preparo das amostras}

O AMS (solução aquosa à 1\%) foi diluído em tampão fosfato $75 \mathrm{mM}(\mathrm{pH} 7,0)$ para as análises.

\subsection{Branco}

Adicionou-se $200 \mu \mathrm{L}$ de tampão fosfato $75 \mathrm{mM}$ (pH 7,0) nos 5 poços. Foi montado um isolamento para manutenção da temperatura ao redor dos poços com adição de $300 \mathrm{~mL}$ de água nos poços ao redor dos utilizados no ensaio.

\subsection{Controle}

Adicionou-se $25 \mu \mathrm{L}$ de tampão fosfato $75 \mathrm{mM}(\mathrm{pH} 7,0)$ nos 5 poços.

\subsection{Amostra $\left(\operatorname{Trolox}^{\circledR}\right)$}

Em cada poço foi adicionado para cada concentração $(100,50,25,12,5,6,25 \mu \mathrm{M})$ : $25 \mu \mathrm{L}$ de padrão $\left(\right.$ Trolox $^{\circledR}$ ) e $150 \mu \mathrm{L}$ de fluoresceína. A placa foi incubada à $37^{\circ} \mathrm{C}$, por 30 minutos e foi acrescentado nos poços de controle e padrão, iniciando pelo último : $25 \mu \mathrm{L}$ de AAPH (2,2`- azobis (2-amidinopropane) dihydrochloride. Após a adição de AAPH, agitou-se por 10 segundos com intensidade máxima e a leitura foi realizada a cada 1 minuto, por 1 hora.

\subsection{Cálculo}

O valor final foi calculado com base na equação de regressão linear entre a concentração de $\operatorname{Trolox}^{\circledR}$ e a área sob a curva de decaimento de fluorescência (AUC). Os resultados são expressos em $\mu \mathrm{M}$ equivalentes de $\operatorname{Trolox}^{\circledR} / \mathrm{g}$ da amostra. Sendo o cálculo baseado na seguinte fórmula: 


$$
\begin{aligned}
& \text { (AUC amostra - AUC branco) } \quad \text { molaridade Trolox }{ }^{\circledR} \\
& \text { X } \\
& \text { (AUC trolox }{ }^{\circledR}-\text { AUC branco) concentração amostra }
\end{aligned}
$$

\subsubsection{Obtenção das formulações}

\section{F1 e F1A}

A composição das emulsões F1 e F1A (Tabela 4) é a mesma, diferenciando-se apenas pela adição de 10\% de AMS (solução aquosa a 1\%) à emulsão F1A. A adição de AMS (solução aquosa a 1\%) na emulsão F1A foi realizada para avaliação do comportamento do AMS na emulsão quando comparado a emulsão com a mesma composição, no entanto sem a presença de AMS.

As formulações F1 e F1A foram obtidas mediante a pesagem dos componentes da formulação e agitação contínua à temperatura ambiente. $\mathrm{O}$ método é conhecido como método de emulsificação à frio. As formulações forma armazenadas em potes de vidro.

\section{F2 e F2 A}

A composição das emulsões F2 e F2A (Tabela 5) é a mesma, diferenciandose apenas na adição de $10 \%$ de AMS (solução aquosa a 1\%) à emulsão F2A. A adição de AMS (solução aquosa a 1\%) na emulsão F2A foi realizada para avaliação do comportamento do AMS na emulsão quando comparado a emulsão com a mesma composição, no entanto sem a presença de AMS.

A formulações F2 e F2A foram obtidas por pesagem dos componentes e posterior aquecimento à $75^{\circ} \mathrm{C}$, das fases aquosa e oleosa, separadamente. A fase aquosa foi vertida pela fase oleosa e a emulsão foi agitada manualmente até o resfriamento. Após 
as emulsões atingirem $25^{\circ} \mathrm{C}$, os componentes da fase fria foram adicionados. O método é conhecido como método de emulsificação por inversão de fases. As formulações foram armazenadas em potes de vidro.

\section{F3 e F3 A}

A composição das emulsões F3 e F3A (Tabela 6) é a mesma, diferenciandose apenas na adição de $10 \%$ de AMS (solução aquosa a 1\%) à emulsão F3A. A adição de AMS (solução aquosa a 1\%) na emulsão F3A foi realizada para avaliação do comportamento do AMS na emulsão quando comparado a emulsão com a mesma composição, no entanto sem a presença de AMS.

As formulações F3 e F3A foram obtidas por pesagem dos componentes e posterior aquecimento à $75^{\circ} \mathrm{C}$, das fases aquosa e oleosa, separadamente. A fase aquosa foi vertida pela fase oleosa e a emulsão foi agitada manualmente até o resfriamento. Após as emulsões atingirem a temperatura de $25^{\circ} \mathrm{C}$, os componentes da fase fria foram adicionados. O método é conhecido como método de emulsificação por inversão de fases. As formulações foram armazenadas em potes de vidro.

\subsubsection{Teste de estabilidade preliminar}

Foram pesadas alíquotas de 5,0 gramas das formulações e acondicionadas em tubo graduado para centrífuga. As amostras foram centrifugadas (Centrífuga Excelsa ${ }^{\circledR}$ modelo $206 \mathrm{MP}$ ), em ciclos de 30 minutos na velocidade de $3000 \mathrm{rpm}$ à temperatura de 25 ${ }^{\circ} \mathrm{C}$. 


\subsubsection{Determinação do tipo de emulsão}

Para avaliação do tipo de emulsão foi utilizado o teste de diluição (SANTOS et al, 2006) que consiste na determinação da solubilidade da fase externa da emulsão em dois solventes: água e óleo mineral. Para isso, pesou-se 1,0 g das formulações em um tubo de ensaio, adicionando em seguida 9,0 gramas do solvente. Homogeneizou-se com o auxílio de um vórtex, mantendo em repouso por 5 minutos após agitação. Empregou-se a seguinte classificação:

a) Emulsão $\mathrm{A} / \mathrm{O}=$ solúvel em óleo mineral, formação de fase homogênea e sem grumos;

b) Emulsão $\mathrm{O} / \mathrm{A}=$ solúvel em água, formação de fase homogênea e sem grumos.

\subsubsection{Condições de armazenamento para o teste de estabilidade acelerada}

Foram obtidas 500 gramas de cada fórmula, divididas nas seguintes embalagens e formas de armazenamento (BRASIL, 2004).

Potes de poliestireno branco em estufa a $45^{\circ} \mathrm{C}$;

Embalagem de vidro incolor para geladeira $\left(5{ }^{\circ} \mathrm{C}\right)$; temperatura de $25{ }^{\circ} \mathrm{C}$ e fotoestabilidade de $25^{\circ} \mathrm{C}$. Durante o envase não foi completado o volume total da embalagem permitindo um espaço vazio (headspace) de aproximadamente um terço da capacidade do frasco para possíveis trocas gasosas.

\subsubsection{Avaliação das formulações}

As formulações foram submetidas às seguintes condições de estresse térmico: $45^{\circ}$ $\mathrm{C}$ em estufa, $25^{\circ} \mathrm{C}$ em câmera de fotoestabilidade, temperatura de $25^{\circ} \mathrm{C}$ e $5{ }^{\circ} \mathrm{C}$ em geladeira. As avaliações foram realizadas nos tempos: zero (T0); um (T1); sete (T7); 
quinze (T15); trinta (T30); sessenta (T60), noventa (T90), quanto ao aspecto, cor, odor, pH e viscosidade aparente (BRASIL, 2004). Os resultados foram compilados sob a forma de tabela.

É válido relatar que, para análise de $\mathrm{pH}$, pesou-se $1 \mathrm{~g}$ de cada formulação em tubo de ensaio, acrescentando-se $9 \mathrm{~mL}$ de água destilada. Após dispersão da mistura, o pH foi mensurado à temperatura ambiente.

Para os testes de estabilidade preliminar e acelerada, a seguinte nomenclatura foi empregada para classificar as formulações quanto ao aspecto, cor e odor:

$\mathbf{N}=$ Normal, sem alteração; $\mathbf{L M}=$ Levemente Modificado; $\mathbf{M}=$ Modificado e $\mathbf{I M}=$ Intensamente Modificado.

\subsubsection{Avaliação das formulações cosméticas}

\subsubsection{Análise de Tamanho de Partícula por Difração a Laser (ATP-DL)}

O procedimento de ATP-DL foi o mesmo para as formulações: F1 e F1A, F2 e F2A e F3 e F3A. As amostras foram diluídas 100 X ( 0,08 g de cada formulação foi diluída em 7,2 mL de água destilada) para adequação da análise. Agitou-se a mistura no vórtex. Cada amostra foi introduzida no aparelho Beckmann Coulter ${ }^{\circledR}$ modelo LS 13320 Laser Diffraction com auxílio de uma pipeta automática para evitar a presença de bolhas. É válido salientar que a o fator de diluição não afetou os resultados obtidos. Medidas da média da distribuição do tamanho das partículas (D [4,3]), bem como mensurações do D $[\mathrm{v}, 0.9], \mathrm{D}[\mathrm{v}, 0.5]$ e $\mathrm{D}[\mathrm{v}, 0.1]$, que representam respectivamente o diâmetro $(\mu \mathrm{m})$ no qual passam $90 \%, 50 \%$ e $10 \%$ das partículas foram realizadas. 


\subsubsection{Análise microscópica das formulações}

O procedimento de análise microscópica das formulações foi o mesmo para as formulações: F1 e F1A, F2 e F2A e F3 e F3A. Uma pequena quantidade das formulações foi colocada sobre uma lâmina de vidro, cobrindo-a com uma lamínula, e em seguida submetida à análise microscópica (Microscópio óptico modelo Axioplan-2, Carl Zeiss $^{\circledR}$ ). Foi avaliada a homogeneidade da dispersão e, com o auxílio de polarização, observada a presença de áreas de anisotropia, indicativa de cristais líquidos. As análises foram realizadas a de $25^{\circ} \mathrm{C}$.

\subsubsection{Método cromatográfico}

\subsubsection{Parâmetros estabelecidos}

No desenvolvimento, foram testadas diferentes fases móveis com diferentes concentrações do pareador iônico. Sendo assim, as condições e fase móvel selecionadas para validação do método consistem em:

Coluna Synergi-Hydro ${ }^{\circledR}$ RP Phenomenex 150 X 4,6 mm, partícula de $4 \mu, 80 \AA ̊$ de poro, C18;

Equipamento: Cromatógrafo Líquido Shimadzu ${ }^{\circledR}$ LC-10 AD VC com detector UV-VIS, sistema controlador SLC-10 ${ }^{a}$ VP, injeção automática e sistema desgaseificador DGU-14, acoplado ao software Class VP ${ }^{\circledR}$;

Modo: Fase Reversa, com pareamento iônico;

Fase Móvel: TBA 30mM + metanol:água $(30: 70$ v/v) $(\mathrm{pH}=5,94)$;

Fluxo de trabalho: $1 \mathrm{~mL} / \mathrm{min}$;

Injeção: manual;

Tempo de corrida: 10 minutos; 
Detecção: UV a 254 nm;

Temperatura: ambiente $\left(25^{\circ} \mathrm{C}\right)$.

\subsubsection{Validação do Método}

A validação do método foi conduzida experimentalmente de acordo com as recomendações da ICH (International Conference on Harmonization), instrumento Q2(R1) -Validation of analytical procedures:text and methodology (novembro, 2005) e da USP 30.

\subsection{Preparo da fase móvel}

As fases móveis testadas foram preparadas diariamente em balão volumétrico por dissolução do aditivo brometo de tetrabutilamônio (TBA) em água purificada Milli $\mathrm{Q}^{\circledR}$. A proporção de solvente orgânico foi mensurada e adicionada posteriormente. O volume final foi filtrado à vácuo em membrana filtrante de $0,45 \mu \mathrm{m}$. Procedeu-se a desgaseificação do sistema em aparelho de ultra-som por 15 minutos.

\subsection{Construção da curva analítica}

Para o preparo da solução padrão, foram pesados analiticamente, 50 g de AMS e transferidos para um balão volumétrico de $10 \mathrm{~mL}$ e o volume foi completado com fase móvel. Uma alíquota de $0,5 \mathrm{~mL}$ dessa solução foi transferida para um balão volumétrico de $10 \mathrm{~mL}$, medidos volumetricamente e o volume foi completado com fase móvel, obtendo-se uma concentração final de $25 \mu \mathrm{g} / \mathrm{mL}$ de AMS.

Para obtenção da curva analítica do AMS, foram injetadas no sistema cromatográfico após filtração em seringa de vidro acoplada a unidade filtrante de $0,45 \mu \mathrm{m}$, quantidades crescentes de solução padrão de $\operatorname{AMS}(10,20,40,80,160 \mu \mathrm{L})$, a fim de obter a curva analítica. As análises foram realizadas em triplicata. 
A linearidade foi obtida com base na curva analítica. A curva foi analisada pelo método dos mínimos quadrados, observando-se que cada uma das retas passa muito próximo da origem, uma vez que o valor da intersecção da reta (a), analisado pelo teste t, é insignificante, indicando que o método empregado não está sujeito a erros determinados (BARROS, SCARMINO \& BRUNS, 2003).

\subsection{Especificidade}

\section{Pesquisa de interferentes}

Foram pesados, analiticamente, em um balão volumétrico de $10 \mathrm{~mL}, 1,5 \mathrm{~g}$ de cada formulação desenvolvida sem adição de AMS (especificadas no item 4.2.4). O volume do balão foi completado com fase móvel. A solução foi agitada em um agitador vórtex. Transferiu-se um alíquota de $3 \mathrm{~mL}$ para um balão volumétrico de $10 \mathrm{~mL}$ e o volume foi completado com fase móvel, obtendo-se uma concentração final correspondente a $45 \mu \mathrm{g} / \mathrm{mL}$ de AMS. A solução foi agitada em um agitador vórtex. Após esse procedimento a solução foi transferida para tubo graduado para centrífuga. As amostras foram centrifugadas (Centrífuga Eppendorf ${ }^{\circledR}$ modelo: $5804 \mathrm{R}$ ) em ciclos de 15 minutos na velocidade de $15000 \mathrm{rpm}$ à temperatura ambiente $\left(25^{\circ} \mathrm{C}\right)$. A fração solúvel foi coletada em tubos Eppendorf novos. Antes de iniciar as injeções no cromatógrafo, cada solução foi filtrada em unidades filtrantes de $0,45 \mu \mathrm{m}$. As análises foram realizadas em triplicata. 


\subsection{Quantificação do teor de AMS nas formulações cosméticas obtidas}

\section{Preparação da solução amostra}

Foram pesados analiticamente em um balão volumétrico de $10 \mathrm{~mL}, 1,5 \mathrm{~g}$ de cada formulação desenvolvida contendo $10 \%$ de AMS (especificadas no item 4.2.4). O volume do balão foi completado com a fase móvel. A solução foi agitada em um agitador vórtex. Transferiu-se um alíquota de $3 \mathrm{~mL}$ para um balão volumétrico de $10 \mathrm{~mL}$ e o volume foi completado com fase móvel, obtendo-se uma concentração final de $45 \mu \mathrm{g} / \mathrm{mL}$ de AMS. A solução foi agitada em um agitador vórtex. Após esse procedimento a solução foi transferida para tubo graduado para centrífuga. As amostras foram centrifugadas (Centrífuga Eppendorf ${ }^{\circledR}$ modelo: $5804 \mathrm{R}$ ) em ciclos de 15 minutos na velocidade de 15000 rpm à temperatura de $25^{\circ} \mathrm{C}$. A fração solúvel foi coletada em tubos eppendorf novos. Antes de iniciar as injeções no cromatógrafo, cada solução foi filtrada em unidades filtrantes de $0,45 \mu \mathrm{m}$. Foram obtidas 6 replicatas correspondendo a concentração de 45 $\mu \mathrm{g} / \mathrm{mL}$ de AMS. O teor de AMS foi calculado em função da equação da curva de calibração.

\subsection{Exatidão (Recuperação)}

\section{Preparação da solução padrão}

Foram pesados, analiticamente, 25 mg de AMS (solução aquosa à 1\%) em um balão volumétrico de $25 \mathrm{~mL}$. O volume foi completado com fase móvel. Obteve-se uma concentração final de $1000 \mu \mathrm{g} / \mathrm{mL}$ de AMS. 


\section{Preparação da solução amostra}

Foram pesados, analiticamente, $0,1 \mathrm{~g}$ de cada formulação contendo $10 \%$ de AMS (especificadas no item 4.2.4) em um balão volumétrico de $25 \mathrm{~mL}$. O volume foi completado com fase móvel. Obteve-se uma concentração final de $1000 \mu \mathrm{g} / \mathrm{mL}$ de AMS. A solução foi agitada em um agitador vórtex. Após esse procedimento a solução foi transferida para tubo graduado para centrífuga. As amostras foram centrifugadas (Centrífuga Eppendorf ${ }^{\circledR}$ modelo: $5804 \mathrm{R}$ ) em ciclos de 15 minutos na velocidade de 15000 rpm à temperatura de $25^{\circ} \mathrm{C}$. A fração solúvel foi coletada em tubos Eppendorf novos.

Alíquotas das soluções padrão e amostra foram transferidas para balões volumétricos de $10 \mathrm{~mL}$ completando-se o volume com fase móvel, conforme tabela 7 :

Tabela 5. Esquema das alíquotas das soluções padrão e amostra obtidas para o ensaio da exatidão.

\begin{tabular}{lcc}
\hline Balão & $\begin{array}{c}\text { Solução padrão } \\
\mathbf{1 0 0 0} \mathbf{\mu g} / \mathbf{m L} \text { de AMS } \\
\text { volume }(\mathbf{m L})\end{array}$ & $\begin{array}{c}\mathbf{1 0 0 0} \boldsymbol{\mu g} / \mathbf{m L} \mathbf{~ d e ~ A M S ~} \\
\text { volume (mL) }\end{array}$ \\
\hline 1 & 1,0 & ------- \\
\hline 2 & ------- & 1,0 \\
\hline 3 & 1,0 & 1,0 \\
\hline 4 & 2,0 & 1,0 \\
\hline 5 & 3,0 & 1,0
\end{tabular}

A porcentagem de recuperação $(\% \mathrm{R})$ para cada amostra foi calculada de acordo com a seguinte equação: 


$$
\begin{aligned}
& \% \mathrm{R}=\mathrm{C} p-\mathrm{C} a \quad \mathrm{X} 100 \\
& \mathrm{P} a d
\end{aligned}
$$

Onde: $\mathrm{C} p$ é a concentração da amostra adicionada de padrão

C $a$ é a concetração da amostra sem padrão

$\mathrm{P}$ ad é a concentração de padrão adicionada na amostra

\subsection{Determinação dos limites de detecção e quantificação}

Os limites de detecção (LD) e de quantificação (LQ) foram determinados com base no desvio padrão da resposta instrumental (desvio padrão do residual da linha de regressão) e sua relação com a inclinação da reta na curva padrão construída a baixas concentrações (SWARTZ et al, 1998).

O cálculo para o LD e LD foi realizado segundo as seguintes fórmulas (SWARTZ \& KRULL, 1998):

$$
\begin{aligned}
& \mathrm{LD}=\quad \text { Desvio padrão médio } \quad \text { x } 3 \\
& \text { Inclinação da curva de calibração }
\end{aligned}
$$

$$
\begin{aligned}
& \mathrm{LQ}=\quad \text { Desvio padrão médio } \quad \mathrm{x} 10 \\
& \text { Inclinação da curva de calibração }
\end{aligned}
$$




\subsection{Estabilidade das soluções padrão}

A amostra padrão de ascorbato de monometilsilanotriol (solução aquosa à 1\%) foi congelada e, ao sofrer descongelamento foi analisada 24, 48 e 72 horas após atingir temperatura ambiente. 


\section{RESULTADOS}

\subsection{Caracterização da matéria-prima}

\subsubsection{Espectro no ultravioleta}

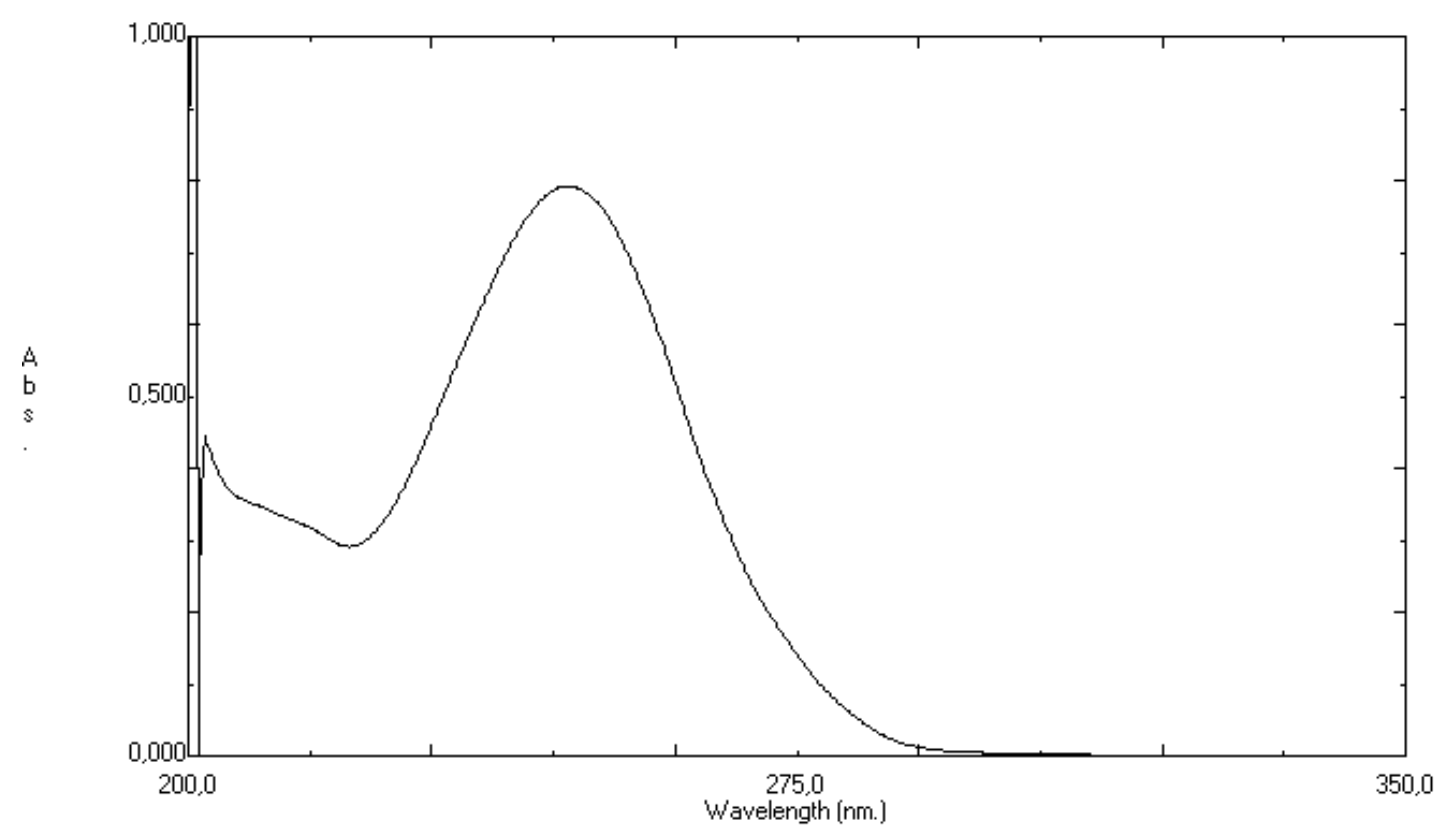

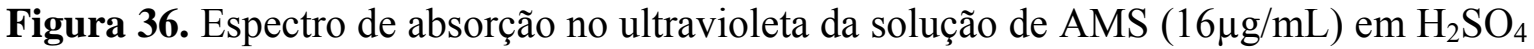
$0,1 \mathrm{~N}$, pico máximo em $247 \mathrm{~nm}$. 


\subsubsection{Espectro no infravermelho}

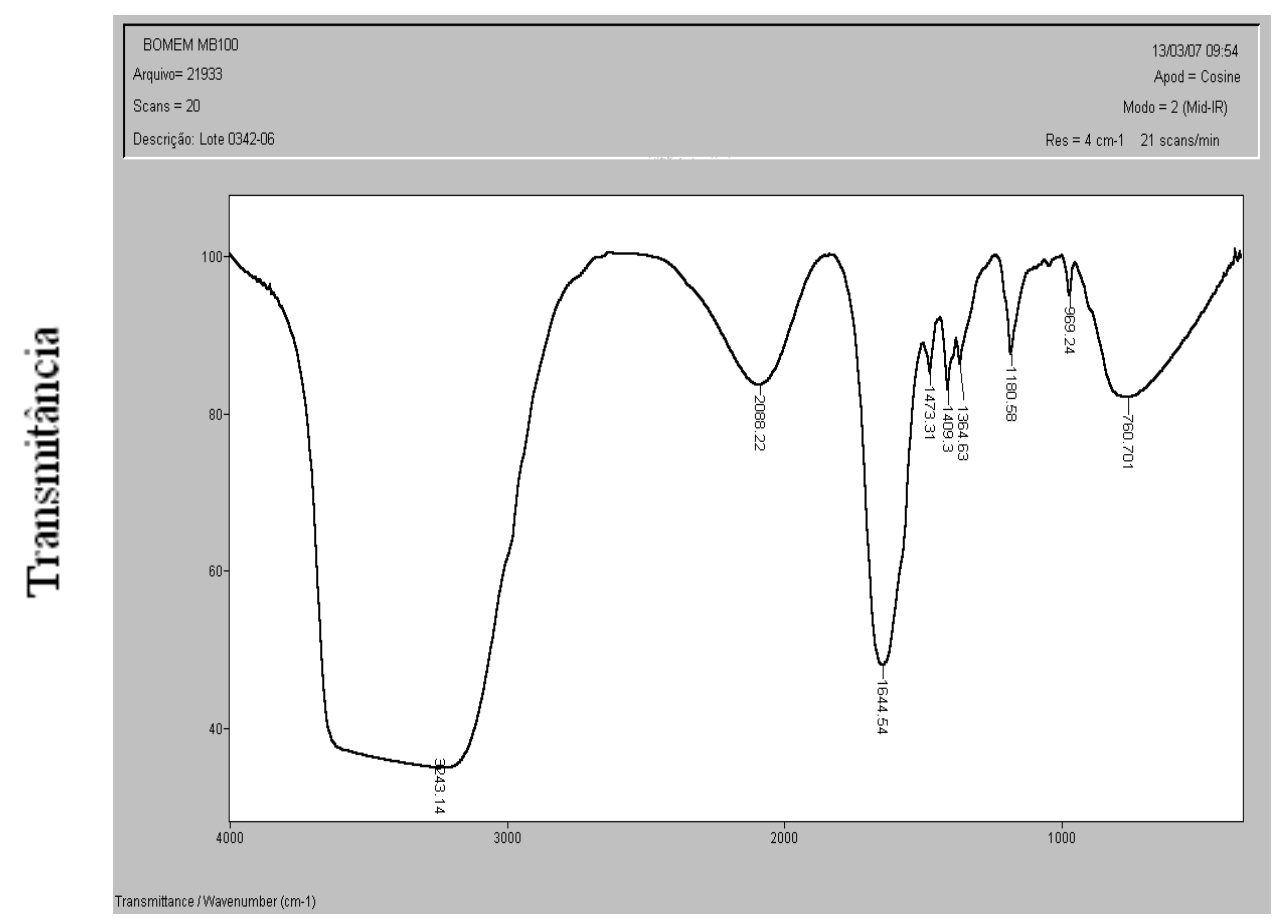

\section{Comprimento de onda $\left(\mathrm{cm}^{-1}\right)$}

Figura 37. Espectro de absorção na região do infravermelho do AMS em filme sobre placa de $\mathrm{KBr}$.

Tabela 6. Bandas de absorção obtidas na determinação do espectro no infravermelho do AMS em filme sob placa de $\mathrm{KBr}$.

\begin{tabular}{ll}
\hline Comprimento de onda $\mathbf{~ c m}^{-1}$ & Banda de absorção \\
\hline 3243,14 & $v,-\mathrm{OH}$ \\
1644,54 & $\mathrm{C}=\mathrm{O}$ \\
1160,58 & $v, \mathrm{Si}-\mathrm{OH}$ \\
760,70 & $\delta,-\mathrm{OH}$ \\
\hline
\end{tabular}




\subsubsection{Cromatografia em camada delgada}

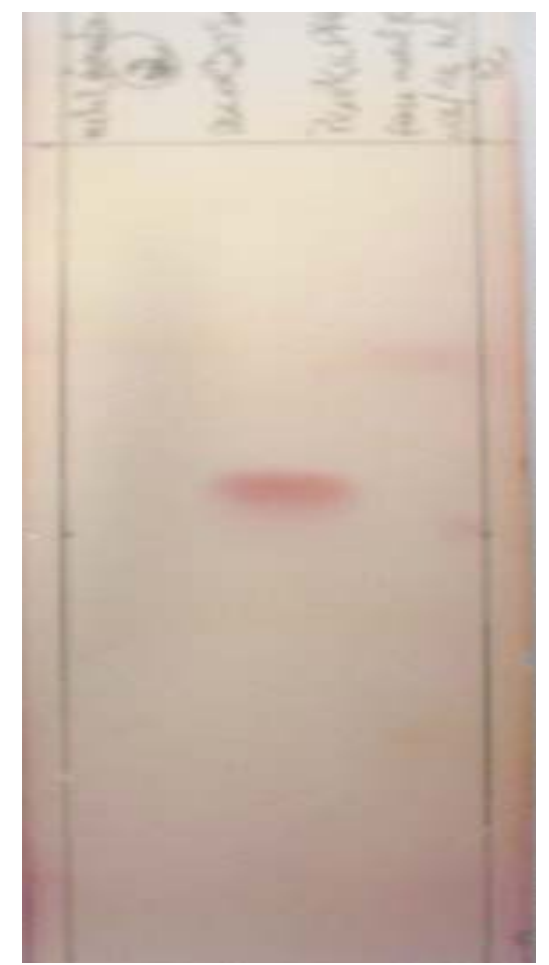

Figura 38. Placa cromatográfica de identificação do AMS. Fase móvel: etanol 10\% e ácido acético $90 \%$, fase estacionária sílica gel $60 \mathrm{Merck}^{\circledR}$, utilizando ninidrina como revelador, Rf 0,58 .

\subsubsection{Perda por dessecação}

O resultado obtido na determinação da perda por dessecação foi de $98,2 \%$ e oresíduo foi de $1,8 \%$. 


\subsubsection{Análise Térmica}

As figuras a seguir caracterizam o comportamento térmico dos AMS nas condições estudadas.

\subsubsection{Termogravimetria (TG) /Termogravimetria Derivada (DTG)}

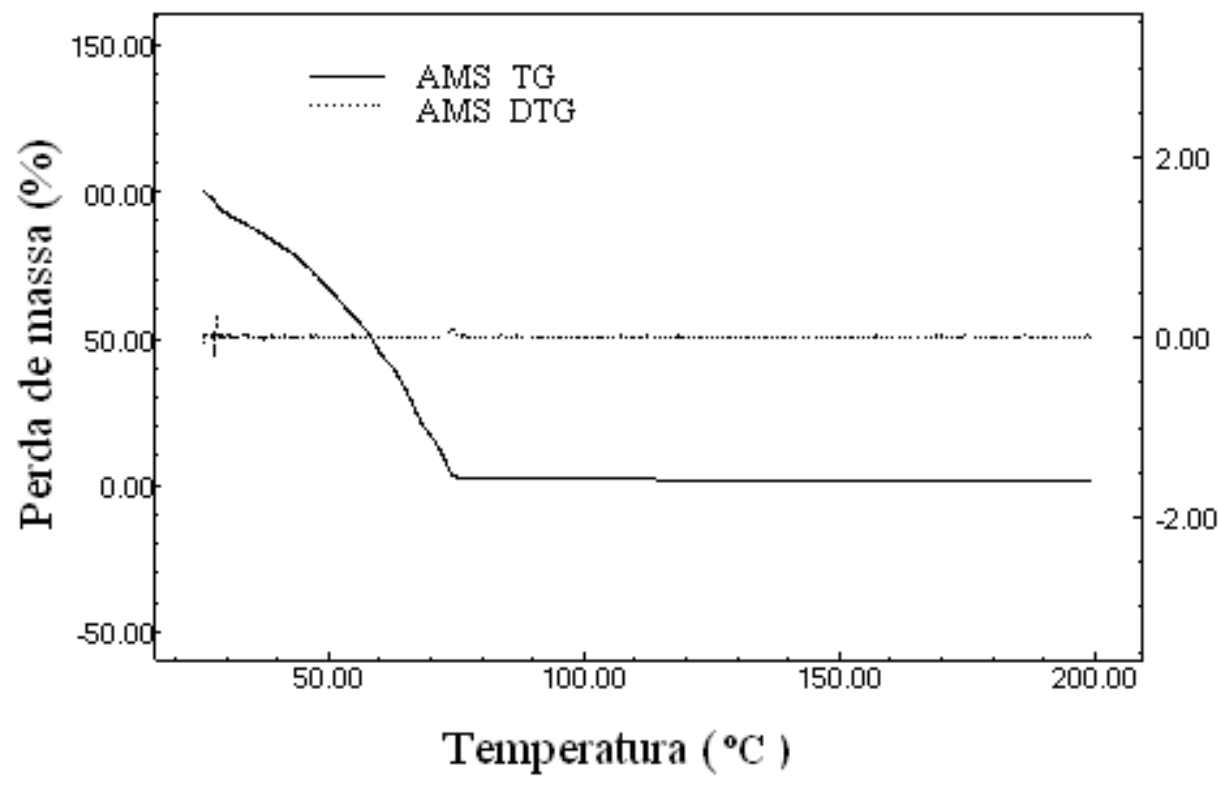

Figura 39. Curvas TG/DTG do AMS obtidas nas seguintes condições: razão de aquecimento $5{ }^{\circ} \mathrm{C} / \mathrm{min}, 25$ à $150{ }^{\circ} \mathrm{C}$, massa da amostra de $5,0 \mathrm{mg}$ sob atmosfera dinâmica de $\mathrm{N}_{2}(50 \mathrm{~mL} / \mathrm{min})$. 


\subsubsection{Caracterização via Calorimetria Exploratória Diferencial (DSC)}

\subsection{Curva DSC do AMS}

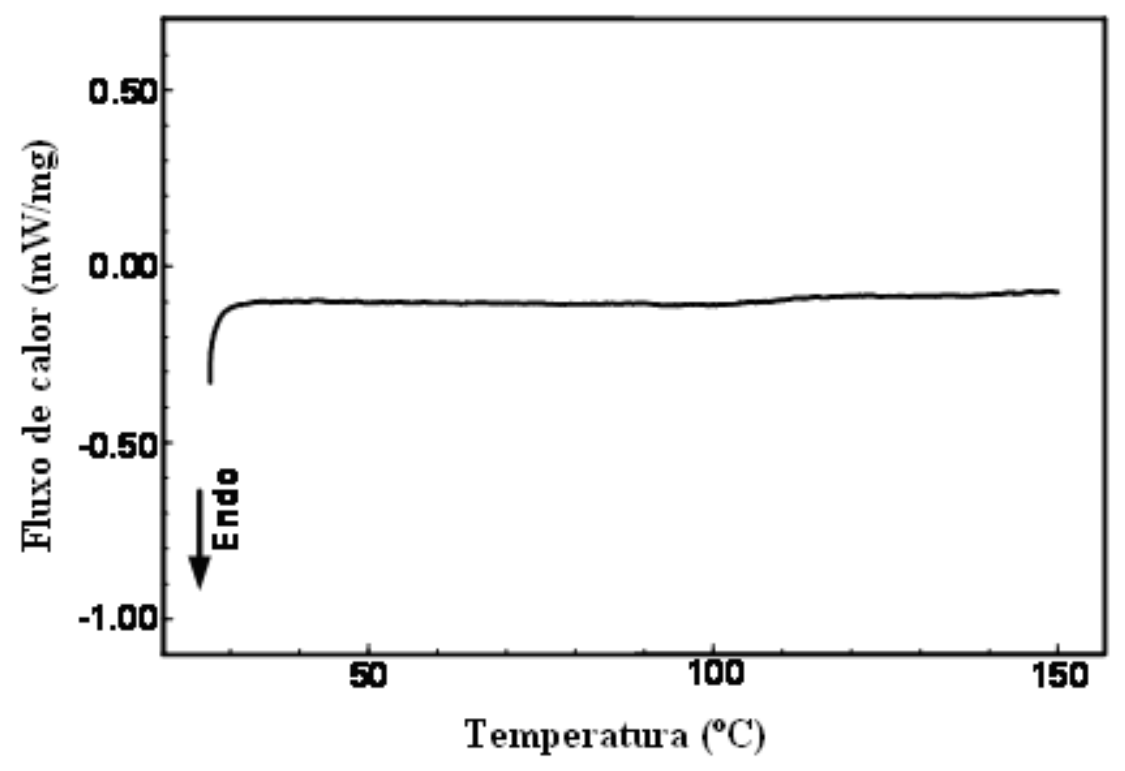

Figura 40. Curva DSC do AMS obtida nas seguintes condições: razão de aquecimento 5 ${ }^{\circ} \mathrm{C} / \mathrm{min}, 25$ à $150{ }^{\circ} \mathrm{C}$, massa da amostra de $2,0 \mathrm{mg}$ sob atmosfera dinâmica de $\mathrm{N}_{2}(100$ $\mathrm{mL} / \mathrm{min})$. 


\subsection{Curva DSC das formulações F1 e F1A}

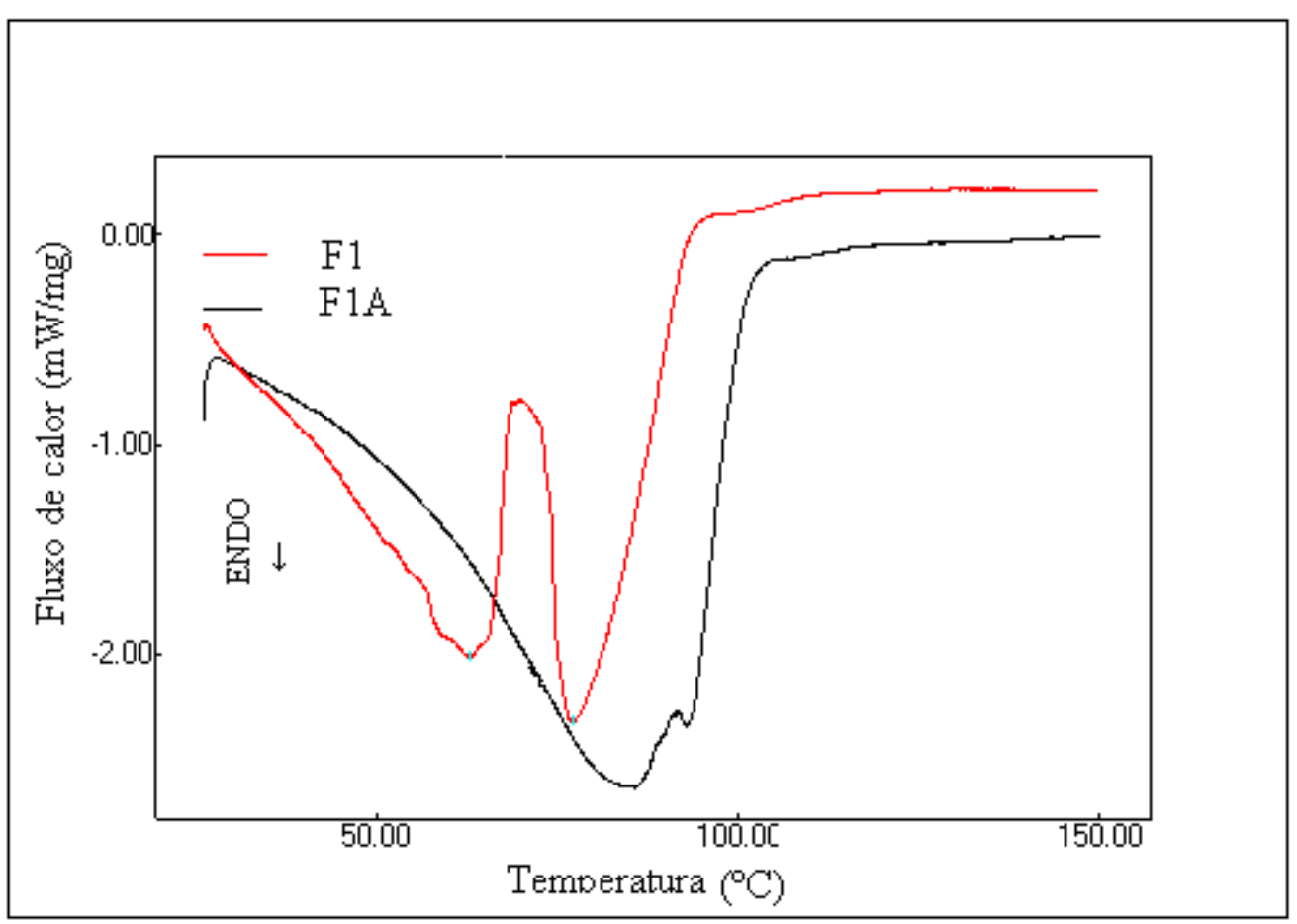

Figura 41. Curvas DSC das formulações F1 e F1A obtidas nas seguintes condições: razão de aquecimento $5{ }^{\circ} \mathrm{C} / \mathrm{min}$, 25 à $150{ }^{\circ} \mathrm{C}$, massa das amostras de 2,0 mg sob atmosfera dinâmica de $\mathrm{N}_{2}(100 \mathrm{~mL} / \mathrm{min})$. 


\subsection{Curva DSC das formulações F2 e F2A}

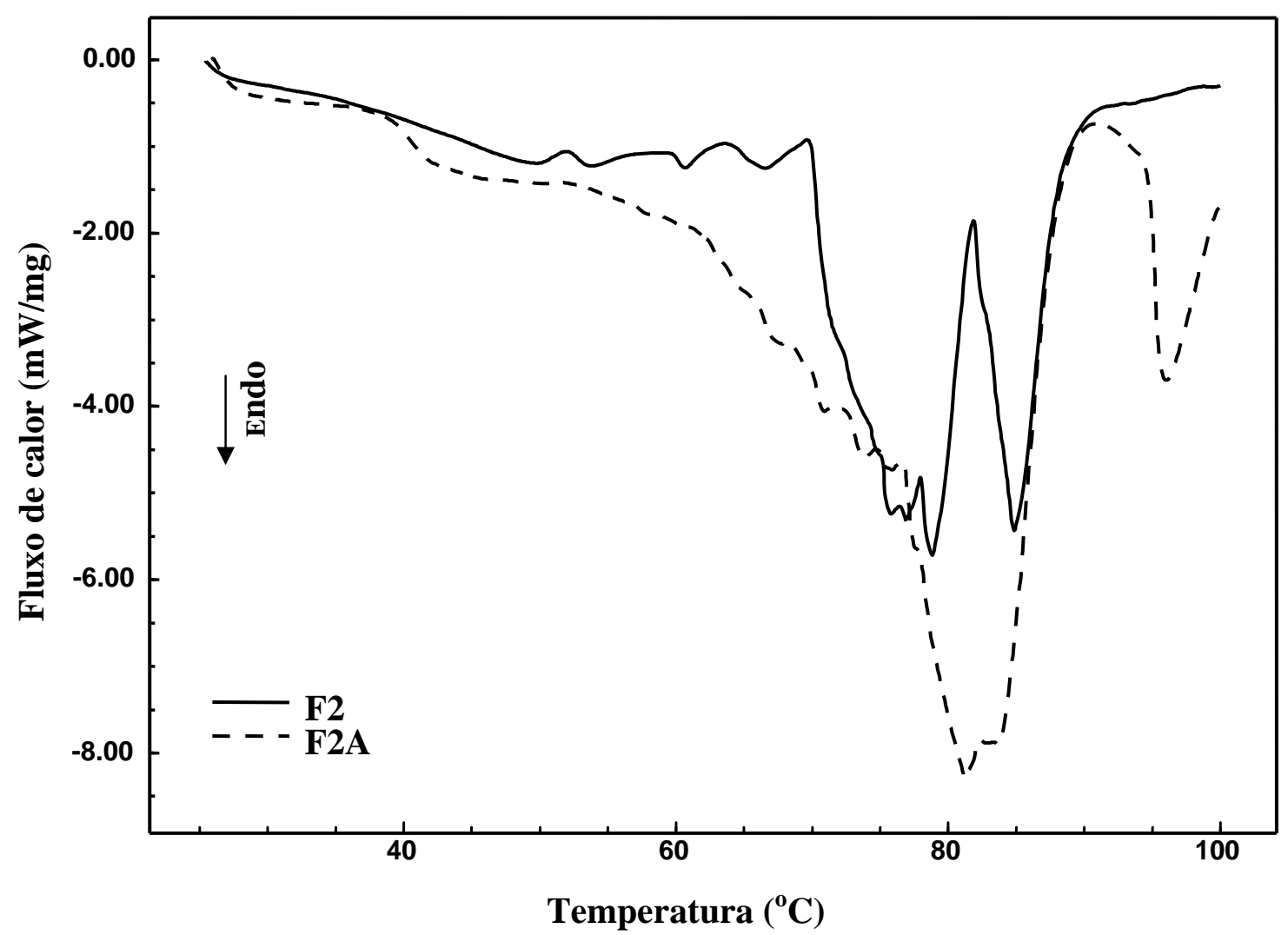

Figura 42. Curvas DSC das formulações F2 e F2A obtidas nas seguintes condições: razão de aquecimento $5{ }^{\circ} \mathrm{C} / \mathrm{min}$, 25 à $100{ }^{\circ} \mathrm{C}$, massa das amostras de $2,0 \mathrm{mg}$ sob atmosfera dinâmica de $\mathrm{N}_{2}(100 \mathrm{~mL} / \mathrm{min})$. 


\subsection{Curva DSC das formulações F3 e F3A}

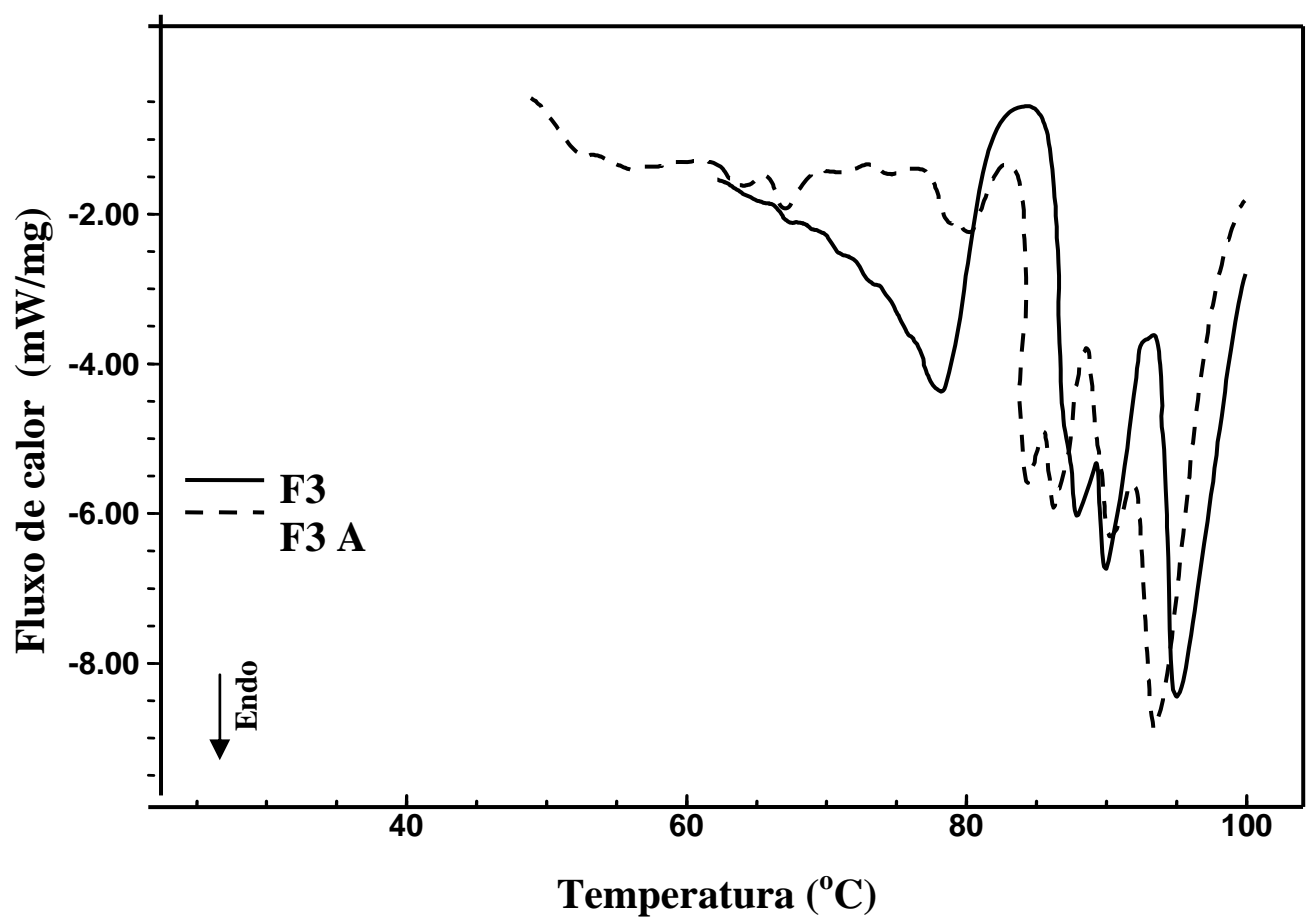

Figura 43. Curvas DSC das formulações F3 e F3A obtidas nas seguintes condições: razão de aquecimento $5{ }^{\circ} \mathrm{C} / \mathrm{min}$, 25 à $100{ }^{\circ} \mathrm{C}$, massa das amostras de 2,0 mg sob atmosfera dinâmica de $\mathrm{N}_{2}(100 \mathrm{~mL} / \mathrm{min})$. 


\subsection{Caracterização do AMS por DSC empregando a água destilada como}

padrão

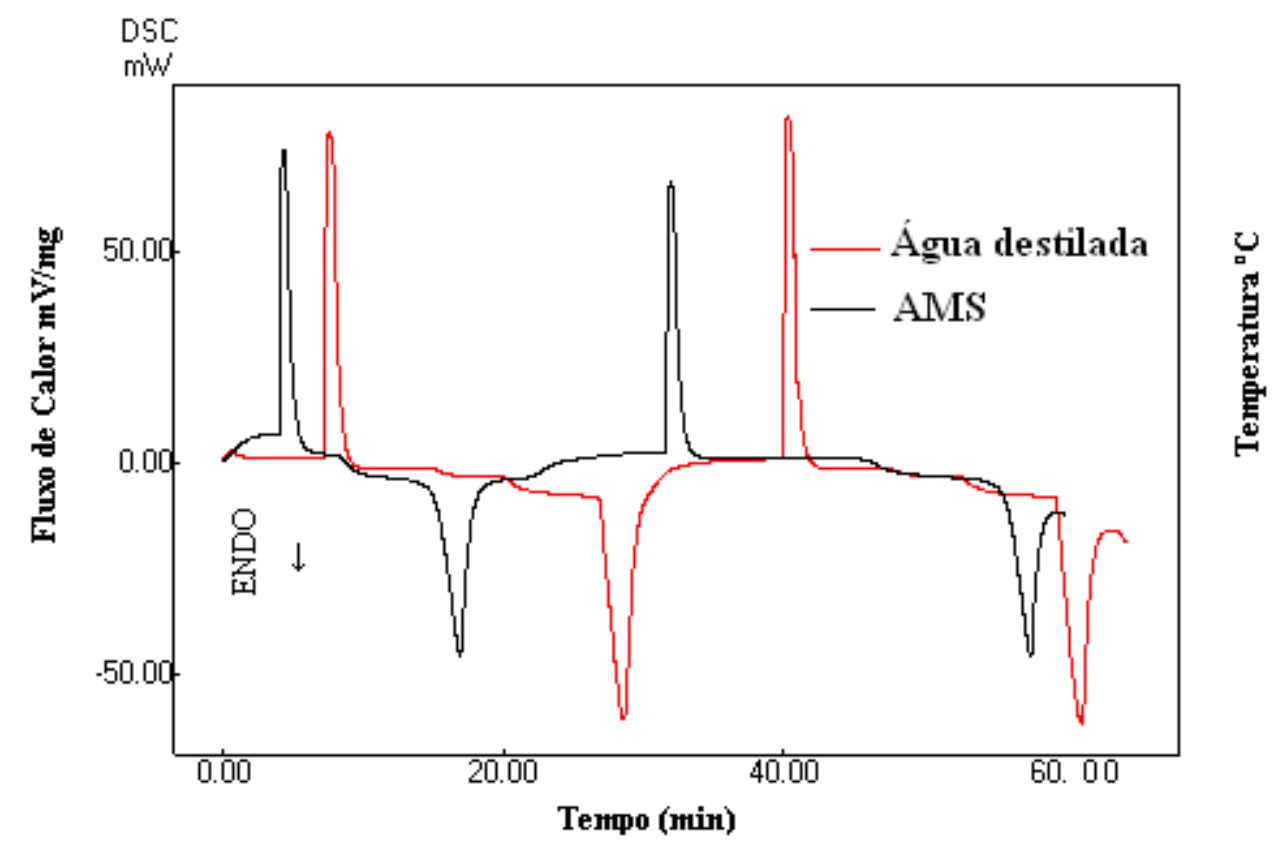

Figura 44. Curvas DSC da água destilada e do AMS obtidas nas seguintes condições: razão de aquecimento $5{ }^{\circ} \mathrm{C} / \mathrm{min}$, ciclos de resfriamento-aquecimento entre 25 e $-60{ }^{\circ} \mathrm{C}$, massa das amostras de 10,0 mg sob atmosfera dinâmica de $\mathrm{N}_{2}(100 \mathrm{~mL} / \mathrm{min})$. 


\subsubsection{Análise da distribuição de tamanho de partícula por difração a laser}

Tabela 7 . Distribuição do tamanho de partícula $(\mu \mathrm{m})$ do AMS por difração a laser.

\begin{tabular}{ccccc}
\hline Amostra & $\mathrm{D}[\mathrm{v}, 0.1]$ & $\mathrm{D}[\mathrm{v}, 0.5]$ & $\mathrm{D}[\mathrm{v}, 0.9]$ & $\mathrm{D}[4,3]$ \\
\hline $\begin{array}{c}\text { AMC(solução } \\
\text { aquosa à 1\%) }\end{array}$ & 2,967 & 27,15 & 80,04 & 34,36 \\
\hline
\end{tabular}

$\mathrm{D}[4,3]=$ Média da distribuição do tamanho de partículas*

$\mathrm{D}[\mathrm{v}, 0.9]=$ diâmetro $(\mu \mathrm{m})$ no qual passam $90 \%$ das partículas *

$\mathrm{D}[\mathrm{v}, 0.5]=$ diâmetro $(\mu \mathrm{m})$ no qual passam $50 \%$ das partículas *

$\mathrm{D}[\mathrm{v}, 0.1]=$ diâmetro $(\mu \mathrm{m})$ no qual passam $10 \%$ das partículas *

*tamanho medido por volume $(\mu \mathrm{m})$.

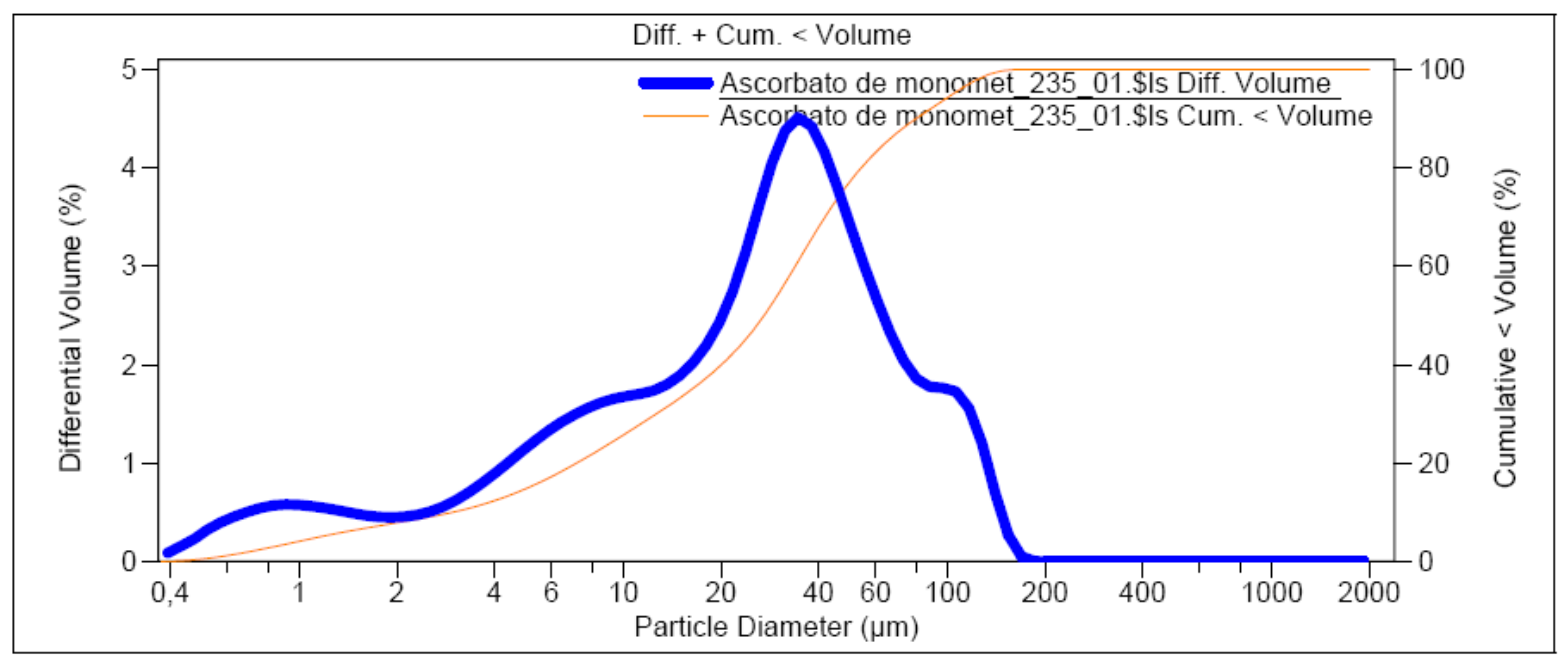

Figura 45. Gráfico da distribuição do tamanho de partícula do AMS (solução aquosa à

1\%) por difração a laser 


\subsubsection{Análise da distribuição de tamanho de partícula por espalhamento dinâmico de}

luz

O AMS (solução aquosa à 1\%), apresentou como medida do diâmetro interno das partículas, o valor de aproximadamente $1 \mu \mathrm{m}$ e índice de polidispersividade (PDI) de 0,1.

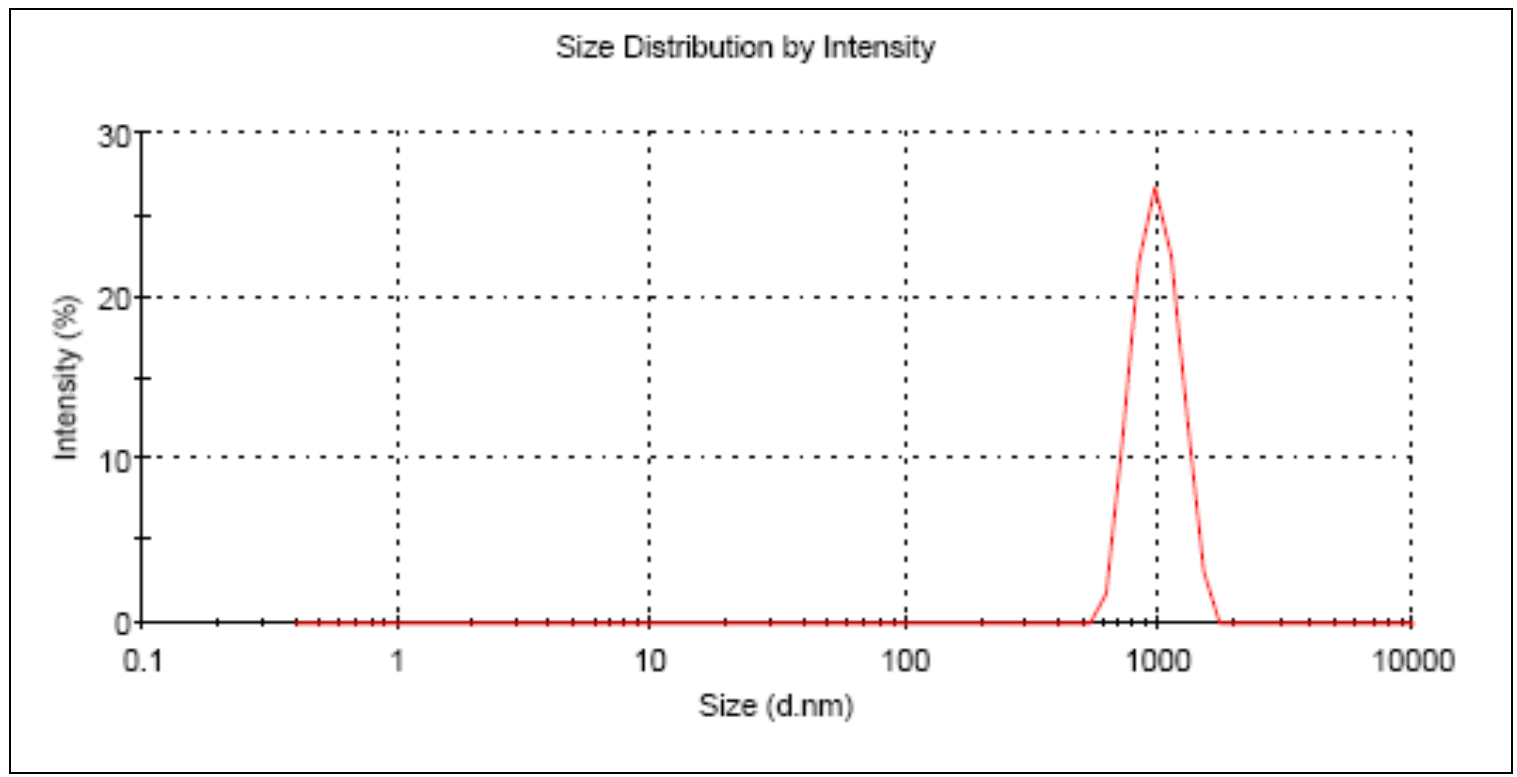

Figura 46. Gráfico da distribuição do tamanho de partícula do AMS (solução aquosa à 1\%) por espalhamento dinâmico de luz. 


\subsection{Avaliação do potencial Antioxidante in vitro do AMS}

\subsubsection{Determinação da atividade antioxidante pela reação com DPPH ( 2,2'-difenil-1-}

picrilhidrazil )

Os resultados estatísticos obtidos na determinação da atividade antioxidante pela reação com DPPH ( 2,2'-difenil-1-picrilhidrazil ) estão nas Figuras 47 e 48 . O ácido ascórbico apresentou E50 de 6,65 $\mu \mathrm{g} / \mathrm{ml}$ e o AMS (solução aquosa à 1\%) apresentou EC50 de 5,92 $\mu \mathrm{g} / \mathrm{ml}$. Para verificar se a diferença entre os valores para AA e AMS foram significativos, foi aplicado o teste $\mathrm{t}$ de Student e de acordo com esse teste, $\mathrm{P}=0.1408$ não é considerado significante.

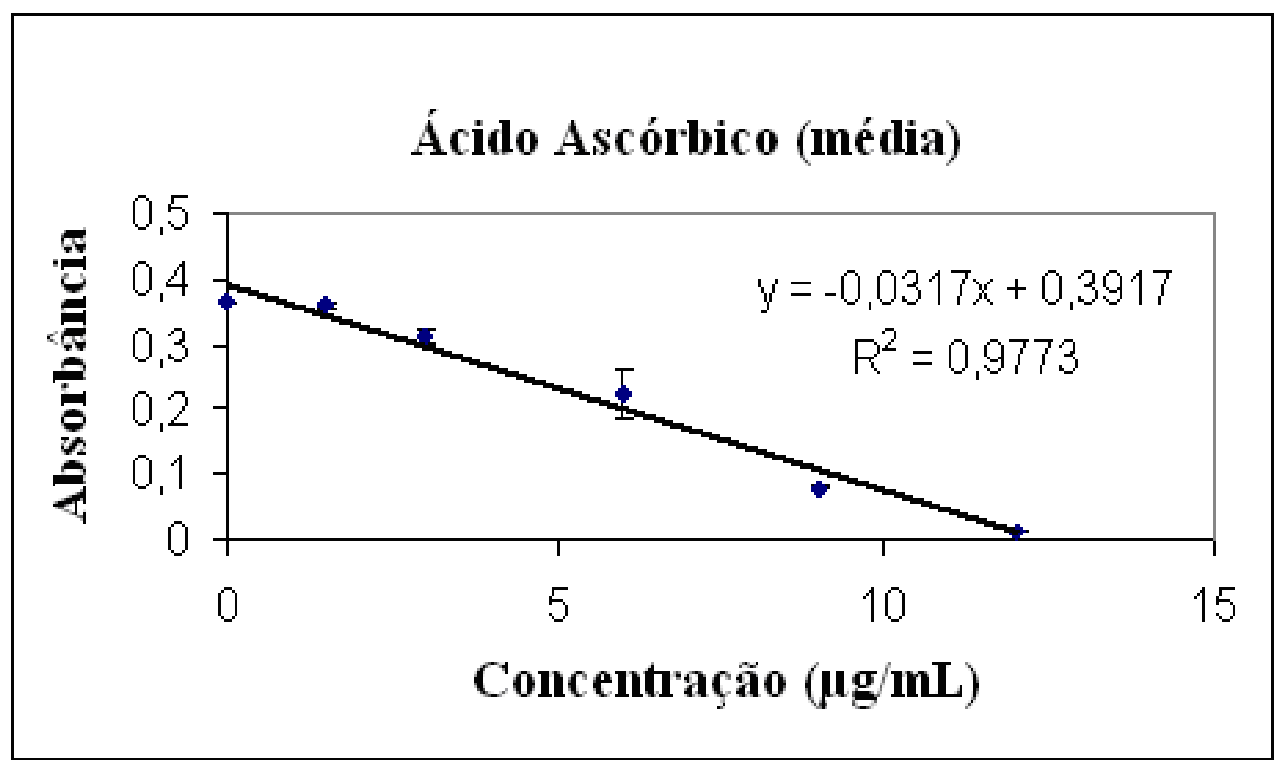

Figura 47. Avaliação estatística da atividade antioxidante do ácido ascórbico pela reação com DPPH. 


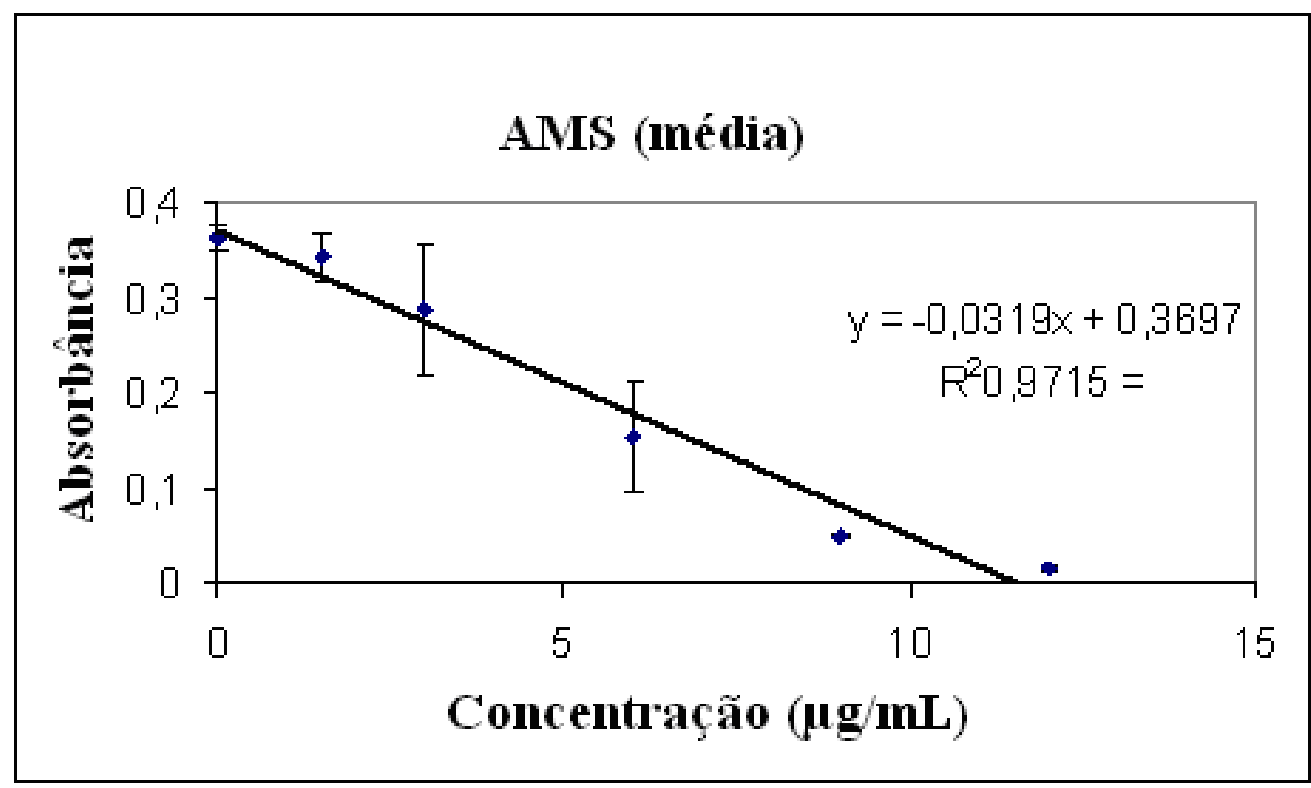

Figura 48. Avaliação estatística da atividade antioxidante do ácido ascórbico pela reação com DPPH. 


\subsubsection{Determinação do potencial antioxidante por fluorescência - ORAC (Oxigen}

\section{Radical Absorbance Capacity Assay)}

O valor final, calculado com base na equação de regressão linear entre a concentração de Trolox ${ }^{\circledR}$ e a área sob a curva de decaimento de fluorescência (AUC) foi de 0,74. A Figura 39 mostra a avaliação estatística da determinação do potencial antioxidante do AMS obtido com base no ORAC.

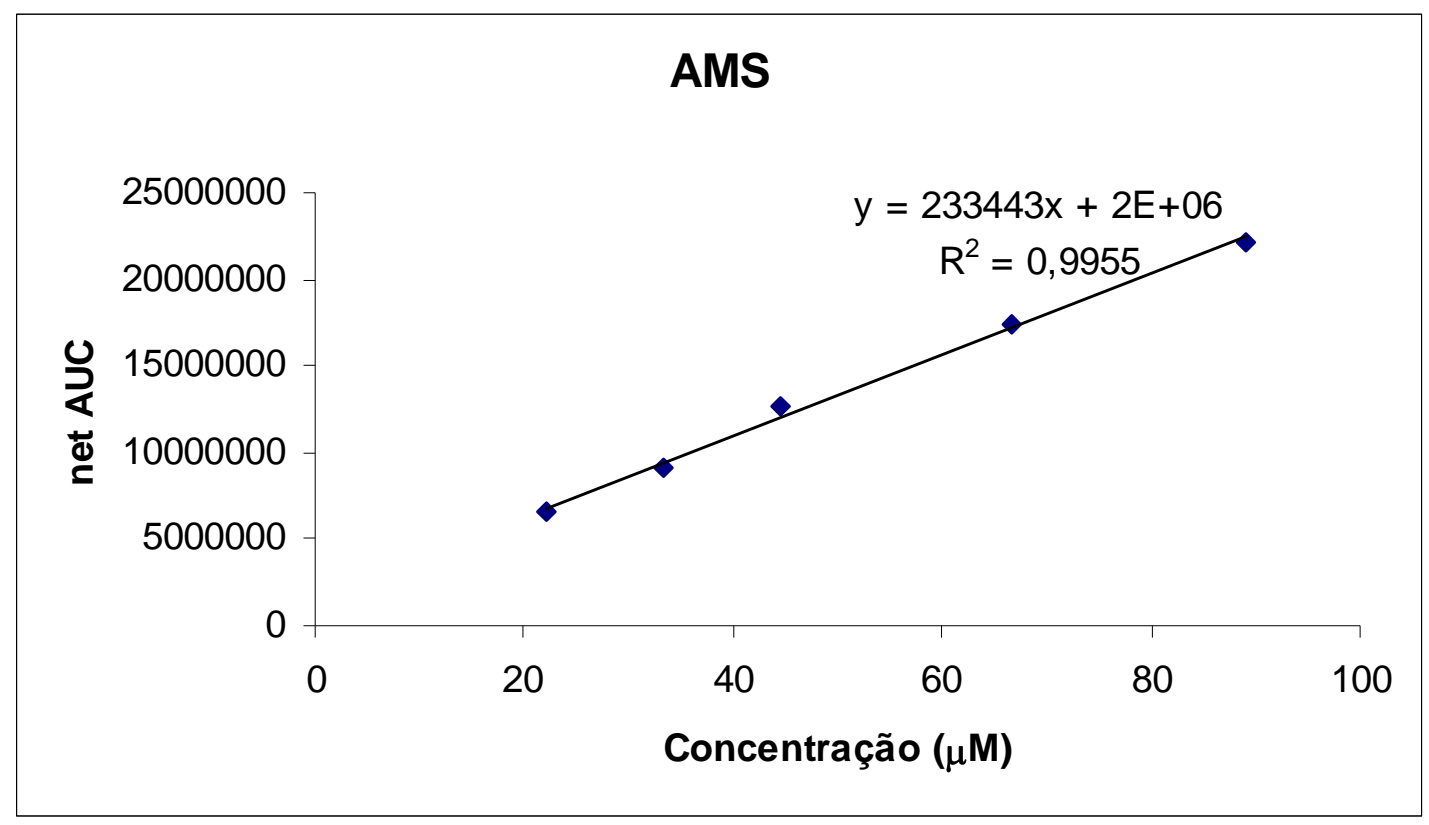

Figura 49. Avaliação estatística da determinação do potencial antioxidante do AMS obtido pelo ORAC. 


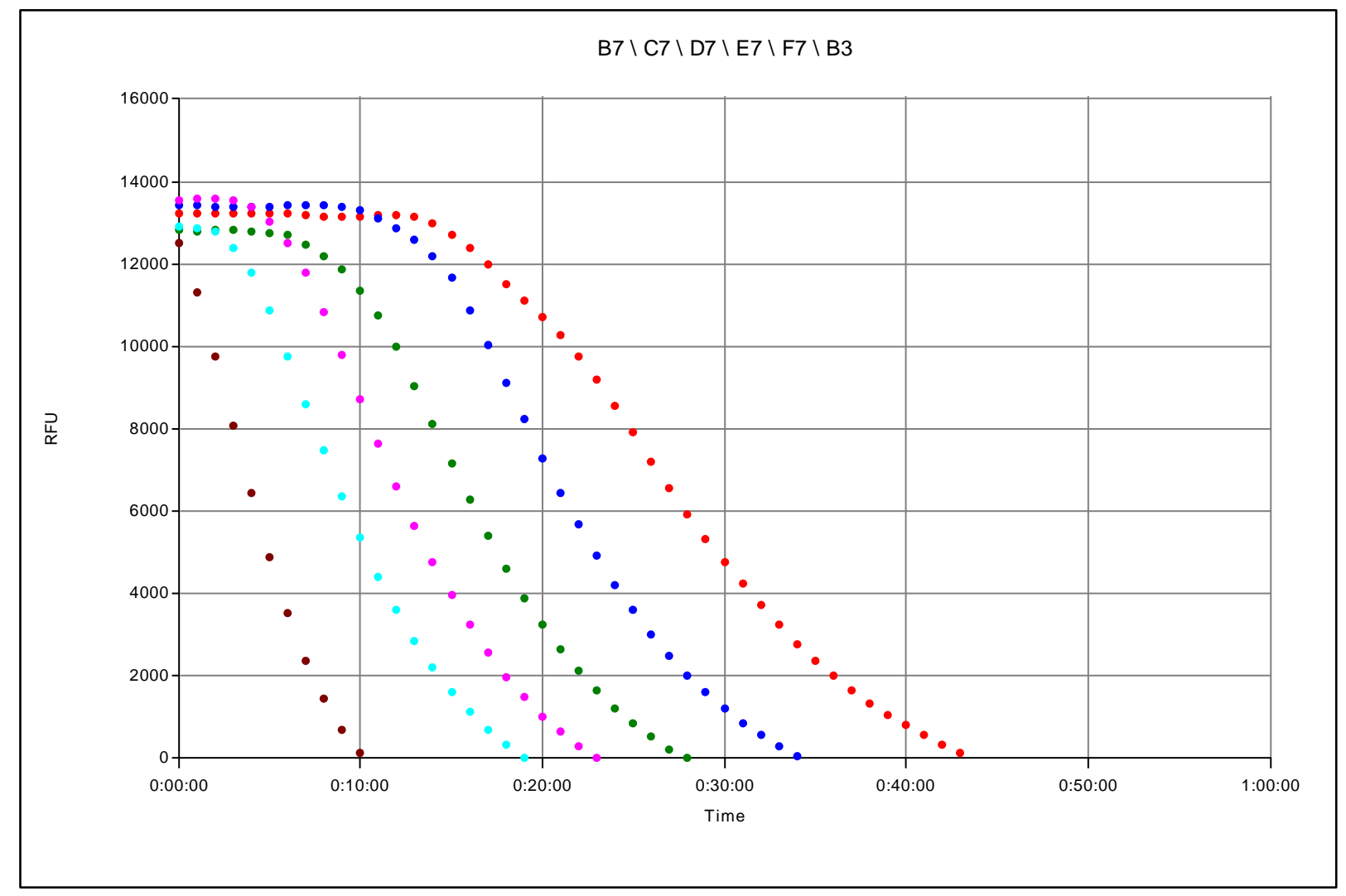

Figura 50. Efeito da concentração de Trolox sob a curva de decaimento de fluorescência, apresentando potencial antioxidante de 0,597 $\pm 0,043$ eq Trolox sendo que, a molaridade está baseada na concentração de ácido ascórbico presente na solução de ascorbato de monometilsilanotriol. 


\subsection{Avaliação das formulações cosméticas}

\subsubsection{Teste de estabilidade preliminar}

Tabela 8. Resultados obtidos nos testes preliminares de estabilidade

\begin{tabular}{ll}
\hline Formulação & $\begin{array}{l}\text { Centrifugação } \\
\mathbf{3 0 0 0}(\mathbf{r p m})\end{array}$ \\
\hline F1 & $\mathrm{N}$ \\
F1A & $\mathrm{N}$ \\
F2 & $\mathrm{N}$ \\
F2A & $\mathrm{N}$ \\
F3 & $\mathrm{N}$ \\
F3A & $\mathrm{N}$ \\
\hline
\end{tabular}

( $\mathbf{N}=$ Normal, sem alteração; $\mathbf{L M}=$ Levemente Modificado; $\mathbf{M}=$ Modificado;

$\mathbf{I M}=$ Intensamente Modificado) 


\subsubsection{Determinação do tipo de emulsão}

Tabela 9. Resultados obtidos nos testes de determinação do tipo de emulsão.

\begin{tabular}{ll}
\hline Formulação & Tipo de emulsão \\
\hline F1 & Emulsão O/A \\
F1A & Emulsão O/A \\
F2 & Emulsão O/A \\
F2A & Emulsão O/A \\
F3 & Emulsão O/A \\
F3A & Emulsão O/A \\
\hline
\end{tabular}

Os parâmetros empregados para classificação das emulsões foi:

a) Emulsão $\mathrm{A} / \mathrm{O}=$ solúvel em óleo mineral, formação de fase homogênea e sem grumos;

b) Emulsão $\mathrm{O} / \mathrm{A}=$ solúvel em água, formação de fase homogênea e sem grumos. 


\subsubsection{Teste de estabilidade acelerada}

Tabela 10. Características das formulações cosméticas no T0 (logo após a obtenção das formulações).

\begin{tabular}{llcccc}
\hline Formulação & Cor & Odor & Aspecto & pH & $\begin{array}{c}\text { Viscosidade } \\
\text { aparente } \\
\text { (cP) }\end{array}$ \\
\hline F1 & branco & característico & homogêneo & 5,32 & 12500 \\
F1A & branco & característico & homogêneo & 5,46 & 9300 \\
F2 & levemente & característico & homogêneo & 5,24 & 5200 \\
F2A & amarelada & & & & \\
& levemente & característico & homogêneo & 5,39 & 3400 \\
F3 & amarelada & & & & 16400 \\
F3A & branco & característico & homogêneo & 5,41 & 12000 \\
\hline & & & & & \\
\hline
\end{tabular}




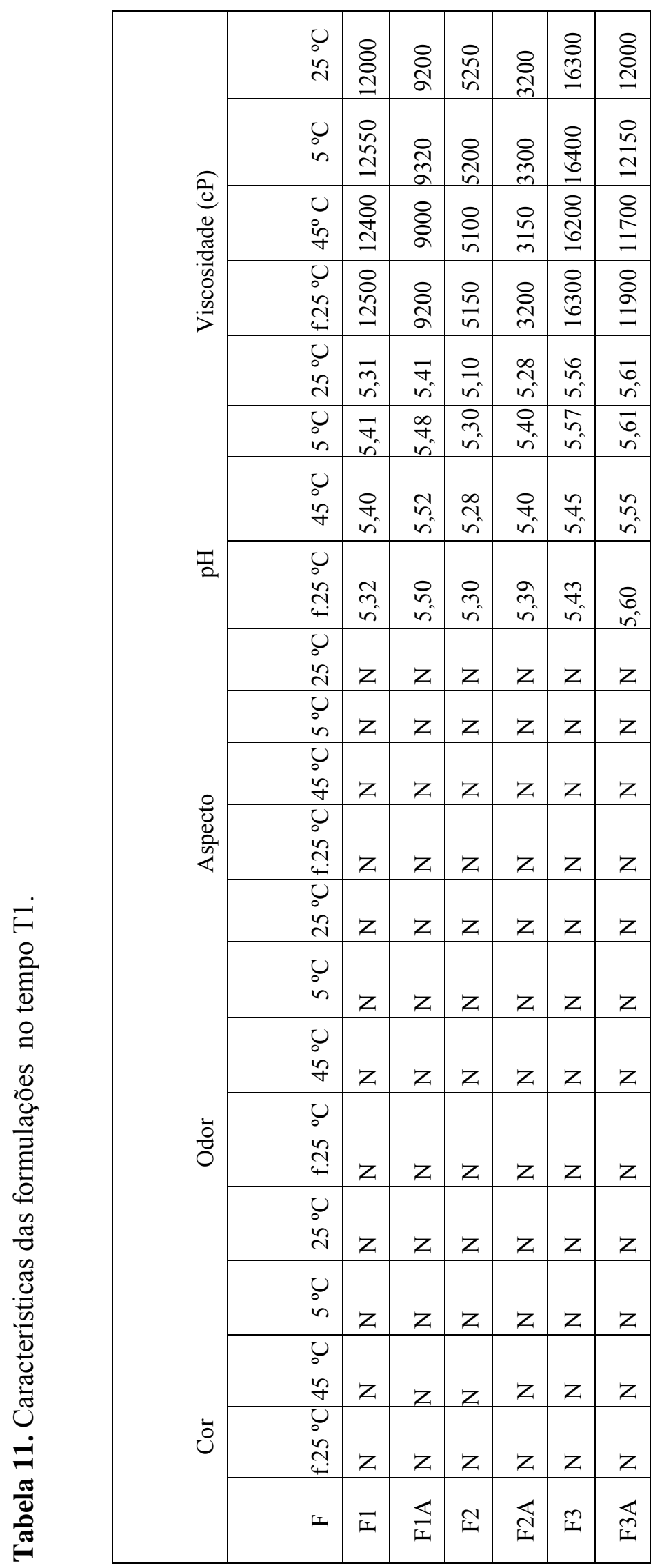




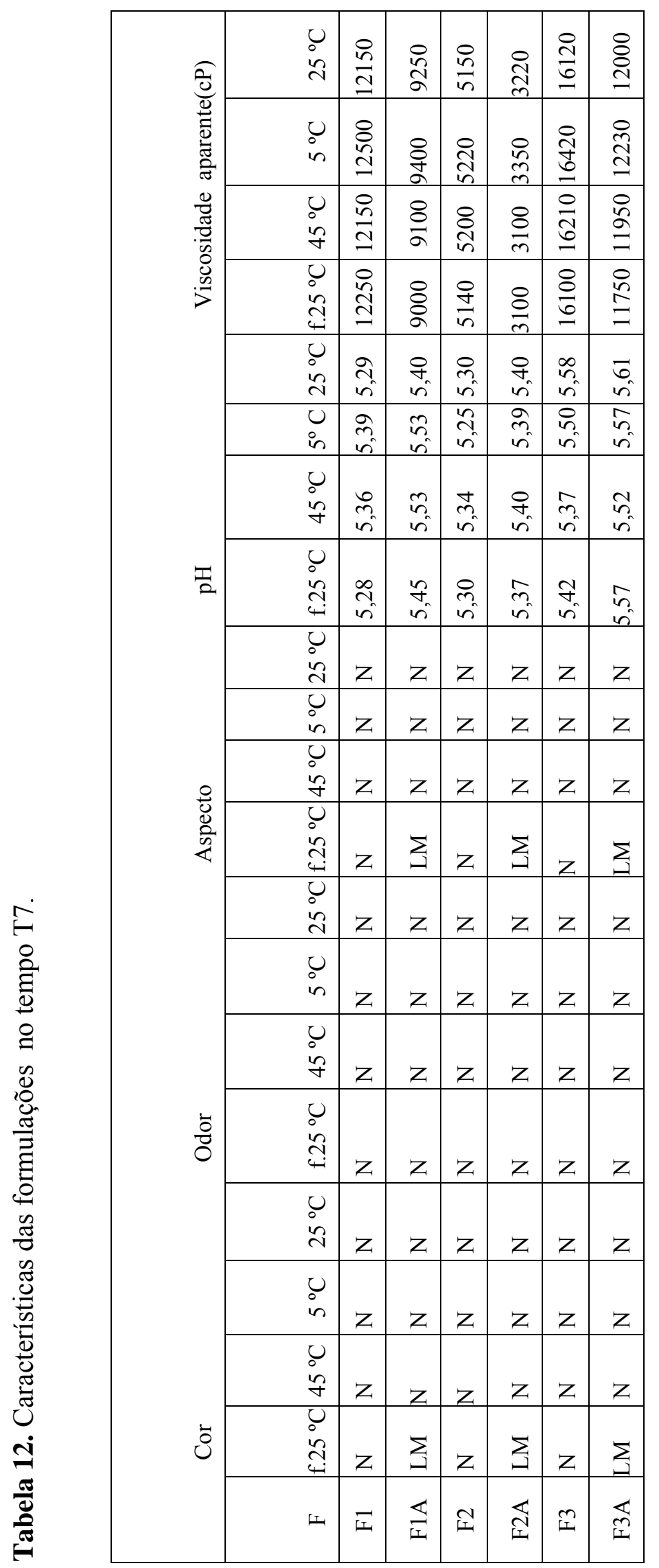




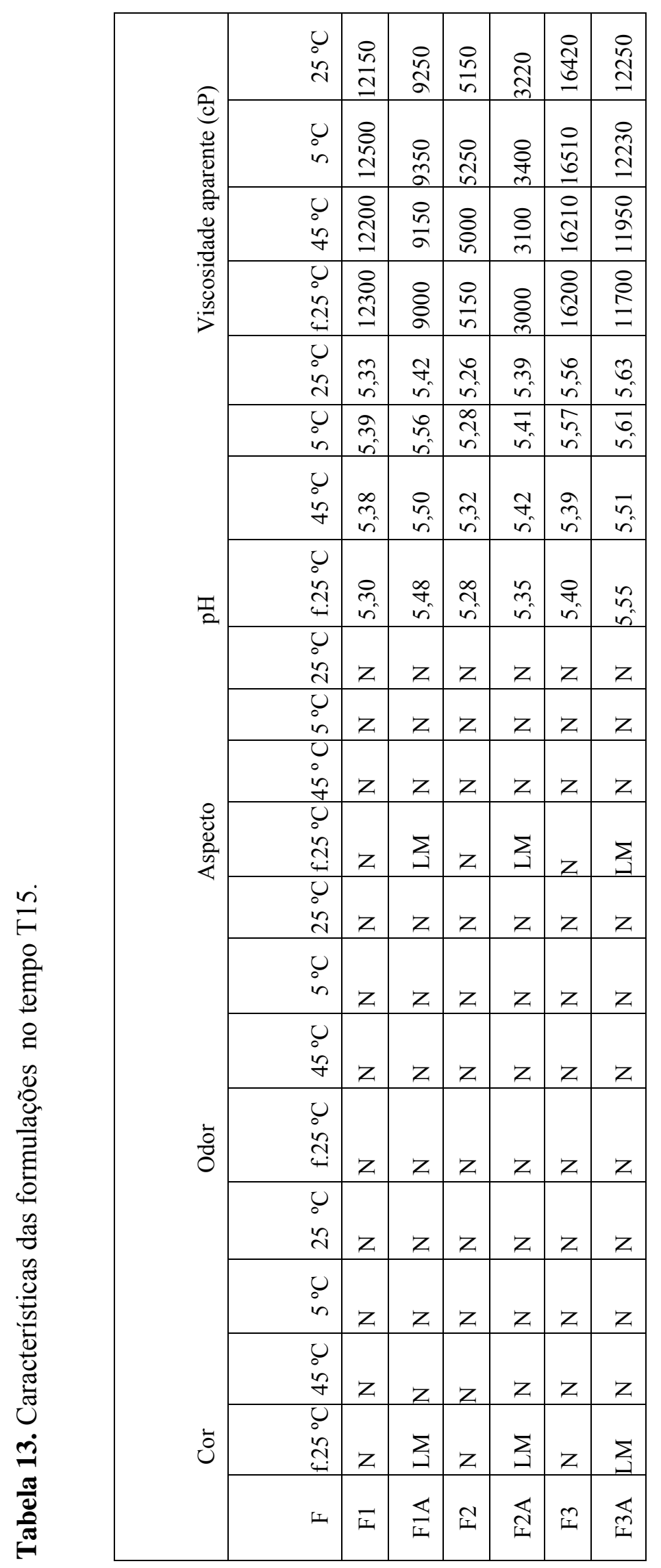




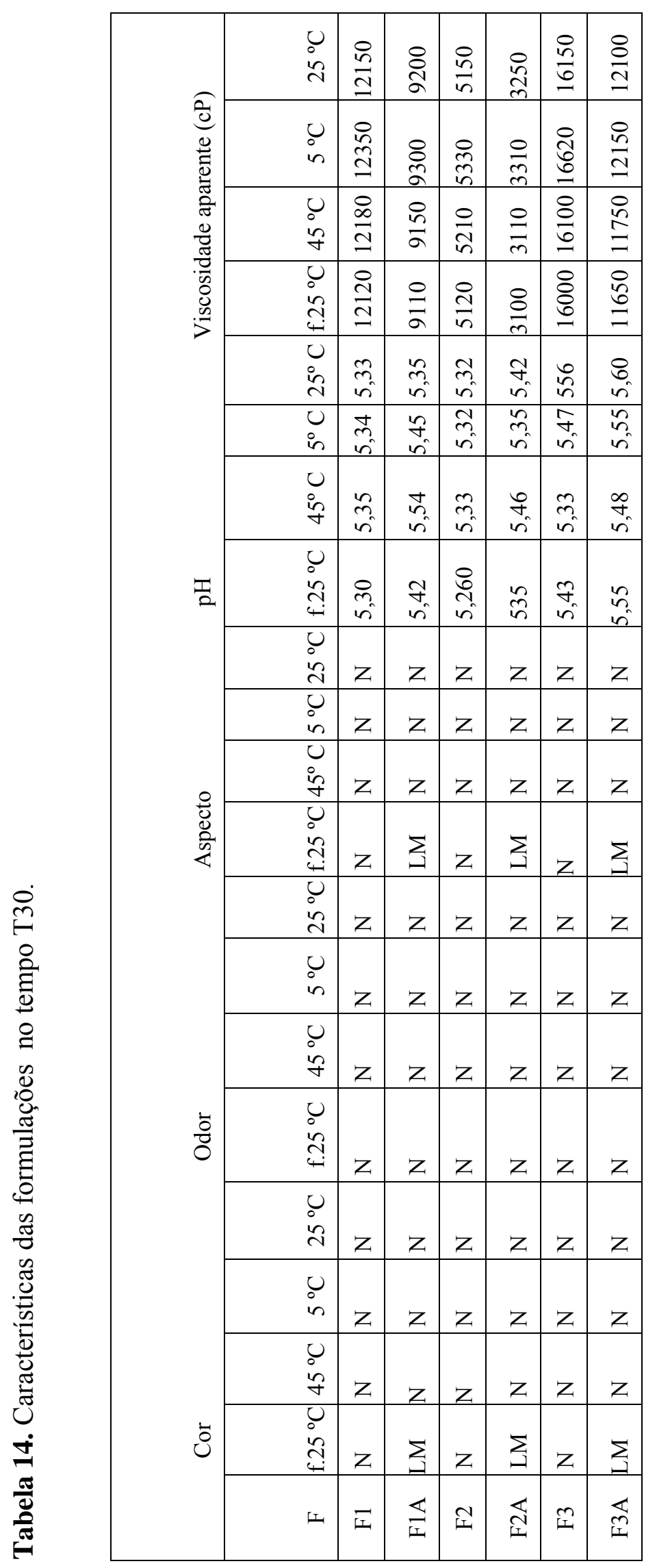




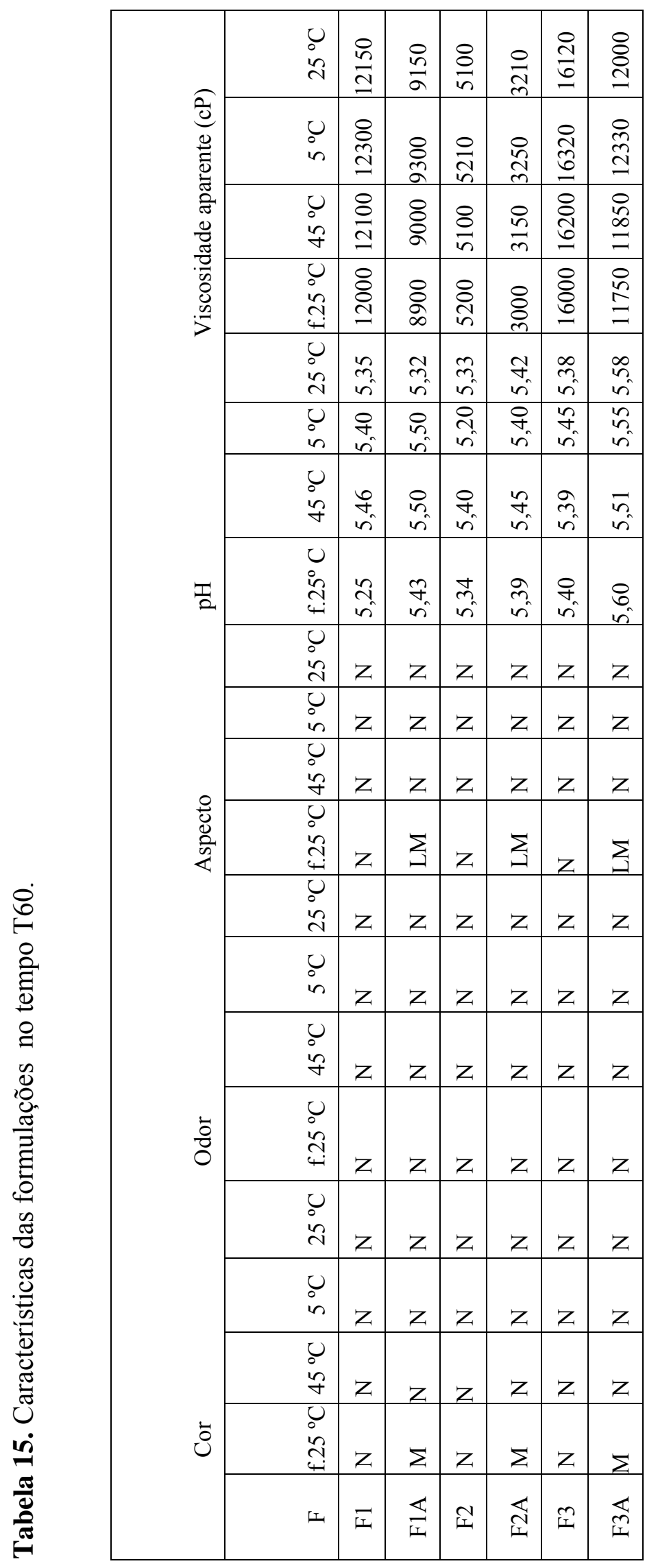




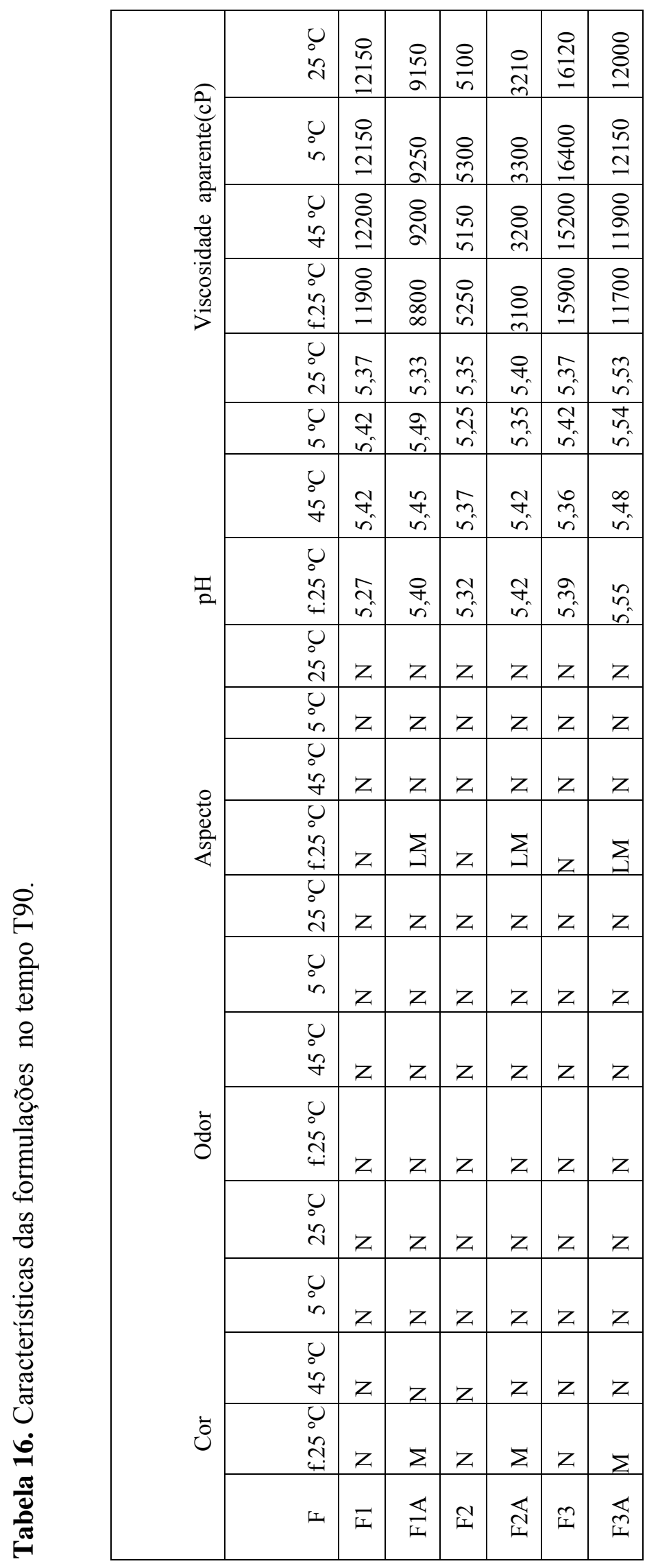


5.3.3.1. Visualização das cores das formulações submetidas ao teste de estabilidade acelerada

Os resultados das alterações das cores das formulações submetidas ao teste de estabilidade acelerada estão representados nas Figuras 44 à 47.

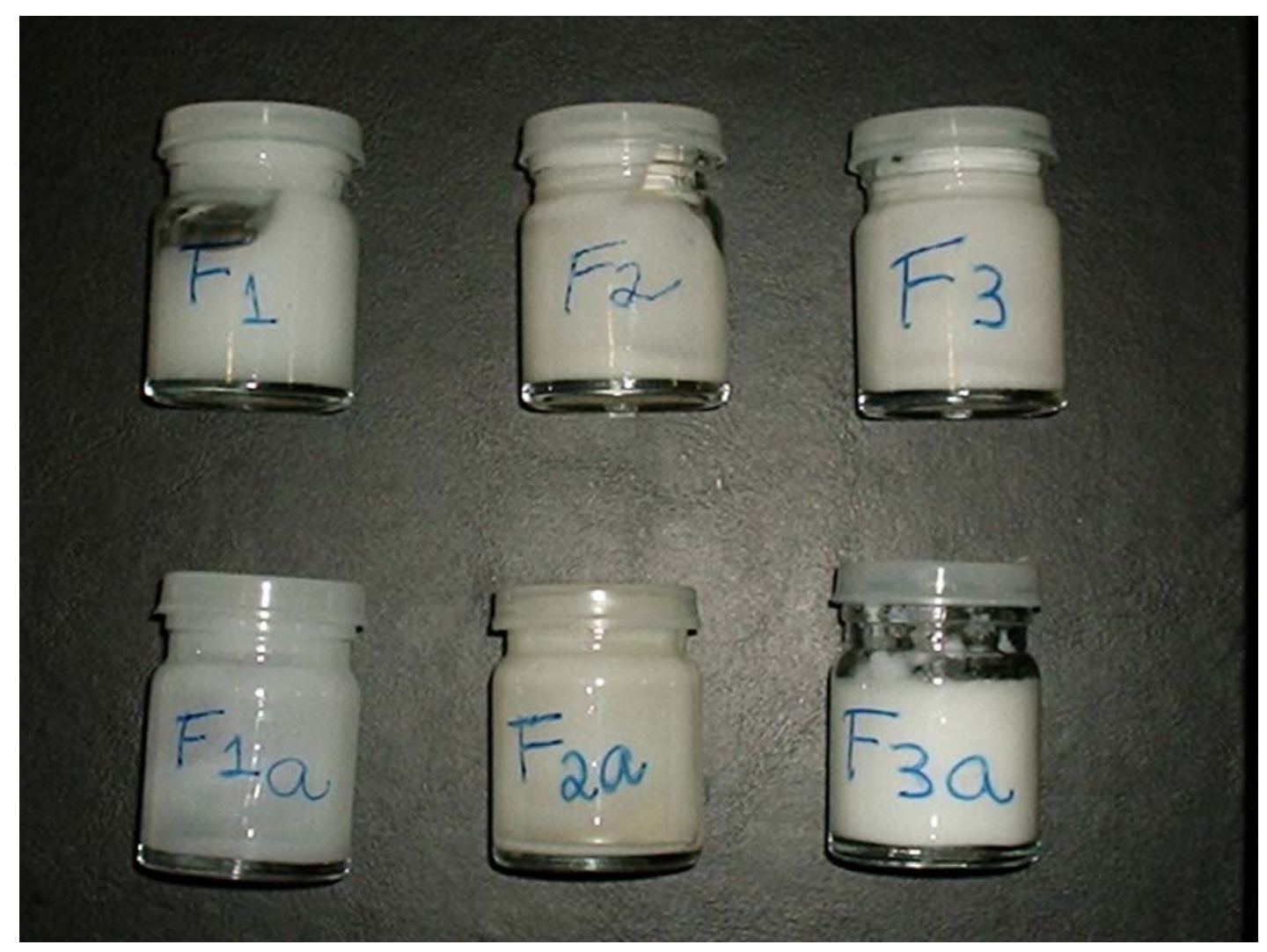

Figura 51. Fotografias das formulações, no (T1). 


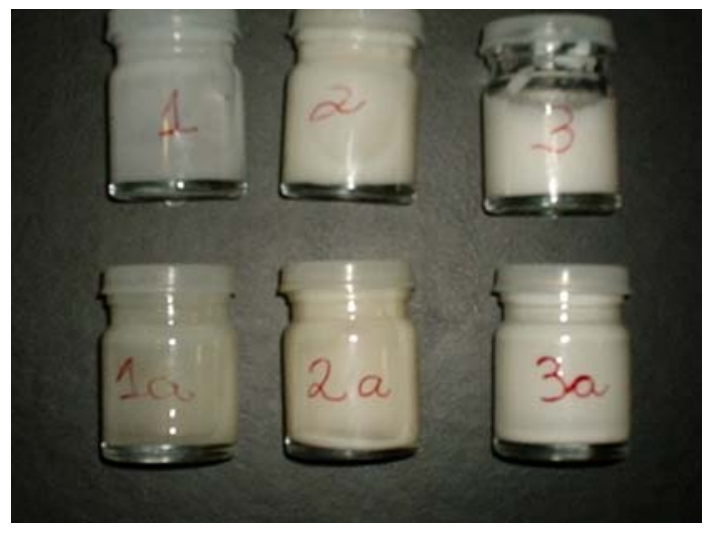

Fotoestabilidade $\left(25^{\circ} \mathrm{C}\right)$

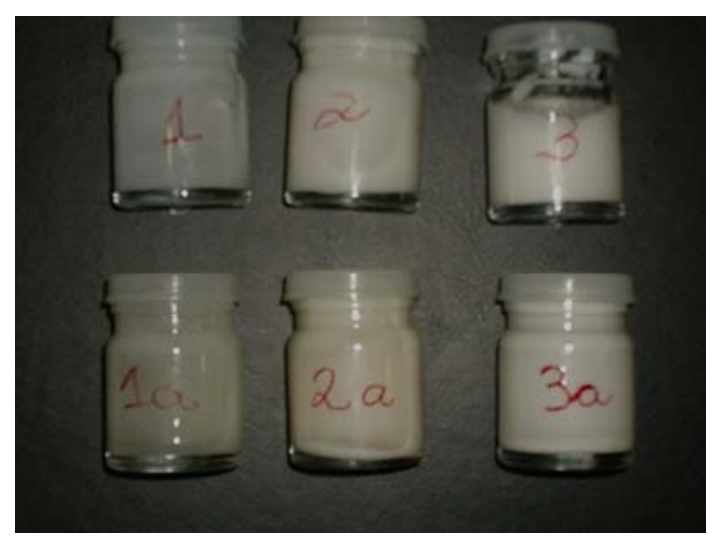

Temperatura de $25^{\circ} \mathrm{C}$

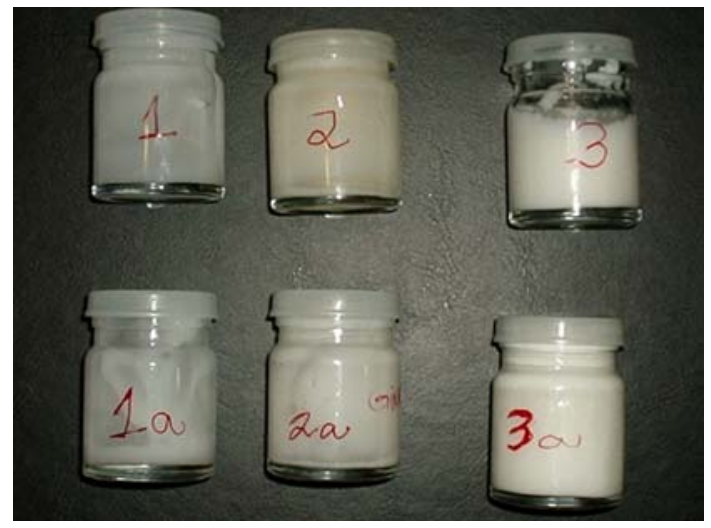

Temperatura de $45{ }^{\circ} \mathrm{C}$

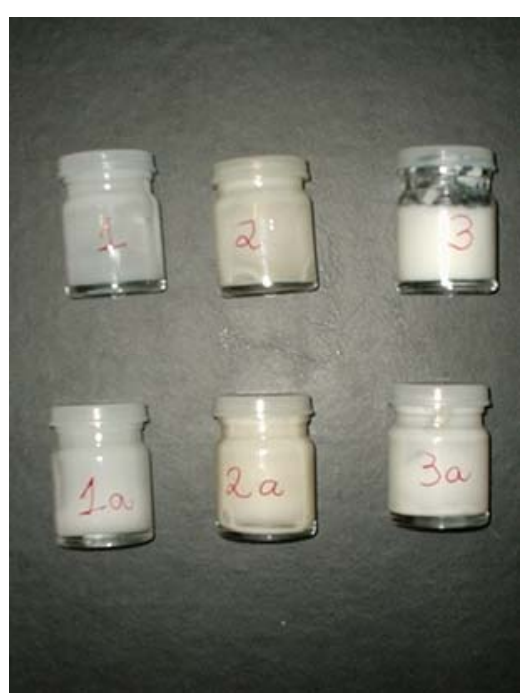

Temperatura de $5^{\circ} \mathrm{C}$

Figura 52. Fotografias das formulações no (T30). 


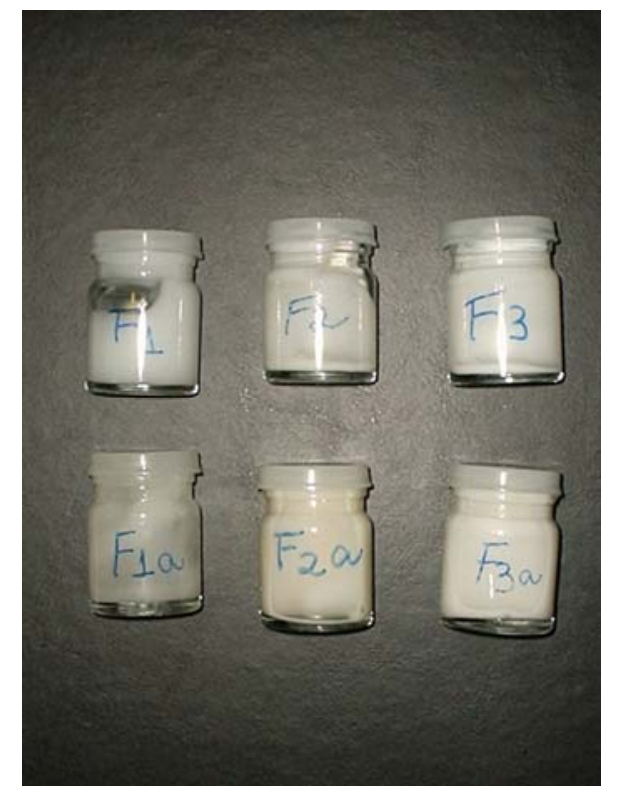

Fotoestabilidade $\left(25^{\circ} \mathrm{C}\right)$

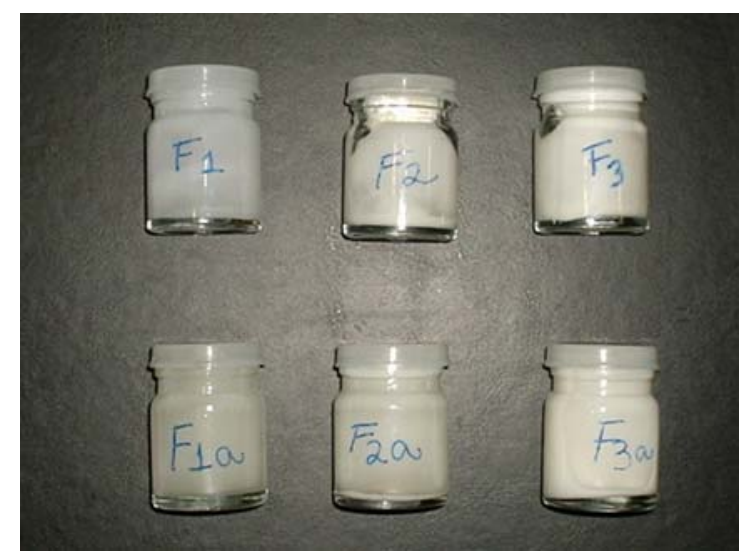

Temperatura de $25{ }^{\circ} \mathrm{C}$

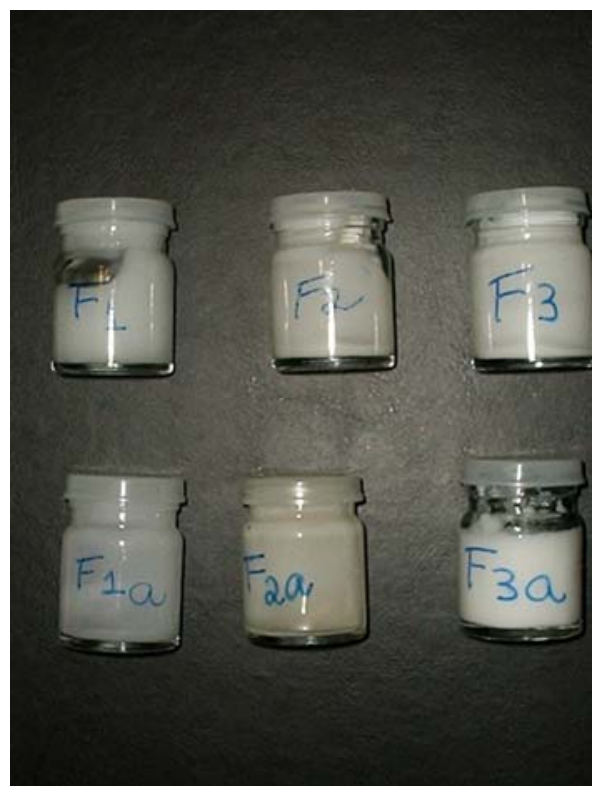

Temperatura de $45^{\circ} \mathrm{C}$

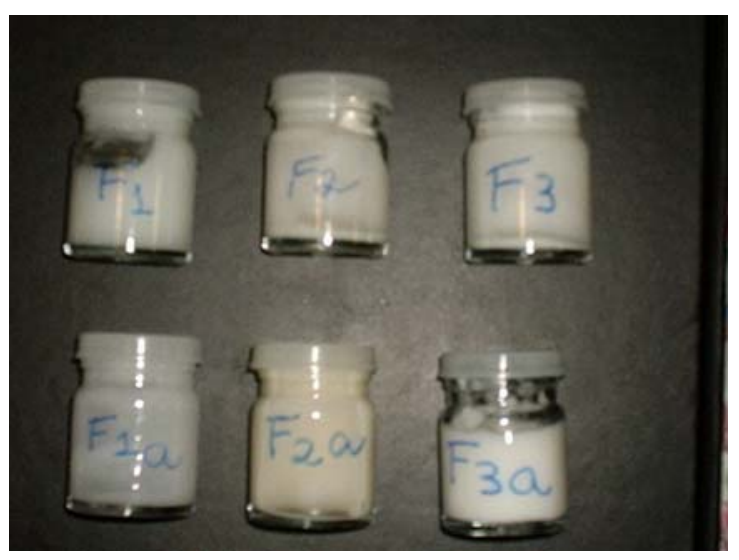

Temperatura de $5^{\circ} \mathrm{C}$

Figura 53. Fotografias das formulações no (T60). 


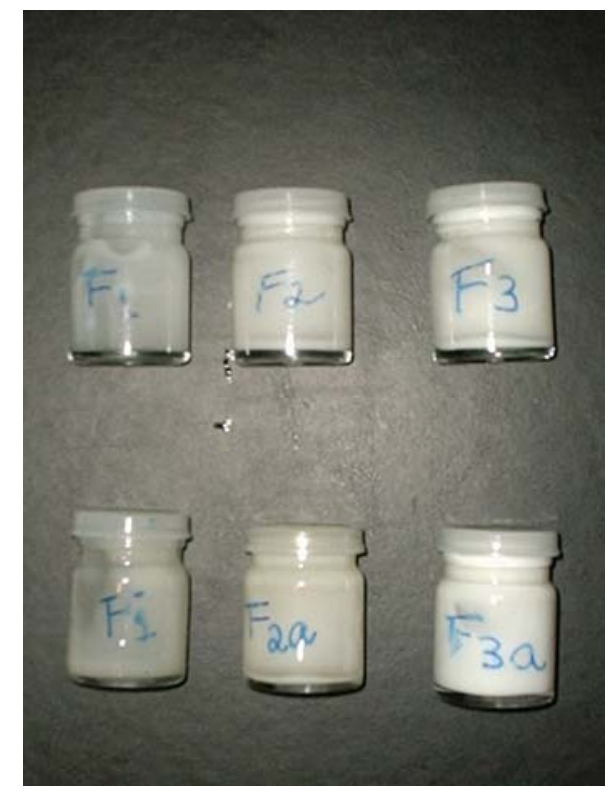

Fotoestabilidade $\left(25^{\circ} \mathrm{C}\right)$.

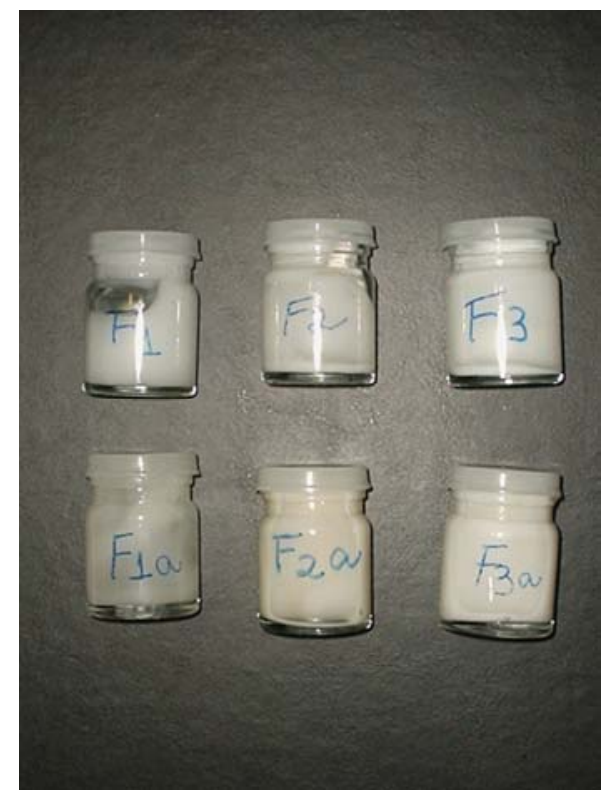

Temperatura de $25^{\circ} \mathrm{C}$.

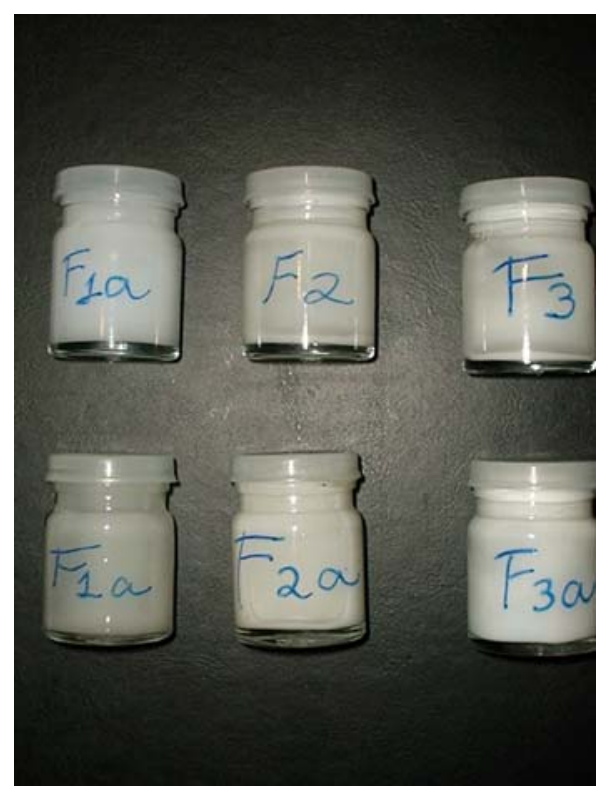

Temperatura de $45^{\circ} \mathrm{C}$.

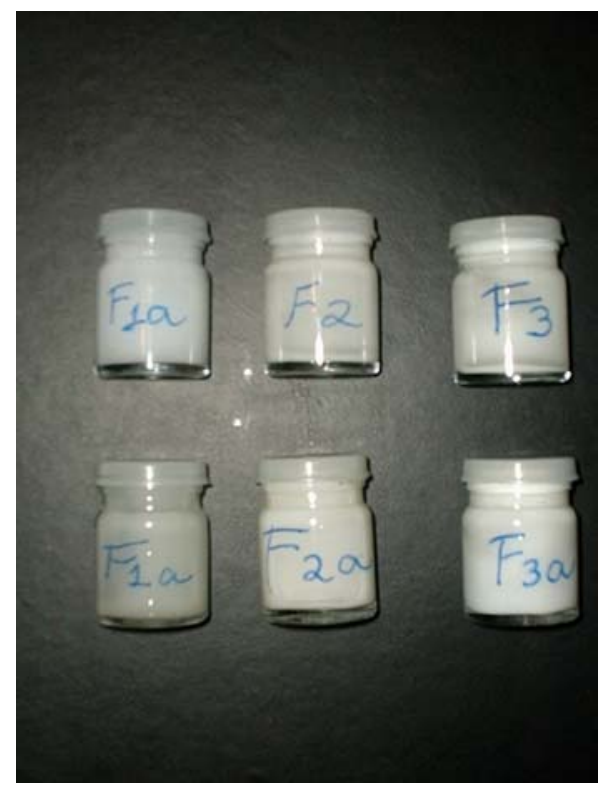

Temperatura de $5^{\circ} \mathrm{C}$.

Figura 54. Fotografias das formulações no (T30). 


\subsubsection{Análise de tamanho de partícula por difração a laser}

Tabela 17. Distribuição do tamanho de partícula $(\mu \mathrm{m})$ das formulações cosméticas por difração a laser.

\begin{tabular}{ccccc}
\hline Amostra & $\mathrm{D}[\mathrm{v}, 0.1]$ & $\mathrm{D}[\mathrm{v}, 0.5]$ & $\mathrm{D}[\mathrm{v}, 0.9]$ & $\mathrm{D}[4,3]$ \\
\hline F1 & 2,287 & 4,623 & 8,940 & 5,189 \\
F1A & 2,765 & 5,578 & 10,04 & 6,034 \\
F2 & 1,668 & 3,501 & 9,313 & 5,025 \\
F2A & 1,670 & 3,492 & 9,109 & 5,049 \\
F3 & 1,800 & 6,672 & 28,30 & 12,12 \\
F3A & 1,807 & 8,190 & 29,79 & 12,91 \\
\hline
\end{tabular}

$\mathrm{D}[4,3]=$ Média da distribuição do tamanho de partículas* $\mathrm{D}[\mathrm{v}, 0.9]=$ diâmetro $(\mu \mathrm{m})$ no qual $90 \%$ das partículas passam* $\mathrm{D}[\mathrm{v}, 0.5]=$ diâmetro $(\mu \mathrm{m})$ no qual $50 \%$ das partículas passam* $\mathrm{D}[\mathrm{v}, 0.1]=$ diâmetro $(\mu \mathrm{m})$ no qual $10 \%$ das partículas passam* *tamanho medido por volume $(\mu \mathrm{m})$. 


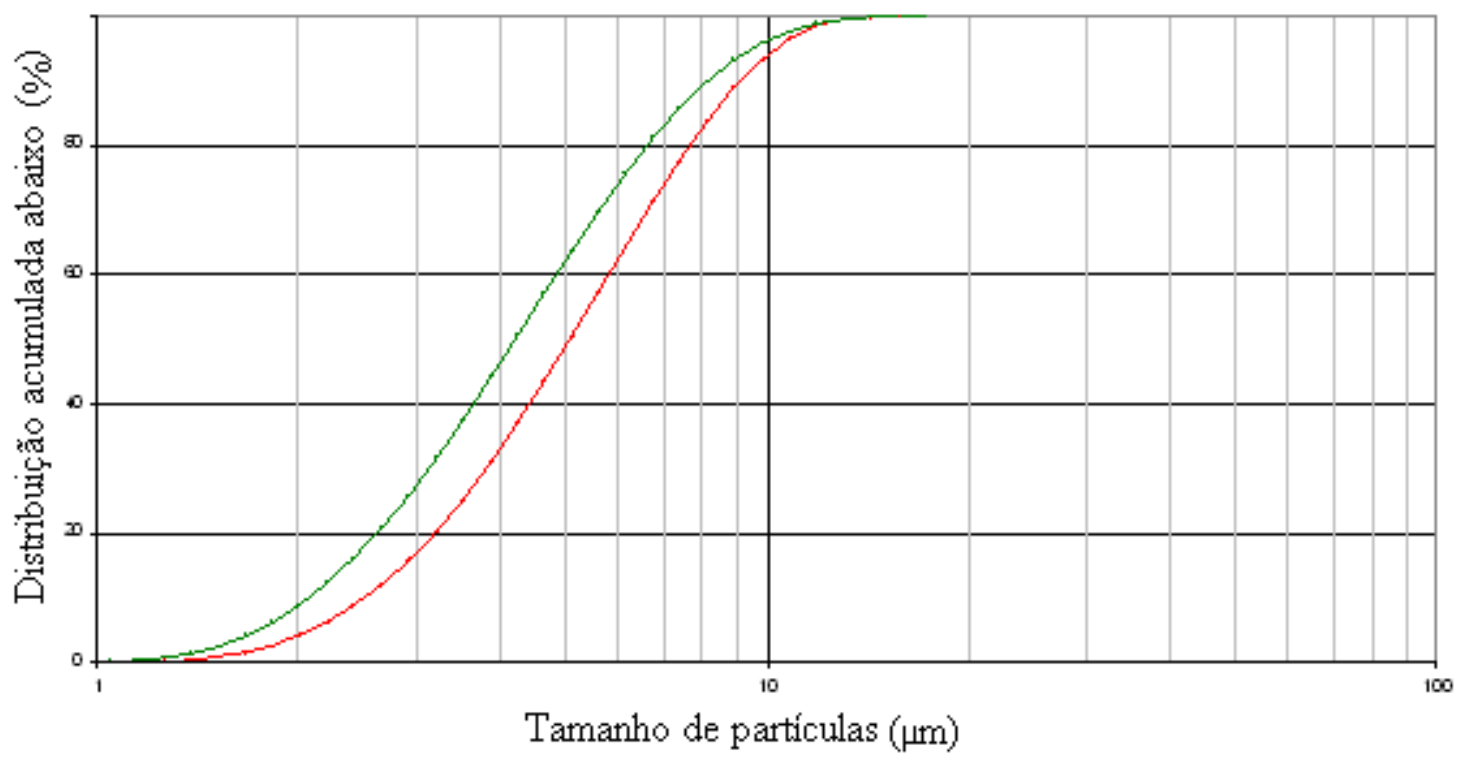

$-\mathrm{F} 1+\mathrm{F} 1 \mathrm{~A}$

Figura 55. Gráfico da distribuição do tamanho de partícula das formulações F1 e F1A. 


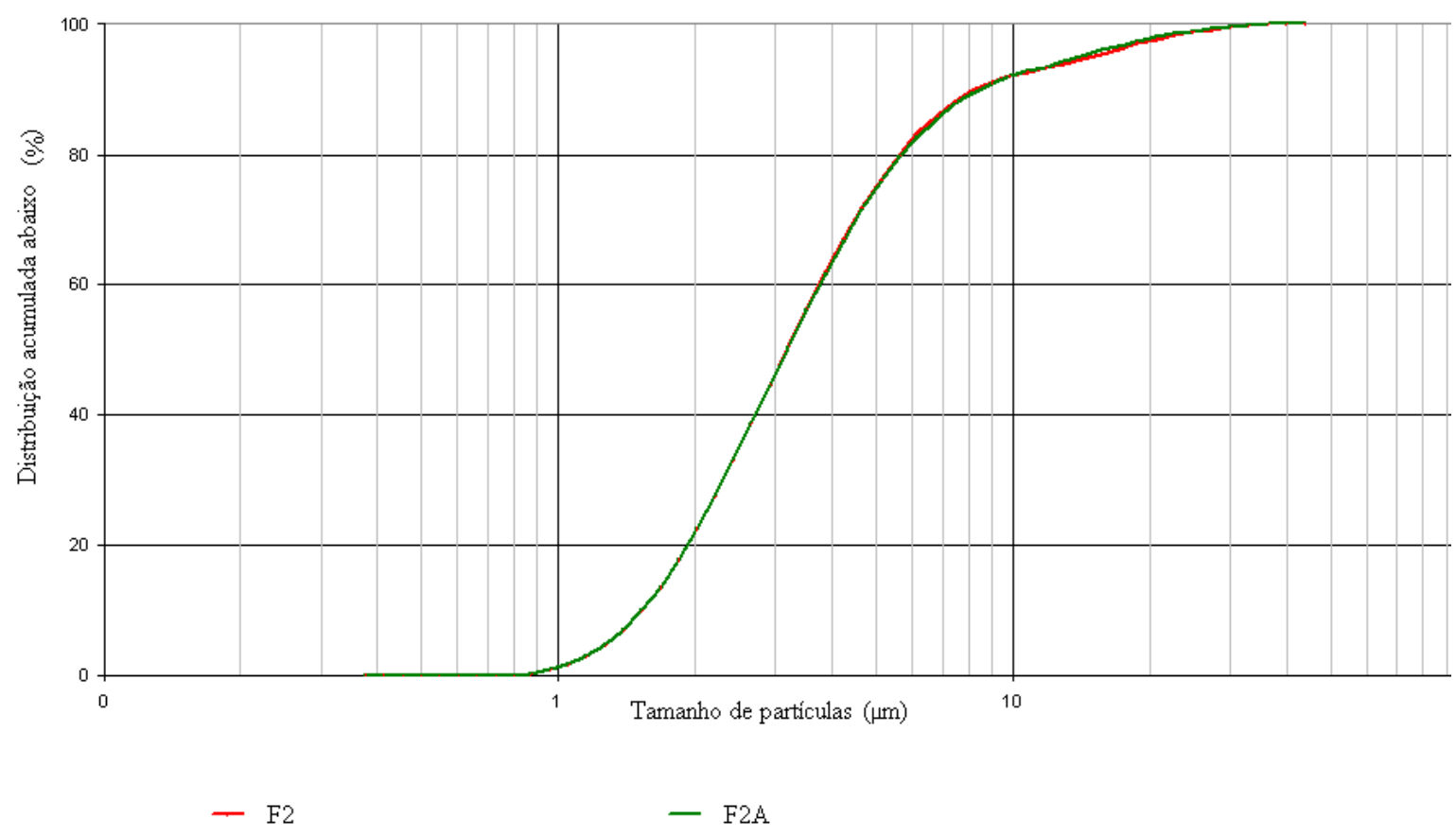

Figura 56. Gráfico da distribuição do tamanho de partícula das formulações F2 e F2A. 


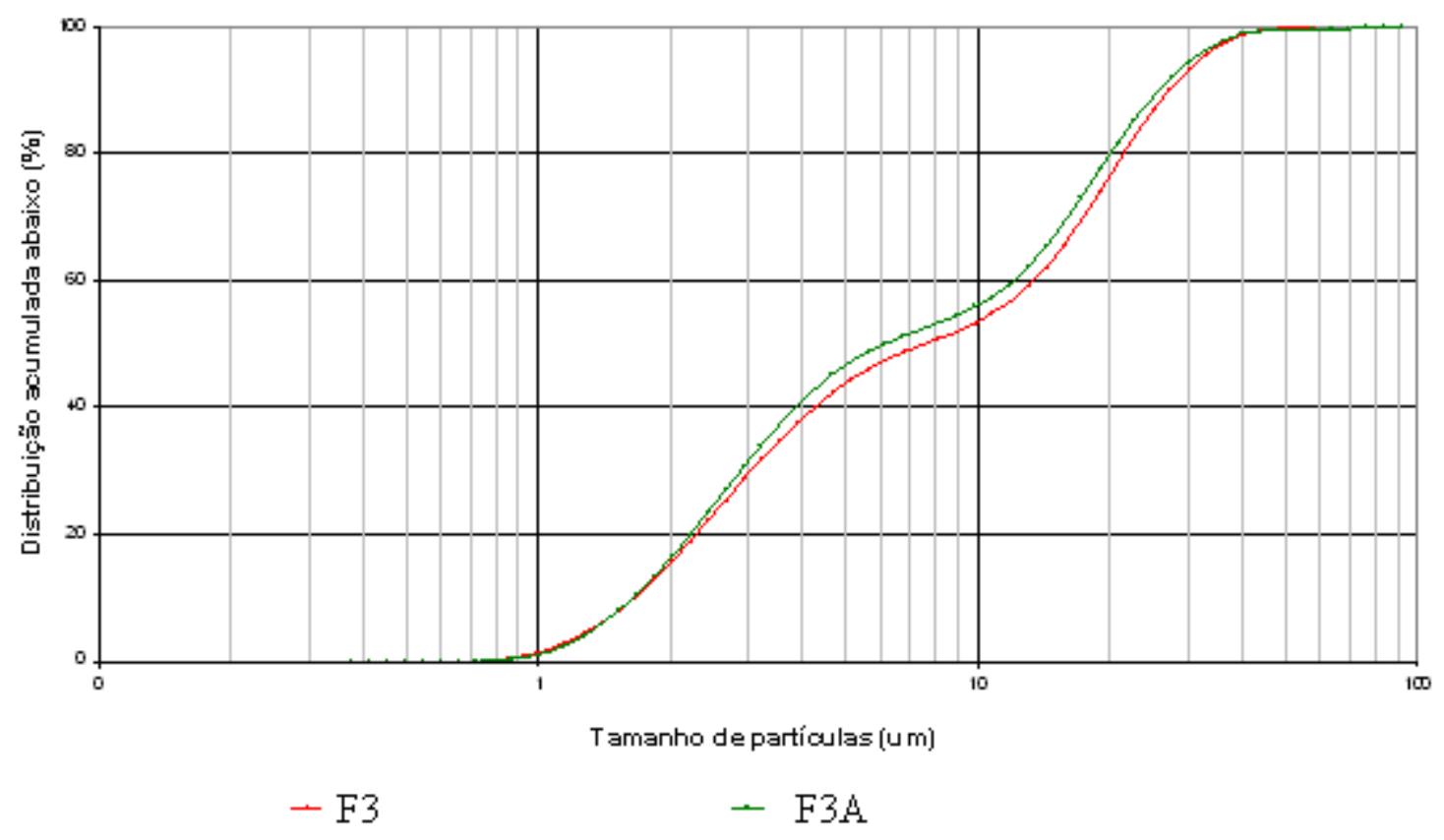

Figura 57. Gráfico da distribuição do tamanho de partícula das formulações F3 e F3A. 


\subsubsection{Análise microscópica das formulações}

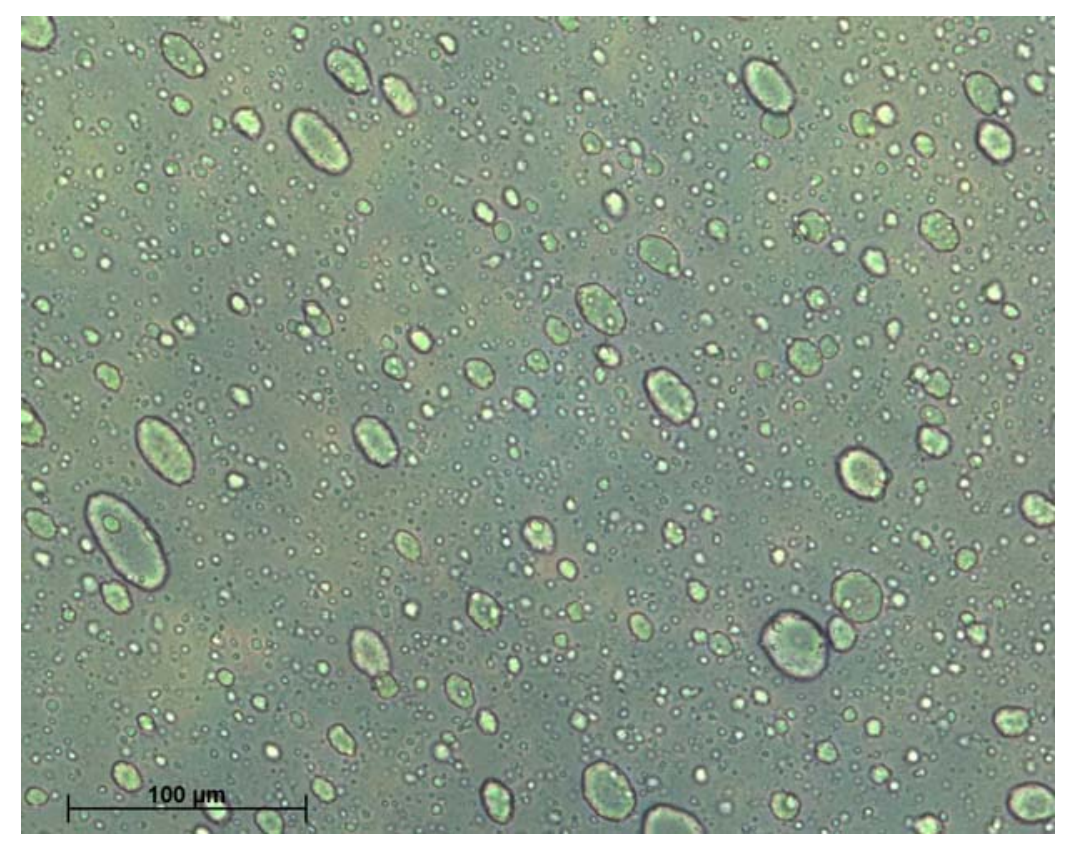

A (F1)

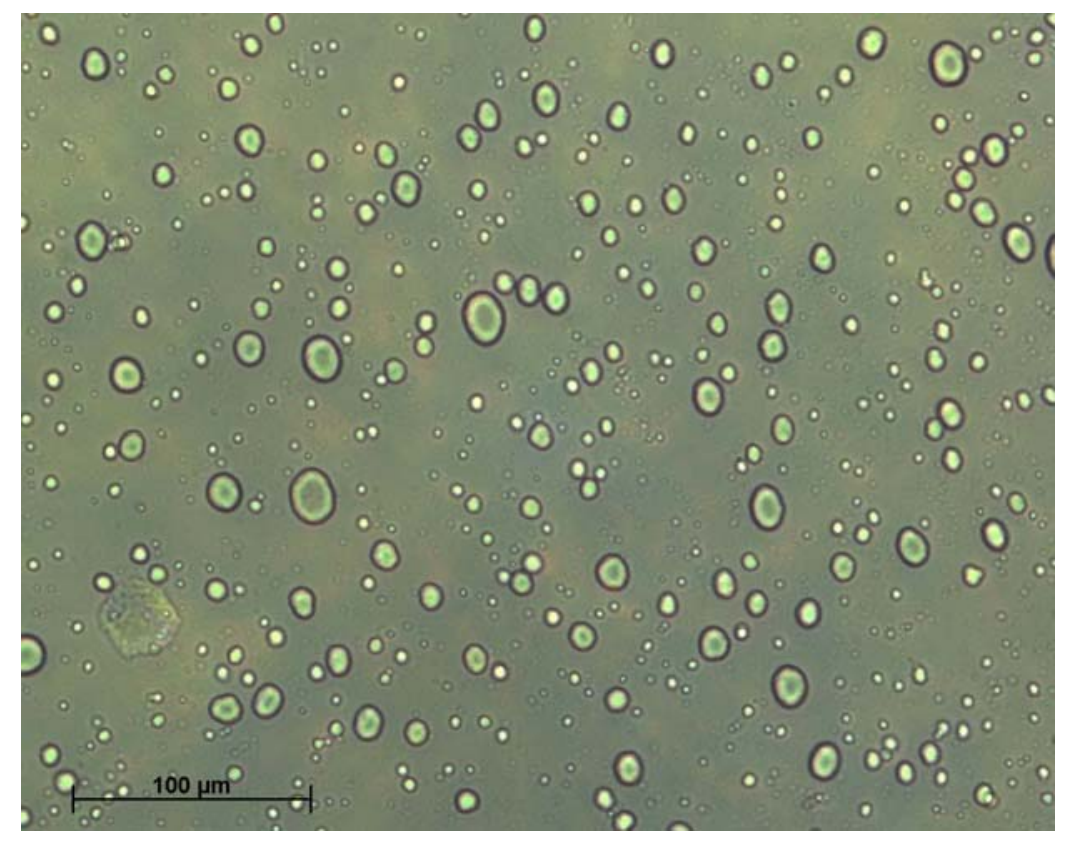

B (F1A)

Figura 58. Fotomicrografias sob luz polarizada das formulações A(F1) e B(F1A). 


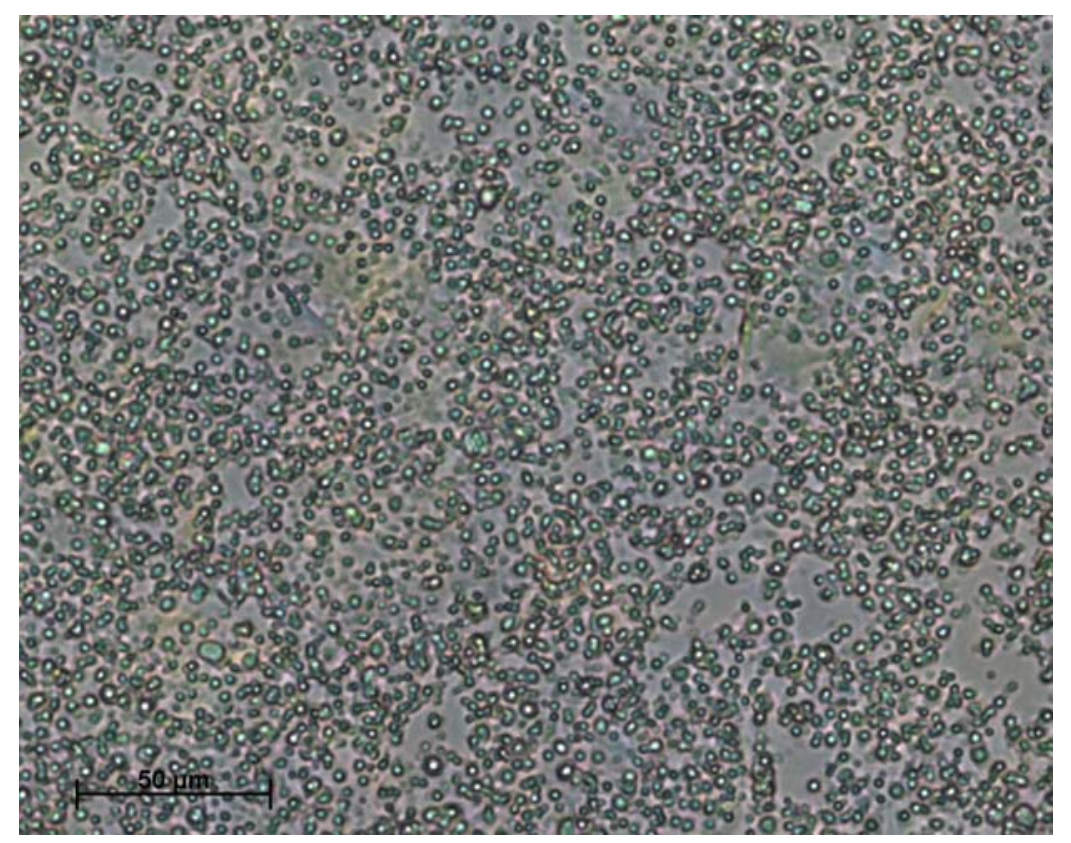

A (F2)

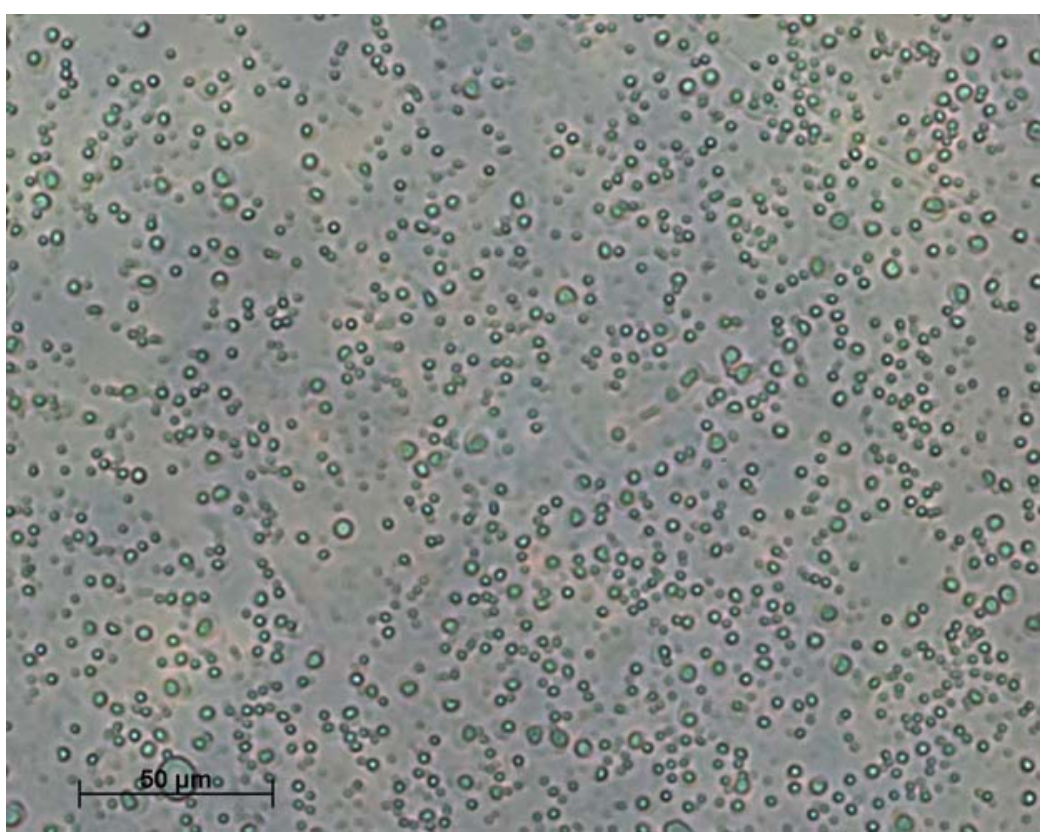

\section{B (F2A)}

Figura 59. Fotomicrografias sob luz polarizada das formulações $A(F 2)$ e B(F2A). 


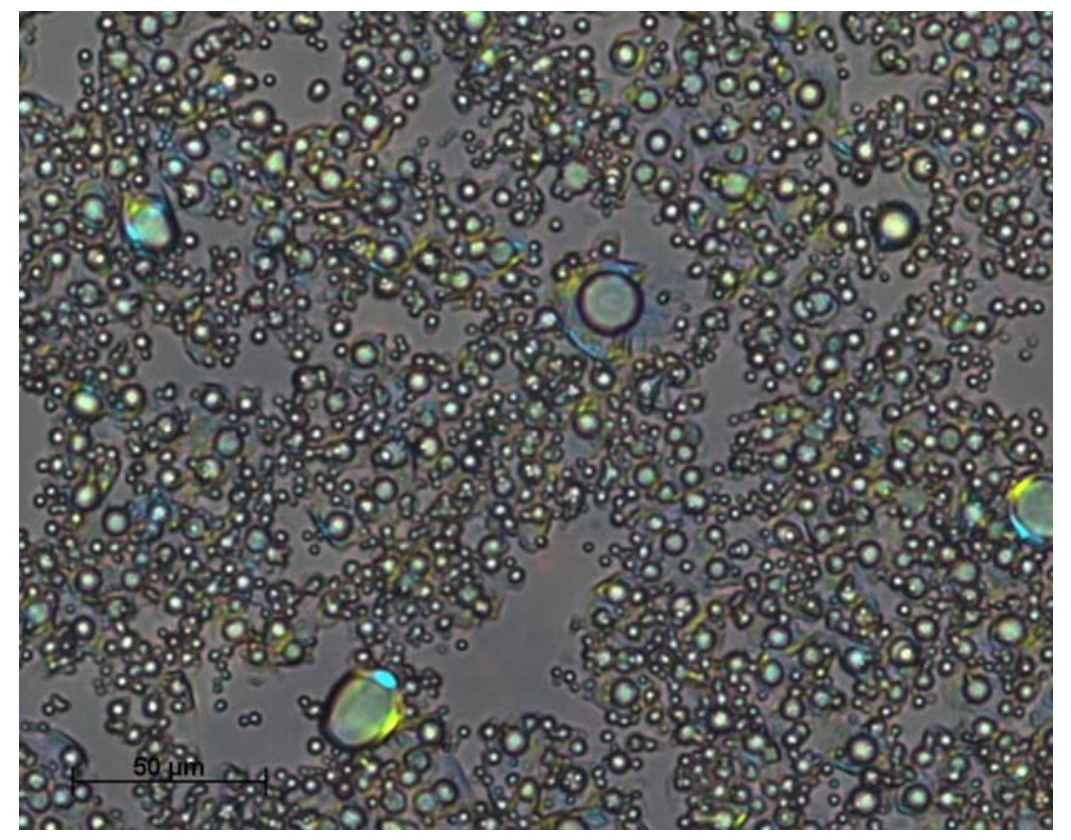

\section{(A) F3}

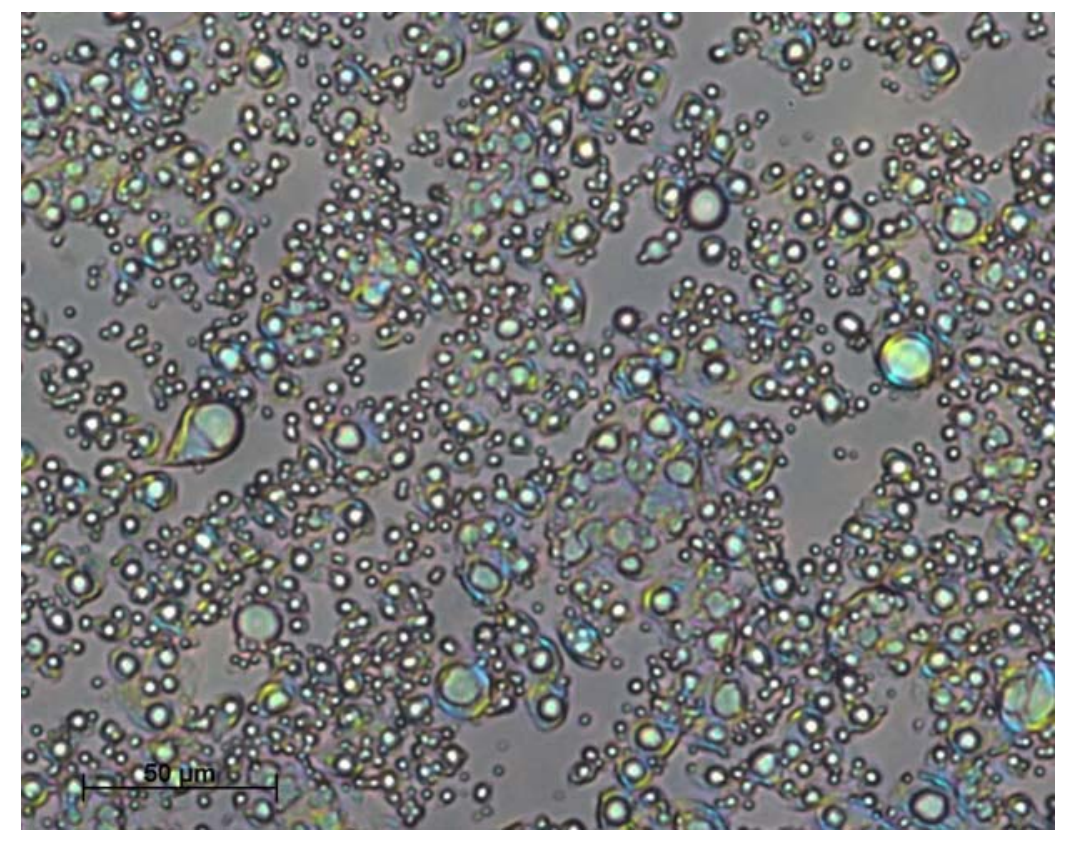

(B) F3A

Figura 60. Fotomicrografias sob luz polarizada das formulações A(F3) e B(F3A). 


\subsection{Método Cromatográfico}

\subsubsection{Construção da curva analítica do método cromatográfico e tratamento}

estatístico

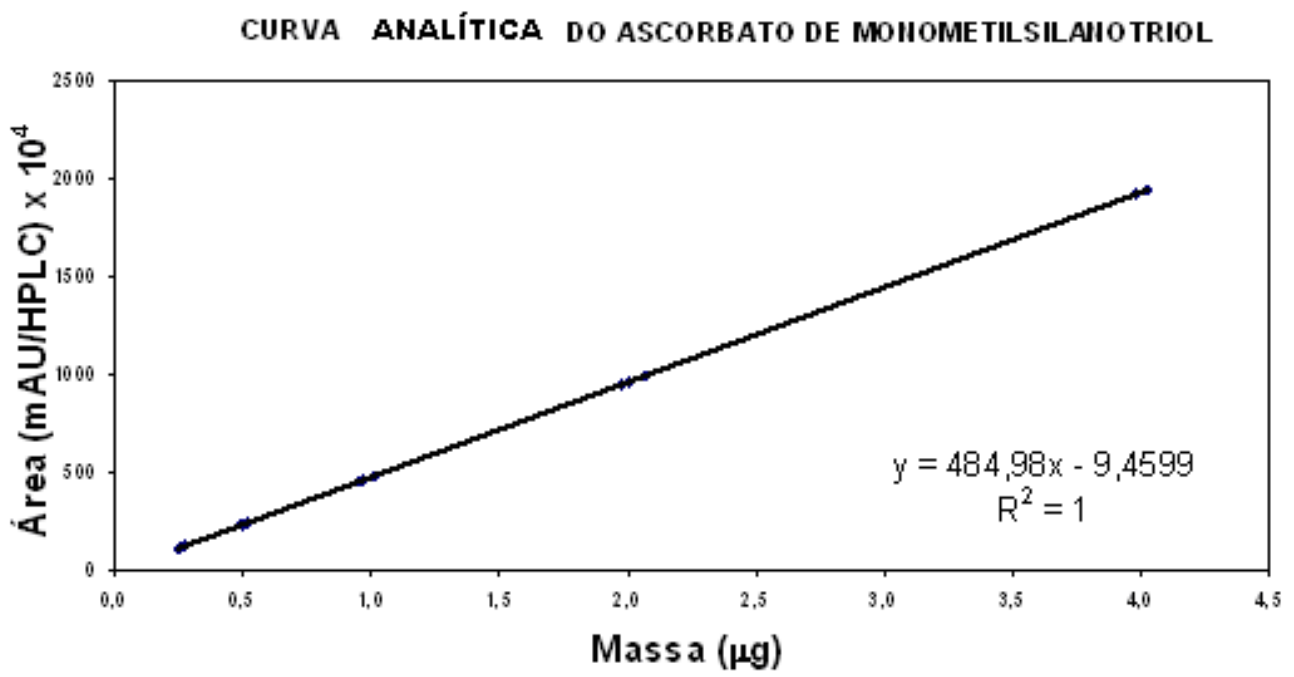

Figura 61. Curva de calibração obtida pelo método cromatográfico. 
Tabela 18. Análise estatística dos resultados obtidos na determinação da curva analítica do ascorbato de monometilsilanotriol (AMS) pelo método cromatográfico.

\begin{tabular}{|l|c|c|c|c|}
\hline Ascorbato de & a & b & r & DPR (\%) \\
monometilsilanotriol & & & & \\
\hline (AMS) & & & & \\
\hline & 484,98 & 9,4599 & 1 & 0,50 \\
\hline
\end{tabular}

a = intersecção da reta

b = inclinação da reta

r = coeficiente de correlação

$\mathrm{DPR}=$ desvio padrão relativo

\subsubsection{Pesquisa de interferentes (Seletividade)}

Não foi detectado nenhum pico que interferisse na determinação.

\subsubsection{Quantificação do teor de AMS nas formulações cosméticas obtidas (Precisão)}

A Tabela 19, mostra os resultados obtidos na determinação do teor de AMS nas formulações cosméticas obtidas. A pocentagem de DPR foi calculada para cada amostra, empregando-se 6 preparações independentes. A média do \% DPR obtido para as três amostras foi de $0,84 \%$, indicando uma boa repetibilidade do método. 
Tabela 19. Resultados das análises nas amostras F1A, F2A e F3A aplicando o método cromatográfico e o tratamento estatístico dos dados obtidos.

\begin{tabular}{llll}
\hline AMOSTRA & $\begin{array}{l}\text { Valores } \\
\text { Rotulados(\%) }\end{array}$ & $\begin{array}{l}\text { Valores } \\
\text { Encontrados (\%) }\end{array}$ & $\begin{array}{l}\text { Teor } \\
\text { (a) }\end{array}$ \\
& & & Percentual \\
& (DPR) \\
\hline F1A & 10 & 9,94 & $99,49(0,84 \%)$ \\
F2A & 10 & 10,04 & $100,41(0,82 \%)$ \\
F3A & 10 & 9,01 & $90,11(0,86 \%)$ \\
\hline
\end{tabular}

(a) Medida de 6 determinações.

\subsubsection{Exatidão (Recuperação)}

Tabela 20. Resultados obtidos na recuperação de solução padrão de AMS (solução aquosa à $1 \%$ ) adicionada as formulações cosméticas empregando o método cromatográfico.

\begin{tabular}{|c|c|c|c|}
\hline Amostra & $\begin{array}{c}\text { Quantidade de } \\
\text { padrão adicionado } \\
\text { ( } \mu \mathrm{g} / \mathrm{mL})\end{array}$ & $\begin{array}{c}\text { Quantidade de } \\
\text { padrão recuperado } \\
(\mu \mathrm{g} / \mathrm{mL})\end{array}$ & Recuperação (\%) \\
\hline \multirow[t]{3}{*}{ F1A } & 100,00 & 102,35 & 102,35 \\
\hline & 200,00 & 199,21 & 99,60 \\
\hline & 300,00 & 286,00 & 95,33 \\
\hline \multirow[t]{3}{*}{ F2A } & 100,00 & 99,69 & 99,69 \\
\hline & 200,00 & 209,96 & 104,84 \\
\hline & 300,00 & 288,12 & 96,04 \\
\hline \multirow[t]{3}{*}{ F3A } & 100,00 & 102,35 & 102,35 \\
\hline & 200,00 & 202,98 & 101,49 \\
\hline & 300,00 & 301,88 & 100,6 \\
\hline
\end{tabular}




\subsubsection{Limite de deteç̧ão e quantificação}

Os limites de detecção e quantificação obtidos foram respectivamente:

$0,084 \mu \mathrm{g} / \mathrm{mL}$ e $0,281 \mu \mathrm{g} / \mathrm{mL}$.

\subsubsection{Estabilidade da solução padrão}

De acordo com a avaliação, a solução padrão se mantém estável até 48 horas. Após esse período, o uso da solução não é recomendado. A Figura 55 mostra a avaliação da estabilidade da solução padrão submetida a congelamento e avaliada após $\mathrm{o}$ descongelamento. Sendo que a avaliação foi realizada logo após o descongelamento, 24 horas após e 48 horas após o descongelamento.

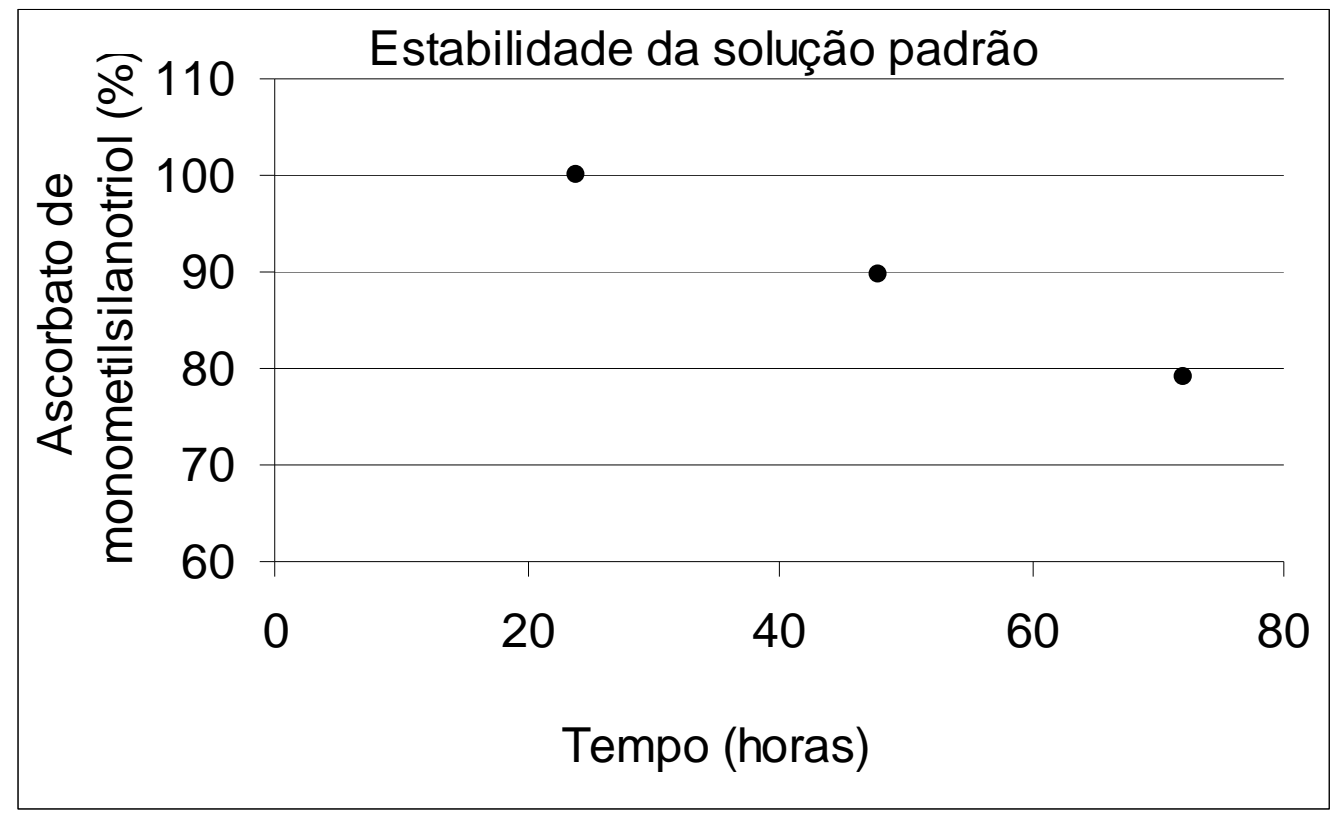

Figura 62. Gráfico da avaliação da estabilidade da solução padrão de AMS após sofrer descongelamento. 


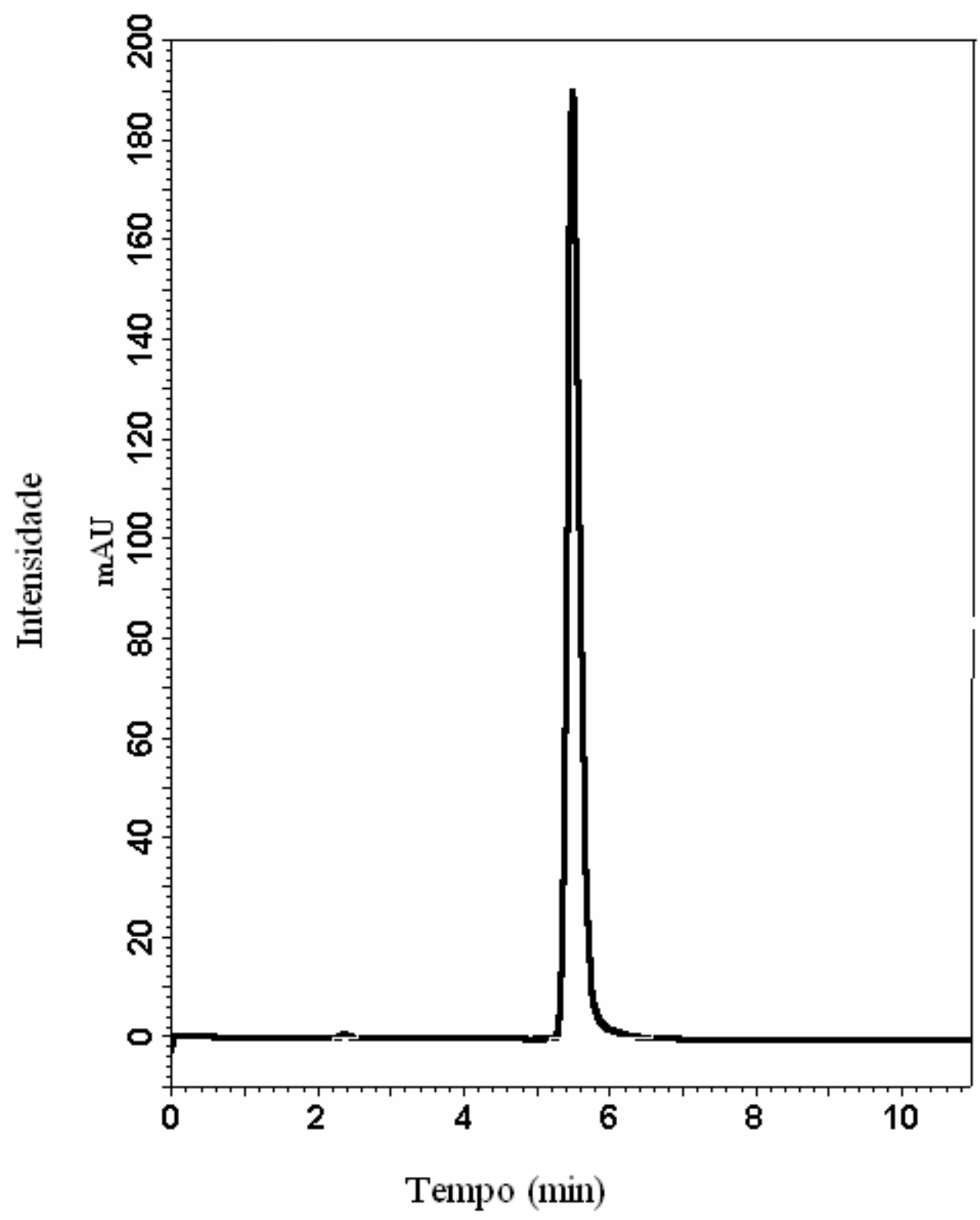

Figura 63. Cromatograma do ascorbato de monometilsilanotriol $(2,5 \mu \mathrm{g} / \mathrm{mL})$, obtido nas seguintes condições: coluna Synergi-Hydro ${ }^{\circledR}$ RP Phenomenex ${ }^{\circledR} 150$ X 4,6 mm, partícula de $4 \mu, 80 \AA$ de poro, C18, fase móvel: metanol:água $(30: 70 \mathrm{v} / \mathrm{v})+\mathrm{TBA} 30 \mathrm{mM}(\mathrm{pH}=5,94)$, vazão $1 \mathrm{~mL} / \mathrm{min}$, detecção a $254 \mathrm{~nm}$; temperatura ambiente. 


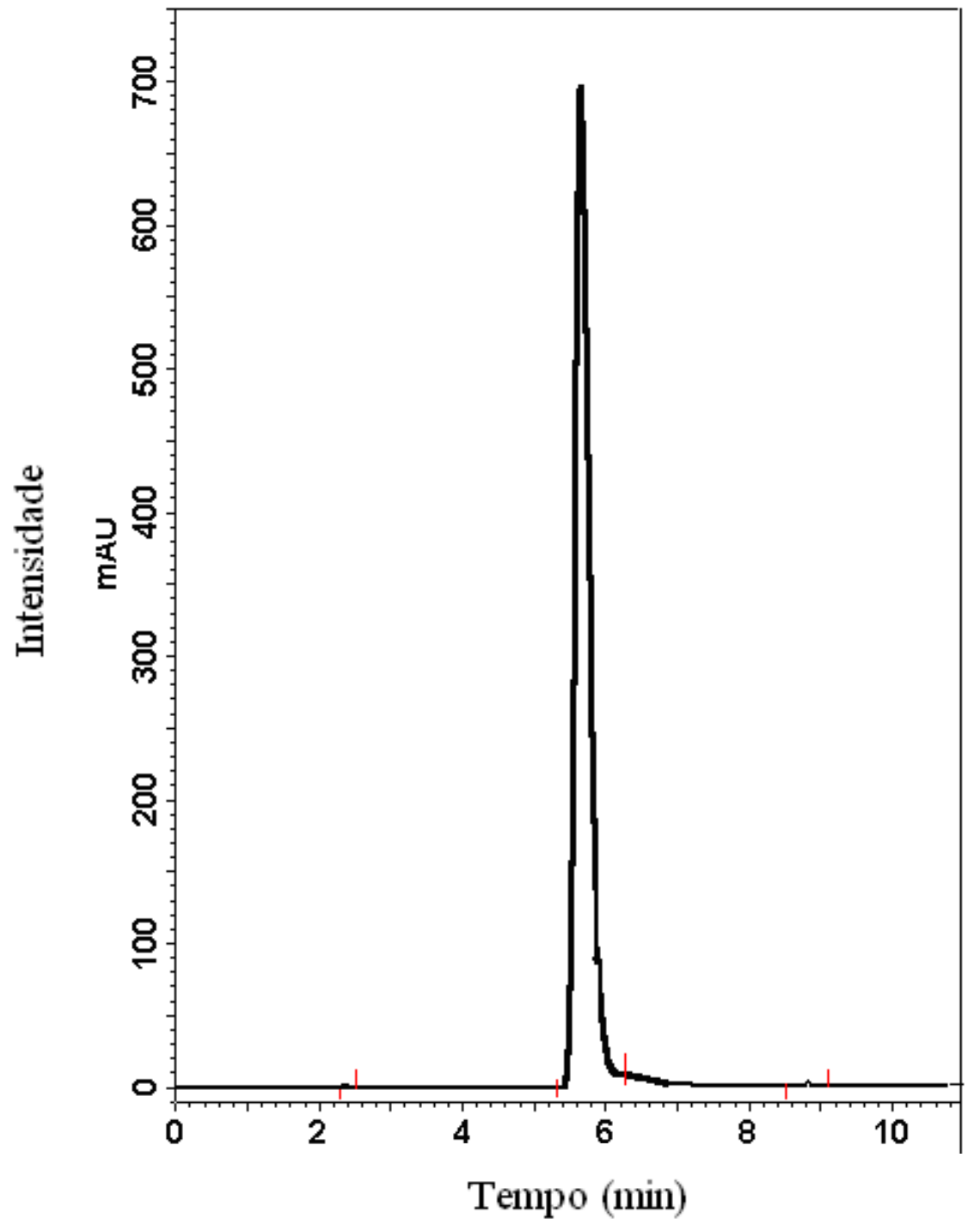

Figura 64. Cromatograma da formulação (F1A) $(45 \mu \mathrm{g} / \mathrm{mL})$, obtido nas seguintes condições: coluna Synergi-Hydro ${ }^{\circledR}$ RP Phenomenex ${ }^{\circledR} 150$ X 4,6 mm, partícula de $4 \mu, 80$ Å de poro, C18, fase móvel: metanol:água $(30: 70$ v/v)+TBA 30mM (pH = 5,94), vazão 1 $\mathrm{mL} / \mathrm{min}$, detecção a $254 \mathrm{~nm}$; temperatura ambiente. 


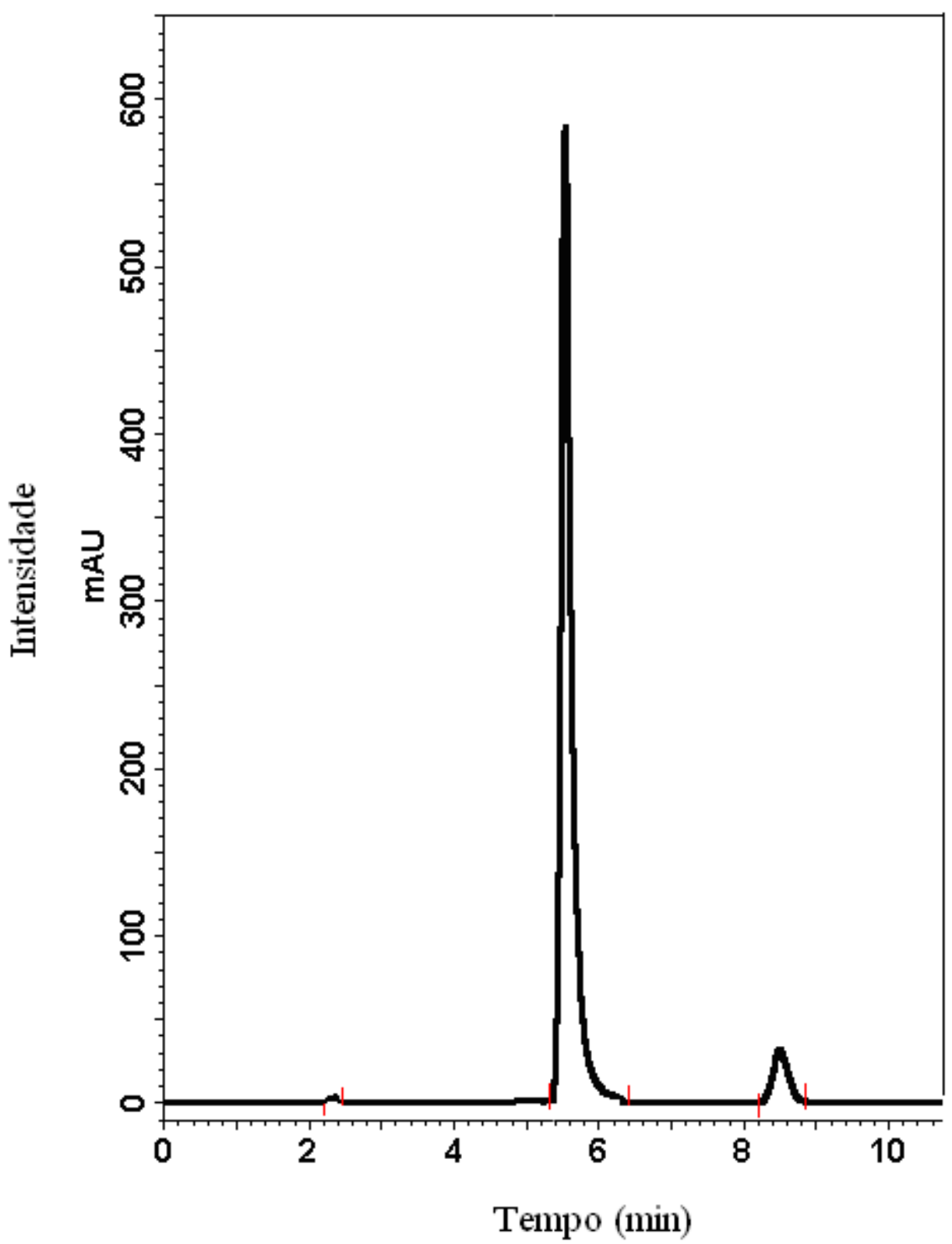

Figura 65. Cromatograma da formulação (F2A) $(4,5 \mu \mathrm{g} / \mathrm{mL})$, obtido nas seguintes condições: coluna Synergi-Hydro ${ }^{\circledR}$ RP Phenomenex ${ }^{\circledR} 150$ X 4,6 mm, partícula de $4 \mu, 80$ Å de poro, C18, fase móvel: metanol:água $(30: 70$ v/v)+TBA 30mM (pH = 5,94), vazão 1 $\mathrm{mL} / \mathrm{min}$, detecção a $254 \mathrm{~nm}$; temperatura ambiente. 


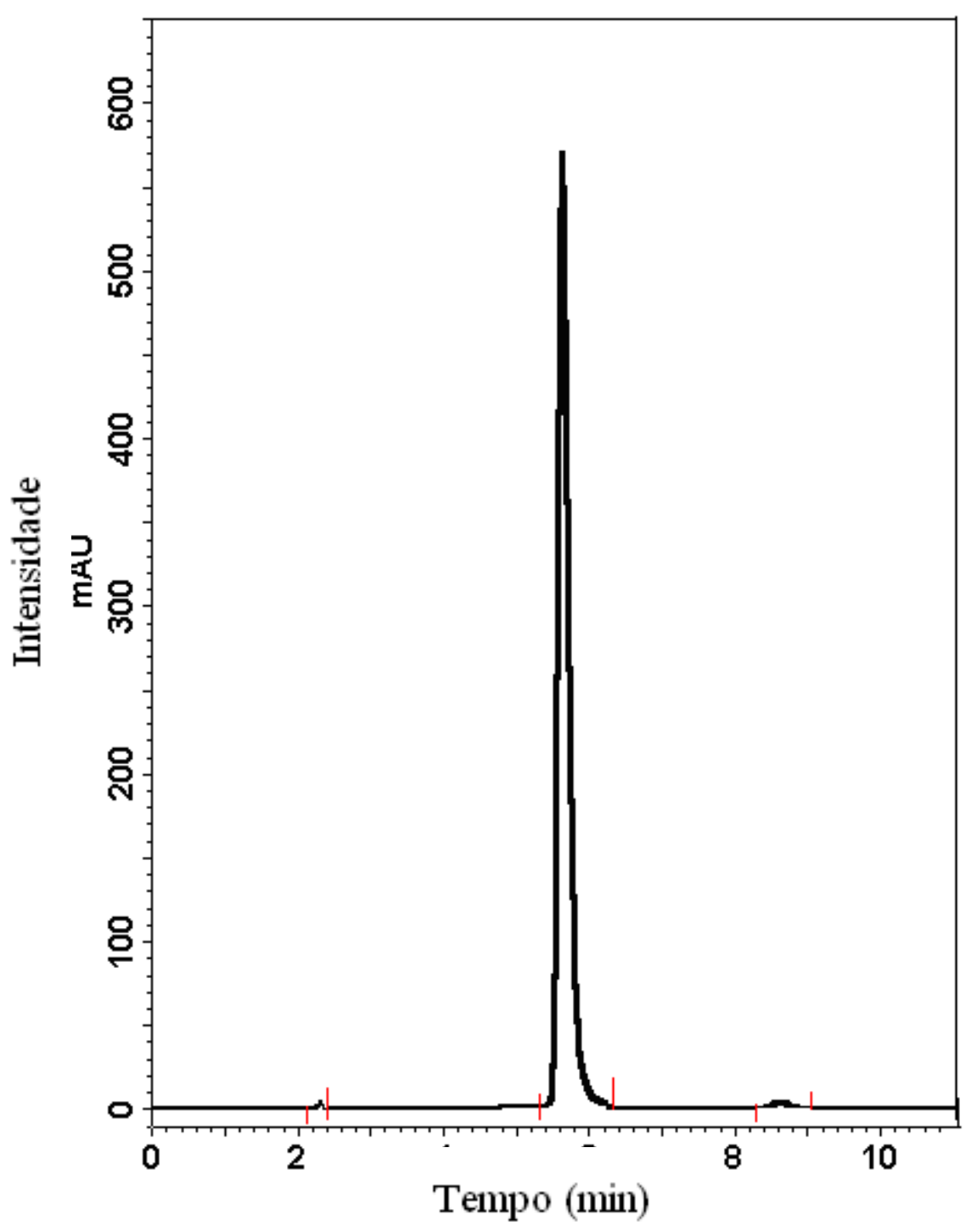

Figura 66. Cromatograma da formulação (F3A) $(4,5 \mu \mathrm{g} / \mathrm{mL})$, obtido nas seguintes condições: coluna Synergi-Hydro ${ }^{\circledR}$ RP Phenomenex ${ }^{\circledR} 150$ X 4,6 mm, partícula de $4 \mu, 80$ Å de poro, C18, fase móvel: metanol:água (30:70 v/v)+TBA 30mM (pH = 5,94), vazão 1 $\mathrm{mL} / \mathrm{min}$, detecção a $254 \mathrm{~nm}$; temperatura ambiente. 


\section{DISCUSSÃO}

O objetivo do presente trabalho foi caracterizar o ascorbato de monometilsilanotriol em formulações cosméticas.

Em relação às atividades cosméticas exercidas; o AMS agrega as propriedades cosméticas do AA à dos silanóis. A aplicação tópica do AMS aumenta a proteção proporcionada pelos mecanismos de defesa da pele, além de participar da biossíntese da hidroxiprolina (precursor do colágeno), proteoglicanas e carnitina. Por ser uma molécula estável e por apresentar tolerância cutânea e possuir atividade biológica acentuada, esse ativo é recomendado para a incorporação em produtos cosméticos, tais como, cremes, emulsões, leites e géis. Além de ser compatível com uma vasta gama de matérias primas e princípios ativos (POLYTECHNO, 2005; LEONARDI, 2004; EXSYMOL, 1998). No entanto, não foi estudada a avaliação do potencial antioxidante in vitro dessa molécula em trabalhos científicos.

Vários métodos analíticos para quantificação do ácido ascórbico e seus derivados foram relatados na revisão da literatura (MAIA et al, 2006; WANG \& WU, 2006; AUSTRIA, SEMENZATO \& BETTERO, 1997; SHIH \& KUANG, 2001), entretanto , até o presente momento, não conta na literatura o desenvolvimento de um método analítico para determinação do ascorbato de monometilsilanotriol em formulações cosméticas.

$\mathrm{O}$ trabalho experimental foi iniciado pela caracterização fisico-química do AMS (solução aquosa à 1\%), mediante emprego de métodos espectrofotométricos,cromatografia em camada delgada, perda por dessecação, termogravimetria (TG), calorimetria exploratória diferencial (DSC) e análise do tamanho de partícula empregando-se as técnicas de difração a laser e espalhamento dinâmico de luz. 
Ao ser analisado por espectrofotometria no ultravioleta, o espectro do AMS (solução aquosa à 1\%) apresentou pico máximo em 247 nm.

Os espectros na região do infravermelho do AMS apresentaram bandas de absorção na região de 4000 a $625 \mathrm{~cm}^{-1}$. O AMS apresenta em sua estrutura química, uma molécula de ácido ascórbico ligada a uma molécula de silanol. Pelo fato de conter ácido ascórbico acoplado a cadeia, apresenta bandas de absorção característica dessa molécula. O ascorbato de monometilsilanotriol, mostrou um estiramento de banda em função de -OH na região de 3243,14. Na região de 1644,54 apresentou uma banda característica de $\mathrm{C}=0$. A estrutura mostrou um estiramento da banda, característica da função SI-OH e deformação de banda na região de 760,70 em função de $-\mathrm{OH}$.

Os resultados obtidos por cromatografia em camada delgada (CCD) do AMS foram empregados para identificação da substância. O valor do Rf foi de 0,58.

A partir das condições experimentais utilizadas, a curva termogravimétrica do ascorbato de monometilsilanotriol (Figura 39), demonstrou perda de massa total a $100{ }^{\circ} \mathrm{C}$ .Para avaliar se a perda de massa era referente a água ou ao ativo propriamente dito, pelo fato desse apresentar-se comercialmente em solução aquosa à $1 \%$, os resultados forma confrontados com o método analítico de perda por dessecação. O resultado do teste sugere uma porcentagem de $1,8 \%$ de princípio ativo. De acordo com esse resultado, pode-se verificar claramente que a perda de massa é referente à evaporação da água e que a integridade do ativo na sua concentração descrita pelo fabricante encontra-se dentro dos parâmetros estabelecidos na literatura técnica.

A curva DSC obtida para o AMS (Figura 40) evidencia que a amostra é termicamente estável até a temperatura de $150{ }^{\circ} \mathrm{C}$. 
Pelo fato de o AMS apresentar-se em solução aquosa a 1\%, para caracterizar o ativo por calorimetria exploratória diferencial (DSC), empregou-se água destilada como padrão para o ensaio (Figura 44). Com base na curva DSC do ascorbato de monometilsilanotriol pode-se evidenciar claramente os processos de cristalização $(-13,5$ $\left.{ }^{\circ} \mathrm{C}\right)$ e fusão $\left(5,7^{\circ} \mathrm{C}\right)$, respectivamente.

A análise do tamanho de partícula do AMS foi executada empregando-se as técnicas de difração a laser e espalhamento dinâmico de luz. No entanto, o resultado da determinação de tamanho de partícula obtido pela técnica de difração à laser, não é confiável devido ao grande tamanho. O resultado obtido para o tamanho médio de distribuição das partículas foi de $34,36 \mu \mathrm{m}$ e, por isso, foi utilizada técnica de espalhamento dinâmico de luz. O tamanho grande obtido, deve-se a agregação das partículas do princípio ativo devido ao tipo de amostragem do aparelho. Pela análise de espalhamento dinâmico de luz, obteve-se um tamanho de aproximadamente $1 \mathrm{um}(919 \mathrm{~nm})$ e índice de polidispersidade de 0,111 . Os resultados podem ser visualizados na Tabela 7 e nas Figuras 45 e 46.

Com o objetivo de avaliar o potencial antioxidante in vitro do AMS foram empregados os métodos de determinação da atividade antioxidante pela reação com DPPH ( 2,2' -difenil-1-picrilhidrazil ) e determinação do potencial antioxidante por fluorescência - ORAC (Oxigen Radical Absorbance Capacity Assay). Os resultados obtidos com o teste por DPPH mostraram que o ascorbato de monometilsilanotriol apresenta as mesmas propriedades antioxidantes que o ácido ascórbico. Demonstrando que a presença de uma molécula de silanol acoplada a estrutura não alterou a atividade antioxidante do ácido ascórbico. Os resultados estatísticos obtidos na determinação da atividade antioxidante pela reação com DPPH ( 2,2'-difenil-1-picrilhidrazil ) estão nas Figuras 47 e 48 . O ácido 
ascórbico apresentou E50 de 6,65 $\mu \mathrm{g} / \mathrm{ml}$ e o AMS (solução aquosa à 1\%) apresentou EC50 de 5,92 $\mu \mathrm{g} / \mathrm{ml}$. Para verificar se a diferença entre os valores para AA e AMS foram significativos, foi aplicado o teste $\mathrm{t}$ de Student e de acordo com esse teste, $\mathrm{P}=0.1408$ não é considerado significante.

Em relação ao teste ORAC, o valor final, calculado com base na equação de regressão linear entre a concentração de $\operatorname{Trolox}^{\circledR}$ e a área sob a curva de decaimento de fluorescência (AUC) foi de 0,74. A Figura 49 mostra a avaliação estatística da determinação do potencial antioxidante do AMS obtido com base no ORAC. De acordo com, OU, WOODILL-HAMPSCH e PRIOR, 2001, o valor de ORAC para o ácido ascórbico é de 0,95 sendo próximo ao resultado obtido para o AMS.

A nova tendência em formulações cosméticas é a associação de um extrato botânico a vitaminas para aperfeiçoar o seu efeito na pele por efeitos sinérgicos (MAIA CAMPOS et al, 2006). Dessa forma no presente trabalho, as formulações cosméticas desenvolvidas apresentam em sua composição extratos e óleos vegetais de modo a potencializar o efeito do AMS.

As formulações obtidas foram submetidas a um teste preliminar de estabilidade. Os resultados dos testes preliminares de estabilidade das formulações por centrifugação mostram-se satisfatórios, visto que não houve separação de fases em nenhuma das formulações estudadas. 
Para verificar o tipo de emulsão de cada formulação, foi realizado um teste para determinação do tipo de emulsão (SANTOS, 2006). De acordo com os resultados (Tabela 9), as emulsões desenvolvidas podem ser classificadas como emulsões $\mathrm{O} / \mathrm{A}$.

Com a finalidade de avaliar a estabilidade das formulações desenvolvidas e comparar a estabilidade das formulações base (sem o ativo) com as formulações com ativo, um estudo de estabilidade acelerado foi conduzido. $\mathrm{O}$ estudo foi realizado por 90 dias, de acordo com recomendações do Guia de estabilidade de Produtos Cosméticos da ANVISA (BRASIL, 2004). As análises de avaliação dos caracteres organolépticos (cor, odor e aspecto), $\mathrm{pH}$ e viscosidade aparente foram realizadas nos $\mathrm{T} 0, \mathrm{~T} 1, \mathrm{~T} 7, \mathrm{~T} 15, \mathrm{~T} 30 \mathrm{e}$ T90. As condições de estresse empregadas foram: temperatura ambiente $\left(25^{\circ} \mathrm{C}\right), 5^{\circ} \mathrm{C}, 45^{\circ}$ $\mathrm{C}$ e fotoestabilidade à $25^{\circ} \mathrm{C}$.

Ao final dos 90 dias do estudo, a avaliação dos caracteres organolépticos revelou que apenas as formulações (com adição do ativo) submetidas à condição de estresse de fotoestabilidade à $25{ }^{\circ} \mathrm{C}$ apresentaram sinais visíveis de degradação, com desenvolvimento de coloração levemente amarelada. Comprovando assim, conforme o laudo do fabricante, a fotossensibilidade do ascorbato de monometilsilanotriol. As formulações armazenadas à temperatura ambiente $\left(25{ }^{\circ} \mathrm{C}\right), 45{ }^{\circ} \mathrm{C}$ e $5{ }^{\circ} \mathrm{C}$ mantiveram o aspecto, odor e coloração apresentada no início do estudo.

A análise de $\mathrm{pH}$ (Tabelas 10 a 16), não mostrou mudanças significativas para as formulações, nas 4 condições de armazenagem, quando se compara o $\mathrm{pH}$ no $\mathrm{T} 0$ e ao final do estudo (T90). A adição do AMS às formulações ocasionou o aumento de $\mathrm{pH}$ em todas nas condições de estresse avaliadas. 
Em relação à viscosidade aparente (Tabelas 10 a 16), não houve alterações relevantes para as formulações, nas 4 condições de armazenagem, quando se compara a viscosidade aparente no T0 e ao final do estudo (T90). Pode-se observar uma queda na viscosidade quando o princípio ativo é adicionado na formulação.

Considerando-se tais resultados é possível afirmar que as formulações desenvolvidas foram estáveis, pelo período de 90 dias, nas condições de estresse estabelecidas. No entanto, em relação às formulações contendo ascorbato de monometilsilanotriol, preconiza-se evitar a presença de luz.

As formulações foram avaliadas por calorimetria exploratória diferencial (DSC). As curvas DSC das formulações F1 e 1A (Figura 41), foram obtidas entre 25 e $150^{\circ} \mathrm{C}$ para avaliar a estabilidade térmica das formulações. Na curva referente à F1 (emulsão base sem incorporação de AMS), observa-se dois picos o primeiro representa a água fracamente ligada ao gel e o segundo pico a água interlamelar. Na curva que representa a formulação F1A (com adição do ativo), pode-se observar dois picos: ao primeiro sugere-se desidratação e ao segundo decomposição. Observa-se que o ativo ascorbato de monometilsilanotriol estabiliza a formulação, uma vez que a água fracamente ligada e a água interlamelar precisam de uma energia maior para serem deslocadas, conferindo ao gel maior estabilidade.

As curvas DSC das formulações F2, F2A, F3 e F3A (Figuras 42 e 43), apresentaram comportamento térmico similares. As curvas DSC apresentam perfis visivelmente diferentes entre ambas as formulações, com e sem ativo, e evidenciam que a adição do ativo nas mesmas, deslocam os eventos endotérmicos para temperaturas um pouco mais elevadas. 
As análises de tamanho de partícula das formulações foram realizadas com base na técnica de difração a laser. As formulações F1 e F1A, F2 e F2A apresentam distribuição do tamanho das partículas unimodal, os resultados podem ser observados nas Figuras 55 e 56. As formulações F3 e F3 A (Figura 57), apresentam distribuição do tamanho das partículas bimodal. É válido relatar que a adição do ativo às formulações não resultou em aumento significativo do tamanho de partícula das formulações estudadas.

Em relação às análises de microscopia de luz polarizada das formulações F1 e F2A, pode-se avaliar que ambas as formulações apresentam uma distribuição não homogênea, sendo evidenciada por duas populações, uma com tamanho maior e outra com tamanho menor. Dessa forma, os resultados de tamanho de partícula suportam os resultados da análise microscópica, no qual evidenciou-se formulações com distribuição não hogênea de gotículas de fase interna.

As análises de microscopia de luz polarizada das formulações F2 e F2a mostraram que a formulação sem ativo (F2) contém um número maior de gotículas de fase interna quando comparada a formulação com ativo (F2A). A incorporação de $10 \%$ do ativo (líquido hidrossolúvel) aumentou o volume de fase externa (aquosa) levando a uma redução na relação do volume de fase interna/fase externa como evidenciado na fotomicrografia (Figura 59) e também macroscopicamente pela redução da viscosidade.

Microscopicamente não foram observadas diferenças significativas entre as formulações F3 e F3A. Nas duas formulações, foram identificados cristais líquidos do tipo lamelar. Sendo que a incorporação do ativo a formulação não interferiu na formação de cristais líquidos. Em emulsões cosméticas, o tipo mais comum de cristal líquido encontrado é o liotrópico, com arranjo estrutural designado como lamelar. Essas fases lamelares são responsáveis pela estabilização das emulsões. Os cristais líquidos 
estabilizam a emulsão contra coalescência, mas não contra a floculação, sendo assim utilizados como promotores de estabilidade (SANTOS, 2006).

A cromatografia líquida de alta eficiência foi proposta para quantificação do AMS.

Sendo o AMS uma substância altamente polar, o modo reverso foi o adotado. Foi empregada para a execução do método uma coluna C18.

O método cromatográfico foi empregado utilizando detecção UV em $254 \mathrm{~nm}$. Foram testadas várias fases móveis sem adição de pareador iônico, no entanto não houve separação. Sendo assim, foram testadas várias fases móveis com diferentes concentrações do pareador iônico brometo de tetrabutilamônio. A fase móvel selecionada para a validação foi a que apresentou melhores resultados em termos de $\mathrm{K}$ (fator de capacidade) e tempo de retenção. A composição da fase móvel empregada foi : metanol:água (30:70 v/v) com adição de $30 \mathrm{mM}$ de TBA e pH de 5,9. O K foi de 1,8 e o tempo de retenção de aproximadamente 5 minutos.

Pelo fato de o ácido ascórbico apresentar valor de PKA 4,2 e ser a molécula ativa do AMS, há interação de atração por cargas opostas com o reagente de pareamento iônico (brometo de tetrabutilamônio), o qual está em solução que apresenta pH 5,9.

O tempo de corrida estabelecido de 10 minutos permitiu a eluição do ascorbato de monometilsilanotriol (tempo de retenção $=5,5$ minutos), tornando viável sua aplicação em análises de rotina. 
A curva analítica obtida por CLAE para o ascorbato de monometilsilanotriol (25 $\mu \mathrm{L}$ ) a $254 \mathrm{~nm}$ apresentou coeficiente de correlação (r) de 1, demonstrando boa linearidade do método (Figura 61 e Tabela 18).

Para pesquisa de interferentes foram preparadas amostras das formulações cosméticas obtidas de concentração final correspondente a $45 \mu \mathrm{g} / \mathrm{mL}$. Não foi detectado nenhum pico que interferisse na determinação, demonstrando uma boa seletividade para o método.

Os resultados obtidos na determinação do teor do AMS( Tabela 19) mostram que as formulações F1A, F2A e F3A apresentaram teor percentual de 99,49, 100, 41 e 90,11 respectivamente. O DPR(desvio padrão relativo) foi calculado para cada amostra, empregando-se 6 preparações independentes. A média do DPR(\%) obtido para as três amostras foi de $0,84 \%$, indicando uma boa repetibilidade do método e uma concordância entre os resultados obtidos.

Os percentuais de recuperação obtidos para as formulações cosméticas F1A, F2A, F3A mostraram-se satisfatórios (Tabela 20).

Os limites de detecção e quantificação foram respectivamente: $0,084 \mu \mathrm{g} / \mathrm{mL}$ e $0,281 \mu \mathrm{g} / \mathrm{mL}$.

Para avaliar a estabilidade da solução padrão de AMS, a solução foi congelada e, ao sofrer descongelamento foi analisada 24, 48 e 72 horas após atingir temperatura ambiente. De acordo com a análise, a solução se mantém estável até 48 horas. Após esse período, o uso da solução não é recomendado. A Figura 62 mostra a avaliação da 
estabilidade da solução padrão submetida a congelamento e avaliada após o descongelamento. 


\section{CONCLUSÕES}

A partir dos resultados experimentais pode-se concluir que :

O AMS pode ser caracterizado e identificado mediante emprego de diferentes métodos como: espectrofotometria no ultravioleta, espectrofotometria no infravermelho, cromatografia em camada delgada, perda por dessecação, termogravimetria (TG), calorimetria exploratória diferencial (DSC) e análise do tamanho de partícula.

O AMS pode ser caracterizado termicamente e, portanto, pode-se investigar a possibilidade de associar o comportamento térmico do ativo isolado com aquele da espécie incorporada em formulações. Os dados obtidos por análise térmica podem auxiliar na determinação da estabilidade física do princípio ativo e no desenvolvimento de formulações contendo esse ativo.

O AMS, apresentou tamanho de aproximadamente $1 \mathrm{um}(919 \mathrm{~nm})$ e índice de polidispersidade de 0,111 .

O AMS demonstrou ter propriedade antioxidante tão efetiva quanto o ácido ascórbico.

O valor de ORAC obtido para o AMS $(0,74)$ é próximo ao valor de ORAC para o ácido ascórbico $(0,95)$.

As formulações estudadas mantiveram suas características organolépticas, estabilidade física e não sofreram alterações relavantes em termos de $\mathrm{pH}$ e viscosidade aparente durabte o período de 90 dias. 
A metodologia desenvolvida para determinação do AMS demonstrou boa linearidade; precisão, limites de detecção e quantificação, podendo ser usada na análise de formulações cosméticas.

$\mathrm{O}$ ascorbato de monometilsilanotriol apresentou ser uma excelente alternativa como derivado do ácido ascórbico, por apresentar atividade antioxidante in vitro tão eficiente quanto à do ácido ascórbico e estabilidade superior em formulações cosméticas. 


\section{BIBLIOGRAFIA}

ABREU, L.R.P. Cromatografia em camada delgada. Disponível em:

http://labjeduardo.iq.unesp.br/orgexp. Acesso em: 15/06/2007.

ANSEL, H.C; POPOVICH, N.G; ALLEN, L.V. Farmacotécnica: formas farmacêuticas \& liberação de fármacos. São Paulo, Premier, p 299-310, 2000.

AUSTRIA, R; SEMENZATO, A; BETTERO, A.Stability of vitamin C derivatives in solution and topical formulations. Journal of Pharmaceutical and Biomedical Analysis, v.15, p 795-801, 1997.

BABY, A.R; MACIEL, C.P.M; ZAGUE, V; KANEKO, T.M; CONSIGLIERI, V.O; VELASCO, M.V.R. Estabilidade de Produtos de Aplicação Tópica. International Journal of Pharmaceutila Compounding, v.6, nº 3, p 130-139, 2004.

BARROS NETO, B; SCARMINIO, I.S; BRUNS, R.E. Como fazer experimentos: pesquisa e desenvolvimento na ciência e na indústria, $2^{\circ}$ ed., Campinas, SP: Editora da Unicamp, p. 64-70, 2003.

BARTHUS, R.C. Aplicação de métodos quimiométricos para análise de controle de qualidade de óleos vegetais utilizando espectroscopias no IV e Raman. Campinas, 89 p, 1999, (Dissertação de mestrado - Instituto de Química - UNICAMP).

BECKMANN COULTER. LS ${ }^{\text {TM }} 13320$ Series Laser Diffraction Particle Size Analyzer.

Disponível em:

http://www.beckmancoulter.com/products/instrument/partChar/pc 1s13320.asp. Acesso em: 10/06/2007.

BERARDESCA, E; MAIBACH, H. Pele étnica: avaliação da estrutura e função. J Am Acad Dermatol., p.1-4, 1996. 
BONINA, F; SAIJA, A; TOMAINO, A; LOCASCIO, R; RAPISARDA, P; DEDEREN, J.C. In vitro antioxidant activity and in vivo photoprotective effect of a red orange extract. International Journal of Cosmetic Science, v.20, p.331-342, 1998.

BRANCO, D. Atlas Eletrônico de Histologia. Disponível em: http://www.danielbranco.com.br/atlasi/092.html. Acesso em: 15/01/2007.

BRAND-WILLIAMS; CUVELIER, M.E ; BERSET,C. Use of free radical method to evaluate antioxidant activity. Lebensm.Wiss.u.technol, v.28, p. 25-30, 1995.

BRASIL. Ministério da Saúde. Resolução RDC n²11, de 14 de julho de 2005. Ficam estabelecidos a Definição e a Classificação de Produtos de Higiene Pessoal, Cosméticos e Perfumes, conforme Anexos I e II dessa Resolução. Disponível em:

http://e-legis.anvisa.gov.br. Acesso em: 20/01/2007.

BRASIL. Ministério da Saúde. Guia de Estabilidade de Produtos Cosméticos. Brasília: Ministério da Saúde, 47p, 2004 (Séries Temáticas).

BUENGER, J; ACKERMANN, H. et al. An interlaboratory comparison of methods used to assess antioxidant potentials. International Journal of Cosmetic Science, v.28, p. 135$146,2006$.

CARDOSO, T.M; RODRIGUES, P.O; STULZER, H.K; SILVA, M.A.S. Physicalchemical characterization and polymorphism determination of two nimodipine samples deriving from distinct laboratories. Drug development and Industrial Pharmacy. 31, p. 631-637,2005.

CHANG, M.L ; CHANG, C.M. Simultaneous voltammetric determination of ascorbic acid and its derivatives in cosmetics using epoxy-carbon composite electrodes. Journal of food and drug analysis, v. 13, p. 205-211, 2005. 
DAYER, J.R. Aplicações da espectrocopia de absorção aos compostos orgânicos. Edgard Blucher LTDA, São Paulo, p. 5-60, 1969.

DECCACHE, D. S. Formulação Dermocosmética contendo DMAE Glicolato e Filtros Solares: desenvolvimento de metodologia analítica, estudo de estabilidade e ensaio de biometria cutânea. Rio de Janeiro. 152p, 2006 (Tese de doutorado - Faculdade de Farmácia - UFRJ).

EXSYMOL. Ascorbosilane C .Technical Document. Monaco, 5p, 1998.

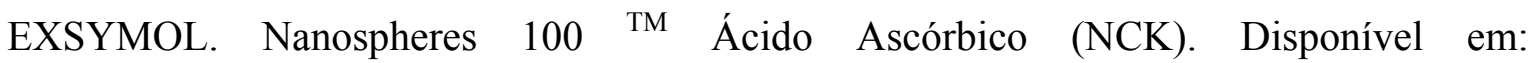
http:www.exsymol.com. Acesso em: 20/05/2006.

FORNARO, A; COICHEV, N. Ácido $L$-ascórbico: reações de complexação e de óxido redução com alguns íons metálicos de transição. Química Nova, v.21, nº 5, p.642-650. ISSN 0100-4042.

FONSECA,S. DMAE:A evolução do uso interno à cosmética. International Journal of Pharmaceutical Compounding. Edição Brasileira.v. 54, p.162, julho/agosto, 2003.

FRUCTUS, A. MONTET, F. LAZAR, G. Cosmetic and dermatological composition containing a derivative of methylated silanol and a derivative of hydrolysed plant protein, 2002. Available in: http://www.freepatentsonline.com/20020025303.html. Acesso em: $11 / 01 / 2007$.

GALLARATE, M; CARLOTTI, M.E; TROTTA, M; BOVO, S. On stability of ascorbic acid in emulsified systems for topical and cosmetic use. International Journal of Pharmaceuticals.v.188, p. 233-241 ,1999. 
GONÇALVES, S.M.F. Vitamina C na cosmecêutica. Revista Racine, ISSN 1807-166X, v. 64, p. 22-29,set/out, 2001.

GOVERNO DO RIO DE JANEIRO. Secretária de Saúde e Defesa Civil. Coordenação Estadual de Queimaduras do Estado do Rio de Janeiro. Estrutura da pele. Disponível em: http://www.saude.rj.gov.br/Queimaduras/estrutura pele.s.html. Acesso em: 08/06/2007.

GUILLEN, J.S.Q.; BATISTA, I.A.S.A.; MATOS, J.R.M. Contribuição da análise térmica na avaliação de princípios ativos empregados na prevenção do envelhecimento da pele isolados e/ou incoporados em geis e emulsões, Cosmetics \& Toiletries, v.18, ${ }^{\circ} 2$, p.50-52, 2006.

HAMEYER, P.; JENNI, K.R. Emulsifires for multiple Emulsions. Cosmetics \& Toiletries, v.111, n ${ }^{\text {o }}$, p.39, 1996.

HAYASHIBARA et al. AA2G stabilised vitamin C from Hayashibara. Disponível em: http:// hayashibara-intl.com/pdfs/AA2G.pdf . Acesso em 13/06/2007.

HERNANDEZ, M; FRESNEL, M.M.M. Manual de Cosmetologia. São Paulo: Revinter, p. 19-45, 1999.

INTERNATIONAL CONFERENCE ON HARMONIZATION- ICH. Instrumento: Validation of analytical procedures:text and methodology Q2(R1), novembro, 2005. Disponível em:http://www.ich.org. Acesso em 10/02/2007.

IGNÁCIO, R.F. Desenvolvimento de método de análise e estudo de estabilidade do ácido kójico associado ou não ao ácido glicólico em formulações tópicas. São Paulo, 228p, 2005 (Tese de doutorado - Faculdade de Ciências Farmacêuticas - USP).

ISHERWOOD, F.A; CHEN, Y.T; MAPSON, L.W. Synthesis of $L$-Ascorbic acid in Plants and Animals. The Biochemical Journal, v. 56, p. 1-15, 1954. 
KAMEYAMA, K; SAKAI, C; KONDOH, S; YONEMOTO, K; NISHIYAMA, S; TAGAWA, M; MURATA, T; OHNUMA, T; QUIGLEY, J; DORSKY, A; BUCKS, D; BLANOCK, K. Inhibitory effect of magnesium $L$-ascorbyl-2-phosphate (VC-PMG) on melanogenesis in vitro and in vivo. J Am Acad Dermatol, 34, p. 29-33, 1996.

KASZUBA, M; CONNAH, M; MATTISON, K. High concentration particle size measurements using dynamic light scattering. Lab Plus International, Malvern-UK, 2004.

KEDE, M.P.V., SABATOVICH, O. Dermatologia Estética. São Paulo: Atheneu, p.66, p.258-264, 2004.

LEONARDI, G. Cosmetologia Aplicada. São Paulo, Medfarma, p.234, 2004.

LOPEZ-TORRES, M;, THIELE, J.J., SHINDO, Y., HAN, D., PACKER, L. Topical application of $\alpha$-tocopherol modulates the antioxidant network and diminishes ultravioletinduced oxidative damage in murine skin. Br. J.Dermatol., Oxford, v.138, n.2, p.207-215, 1998.

MAIA, A.M; BABY, A.R; YASAKA, W.J; SUENAGA, E; KANEKO, T.M; VELASCO, M.V. Validation of HPLC stability-indicating method for Vitamin C in semisolid pharmaceutical/cosmetic preparations with glutathione and sodium metabisulfite, as antoxidants. Talanta, XXX, p.1-5, 2006.

MAIA CAMPOS, P.M.B.G; GIANETI, M.D; KANASHIRO, A; VALIM, Y.M.L; GASPAR, L.R. In Vitro Antioxidant and In Vivo Photoprotective Effects of an Association of Bioflavonoids with Liposoluble Vitamins. Photochemistry and Photobiology, v.82, p.683-688, 2006.

MAIA CAMPOS, P.M.B.G; SILVA, G.M. Ascorbic acid and its derivatives in cosmetic formulations. Cosmetics \& Toiletries International, v.115, p.59-62, 2000. 
MARTINS, S. Bioquímica e fisiologia da pele humana aplicados no desenvolvimento de formulações cosméticas. Apostila Racine Cosmetologia Express: desenvolvimento de produtos cosméticos. São Paulo, v.4, p.62-100, 2003.

MATOS, J. R; MACHADO, L.D.B. Introdução à Análise Térmica e Termogravimetria. (Cap. 11), Caracterização de Polímeros, Artliber Editora, p.209-228, São Paulo, Brasil, 2004.

MATSUMURA,Y; ANANTHASWAMY, H.N. Short-term and long-term cellular and molecular events following UV irradiation of skin: implications for molecular medicine.Disponível em: http://www.expertreviews.org. Acesso em: 15/04/2007.

MICRONAL. Dicas em Cromatografia Planar, junho 2004.Disponível em: http://www.micronal.com.br/artigostecnicos. Acesso em: 15/12/2007.

MONTAGNA, W.; KLIGMAN, A.M.; CARLISLE, K.S. Atlas of Normal Human Skin.Springer Verlag, New York, 1992.

MORGANTI, P; FABRIZI, G. New data on skin photoprotection International Journal of Cosmetic Science, v.22. p. 305-312, 2002.

MOSTEFA, N.M; SADOK, A.H; SABRI, N; HADJI. Determination of optimal cream formulation from long-term stability investigation using a surface response modeling. International Journal of Cosmetic Science, v.28, p. 211-218, 2006.

MOTHÉ, C.G.; CARESTIATO, T.; BUSNARDO, N.G.; GARRIDO, J. Estudo termoanalítico do creme anti-celulite à base de Gingko biloba, centella asiática e fucus vesiculosos. In: Congresso Brasileiro de Análise Térmica e Calorimetria, 5, Poços de Caldas, 2006. Livro de resumos. Poços de Caldas: ABRATEC, p.351, 2006. 
NARAYAN P., HANCOCK, B.C. The influence of particle size on the surface roughness of pharmaceutical excipient compacts, materials. Science and Engineering, v. 407, p.226$233,2005$.

NIKKOL. Oil soluble Vitamin C derivative. Technical Literature, Nikkol, 11p, 2002 [Catálogo].

NOGUEIRA, A.C.S. Efeito da radiação ultravioleta na cor, na perda protéica e nas propriedades mecânicas do cabelo (Dissertação de mestrado - Unicamp). p. 3-5, 2002.

OLIVEIRA, I.O; ALMEIDA, H.L.Jr. Current knowledge on the biology of melanocytes in the human hair follicle. An Bras. Dermatol, 78(3), p. 331-343, maio/jun, 2003.

OBAGI, Z.E. Anatomia e fisiologia da pele: uma visão Pessoal. Rio de Janeiro: Revinter, p. 13-22, 2004.

ORIÁ, B. R et al. Estudo das alterações relacionadas com a idade na pele humana, utilizando métodos de histo-morfometria e autofluorescência. An Bras Dermatol, Rio de Janeiro, 78(4). p. 425-434, jul/ago, 2003.

OU, B; WOODILL-HAMPSCH, M; PRIOR, R.L. Development and Validation of na Improved Oxygen Radical Absorbance Capacity Assay Using Fluorecein as the Fluorescent Probe. J.Agric.Food.Chem, v.49, p.4619-4626, 2001.

ÖZER, Ö; BALOGLU, E; ERTAN, G; MUGUET, V; YAZAN, Y. The effect of type and the concentration of the lipophilic surfactant on the stability and release kinetics of $\mathrm{W} / \mathrm{O} / \mathrm{W}$ multiple emulsions. International Journal of Cosmetic Science, v.22, p.459-470, 2000. 
PAPINI, C.J. Estudo comparativo de métodos de determinação do tamanho de partícula. São Paulo, Instituto de pesquisas energéticas e nucleares - USP, mestrado, 130 p, 2002.

PECORA, R. Dynamic Light Scattering. ISBN 0306417901, Springer, 436p, 1985.

PERES, T.B. Noções Básicas de Cromatografia. Biológico, v.64, nº2, p. 227 - 229, São Pualo, 2002,

POLYTECHNO. Ascorbosilane C. Literatura Técnica. 4p, 2005.

RANGEL, V.L.B.I., BOSCHETTI, V.C; UEMA, M.K. Determinação do prazo de validade do ácido glicólico incorporado em uma emulsão não iônica. International Journal of Pharmaceuticla Compounding, v.6, n³, p. 140-145, 2004.

RAWLE, A. Basic principles of particle- size analysis. A surface Coatings International A. vol.86, n.AO2, pp. 58-65, 2003.

RIBEIRO, C. J. Cosmetologia Aplicada a Dermoestética. $1^{\text {a }}$ ed. São Paulo: Pharmabooks, 2006.

RIBEIRO, C., OHARA, M.T. Hiperpigmentação localizada na pele: manifestação inestética que exige cuidados. Revista Racine, São Paulo v.67, ano XII, n.1, p.62-66, 2002.

RODRIGUES, P.O; CARDOSO, T.F.M; SILVA, M.A.S; MATOS, J.R.M. Aplicação de técnicas termoanalíticas na caracterização, determinação da pureza e cinética de degradação da zidovudina (AZT). Acta Farm.Bonarense, v.24 nº3, p. 383-387, 2005.

ROPKE, C.D; MEIRELLES, R.R; SILVA, V.V; SAWADA, T.C.H; BARROS, S.B.M. Pothomorphe umbellata Extract Prevents a Tocopherol Depletion After UV-irradiation. Photochemistry and Photobiology . v.78(5), p. 436-439, 2003.

SANTOS, O.D.H. Desenvolvimento e avaliação das propriedades físico-químicas e atividade cosmética in vivo de emulsões de óleo de Calendula officinalis com cristal 
líquido. Ribeirão Preto, Faculdade de Ciências Farmacêuticas de Ribeirão Preto-USP, doutorado, 133p, 2006.

\section{SCOTTI, L.; VELASCO M. V. R. Envelhecimento cutâneo à luz da cosmetologia.}

São Paulo: Tecnopress, p. 12-108, 2003.

SCOTTI, L. Estudo do envelhecimento cutâneo e da eficácia cosmética de substâncias ativas empregadas em combatê-lo. São Paulo, Faculdade de Ciências Farmacêuticas USP, mestrado, p. 1-160, 2002.

SHIMADZU. Analisador térmico. Disponível em:

http://www.shimadzu.com.br/analitica/produtos/analisadores/ta/tga.aspx. $\quad$ Acesso em: $15 / 06 / 2007$

SEMENZATO, A; AUSTRIA, C; DALl'AGLIO,C; BETTERO, A. High-performance liquid chromatographic determination of ionic compounds in cosmetic emulsions: application to magneisum ascorbyl phosphate. Journal of Chromatography A, v.705, p. 385-389, 1995.

SHIH, Y; KUANG, H. Simultaneous Determination of Magnesium L-Ascorbyl-2Phosphate and Kojic Acid in Cosmetic Bleaching Products by Using a Microbore Column and Ion-Pair Liquid Chromatography. Journal of AOAC International International, v.84, nº 4 , p. 1045-1049,2001.

SILVA, E.C. Desenvolvimento e avaliação da estabilidade de formulações contendo arbutina, associada ou não ao ácido glicólico. Faculdade de Ciências Farmacêuticas - USP, mestrado, São Paulo, p 1-181, 1998.

SILVA, E.C; SOARES, I.C. Tecnologia de Emulsões. Cosmetics and Toiletries (Edição em Português), v.8, p.37-45, 1996. 
SILVA, G.M; MAIA CAMPOS, P.M.B.G. Histopathological, morphometric and steriological studies of ascorbic acid and magnesium ascorbyl phosphate in a skin care formulation. International Journal of Cosmetic Science, v.22, p. 169-179, 2000.

SILVA, G.M; MAIA CAMPOS, P.M.B.G. Influence of a Formulation`s on Cutaneous Absorption of Ascorbic Acid. Cosmetic \& Toiletries International, v.116, p. 73-75, jan, 2001 .

SILVA, M.A.S; KELMANN, R.G; FOPPA, T; CRUZ, A.P; BERTOL, C.D; SARTORI, T; GRANADA, A; CARMIGNAN, F; MURAKAMI, F.S. Thermal analytical study of fluoxitine hydrochloride. Journal of Thermal Analysis and Calorimetry.v.87, p. 463467, 2007.

SILVA, M.A.S. Análise da influência do teor de água em cremes O/A por espalhamento de raios-X em baixos ângulos, microscopia eletrônica de transmissão e análise térmica. São Paulo, Faculdade de Ciências Farmacêuticas - USP, mestrado,73 p, 1995.

SIMÊNCIO, E. C. A; YARIWAKE, J.H. Análise por cromatografia em camada delgada (CCD) de herbicidas triazínicos na cana de açúcar e em seus derivados. 29a Reunião Anual da Sociedade Brasileira de Química (SBQ), Águas de Lindóia, 2006 Livro de resumos. Ref. QA-166.

SNYDER, L.R; KIRKLEND, J.J ; GLAJCH, J.L. Practical HPLC method development, 2 ed. New York: Wiley Interscience, 765p, 1996.

SPICLIN, P; GASPERLIN, M and KMETEC, V. Stability of ascorbyl palmitate in topical microemulsions. International Journal of Pharmaceuticals. v.222, p.271-279, 2001.

SWARTZ, M.E.; KRULL, I.S. Validação de métodos cromatográficos. Pharm. Technol, São Paulo, v.2, n. 3,p.12-20, 1998. 
SVIRBELY, J.L; SZENT GYÖRGYI, A. The chemical nature of vitamin C. The Biochemical Journal, v. XXVII, nº 1, p. 279-285, 1933.

TAGAWA, M; UJI, K.; TABATA, Y. The application of magnesium ascorbate phosphate to skin care cosmetics. In: XV IFSCC CONGRESS, v.3, p. 399-414, 1988.

THIBODEAUS, A. Controle das MMPs Durante o Branqueamento da Pele. Cosmetic \& Toiletries. São Paulo, ISSN 0103-4030, v.16, n.4, p.72-74, 2004.

THOMAS, M.J. The Role of Free Radicals and Antioxidants. Nutrition. v.16, $\mathrm{n}^{\mathrm{0}}$ 7/8, p. 716-718, 2000.

THORMAHLEN, S. Vitamins in cosmetic formulations. A new generation of products. In IFSCC International Congress XXI ${ }^{\text {st }}$, p. 459-467 (2000).

Universidade Federal do Pará. Classificação de métodos de medida ou comparação de cor. Disponível em: http://www.ufpa.br/ccen/quimica/classificacao\%20metodos.htm. Acesso em: 14/06/2007.

UNITED STATES PHARMACOPEIA, 30.ed. Rockville: The United States Pharmacopeial Covention, 2007.

VASCONCELLOS, H. Como escolher um analisador de tamanho de partículas. Disponível em: http://www.instrutec.com.br/produtos/particulas/Difracao.html. Acesso em: 10/06/2007.

VESLASQUEZ -ARMIJO, C.J; COSTA, I.M; LONGHINI, R; PETZHOLD, C.L; PETROVICK, P. Métodos termo-analíticos e suas aplicações nas ciências farmacêuticas. Caderno de farmácia, ISSN 0102-6593, v.20, nº 1, p. 29 - 47, 2004.

WAKO-CHEM. Ascorbic Acid 2-Glucoside. Disponível em: 
http://www.wako-chem.co.jp/siyaku/info/life/article/vc_2-glu.htm. Acesso em: $13 / 06 / 2007$.

WANG, C.C; WU, S.M. Simultaneous determination of $L$-ascorbic acid-2-phosphate magnesium salt,a nd ascorbic acid-6-palmitate in commercial cosmetics by micellar eletrokinetic capillary eletrophoresis. Analytica Chimica Acta, XXX ,6p, 2006.

WESTON, A.; BROWN, P.R. HPLC and CG: principles and practice. San Diego: Academic Press, 1997, 280p.

WIKIPEDIA.Ascorbic Acid.Disponível em:http://en.wikipedia.org/wiki/Ascorbic_acid. Acesso em : 10/06/2007.

WILKINSON, J.B. MOORE, R.J. A Cosmetologiá de Harry. Editora: Diaz de Santos, p.295-300, 1990. 